cidade, corpo e alimentaç̃̃o 


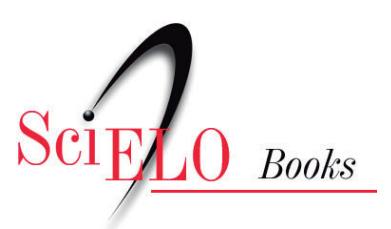

\title{
Cidade, corpo e alimentação aproximações interdisciplinares
}

\author{
Maria Lúcia Magalhães Bosi \\ Shirley Donizete Prado \\ Ligia Amparo-Santos \\ (orgs.)
}

BOSI, M.L.M., PRADO, S.D., And AMPARO-SANTOS, A., comps. Cidade, corpo e alimentação: aproximações interdisciplinares [online]. Salvador: EDUFBA, 2019, 284 p. ISBN: 978-65-5630-010-8. https://doi.org/10.7476/9786556300108.

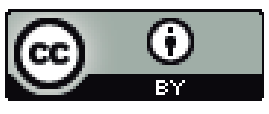

All the contents of this work, except where otherwise noted, is licensed under a Creative Commons Attribution 4.0 $\underline{\text { International license. }}$

Todo o conteúdo deste trabalho, exceto quando houver ressalva, é publicado sob a licença Creative Commons Atribição $\underline{4.0}$.

Todo el contenido de esta obra, excepto donde se indique lo contrario, está bajo licencia de la licencia Creative Commons Reconocimento 4.0. 
cidade, corpo e alimentação 
UNIVERSIDADE FEDERAL DA BAHIA

Reitor João Carlos Salles Pires da Silva

Vice-Reitor Paulo Cesar Miguez de Oliveira

Assessor do Reitor Paulo Costa Lima

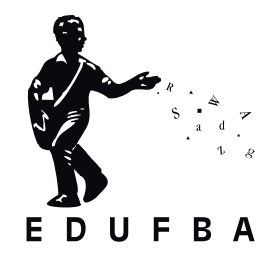

EDITORA DA UNIVERSIDADE FEDERAL DA BAHIA

Diretora

Flávia Goulart Mota Garcia Rosa

Conselho Editorial

Alberto Brum Novaes

Angelo Szaniecki Perret Serpa

Caiuby Alves da Costa

Charbel Ninõ El-Hani

Cleise Furtado Mendes

Evelina de Carvalho Sá Hoisel

José Teixeira Cavalcante Filho

Maria do Carmo Soares de Freitas

Maria Vidal de Negreiros Camargo 
cidade,

corpo e

alimentaç̃o

$=$

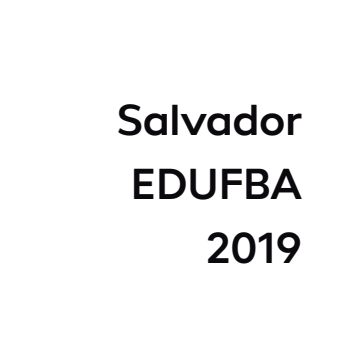


2019, autores

Direitos para esta edição cedidos à Edufba.

Feito o Depósito Legal.

Grafia atualizada conforme o Acordo Ortográfico da Língua Portuguesa

de 1990, em vigor no Brasil desde 2009.

\section{Capa e Projeto Gráfico}

Gabriel Cayres

Revisão

Juliana Lopes Roeder

\section{Normalização}

Cecília Nascimento

SISTEMA DE BIBLIOTECAS - UFBA

Cidade, corpo e alimentação : aproximações interdisciplinares / Maria Lúcia Magalhães Bosi, Shirley Donizete Prado e Ligia Amparo-

Santos, organizadoras. - Salvador : EDUFBA, 2019.

$284 \mathrm{p}$.

Rede Ibero-americana de Pesquisa Qualitativa em Alimentação e Sociedade. ISBN 978-85-232-1915-4

1. Nutrição - aspectos sociais. 2. Corpo humano - Aspectos sociais. 3. Hábitos alimentares. I. Bosi, Maria Lúcia Magalhães. II. Prado, Shirley Donizete. III. Santos, Ligia Amparo da Silva.

CDD - 641.3

Evandro Ramos dos Santos - CRB-5/1205

Editora afiliada à
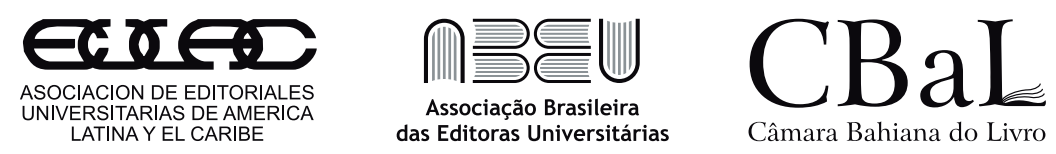

Editora da UFBA

Rua Barão de Jeremoabo

s/n - Campus de Ondina

40170-115 - Salvador - Bahia

Tel.: +55 71 3283-6164

www.edufba.ufba.br

edufba@ufba.br 
Esta coletânea foi organizada por

\section{REDE NAUS}

Rede Ibero-americana de Pesquisa Qualitativa

em Alimentação e Sociedade

Em parceria com

\section{LAPQS}

Laboratório de Avaliação e Pesquisa Qualitativa em Saúde Faculdade de Medicina

Universidade Federal do Ceará (UFC)

\section{NECTAR}

Núcleo de Estudos sobre Cultura e Alimentação

Instituto de Nutrição

Universidade do Estado do Rio de Janeiro (UERJ)

\section{NEPAC}

Núcleo de Estudos e Pesquisas em Alimentação e Cultura

Escola da Nutrição

Universidade Federal da Bahia (UFBA) 


\section{Sumário}

9 Apresentação

Shirley Donizete Prado e Ligia Amparo-Santos

21 Prefácio

Luis Antonio dos Santos Baptista

35 Introdução

Maria Lúcia Magalhães Bosi

49 CAPÍTULO 1

Arte na cidade: inspirações

para os campos da saúde e alimentação

Maria Lúcia Magalhães Bosi e Isabela Magalhães Bosi

69 CAPÍTULO 2

Feminismos e agroecologia:

lutas contemporâneas na cidade

Maria da Graça Costa, Magda Dimenstein e Jáder Ferreira Leite

99 CAPÍTULO 3

De mercado à vila: práticas alimentares e higiene frente ao processo de gentrificação na cidade de Salvador, Bahia

Diego Marinho Calabrese e Ligia Amparo-Santos

119 CAPÍTULO 4

Corpo, identidade, cultura e risco:

reflexões sobre o excesso de peso em contexto urbano

Tatiana Coura Oliveira, Dina Czeresnia e Eliane Portes Vargas 
153 CAPÍTULO 5

Sociabilidade e alimentação: um estudo

sobre arranjos simbólicos em grandes centros urbanos

Christiane Ayumi Kuwae, Francisco Romão Ferreira,

Maria Cláudia da Veiga Soares de Carvalho, Shirley Donizete Prado

e Luisa Ferreira da Silva

177 CAPÍTULO 6

Corpo, comida e rua:

interfaces produzidas na cidade

Diana Cris Macedo Rodrigues e Ligia Amparo-Santos

205 CAPÍTULO 7

Le style veggie: comment l'ascétisme

est-il devenu cool

Marianne Celka

217 CAPÍTULO 8

Comidas e cidades: múltiplas apropriações

do consumo alimentar na mídia

Daniela Menezes Neiva Barcellos, Igor Sacramento, Maria Cláudia da

Veiga Soares Carvalho e Ricardo Ferreira Freitas

239 CAPÍTULO 9

Comida de rua: corpo, emoções

e etnocentrismo na cidade

Denise da Costa Oliveira Siqueira

257 CAPÍTULO 10

Itinerarios alimentarios en contextos de precarización: otras formas de comer, otras formas de vivir

Mabel Gracia Arnaiz

279 Sobre os autores 


\section{Cidade-alimentação aproximações interdisciplinares}

SHIRLEY DONIZETE PRADO E LIGIA AMPARO-SANTOS

A presente coletânea resulta de parceria entre o Laboratório de Avaliação e Pesquisa Qualitativa em Saúde (LAPQS) da Faculdade de Medicina da Universidade Federal do Ceará (UFC), o Núcleo de Estudos e Pesquisas em Alimentação e Cultura (Nepac) da Escola da Nutrição da Universidade Federal da Bahia (UFBA) e o Núcleo de Estudos sobre Cultura e Alimentação (Nectar). Corresponde à segunda iniciativa da Rede Ibero-americana de Pesquisa Qualitativa em Alimentação e Sociedade (Rede Naus) ${ }^{1}$ em matéria de publicações, que, assim, se consolida como uma via por onde fluem conhecimentos, construindo

1 A primeira coletânea publicada pela Rede Naus intitulada Estudos socioculturais em alimentação e saúde: saberes em rede. Disponível em: http://books.scielo.org/search/?lang=pt\&ind ex=tw\&where=BOOK\&q=shirley\&filter\%5Bpublisher\%5D\%5B\%5D=EDUERJ. 
cooperação acadêmica e firmando a liberdade para criação humana como referência central. Materializamos, por esse caminho, o compartilhamento de uma visão crítica em relação à ciência e ao fazer científico, tomando a pesquisa qualitativa como práxis na formação de pesquisadores, na produção de saberes e, também, como movimento que opera no sentido da construção de uma ciência comprometida com valores éticos e justiça social. Nesse trilhar, confiamos no fortalecimento da pesquisa qualitativa e na internacionalização desse conhecimento, ainda que mantida a percepção de um cenário complexo em suas possibilidades e adversidades quando se parte do campo da alimentação e nutrição em busca de diálogos com as Humanidades.

Desta feita, a presente obra reúne escritos sobre corpo e alimentação que, por caminhos diversos, estão considerando a cidade como categoria relevante para o desenvolvimento de análises em face de diversas questões, entre as quais as que estão aqui abordadas. Ao convidar os autores a trazer à tona o tema das cidades nos estudos do campo da alimentação, cultura e sociedades, nosso objetivo foi tomar essa categoria como ponto de partida para pensar em uma nova possibilidade de abordagem teórico-metodológica nesta teia de saberes.

Tal movimento nasceu de uma perspectiva inicial que dizia respeito a estudos sobre alimentação e nutrição na contemporaneidade, percebendo-os orientados pelas transformações sociais ocorridas no interior de intenso processo de urbanização e industrialização ao longo do século XX e das primeiras décadas do século XXI. Considerávamos que a cidade estaria pouco abordada no campo como problema a ser tomado para discussão quando se busca tratar de alimentação, corpo e subjetividades.

Para melhor ilustrar essas percepções originais, tomamos como base alguns elementos presentes em estudos publicados na Revista de Nutrição, único periódico científico brasileiro inserido nas bases de indexação internacionais consideradas prestigiosas no âmbito das principais agências de pesquisas - como as que compõem a Clarivate Analytics estritamente destinado à divulgação de trabalhos do campo alimentar-nutricional. A Revista de Nutrição foi admitida na coleção da Scientific 
Electronic Library Online (SciELO) em 1997, quando levou aos leitores um número com cerca de seis textos. Chega a 2018, divulgando quatro números por ano com cerca de dez artigos em cada um desses fascículos. Seu tom hegemonicamente biomédico pode ser considerado bastante representativo do campo brasileiro da nutrição, no qual vicejam estudos de cunho clínico e epidemiológico acompanhados de abordagens normativas em suas tendências a homogeneizar a vida humana idealizadamente apartada de doenças, agravos à saúde e sofrimentos em geral. Adensam-se aqui as expressões dos estudos quantitativos que abrem fenômenos sociais em variáveis de risco e fatores determinantes de desfechos nutricionais.

Antes, porém, de apresentar esses achados, uma importante ressalva precisa ser feita. É necessário registrar que, na Revista de Nutrição, tem havido lugar para publicação de estudos socioculturais e de caráter humanístico, mesmo que poucos. Nessa perspectiva, também é preciso falar da existência de publicações em outras revistas que estão situadas ou que guardam afinidades com os campos da Comunicação, Antropologia, Sociologia, Filosofia, Psicologia, enfim, aqueles que se dedicam à compreensão das relações humanas para além dos modelos biomédicos de pesquisa - aí também há artigos que se voltam para a alimentação e para o corpo. O mesmovale para livros e capítulos de livros que tratam da comida como alimentos simbolizado e do corpo socialmente construído. Não há, contudo, bases de dados que permitam chegar, hoje, a esses trabalhos em sua totalidade. Há, isto sim, alguns estudos que buscaram analisar esse conjunto e, tal como Ana Maria Canesqui (1988, p. 215), indicam que:

As contribuições antropológicas analisadas deixaram um alerta aos estudiosos do campo da nutrição quanto aos limites e inadequações das abordagens que circunscrevem a cultura aos tabus e crenças alimentares, conforme criticamos no decorrer do texto. Resta ainda um elenco de estudos nesta área que não pode prescindir do conhecimento antropológico, sempre que se tenha em jogo ultrapassar a dimensão estritamente biológica da questão nutricional e alimentar. 
Klotz-Silva e colaboradores (2010, p. 413), revisitando esses estudos, consideram que esse lugar marcado pela visão biomédica ainda "se ressente e demanda um domínio mais sólido de conceitos e métodos capazes de enfrentar a complexidade da realidade e dos problemas além das bancadas dos laboratórios, na vida em sociedade". Reiterando essas percepções, Francisco Vasconcelos analisa teses e dissertações defendidas nos programas de pós-graduação stricto sensu inseridos na área de avaliação "Nutrição" na Coordenação Aperfeiçoamento de Pessoal de Nível Superior (Capes) no Brasil e identifica a:

[...] hegemonia [...] das tendências filosóficas ligadas ao Positivismo e às Ciências Biológicas, atraindo o interesse de $92,5 \%$ dos pesquisadores. As abordagens qualitativas e mistas contribuíram com apenas 7,3\% dos estudos, expressando a influência das Ciências Sociais e Humanas e das correntes filosóficas (dialética e fenomenologia) sobre um grupo restrito de pesquisadores [...]. A distribuição das dissertações e teses [...] reafirma a complexidade, amplitude e heterogeneidade metodológica e epistemológica da conformação do campo de produção de conhecimento em Alimentação e Nutrição, exigindo a construção coletiva de projetos políticos que busquem a interdisciplinaridade dos diferentes núcleos [de saberes] que estruturam o campo. (VASCONCELOS, 2015a, p. 5)

Em outras palavras, há um conjunto minoritário de estudos que tematizam corpo e alimentação oriundos do campo da alimentação e nutrição. Entre esses, identificam-se aqueles sólidos e conceitualmente bem conduzidos em meio a outras abordagens que ainda carecem de ancoragem em autores, teorias e perspectivas analíticas próprias das Humanidades.

Feita a ressalva, retomemos a Revista de Nutrição. Procedendo como quem parte para uma mirada ampla, uma rápida aproximação ao conjunto de artigos publicados nesse periódico desde 1997 foi realizada. Efetuamos diversas buscas a partir de palavras, como: "urbano", "urbana”, urbanidade", "urbanização", "rural”, "ruralidade”. Recuperamos 42 artigos no período em que o periódico se encontra indexado nessa base. Os sentidos implicados nesse conjunto de expressões trazem a marca da palavra dicionarizada: delimitação geográfica, física. O dizer cotidiano 
que identifica o senso comum está presente nas ideias de "área rural” e "área urbana", "zona rural" e "zona urbana"; em trechos que mencionam "domicílios distribuídos em localidades urbanas e rurais de determinados municípios" ou "a área mais pobre do município no perímetro urbano e na zona rural" ou "agricultura familiar rural" ou ainda como aspectos de ordenamento metodológico para trabalhos de campo, como no estabelecimento de "[ $\mathrm{xx}$ domicílios] no extrato urbano e $[\mathrm{xx}]$ no extrato rural". A visão estanque de um mapa físico no qual se recorta localidades distintas, separadas por linhas que delimitam conjuntos de indivíduos objetivamente fixados, predomina nos desenhos metodológicos e nas discussões decorrentes dessas concepções. Em raros casos, uma noção de movimento é mencionada como "transição de um cenário rural para o urbano", o que mais se assemelha ao deslocamento de indivíduos desprovido, contudo, de problematização ou análise da ordem simbólica, das experiências humanas, dos afetos, dos valores éticos e morais, das relações de poder que atravessam os fenômenos em exame.

Região como recorte geográfico institucionalizado foi o que encontramos em 90 artigos que mencionavam a "Região Nordeste do Brasil", a "Região Metropolitana do Rio de Janeiro, a "Região Oeste da cidade de São Paulo" ou uma determinada "Região do Estado de Santa Catarina", entre outras variações cruas das divisões políticas formais do país.

Similarmente, encontra-se o local presente em 44 artigos quando são mencionados o "planejamento intersetorial em nível local”, a "biodiversidade local", "o refeitório [como] local de consumo", a "equipe local”, o "local institucionalmente reconhecido da pesquisa científica", o "local de trabalho", a "realidade local" ou o "local de aquisição de frutas". Como uma versão em tamanho menor da área urbana ou da região, a ideia de local segue na mesma esteira da concretude dos mapas, das linhas formais de demarcação. Cartografia não encontra expressão nesses trabalhos, sequer como materialização gráfica da superfície terrestre, o que, em ideia, equivaleria ao local representado ou a um mapeamento, esta sim palavra encontrada em nossos exercícios exploratórios guardando os significados já registrados. 
"Ambiente" corresponde a outro vocábulo que se manifesta em 49 trabalhos publicados na Revista de Nutrição falando também da situação geográfica de cunho espacial onde se dá, por exemplo, a compra de alimentos. Pode ser uma escola e seu entorno, uma universidade, uma empresa onde se trabalha, um bairro, uma parcela de algum município ou ele todo. De qualquer modo, alinha-se a ideia de ambiente às concepções relativas a urbano, rural, regional, local que seguem, assim, compondo a produção científica no campo da alimentação e nutrição, seja como elemento operacional de pesquisa, seja como componente de gestão de programas ou ações em saúde, educação ou assistência social, por exemplo.

Encontramos o território e a territorialidade mencionados em não mais que cinco artigos. Alguns referem-se meramente ao "território nacional". Buscando certa diferenciação e como quem quer escapar a esse padrão anteriormente sugerido, as palavras deixam entrever a tentativa de enunciação de um novo discurso dirigido à gestão de planos governamentais. Trata-se da formulação de atividades ditas participativas que venham a articular equipes técnicas e populações de "territórios" nitidamente delimitados em face das diretrizes formuladas no âmbito do Sistema Único de Saúde (SUS) brasileiro, quais sejam: integralidade, “territorialidade”, educação popular e participação social, interdisciplinaridade, intersetorialidade, educação permanente em saúde. Em sua maioria são, contudo, frágeis na apresentação dos fundamentos teóricos que possam estar sustentado a proposição. Milton Santos, para citar um estudioso do tema, é autor que aparece pontualmente nessas abordagens; doravante e quiçá, em eventual apropriação pelo campo da alimentação e nutrição. Nenhum outro se fixa com destaque ou recorrência nesse espaço de publicações.

Interessante e mesmo curioso é notar o que marca o lugar. Este que, de imediato, nos conduz a um local, em nossos levantamentos, aparece em quatro artigos. Algumas vezes como expressão de um posicionamento social, de um modo de se colocar diante de certos fenômenos em sociedade, quando se volta para os "discursos acerca do lugar do nutricionista [nos serviços de saúde]" ou para a ocupação "de lugares chave 
na necessária reinvenção de si mesmos de suas relações com a comida" ou da cura que exige do sujeito a assunção de "um lugar ativo" na vida. Largas e fortes em seus fundamentos analíticos, essas discussões estabelecem intensa articulação entre distintos campos da ciência, percorrendo autores e teorias com a propriedade necessária, ainda que não tenham vínculo algum com delimitações de ordem geográfico-espacial. Para não deixar de mencionar a polissemia que nos envolve, a palavra "lugar" aparece ainda para designar trocas de posições em meio a fenômeno socioculturais quando, ao tratar da perspectiva da modernidade alimentar, encontramos que "o lanche está tomando o lugar do jantar".

Por fim, quanto à "cidade", essa palavra aparece em 74 artigos servindo para anteceder um nome como "cidade do Rio de Janeiro", "de São Paulo", "de Belo Horizonte" e assim por diante, informando sobre algum elemento que possibilite a identificação de onde foi feita uma coleta de dados ou uma intervenção ou algo desse naipe.

Termos como "espaço urbano", "ambiente alimentar", "territórios" e "regiões" marcam presença nesses esforços em acepção de caráter dicionarizado aludindo a algo próximo de "Grande aglomeração de pessoas em uma área geográfica circunscrita, com inúmeras edificações, que desenvolve atividades sociais, econômicas, industriais, comerciais, culturais, administrativas etc" (CIDADE, 2018) ou, em perspectiva mais afeita à biomedicina, correspondendo a dimensões, predominantemente tratadas como um espaço geográfico físico delimitado no qual eventos dissecados em variáveis correspondentes são considerados em relações de associação ou de determinação para específicos desfechos previamente delineados.

Reafirma-se, assim, a predominância das perspectivas anteriormente mencionadas relativamente ao tom positivista dos estudos aqui em exame, bem como a necessidade de investimentos em esforços que possam contribuir para o alargamento dos olhares quando procuram situar os fenômenos estudados no contexto sociocultural e que, para tanto, recorrem a ideias do venha a ser o urbano, o rural, a região... Ou as cidades. No âmbito das Ciências Humanas e Sociais, essas categorias encontram-se bastante presentes, ancoradas em uma vasta pluralidade 
de visões de mundo, fundamentos teóricos e epistemologias, abrindo, assim, caminhos para possibilidades interpretativas ricas e diversas acerca do corpo e da alimentação. Destacam-se as perspectivas analíticas que partem da categoria "cidade", para além da sua expressão física, como expressão e movimento da vida em sua complexidade e magnitude e cuja análise demanda diálogos entre distintos campos da ciência.

De origem latina, como civitate, a palavra guarda noção que se aproxima de civitas, dando chão para a perspectiva da civilização. Como processo civilizatório, discutido por Norbert Elias (1993), a cidade poderia, como expressão de ponta dos ordenamentos sociais mais recentes, nos remeter à imagem ocidental de apreço pela superioridade que lhe confere o conhecimento tecnológico que construiu e do qual dispõe, bem como pelo quanto pesa o controle cada vez maior das emoções. Estar na cidade, viver nela, desejá-la pode significar a distinção conferida pelos edifícios espelhados e metálicos, transportes de alta performance, desenvolvimento de equipamentos científicos de ponta, modas e valores de última geração. Tudo isso a exigir, ao mesmo tempo, novos comportamentos a serem aprendidos no caminho da busca pela distinção na vida marcada por desigualdades mais e mais intensas, da busca permanente pelo prazer e pela felicidade cada vez mais individualizada no mundo do consumo que se expressa, principalmente, nas cidades onde segue a passos largos transformação das pessoas em mercadorias, como nos diz Zygmunt Bauman (2008).

Duch (2015) destaca o quanto os estudos sobre a cidade têm se multiplicado nas primeiras décadas do século XXI, frente às intensas mudanças experimentadas no âmbito urbano e no conjunto da vida pública, parecendo-lhe sensato pensar que a questão urbana ocupa hoje o lugar que a questão social ocupara nos primórdios do século XX. Em um movimento de repensar as cidades, o autor ainda leva em consideração a virada espacial (spatial turn) que vem tomando lugar nas últimas cinco décadas, desencadeando uma reflexão crítica sobre o espaço e renovando, por seu turno, os estudos geográficos. Nesta esteira, destaca-se, por exemplo, o novo conceito de espacialidade da geógrafa Doreen Massey (2008), como 
possibilidade de repensar a globalização, as cidades e o lugar. Vale ainda ressaltar que tais perspectivas foram mobilizadas e ainda mobilizam novas epistemologias, teorias e métodos para abordar o tema, pautadas na transversalidade de disciplinas que historicamente se voltaram ao tema.

Em meio a tal complexidade, as cidades guardam muito de materialidades e subjetividades: em nada lineares e tensionadas com referências causais cartesianas, trazem marcas que fazem delas ambíguas, paradoxais, contraditórias. Pequenas e pacatas, arrojadas e dinâmicas, imensas a configurar conglomerados que parecem não ter fim, agressivas e violentas, ancoradas nas mais profundas desigualdades, (des)encontrando-se em comunicações virtuais, anunciam, enfim, as pós-metrópoles: CyberCities (VASCONCELOS, 2015b) e narrativas que tratam da desmaterialização do espaço físico e lidam com um tempo não cronológico. Estruturando novas concretudes e subjetividades e sendo por elas estruturada, segue essa pós-cidade ou hipercidade ou cidade líquida transformando imaginários e construindo um mundo a ser conhecido.

Assim, nesta obra, as cidades não são consideradas apenas como um cenário no qual as relações dos sujeitos vivem e dão sequência ao seu cotidiano. Além de berço de experiências para aqueles que a habitam e que por ela transitam, a própria cidade se faz em processos que produzem uma pluralidade de vivências, narrativas, subjetividades, afetividades, memórias e lembranças. Cidades e sujeitos se entrelaçam e, simultaneamente, produzem-se a si mesmos conformando movimentos de pensar, agir e sentir em constante transformação. E é nessa tessitura que seus espaços de poder, do público e do privado, as exclusões e inclusões sociais, dentre inúmeras outras questões, se constituem.

Ainda são poucos pesquisadores do campo da alimentação e nutrição que se propõem a abordar essas temáticas nesta perspectiva, concebendo a cidade como experiências de comensalidades múltiplas, de corpos distintos ou ainda tomando essas práticas alimentares e corporais como produtoras das cidades e essas, de nós mesmos. A consciência em relação a essa lacuna e o reconhecimento de seu potencial analítico levaram à chamada para a produção desta coletânea a partir de um "tom" provocativo, 
instigando estudiosos do campo a apresentarem a cidade como mais uma das perspectivas analíticas que permeiam os seus estudos.

O antropólogo francês Claude Lévi-Strauss, em sua obra Mitológicas, tomou a cozinha e a preparação dos alimentos para pesquisas sobre diversos mitos indígenas. Mais do que isso, argumentou que a comida pode ser considerada na compreensão do que nos faz humanos. Se os mitos são bons para pensar, se a comida é boa para pensar, as cidades também podem ser estratégicas para pensar, tanto em sua concretude quanto nos signos que carrega e transporta nos corpos e nos alimentos enquanto mediadores de relações sociais. A cidade como uma linguagem, como um conjunto complexo de códigos que nos permite compreender as (trans)formações da sociedade à qual pertencemos, que nos constrói e que nos confere sentido, do mesmo modo que nós atribuímos sentido a cidade, como um ato social que incorpora múltiplas dimensões do ser humano.

\section{REFERÊNCIAS}

BAUMAN, Z. Vidas para consumo: a transformação das pessoas em mercadorias. Rio de Janeiro: Jorge Zahar, 2008.

CANESQUI, A. M. Antropologia e alimentação. Revista de Saúde Pública, São Paulo, v. 22, n. 3, p. 207-216, 1988.

CIDADE. In: MICHAELIS: dicionário brasileiro da língua portuguesa. São Paulo: Melhoramentos, [2018]. Disponível em: https://michaelis.uol. com.br/moderno-portugues/busca/portugues-brasileiro/cidade/. Acesso em: 1 set. 2018 .

DUCH, L. Antropología de la ciudad. Barcelona: Herder Editorial, 2015.

ELIAS, N. O processo civilizador: uma história dos costumes. Rio de Janeiro: Zahar, 1993.

KLOTZ-SILVA, J. et al. Alimentação e cultura como campo científico no Brasil. Physis: Revista de Saúde Coletiva, Rio de Janeiro, v. 20, n. 2, p. 413-442, 2010. 
LÉVI-STRAUSS, C. O cru e o cozido. São Paulo: Cosac Naify, 2004.

(Mitológicas, v. 1).

MASSEY, D. B.: Pelo espaço: uma nova política da espacialidade. Tradução de Hilda Pareto Maciel e Rogério Haesbaert. Rio de Janeiro: Bertrand Brasil, 2008.

VASCONCELOS, F. A. G. The construction of scientific knowledge in Food and Nutrition: Analysis of dissertations and theses in the Brazilian postgraduation programs in Nutrition. Revista de Nutrição, Campinas, v. 28, n. 1, p. 5-16, jan./fev. 2015a.

VASCONCELOS, P. A. As metamorfoses do conceito de cidade. Mercator, Fortaleza, v. 14, n. 4, p. 17-23, dez. 2015b. Número especial. 


\section{Para que serve a cidade?}

LUIS ANTONIO DOS SANTOS BAPTISTA

A rua é um fator da vida das cidades, a rua tem alma! Em Benarès ou em Amsterdão, em Londres ou em Buenos Aires, sob os céus mais diversos, nos mais variados climas, a rua é a agasalhadora da miséria. Os desgraçados não se sentem de todo sem o auxílio dos deuses enquanto diante dos seus olhos uma rua abre para outra rua. A rua é o aplauso dos medíocres, dos infelizes, dos miseráveis da arte.

( $A$ alma encantadora das ruas, João do Rio).

Os alicerces seguros do pensamento inspiram-se na precisão do projeto urbanístico elaborado por um único arquiteto, afirma René Descartes no Discurso do método. A cidade, projetada à luz da razão, impediria a errância da alma. "No quarto fechado, o eu cartesiano se recolhia na 
interioridade da dúvida radical e da auto-reflexão para escapar ao engano". (GAGNEBIN, 1996, p. 242) Para Descartes (1979 apud GAGNEBIN, 1996), nas cidades cuja história exibe a diversidade das edificações nos estilos e nas diferentes concepções de mundo que as projetou, nas curvas e dimensões desiguais das ruas, o espírito se perderia, só encontraria o intolerável erro. A razão seria aviltada. A topologia urbana na retidão do seu traçado funcionaria como a metáfora correta para o pensamento.

Permanecia o dia inteiro fechado num quarto bem aquecido onde dispunha de todo o vagar para me entreter com os meus pensamentos. Entre eles, um dos primeiros foi que me lembrei de considerar que, amiúde, não há tanta perfeição nas obras compostas de várias peças, e feitas pela mão de diversos mestres, como naquelas em que um só trabalhou. Assim, vê-se que os edifícios empreendidos e concluídos por um só arquiteto costumam ser mais belos e melhor ordenados do que que muitos procuraram reformar, fazendo uso de velhas paredes para outros fins. Assim, essas antigas cidades que, tendo sido no começo pequenos burgos, tornaram-se no correr do tempo grandes centros, são ordinariamente tão mal compassadas, em comparação com essas praças regulares, traçadas por um engenheiro à sua fantasia numa planície, que, embora considerando os seus edifícios cada qual à parte, se encontre neles muitas vezes tanta ou mais arte que nos das outras, todavia, a ver se acham arranjados, aqui um grande, ali um pequeno, e como tornam as curvas e desiguais, dir-se-ia que foi mais o acaso do que a vontade de alguns homens usando de razão que assim os dispôs. (DESCARTES, 1979 apud GAGNEBIN, 1996, p. 246)

No mapa da urbe cartesiana, o acaso, o contingente seria corrigido pelo projeto de um só arquiteto na execução de um modelo atemporal. Misturas de tempos, curvas imprecisas turvariam horizontes necessários para o encontro da verdade do Eu tutelado pelos alicerces da razão. Impossível perder-se, errar um caminho, uma meta, no traçado das ruas onde sinuosidades faltariam. Da harmonia e da regularidade, a urbe tornar-se-ia bela e funcional. O pensamento localizaria o conforto necessário para o encontro das suas verdades; nada o perturbaria. Imperfeições oriundas das misturas de várias mãos, de diferentes peças e estilos das edificações inexistiriam. Na geometria das ruas, o equilíbrio do espírito 
seria efetivado. A cidade harmônica, protegida do inesperado e do caos, teria como meta educar o espírito.

Em Barcelona, assim como em outros lugares no século atual, a cidade também exerce a função de educar. Parques, rios, favelas, shopping, praias, escolas e universidades, ruas, entre outros espaços, são convocados à promoção do desenvolvimento pessoal, social e político do citadino do futuro. O potencial humano de crianças e jovens na Carta das cidades educadoras ${ }^{2}$ teria na urbe a chance de desenvolver as qualidades necessárias para o equilíbrio social. Na carta, elaborada em Barcelona, a cidade transforma-se na escola ampliada:

A cidade será educadora quando reconheça, exerça e desenvolva, para além das suas funções tradicionais (econômica, social, política e de prestação de serviços), uma função educadora, isto é, quando assuma uma intencionalidade e responsabilidade cujo objetivo seja a formação, promoção e desenvolvimento de todos os seus habitantes, a começar pelas crianças e pelos jovens. (CARTA DE BARCELONA, 1990 apud VIEIRA, 2012, p. 57)

A escola sem muros apropria-se da paisagem urbana, das instituições, do mobiliário urbano no intuito de formar futuros cidadãos. Deverá estar atenta ao local apropriado para que a potencialidade dos jovens se desenvolva:

O governo municipal deve dotar a cidade de espaços, equipamentos e serviços públicos adequados ao desenvolvimento pessoal, social, moral e cultural de todos os seus habitantes, prestando uma atenção especial à infância e à juventude. (CARTA DE GENOVA, 2004 apud VIEIRA, 2012, p. 60)

2 Segundo Elisa Viera (2012, p. 58), "em 1971 a UNESCO constitui uma Comissão Internacional para o Desenvolvimento da Educação a fim de estabelecer reflexões e proposições de alcance mundial sobre o tema. Dali surgiu a idéia de uma cidade educativa. [...] A cidade educativa foi um antecedente importante para aquilo que, em 1990, passaria a chamar-se cidade educadora. A primeira versão da Carta das Cidades Educadoras foi escrita em Barcelona, em 1990, pelos representantes das cidades participantes do I Congresso Internacional das Cidades Educadoras. [...] Criou-se em 1994, a Associação Internacional das Cidades Educadoras. Dela fazem parte 434 cidades distribuídas em 35 países, estando na Europa a maior concentração. O Brasil faz-se presente com 14 municípios". 
À semelhança de um grande jardim, a urbe acolhe potencialidades como sementes para que, no futuro, germinem, desenvolvam vigorosas rumo a uma prometida cidadania. Crianças e jovens crescerão como árvores nesta cidade jardim. Das sementes, o futuro já estaria definitivamente decidido. Do urbano, esperam-se apenas cooperação e não interferência. Cenário, solo adubado, a paisagem que acolhe sem interferir são qualidades da cidade que servirão para educar e formar citadinos na escola sem muros. O que a literatura tem a dizer sobre harmonia, equilíbrio e fecundidade de uma cidade? Para que serve esse assentamento humano?

Cidades revestem-se de inocência, de neutralidade quando propiciam aos homens a promoção de felicidade e de segurança. Inocentes, se restringiriam a apenas ser o assentamento eficaz para suprir necessidades, facilitar a circulação de riquezas, educar e civilizar. Neutras, apartam-se das tramas do poder que as desenham. Na epígrafe desta escrita, o cronista João do Rio subverte estas atribuições: a rua tem alma. O jornalista carioca, longe de definir a alma da rua como a essência da tradição de um lugar, à semelhança da identidade de um logradouro, sugere que a alma da rua diferencia-se das marcas identitárias ou da representação do universo humano. Para o cronista carioca, ela não seria a energia vital da cidade definida como organismo integrado, a parte invisível do corpo da urbe. A alma da rua é inumana, singular. ${ }^{3}$ Dela, qualidades humanas inexistiriam: "A rua continua matando substantivos, transformando a significação dos termos, impondo aos dicionários as palavras que inventa, criando o calão que é o patrimônio clássico dos léxicos futuros”. (RIO, 1991, p. 4) Ela mata na corrosão inventiva de outras formas de sentir e de viver; destruição perigosa para certa concepção de cidade, a que educa e civiliza. A alma da rua aniquila também adjetivos, tempos e espaços ancorados na harmonia dos universais. Destrói e cria ao afirmar

3 Sobre a corrosão da alma das ruas na obra de João do Rio, Virginia Célia Camilotti (2008, p. 126) argumenta que "adulteradora do léxico clássico e inventora dos léxicos futuros, a rua incide, da mesma forma, sobre tudo aquilo que a percorre, que nela se move ou a habita: valores morais, relações sociais e formas do sentir e do viver. É porque está especialmente interessado nestas corrosões das formas consagradas do sentir e do viver que João do Rio indica a rua como seu motivo principal". 
o campo inesgotável de possibilidades. Em algumas metrópoles, ela se apresenta como mera passagem onde nada ameaçaria a estabilidade das consagradas formas de sentir, de habitar e viver. Aparentemente morta, a rua se exibe, porém, nos cantos, esquinas, no espaço vazio da sua paisagem algo acontece, ou poderá acontecer a qualquer momento.

Apesar de ser projetada por modelos urbanísticos para suprir necessidades dos citadinos, a alma da rua é um artefato não restrito aos limites da sua visibilidade. O uso e o desuso dos fazeres cotidianos, as histórias justapostas em suas camadas de cimento, sonhos heterogêneos e tempos díspares que a habitam a tornam irreconhecível para uma localização delimitada pela visibilidade geográfica, militar, psicológica ou antropológica. Até mesmo vazia, desocupada, a rua exibe a sua alma inumana, laica, material, composta por um coletivo de restos de coisas usadas marcadas por acontecimentos do presente, do ontem, por prenúncios de futuro; coletivo maculado por díspares afetos humanos, ou não. Walter Benjamin (1989, p. 194) o define como inquieto e agitado:

As ruas são a morada do coletivo. O coletivo é um ser eternamente inquieto, eternamente agitado, que, entre os muros dos prédios, vive, experimenta, reconhece e inventa tanto quanto os indivíduos ao abrigo de suas quatro paredes. Para esse ser coletivo, as tabuletas das firmas, brilhantes e esmaltadas, constituem decoração mural tão boa ou melhor que o quadro a óleo no salão do burguês.

Coletivo inquieto, sem forma estável, porém intenso, com modulações variadas. Intensidade não ignorada pelos que lutam entre suas bordas; também não ignorada por agentes da ordem que tentam sufocar essas lutas. Intensidade não despercebida até mesmo para os que circulam, passam indiferentes como se a cidade não existisse; para os que matam quando a alteridade é um estorvo, para os que desprezam qualquer coisa que não seja o eu. Intensidade insufladora de atenção para os caçadores do acaso, para despejados, refugiados, humilhados pelos agentes da ordem, sem atenção, fenecem. Coletivo composto por modulações de intensidades não ignorado pelos que se contagiam ou rejeitam 
os seus paradoxos. Força sem adjetivos e substantivos, incitadora de políticas destituídas de protagonistas definidos; força que lega à cidade o sentido de uma incansável arena de embates. Civilizar, educar, aprimorar e conquistar direitos seriam perpassados pela intensidade do inquieto coletivo mantendo-os em constante instabilidade. Metas cívicas, projetos de cidadania seriam inquiridos drasticamente pelos paradoxos que irrompem da urbe viva, desigual e tensa. A alma da rua possui rosto, mas qual? Para que serve a cidade?

João do Rio, ao afirmar a existência da alma estranha aos urbanistas, aproxima-se de Walter Benjamin, avizinha-se do rosto do mundo das coisas, presença intensiva marcante nos jogos infantis descrito pelo filósofo berlinense. Nos jogos dos infantes, crianças:

sentem-se irresistivelmente atraídas pelo resíduo que surge na construção, no trabalho de jardinagem ou doméstico, na costura ou na marcenaria. Em produtos residuais reconhecem o rosto que o mundo das coisas volta exatamente para elas, e para elas unicamente. (BENJAMIN, 1987, p. 19)

No jogo infantil, o rosto do mundo das coisas alheio às classificações inequívocas dos objetos, às funções do dia a dia, revida, acena para o olhar e insufla a ação. As coisas têm almas singulares que incitam experimentações intermináveis. A rua cujo rosto pertence ao mundo das coisas, apela por jogos, ou lutas, inesgotáveis:

Crianças e artistas se põem a experimentar com o mundo, isto é, a destruí-lo e a reconstruí-lo, porque não o consideram como definitivamente dado. Essas brincadeiras essenciais implicam uma noção de ação política que não visa a transformação do mundo segundo normas prefixadas, mas a partir de exercícios e tentativas nos quais a experiência humana - tanto espiritual e inteligível como sensível e corporal - assume outras formas. (GAGNEBIN, 2014, p. 175)

$\mathrm{Na}$ experimentação com o mundo citada por Gagnebin inspirada nas análises de Benjamin sobre a política dos jogos, os materiais desafiam o jogador; resíduos, restos, sobras, coisas insignificantes afirmam suas diferenças colocando em cheque a soberania do Sujeito, ou as suas 
naturalizadas qualidades. $\mathrm{O}$ mundo das coisas, da radicalidade da empiria, nega ao jogador o conforto do reconhecimento de uma ideia, ou de um enunciado inteligível. A face da cidade poderá, neste jogo político, profanar a paisagem que a limita, desdobrar formas, alertar para perigos de outros lugares, tornar-se um pequeno mundo feito de entrelaçamentos inesgotáveis. Walter Benjamin (1996, p. 26-27) apresenta esta face urbana na literatura dos surrealistas:

No centro desse mundo das coisas está o mais onírico dos seus objetos, a própria cidade de Paris. Mas somente a revolta desvenda inteiramente o rosto surrealista (ruas desertas, em que a decisão é ditada por apitos e tiros). E nenhum rosto é tão surrealista quanto o rosto verdadeiro de uma cidade. [...] Também a Paris dos surrealistas é um 'pequeno mundo'. Ou seja, no grande, no cosmos, as coisas têm o mesmo aspecto. Também ali existem encruzilhadas, nas quais sinais fantasmagóricos cintilam através do tráfico; também ali se inscrevem na ordem do dia inconcebíveis a nalogias e acontecimentos entrecruzados.

Espelho dos mistérios da alma, revelação das agruras e virtudes do humano para o autoconhecimento, arte necessária para a compreensão das relações sociais e do mundo são funções da literatura comumente utilizadas nas Ciências Humanas. Salvação, desvendamento da realidade, crescimento espiritual a qualificam aproximando-a do reino do sagrado. Na obra de Walter Benjamin, esta missão é preterida. Certa literatura esquivar-se-ia de salvar, representar ou ilustrar fatos ou realidades. Da poesia de Charles Baudelaire, dos romances do movimento surrealista, da obra de Kafka, de Marcel Proust, ela interfere drasticamente em suas análises sobre as relações entre cultura e capitalismo; na elaboração das teses sobre a história, assim como na presença do fascismo nos pequenos atos, objetos e cenas do cotidiano. Para Benjamin (1996, p. 225), "nunca houve um monumento de cultura que não fosse também um monumento de barbárie". Assertiva fulminante para os que delegam à arte, à cultura, o reino da salvação ou da inocência.

A literatura não seria mais um instrumento de acréscimo, uma interferência que manteria ileso seu equipamento teórico, mas de 
interpelação aos conceitos e teorias utilizados em seus estudos referentes à modernidade e ao nascimento do nacional socialismo alemão. Para o filósofo berlinense esta modalidade de arte assemelhar-se-ia ao uso das citações em sua obra: "citações em meu trabalho são salteadores no caminho, que irrompem armados e roubam ao passante a convicção". (BENJAMIN, 1987, p. 61) As obras literárias utilizadas por Benjamin o aturdiram, roubaram convicções sedimentadas, impelindo-o a estranhar o que antes lhe servia de horizonte. Da poesia, assim como da prosa poética de Charles Baudelaire, as relações entre cultura e capitalismo têm na cidade de Paris o assalto às suas convicções. A urbe dos surrealistas irrompe como salteadores no seu caminho furtando-o das certezas das reflexões tradicionais sobre a metrópole do capitalismo. A cidade, via literatura, insuflou a criação do peculiar marxismo do filósofo alemão. Benjamin aponta para sonhos, fantasmagorias do modo de produção capitalista, para a barbárie do fascismo a perpassar projetos arquitetônicos, brinquedos, ruas, limiares e fronteiras urbanas, denotando a cultura o lugar de assujeitamento e de enfrentamento de intermináveis lutas políticas. Para que serve a cidade quando certa literatura transtorna seus limites?

Lâmina cortante produtora de cesuras, artefato para dissecar, arma de combate, instrumento eficiente para criar fissuras, são qualidades e funções possíveis de uma cidade. O poeta Sebastião Uchoa Leite, no poema "Tempus Fugit N.1", denota a urbe com esses atributos; no poema, ela se diferencia do palco neutro das relações sociais, ou o cenário para luzes e sombras de um soberano Humano. A cidade dilacera a compacidade do Sujeito, perturba a nitidez de uma paisagem. Corte, despedaçamento, aberturas de sulcos em superfícies humanas, ou inumanas, expressariam funções perigosas para ideias desejosas de permanecerem estáveis e ilesas. Risco mortal para o pensamento necessitado de proteção e conforto; o pensar refratário a contágios e desestabilizações. A urbe desenhada pela imagem do utensílio dilacerador interrompe a eficiência de lógicas universais a tutelar o citadino; inquire racionalidades por meio de cesuras na continuidade de uma análise. 
Provoca mudanças de caminhos, multiplica atalhos, encruzilhadas, desvios no trajeto ideal para o alcance de uma verdade. A urbe esquiva-se de ser o bálsamo das agruras de uma utopia fracassada; nela inexistiria consolo ou solução definitiva para um fracasso, ou o júbilo pela vitória da realização de uma utopia. Tensões insolúveis a ocupam na criação de inesgotáveis paradoxos. Nada perdura conclusivamente. A cidade como lâmina fria decepa a solidez de valores ou a clareza de horizontes. Cortante, fragmenta totalidades inquestionáveis: uma rua, um muro, o lixo sobre a calçada, um rosto, o gesto silencioso, a alegria de um corpo, o cadáver inerte, uma parede, um grito poderão implodir a conclusão de uma análise ou de uma sentença. À semelhança de uma lâmina, a cidade é habitada por histórias fragmentadas produzida por forças que desafia a racionalidade dos cálculos. Forças, segundo Michel de Certeau (1998, p. 189-191), que irrompem das inesperadas invenções do cotidiano:

Os lugares são histórias fragmentárias e isoladas em si, dos roubados à legibilidade por outro, tempos empilhados que podem se desdobrar, mas que estão ali antes como histórias à espera e permanecem no estado de quebra-cabeças, enigmas, enfim simbolizações enquistadas na dor ou no prazer do corpo. [...] A infância que determina as práticas do espaço desenvolve a seguir os seus efeitos, prolifera, inunda os espaços privados e públicos, desfaz as suas superfícies legíveis e cria na cidade planejada uma cidade 'metafórica' ou em deslocamento, tal como a sonhava Kandinsky: 'uma enorme cidade construída segundo todas as regras da arquitetura e de repente sacudida por uma força que desafia os cálculos'.

A cidade feliz, ou infeliz, não teria sentido de existir quando encarna a função de uma navalha afiada, ou do quebra-cabeça indicado por Certeau, a espera do desdobramento de narrativas. Paisagens, ícones de um lugar, perdem a clareza de suas bordas, a nitidez para o reconhecimento identitário. A urbe cortante está sempre insuflando prováveis montagens de histórias e de formas de luta; montagem feita dos restos de sonhos deixados pela metade do caminho, de cenas banais, ou não, do cotidiano. Realização temporária, porque dos paradoxos produzidos pelas cesuras da urbe a eternidade dos símbolos, dos horizontes 
fracassam; segundo Kandinsky, sacudidos "por uma força que desafia os cálculos”. Para que serviria uma cidade?

O poeta Sebastião Uchoa Leite (1988, p. 2) define a cidade como "lâmina fria cortando cômodas suposições. Uma lâmina curva que decepa a sóbria reta que se traçou na ponte". ${ }^{4}$ Para o poeta pernambucano, o olhar protegido apartado do mundo neutralizaria o cortante poder da urbe: "Aqui deste alto pavimento, isolado do real vivido e dividido pelas folhas de vidro e aço, vê-se a ponte em perspectiva". (LEITE, 1988, p. 2) Do alto, a previsibilidade do percebido permaneceria intacta, a nitidez da paisagem confortaria o Sujeito que a contempla. Porém, lá fora, no solo, "a sóbria reta que se traçou na ponte", a totalidade da paisagem, da harmonia do real é decepada pela cidade. Na rua, à luz de Walter Benjamin (2004, p. 14), uma batalha é anunciada:

A força com que uma estrada no campo se nos impõe é muito, consoante ela seja percorrida a pé ou sobrevoada de. [...] Só quem percorre a estrada a pé sente o seu poder e o modo como ela, a cada curva, faz saltar do terreno plano (que para o aviador é apenas a extensão da planície) objetos distantes, clareiras, perspectivas, como a voz do comandante que faz avançar soldados na frente de batalha.

A urbe oferece uma tensão insolúvel, ensejada pela "máquina humana viva, a mecânica da vida concreta”, da qual sóbrias ideias, projetos são produzidos, testados e destruídos infinitamente. À semelhança de uma navalha, de uma faca afiada, a cidade cria e dilacera sem tréguas, como uma máquina, como um artefato. Fora da fronteira delimitada por "folhas de vidro e aço", nada se mantém intacto. A cidade, proposta por Uchoa, tem no cotidiano o fio cortante da maquinaria inacabada e imprevisível da vida concreta; o concreto onde efetiva-se a radicalidade

4 Segue o poema "Tempus Fugit N.1": "Aqui deste alto pavimento, isolado do real vivido e dividido pelas folhas de vidro e aço, vê-se a ponte em perspectiva. Não se vê o dragão nem a donzela daquele cenário de Ucello nem a Ville Blanche de Vieira da Silva, reflexos compostos em abstração, mas a máquina humana viva, a mecânica da vida concreta. O outro lado não é previsível: a cidade é uma lâmina fria cortando cômodas suposições. Uma lâmina curva que decepa a sóbria reta que se traçou na ponte. Matemática do passeio, composição do livre arbítrio, adeus! As traças devoram os livros de estampas góticas ou modernas". (LEITE, 1988, p. 2) 
desacomodadora da empiria. Desprotegido das paredes de vidro e aço, o olho que tudo alcança, o Sujeito artífice das sóbrias perspectivas, a paisagem irretocável correm o risco de ferir-se mortalmente no chão da urbe. Para que serve a cidade?

Manuel Bandeira, na contramão das "sóbrias perspectivas" do olhar confinado às fronteiras de vidro e aço, reacende a "máquina humana viva, a mecânica da vida concreta" no poema "O beco": "Que importa a paisagem, a Glória, a baía, a linha do horizonte? - O que vejo é o beco". O poeta, desviando-se da cidade espetáculo, da paisagem que não revida o olhar, elege o lugar cortante do Beco da Lapa, no Rio de Janeiro, onde se entrelaçam histórias de vidas infames. Local de lutas e fracassos de trabalhadores, de misturas desarmônicas, espaço sujo de mundo opondo-se à imaculada paisagem da cidade cenário. Imagens emblemáticas do Rio de Janeiro cartão postal não lhe contagiam, não o deslocam de lugar; são imagens demarcadas por horizontes precisos confortáveis para quem as vislumbra. Do Beco sem saída, a estreita passagem prenuncia histórias imprevisíveis, vozes dissonantes passíveis de cortar como uma navalha a conclusão de uma análise. Algo poderá acontecer no Beco. Não só a natureza imóvel como cenário é desinteressada pelo poeta, mas a pobreza como paisagem. Próxima ao interesse do poeta afirma Vera da Silva Telles (apud WALTY, 2007, p. 62):

Nessas formas de encenação pública, a pobreza é transformada em paisagem que lembra a todos o atraso do país, atraso que haverá de ser, algum dia, absorvido pelas forças civilizatórias do progresso. Paisagem que rememora as origens e que projeta no futuro as possibilidades de sua redenção, a pobreza não se atualiza como presente, ou melhor, na imagem do atraso, aparece como sinal de ausência.

A pobreza tornada paisagem, emoldurada como natureza morta, como "sinal de ausência", não afetaria, ou deslocaria de lugar, quem a contempla. Do Beco, compaixão e generosidade não atraíram o poeta. Bandeira retira da moldura trabalhadores, malandros, miseráveis, infames. Refuta a carência que os enfraquece impedindo-os de interrogar o presente, de inquirir o tempo que lhes nega intensidade. A pobreza 
como paisagem impediria ao poeta o contágio desnorteante com a alteridade, nada aconteceria, somente a encenação pública de histórias definitivamente encerradas.

Manuel Bandeira, no conciso poema, recusa eleger os excluídos como heróis urbanos, personagens sacralizados em suas misérias. O desejo do poeta seria o de profanar a paisagem deificada pela natureza; almeja, dessa profanação, intensificar a vida tensa e inconclusa da cidade feita de cortes, passagens, entrelaçamentos de histórias sem fim. O Beco mostra-se como uma lâmina fria, cortante, ao recusar o olhar do Sujeito hermeneuta que contempla suas sombras e luzes projetadas no mundo. Na rua estreita da Lapa, tensões insolúveis revidam o olhar à procura de conclusões às tramas urbanas. Revidam o olhar como o fio de uma navalha tornando o Rio de janeiro estranho aos limites das suas bordas. Do Beco, a cidade se fragmenta, multiplica-se, desdobra-se incansavelmente. Para que serve a cidade?

A cidade não serve para nada, quando verdades do Sujeito e do mundo recusam-se a perder a estabilidade dos seus sentidos. Não serve para nada quando do alto de um prédio, como alerta Sebastião Uchoa Leite, ou de um aeroplano, segundo Benjamin, o olhar é indiferente ao lugar indeterminado, sem pouso fixo dos modos fascistas de existir. Barbárie, nem sempre visível, que se espraia pela urbe enfraquecendo a força do corte de uma navalha.

\section{REFERÊNCIAS}

BANDEIRA, M. Libertinagem \& Estrela da Manhã. Nanterre: Allca XX, 1998.

BENJAMIN, W. Charles Baudelaire: um lírico no auge do capitalismo. São Paulo: Brasiliense, 1989. (Obras Escolhidas, v. 3).

BENJAMIN, W. Magia e técnica, arte e política: ensaios sobre literatura e história da cultura. São Paulo: Brasiliense, 1996. (Obras escolhidas, v. 1).

BENJAMIN, W. Rua de mão única. São Paulo: Brasiliense, 1987. (Obras escolhidas, v. 2).

BENJAMIN, W. Rua de sentido único. Lisboa: Assírio \& Alvim, 2004. 
CAMILOTTI, V. C. João do Rio: idéias sem lugar. Uberlândia: EDUFU, 2008.

CERTEAU, M. A invenção do cotidiano: artes de fazer. Petrópolis: Vozes, 1998.

GAGNEBIN, J. M. Limiar, aura e rememoração: ensaios sobre Walter Benjamin. São Paulo: Editora 34, 2014.

GAGNEBIN, J. M. Posfácio. In: ARAGON, L. O camponês de Paris. Tradução de Flávia Nascimento. Rio de Janeiro: Imago, 1986.

GAGNEBIN, J. M. Sete aulas sobre linguagem, memória e história. Rio de janeiro: Imago, 1997.

LEITE, S. U. Obras em dobras. São Paulo: Duas Cidades, 1988.

RIO, J. A Alma encantadora das ruas. Rio de Janeiro: Secretaria Municipal de Cultura, 1991.

VIEIRA, E. A cidade e o governo dos homens: sobre o lastro educacional da urbanidade contemporânea. 2012. Dissertação (Mestrado em Educação) Faculdade de Educação, Universidade de São Paulo, São Paulo, 2012.

WALTY, I. L. Anonimato e resistência em Eles eram muitos cavalos, de Luiz Ruffato. In: HARRISON, M. (org.). Uma cidade em camadas: ensaios sobre o romance Eles eram muitos cavalos de Luiz Ruffato. São Paulo: Horizonte, 2007. 



\section{Visitando a [categoria] cidade em diálogos com corpo e alimentação}

MARIA LÚCIA MAGALHÃES BOSI

Esta obra nasce, sobretudo, de um desejo de experimentação, de um olhar curioso acerca do que vem sendo produzido e, mais que isso, do que se apresenta como potencialidade no encontro do campo alimentação e nutrição - e do objeto/conceito corpo - quando dialogam com cidade tomada como categoria analítica. Campo esse marcado por dualidades e tensões, no qual a alimentação interpela e perturba a positividade almejada pela nutrição, ao insistir na inclusão da experiência, da produção subjetiva, do propriamente humano. Movimento que se repete com as categorias corpo e cidade, quando as desloca, respectivamente, do espaço do discurso biomédico e da geografia física, para reconfigurá-las como experiências corpo-mundano; corpo vivido; cidade-mundo. Ou seja, quando o corpo 
ultrapassa a biologia para se apresentar como fenômeno no qual se inscreve o mundo (MERLEAU-PONTY, 1999), a vida, as relações sociais. Considerado sob uma perspectiva política, o corpo se situa "na concretude, enquanto volume materializado, mas sempre resultado de investimentos de poder e de enunciações por parte dos saberes que o montam e o constroem como valor". (VIEIRA; BOSI, 2013, p. 844) E a cidade, por sua vez, ao não se limitar a delineamentos geográficos, se revela como um condensado de vivências, símbolos, experiências; espaço que tanto pode libertar como realizar práticas de controle sobre os corpos de quem nela habita.

A intenção foi reunir aqui estudos sobre corpo e alimentação que, de alguma forma, se imbricam com a questão das cidades, do urbano como experiência, para fazer pensar, explorar possibilidades. Evidenciar diferentes modos de ver a cidade sob aproximações teóricas interdisciplinares. Portanto, cabe, logo de início, esclarecer que, como exercício exploratório, não buscamos um consolidado teórico, haja vista a quase ausência dessa discussão no campo alimentação e nutrição. Nossa intenção foi incentivar um começo de conversa com uma categoria que opera como transconceito, uma vez que já vem sendo, há tempos, objeto de atenção de diferentes áreas, notadamente, Planejamento Urbano; Geografia; Psicologia; Sociologia; Antropologia; Engenharia(s)... Mas com escassa produção no que se refere à articulação teórica nos campos Saúde e AlimentaçãoNutrição. Isso, não obstante a questão urbana atravessar uma infinidade de fenômenos nesses campos. Quais interfaces da categoria cidade com estudos sobre corpo e alimentação?

Concordando com Sánchez (2001, p. 33), “O tema das leituras da cidade é de interesse em [...] abordagens do campo simbólico". Sendo a alimentação uma instância fundamental de realização da produção simbólica e que se desdobra nos corpos, como imagem e valor, indispensáveis para entender esses fenômenos são investigações

que penetre $(\mathrm{m})$ no significado íntimo da vida especificamente moderna e seus produtos [...] por assim dizer [que busquem] resolver a equação que estruturas como a metrópole dispõem entre os conteúdos individual e superindividual da vida. (SIMMEL, 1979, p. 1) 
Refletindo sobre um formato com que pudéssemos introduzir ao leitor este livro como totalidade articulada, em suas diferentes nuances, numa perspectiva de religação consoante o pensar complexo (MORIN, 2003) que aqui opera numa "posição" meta teórica, construímos um mosaico. Melhor dizendo, uma bricolagem, desdobrando um passeio pela obra, ao modo de uma visita, daí o título, na qual conversamos rapidamente com cada autor(a), contemplando seu capítulo como quem contempla uma pintura. Produziu-se, então, uma intertextualidade, espécie de trama (ou bordado) com os fios da nossa construção e de autores que nos inspiram, entrelaçados com trechos que nos impactaram em cada capítulo desta obra, cuja localização iremos indicando, caso o leitor queira visitá-los de forma mais imediata no corpo do livro. Desse exercício, que também pode ser entendido, consoante a metáfora de Costa, Dimenstein e Leite, feita no capítulo 2, como "um mapa às avessas, que nos ajuda a nos perdermos nos emaranhados da cidade [como categoria], buscando acompanhar os diversos processos que se desenrolam no contexto estudado", deriva o texto desta introdução. Desse modo, recuperando aspectos teóricos que podem inspirar outros exercícios.

As cidades, como se verá, aparecem neste livro ora como cenários nos quais as relações dos sujeitos acontecem, ora de forma mais densa, como categoria analítica, englobando experiências construídas no cotidiano, evidenciando que "o processo de produção do espaço social é ao mesmo tempo objetivo e subjetivo". (SÁNCHEZ, 2001, p. 33) E é nessa tessitura que seus espaços de poder, o público e o privado, as exclusões e inclusões sociais, dentre inúmeras outras questões, se mesclam e se constituem. Mas, antes de tudo, a intencionalidade aqui, no sentido fenomenológico, é convocar a cidade - sinônimo de urbano, urbanidade - como categoria estratégica no campo dos estudos de corpo e alimentação, como uma vertente teórico-metodológica nesta teia de saberes, a nosso ver, ainda pouco explorada. Sobretudo, num momento em que, como destaca Costa, Dimenstein e Leite, no capítulo 2, "pela primeira vez na história, mais da metade da população mundial vive nas cidades". Assim, faz-se necessário considerar "uma problemática especificamente 
urbana na agenda das considerações teóricas”. (SOJA, 1993, p. 118) E um referencial no qual a experiência urbana se situe como cerne de muitos fenômenos, a exemplo daqueles que se desdobram no corpo, na alimentação, na saúde.

Mudanças tão profundas na vida urbana demandam novas perspectivas teóricas e novos modelos de inteligibilidade para descrevê-las. Publicações recentes testemunham isso e focalizam-se cada vez mais na percepção, na paisagem, nas sensações, no corpo, nas ambiências e em outros termos diretamente relacionados às experiências comuns dos habitantes da cidade. (THIBAUD, 2012, p. 3)

Nesse escopo, sujeito e estrutura se misturam produzindo experiências tecidas na materialidade da vida urbana. Concordamos com Costa, Dimenstein e Leite, quando postulam, no segundo capítulo, ser "impossível pensar a subjetividade humana contemporânea separada da experiência urbana”. Entendem-se, portanto, as cidades não apenas como um cenário no qual as relações entre atores e os fenômenos sociais podem ser observadas em sua dimensão concreta, mas como conceito que articula um quadro teórico específico que permite compreender o urbana também como experiência. Assim, ao considerar o espaço como produção social e política, não cabe falar somente de "territórios", da forma como essa categoria, grosso modo, se operacionaliza nos discursos da gestão e da planificação em saúde (coletiva) - ainda que a noção/ conceito de território possa englobar os planos material e subjetivo, articulando o singular com o coletivo. Da mesma forma, (meio) ambiente, outra categoria recorrente nas narrativas e análises sobre a produção de espaço e a produção da saúde nos diferentes espaços, revela uma falta no que concerne a certos fenômenos e dimensões, mesmo quando iluminada por aproximações histórico-críticas.

Cabe reconhecer que o termo "(meio) ambiente" ou "ambiente", como vem sendo cada vez mais empregado, não se vincula e se restringe ao que conhecemos como "mundo natural". Contudo, sua operacionalização nas análises em saúde, quando escapa à naturalização, ainda se orienta, preponderantemente, por macronarrativas que excluem a 
dimensão estética, o sensível. Não obstante ressalvas de várias ordens, isso leva certos autores a virem investindo conceitualmente e desenvolvendo estudos orientados pela instigante noção de ambiência:

definida como o espaço-tempo experimentado pelos sentidos. Mais qualitativo e aberto, esse novo modelo de inteligibilidade da noção de ambiência foi sendo lapidado ao longo do tempo e desenvolveu suas próprias categorias de análise [...] A noção de ambiência restitui o lugar dos sentidos na experiência dos espaços vividos; ela permite caracterizar nossas formas de experienciar a vida urbana. (THIBAUD, 2012, p. 10)

Tais categorias, território e ambiente, quando usadas no campo da saúde, ao que nos parece, precisam se aproximar do que se processa na microfísica do cotidiano, ou seja, das cidades e seus lugares.

Em uma época em que os problemas ambientais despontam com urgência e força, e em que o caráter público dos espaços urbanos é crescentemente questionado, nos parece mais importante do que nunca embarcar em reflexões profundas sobre a cidade sensível. [...] não porque seja necessário acrescentar mais uma camada de dificuldades aos problemas energéticos, climáticos, políticos [...] mas, sim, porque se trata da nossa própria maneira de habitar o mundo urbano, de como nos encaixamos e o experimentamos no nosso cotidiano. (THIBAUD, 2012, p. 4, grifo nosso)

Desse modo, importam, também, lugares e, fundamentalmente, o espaço como experiência que a categoria cidade pode resgatar: "a cidade é habitada por histórias fragmentadas produzidas por forças que desafiam a racionalidade dos cálculos construídos no cotidiano", como nos lembra Luis Antonio Baptista, nas páginas do prefácio deste livro. Vivemos numa cidade, nascemos numa cidade, construímos laços e identidades com cidades (e lugares). Para ilustrar de forma mais clara: não falo "Nasci naquele território" ou "Nasci no ambiente tal", mas numa cidade-lugar, tecida por "lugares de memória”, como diria Norá (1981), e por lugares antropológicos, como nos sugere Augé (2005), que faz com que identidades se misturem, se constituam mutuamente.

Assim, importa uma "ecologia urbana dos sentidos que forneça acesso ao contexto estético da experiência comum” (THIBAUD, 
2012, p. 6), que nos auxilie a compreender, no nosso campo de interesse, a alimentação como experiência e o corpo como produção social. É preciso, ainda, considerar os lugares como espaços “repletos de diferenças internas e conflitos, que podem ser expressos em leituras dissonantes e em disputa de espaço político". (SÁNCHEZ, 2001, p. 37) Assim, questões de natureza estética não mais se apresentam como secundárias ou subordinadas; ao contrário, vêm ocupando o cerne ou configurando um elemento central e estratégico no pensamento urbano contemporâneo, onde o corpo e os sentidos passam a ser considerados.

Cidade é uma categoria forte e que consideramos mais refinada teoricamente para certas análises e aproximações mais sutis; há de fato "uma problemática especificamente urbana” que precisa ser recuperada nos estudos sobre saúde, corpo e alimentação. Não por acaso, no capítulo 3, Calabrese e Amparo-Santos aludem a DaMatta (1987) no que o autor nomeia "gramática dos espaços", que diz respeito "a esses diversos espaços [pertencentes] a esferas de significação [...] que constituem a própria realidade [...] locais [que] possuem agência no pensar e no comportar dos sujeitos". Cidade é uma categoria capaz de recuperar essas dimensões. É, portanto, produto e produtora de vivências, narrativas, subjetividades, afetividades, memórias e lembranças, que se entrelaçam, num movimento sem fim, conforme dito no prefácio: "A urbe oferece uma tensão insolúvel, ensejada pela 'máquina humana viva, a mecânica da vida concreta', da qual sóbrias ideias, projetos são produzidos, testados e destruídos infinitamente".

Nesse movimento, no campo a que vinculamos a categoria cidade nesta obra, sustentamos que as complexas experiências humanas na vida urbana atuam como determinante social em saúde, com todas as ressalvas que o termo "determinante" exige, se quisermos nos manter congruentes com um pensar complexo e dialético. Mas, ainda se adotarmos essa terminologia, essa determinação não deve ser tomada como um conjunto de variáveis ou "fatores causais", como aponta o capítulo 1: é totalidade que não pode ser desmembrada para efeitos analíticos - "cidade e 
saúde constituem complexidades em sinergia [...] a cidade [é] categoria complexa, do mesmo modo que saúde, nas quais se articulam dimensões subjetivas e expressões materiais, estrutura e sujeito".

Pensamos, sobretudo, no esforço de produção da vida nas metrópoles contemporâneas, com seu ritmo cada vez mais veloz, marcadas pelo individualismo, medo e pela solidão, conhecidos "determinantes sociais" de tantas enfermidades. No campo da alimentação, análises com as que figuram neste livro ilustram como as transformações ocasionadas pelas novas tecnologias levaram a um fenômeno urbano visível, conforme dito no capítulo 5:

novos arranjos da comensalidade que hoje, cada vez mais, incorporam as lógicas das mudanças ocorridas no universo da informação, da tecnologia e das redes sociais. A possibilidade de sentar para comer em uma mesma mesa embora cada um esteja conversando com outras pessoas ou em contato com informações de outros lugares, coloca em cena outra comensalidade e um novo conceito de sociabilidade.

Essas mudanças estão associadas a transformações na "arquitetura social da cidade" mediante processos como gentrificação que, não por acaso, penalizam trabalhadores precarizados, desempregados, imigrantes, sem-teto e todos aqueles que perturbam o projeto modernizador das cidades, com impactos notáveis na saúde e alimentação. Esse processo possibilita expulsar as populações pobres de áreas centrais que a produção das cidades-mercadoria não admite como empecilho ao encarecimento que produzem no espaço e aos lucros que dele obtém. A gentrificação resulta na valorização de certas áreas da cidade, com reflexos nos segmentos que nela habitam, em detrimento de outros, evidenciando a relação entre cultura e a reprodução de processos de inclusão e de exclusão social (SÁNCHEZ, 2001), não podendo ser um fenômeno isolado das análises que tomam corpo e alimentação como objetos, pelos efeitos simbólicos que tal displacement produz.

estudos [sobre] corpo influenciaram os estudos urbanos [...] corpo e cidade se configuram mutuamente [...] além de os corpos ficarem inscri- 
tos e contribuírem para a formulação do traçado de cidades, as memórias das cidades também ficam inscritas e contribuem para a configuração de nossos corpos. A cidade é percebida pelo corpo como conjunto de condições interativas e o corpo expressa a síntese dessa interação descrevendo, em sua corporalidade, o que passamos a chamar de 'corpografia' urbana. (BRITTO; JACQUES, 2009, p. 4)

Conforme asseveram Oliveira, Czeresnia e Vargas, no capítulo 4, "o corpo contemporâneo se transformou progressivamente em referencial para a construção das identidades pessoais, nos quais atributos físicos determinam e marcam a definição de um lugar no mundo". E, referenciando-se em Agier (2011), prosseguem: "o 'viver na cidade' constitui parte e expressão de fenômenos complexos como as relações de identidade, etnicidade, territorialidade, globalização, lugares, fronteiras, situações às margens etc.”.

Sabemos que há um complexo intercâmbio entre a transformação material e o simbolismo cultural. Os lugares se reestruturam, as identidades se reconfiguram: "a cultura é o meio que relaciona a textura da paisagem ao texto social”. (SÁNCHEZ, 2001, p. 35) Assim, como dito no capítulo 5, "transformações globais mais amplas da cultura impactam o 'local e o cotidiano' ressignificando modos de viver e sentidos atribuídos às experiências locais, de todo modo cultural”. Desse modo, local e global se aproximam, permitindo compreender os efeitos de homogeneização cultural, bem como a articulação entre esses planos de análise, melhor dizendo, sua integração. Giddens (1991, p. 177) adverte:

a globalização não significa tão somente uma intensificação das relações sociais em escala mundial, uma vez que integra diferentes contextos sociais. Em realidade, esse movimento, geralmente, figura de maneira insidiosa e silenciosa, transforma espaços locais e, por conseguinte, afeta as intimidades da existência pessoal, pois atua de forma a modificar a vida cotidiana.

Podemos falar assim numa globalização dos modelos de corpo e alimentação. Conforme assinalamos em outro espaço (ANDRADE; BOSI, 2003), como marca distintiva desse fenômeno (globalização), 
convivemos com informações veiculadas sob a urgência do tempo, num ritmo frenético que dificulta, quando não impossibilita, a assimilação pelo desdobramento da reflexão. Com isso, a comunicação é instantânea, porque é seu próprio simulacro, haja vista que, em certo sentido, não existe, convidando-nos à análise das forças visíveis e invisíveis na produção no imaginário em esferas como o comer e a construção social dos ideais de corpo.

Não vou entrar nos detalhes da análise das estruturas invisíveis - que são um pouco, como a força da gravidade, coisas que ninguém vê, mas é preciso supor para compreender o que se passa - às experiências individuais, isto é, como relações de forças invisíveis vão se retraduzir em conflitos pessoais, em escolhas existenciais. (BOURDIEU, 1997, p. 75)

Nesse cenário, "os alimentos estão sendo continuamente reinterpretados, reinventados, sendo alguns excluídos outros reintroduzidos e outros ainda transformados, a fim de se adequarem às exigências da vida urbana e acelerada", conforme aponta o capítulo 5. Neste ponto, parece-nos útil retomar o conceito de habitus proposto por Bourdieu (2011) para indagarmos o lugar da cultura e sua relação com a ação dos sujeitos. Um habitus é uma disposição, um conjunto de esquemas interiorizados inscritos no próprio corpo, que retrata a dimensão corporal de um aprendizado decorrente da socialização. Processo de produção e formatação de subjetividades no qual se espraiam valores que se tornam, cada vez mais, dominantes - entenda-se, aqueles que aderem à lógica da sociedade de consumo, no capitalismo mundializado, tendo a mídia, no sentido amplo, como aliada englobando todos os "dispositivos", que operam como rede, tal como propõe Agamben (2009) referenciando Foucault.

Não queremos com isso advogar por uma dominação absoluta, sem reconhecer resistências. Contudo, a máquina midiática num consórcio com a produção inesgotável de mercadorias alicerçadas na ciência e na tecnologia tem potência e, via de regra, consegue incorporar como suas pautas de organizações governamentais e não governamentais, de 
movimentos sociais autônomos em seu nascedouro, e mesmo revolucionários, vis-à-vis a ética da sociedade de consumo, convertendo-as em commodities. Cabe reconhecer a forte assimetria nas relações de poder entre as instâncias, numa disputa de narrativas alicerçada em relações de poder bastante assimétricas. Esse processo se consolida, sobretudo, no espaço urbano e nos auxilia na compreensão das interfaces cidade-corpo-alimentação e seus desdobramentos políticos.

As pautas sobre alimentação repercutem sensibilidades, demandam representações existentes no imaginário coletivo e tomam o espaço urbano e as mídias ininterruptamente "[...] o fenômeno da transmidialidade presente na cultura contemporânea, em que tanto mídias quanto as narrativas interagem e entrelaçam seus conteúdos". (JENKINS, 2006) O entrelaçamento entre a comunicação, a nutrição e as práticas de consumo realçam a presença transversal da subjetividade nas questões sobre o saudável, sobretudo na cidade, conforme dito no capítulo 5: “[...] levantar esta reflexão permite trabalhar com o poder e o alcance das subjetividades e afetividades [...] inscritas no imaginário das urbes".

Essas capturas incidem sobre um extenso conjunto de elementos no imaginário social urbano sobre alimentação e nutrição, produzindo o mercado fitness, academias, expansão de consultórios de nutrição, não raro espaços onde se estimula a venda de suplementos, probióticos e um sem números de "aditivos" à dietética tradicional, construída, como se sabe, com alimentos acessíveis. Em torno disso, impressiona a proliferação de lojas especializadas e farmácias de manipulação onde se fabricam as mercadorias que respondem às necessidades geradas pelo discurso do "saudável", "natural" e outros modismos.

Já em torno do corpo-mercadoria, se somarão incontáveis outros recursos, como a cosmética e a indústria médico-estética com seu arsenal de próteses e artefatos, gerando um mercado monumental mediante a expansão dos procedimentos estéticos de toda ordem, notadamente cirurgias plásticas, impulsionadas pelos ideais de corpo manipulados pelas tecnologias de imagem. Desse modo, vendem a perfeição corporal e a juventude eterna como possibilidades e mesmo responsabilidade 
individual, cujo valor inflaciona na "sociedade do espetáculo" (DEBORD, 2000) com seus outdoors, revistas, vitrines digitais em que a espetacularização da vida se desdobra, com seus disfarces, encenações, inautenticidades. É também a "sociedade da transparência" de que nos fala Byung-Chul Han (2017, p. 25, tradução nossa), na qual:

cada sujeito é seu próprio objeto publicitário. Tudo se mede tomando como base seu valor de exposição [...] tudo se volta para o exterior, revelado, desnudado, despido e exposto. O excesso de exposição transforma tudo em mercadoria [...] A economia capitalista acaba por submeter tudo a essa obrigação de se expor.

Nem mesmo movimentos que em seu nascedouro se apresentam como "fato social total" (MAUSS, 1997) vinculado a "ambições morais superiores", conforme recupera Celka, analisando, no capítulo 7, o estilo vegano, escapam a essa captura. Em sua análise sobre esse movimento, nos damos conta da expansão de um modo de vida originalmente ascético, reservado a uma elite militante fundada num conhecimento bastante complexo e refinado cuja operacionalização no cotidiano não se revela como um processo de fácil execução. Contudo, indaga Celka: "na experiência urbana [...] o modo do veganismo se metamorfoseou em atitude cool. De qual sensibilidade coletiva esse estilo é expressão? O que ele nos diz sobre nossas práticas urbanas contemporâneas?”. E acrescento: o que ele nos diz sobre a conexão global-local a que antes aludimos?

A cidade como questão entra em níveis diferentes neste livro, desvelando, na interface com os objetos corpo e alimentação, problemáticas emergentes em cenários urbanos ibero-americanos, na contemporaneidade. Nosso propósito é incentivar um caminhar dos "cenários" para a construção de um diálogo com o vasto acervo transdisciplinar erigido mediante essa categoria, o urbano, de modo a dispormos de um arcabouço teórico capaz de situar os objetos do campo alimentação e nutrição num referencial ainda inédito nesse espaço. A visita a esta obra possibilita localizar conceitos estratégicos para pensar a alimentação e o corpo no urbano nessa direção: espetacularização urbana; urbanidade; 
desterritorialização; direito à cidade; cidades sensíveis; alma da rua; modelizações dominantes na cidade; novas urbanidades; lugares de memória; lugares antropológicos; corpo-território; cidade-mercadoria; corpo-mercadoria; gentrificação; corpo vivido... Os conceitos são muitos e se distendem pelas páginas desta produção coletiva. Também se desvelam nos estudos em contextos urbanos diversos orientados pelo enfoque qualitativo aqui compartilhado.

São muitos os estímulos e as contribuições que recolhemos nessa visita interativa à obra. Ao final do percurso, reafirmaram-se para nós a natureza complexa do urbano, como objeto e categoria analítica, as potencialidades no campo alimentação e nutrição, as incontáveis dimensões daquilo que é "tecido junto" que se desvela-velando, se antecipa como insurgência, se anuncia no silêncio, se oculta nos discursos, desafia nosso olhar, se esconde nas texturas. E retornou-nos um excerto poético que sintetiza nossa leitura: "As cidades, assim como as florestas, têm seus antros nos quais se esconde tudo...”. (VICTOR HUGO)

\section{REFERÊNCIAS}

AGAMBEN, G. O que é o contemporâneo? E outros ensaios. Chapecó: Argos, 2009.

AGIER, M. Antropologia da cidade: lugares, situações, movimentos. São Paulo: Terceiro Nome, 2011.

ANDRADE, A.; BOSI, M. L. M. Mídia e subjetividade: impacto no comportamento alimentar feminino. Revista de Nutrição, Campinas, v. 16, n. 1, p. 117-125, jan./mar. 2003.

AUGÉ, M. Não-lugares: introdução a uma antropologia da sobremodernidade. Lisboa: ed. 90 graus, 2005.

BOURDIEU, P. O senso prático. 2. ed. Petrópolis: Vozes, 2011.

BOURDIEU, P. Sobre a televisão: seguido de A influência do jornalismo e Os Jogos Olímpicos. Rio de Janeiro: Zahar, 1997. 
BRITTO, F. D.; JACQUES, P. B. Corpocidade: arte enquanto microresistência urbana. Fractal, Revista de Psicologia, Rio de Janeiro, v. 21, n. 2, p. 337-349, maio/ago. 2009. Disponível em: http://dx.doi.org/10.1590/ S1984-02922009000200010.

DAMATTA, R. A casa e a rua: espaço, cidadania, mulher e morte no Brasil. Rio de Janeiro: Guanabara, 1987.

GIDDENS, A. As conseqüências da modernidade. São Paulo: UNESP, 1991. GUY, D. A sociedade do espetáculo. Rio de Janeiro: Contraponto, 2000.

HAN, B.-C. La societé de la transparence. Paris: Presses Universitaires de France, 2017.

JENKINS, H. Convergence culture. New York: New York University Press, 2006.

MAUSS, M. Sociologie et anthropologie. Paris: PUF, 1997.

MERLEAU-PONTY, M. Fenomenologia da percepção. Tradução de Carlos Alberto Ribeiro de Moura. 2. ed. São Paulo: Martins Fontes, 1999.

MORIN, E. A cabeça bem-feita: repensar a reforma, reformar o pensamento. Tradução de Eloá Jacobina. 8. ed. Rio de Janeiro: Betrand Brasil, 2003.

NORA, P. Entre memória e história: a problemática dos lugares. Projeto História, São Paulo, v. 10, p. 7-28, 1993.

SÁNCHEZ, F. A reinvenção das cidades na virada de século: agentes, estratégias e escalas de ação política. Revista de Sociologia e Política, Curitiba, n. 16, p. 31-49, jun. 2001.

SIMMEL, G. A metrópole e a vida mental. In: VELHO, O. (org.). O fenômeno urbano. Rio de Janeiro: Jorge Zahar, 1979.

SOJA, E. W. Geografias pós-modernas: a reafirmação do espaço na teoria social. Tradução de Vera Ribeiro. 2. ed. Rio de Janeiro: Jorge Zahar, 1993. THIBAUD, J.-P. A cidade através dos sentidos. Cadernos PROARQ, Rio de Janeiro, n. 18, 2012.

VIEIRA, C. A. L.; BOSI, M. L. M. Corpos em confecção: considerações sobre os dispositivos científico e midiático em revistas de beleza feminina. Physis: Revista de Saúde Coletiva, Rio de Janeiro, v. 23, n. 3, p. 843-861, 2013. 



\section{Arte na cidade inspirações para os campos da saúde e alimentação}

MARIA LÚCIA MAGALHÃES BOSI E ISABELA MAGALHÃES BOSI

\section{INTRODUÇÃO}

Se concebermos, consoante o pensar complexo (MORIN, 2006), a inseparabilidade entre ser humano e mundo, que o mundo que construímos nos constrói simultaneamente (MERLEAU-PONTY, 1999), podemos vislumbrar intervenções artísticas no espaço urbano como potenciais agentes de humanização da cidade e das práticas que nela se desenvolvem. Produzir saúde no espaço das cidades, promovendo a inclusão e diminuindo os desníveis, as iniquidades, convoca novos modos de escuta, sobretudo de grupos em situação de maior vulnerabilidade. A 
cidade, melhor dizendo, o complexo fenômeno das experiências humanas na vida urbana atua como determinante social em saúde, como uma totalidade que não pode ser desmembrada para efeitos analíticos. Cidade e saúde constituem complexidades em sinergia, de onde surge uma das premissas que norteiam este capítulo: cidade é uma categoria complexa, do mesmo modo que saúde, na qual se articulam dimensões subjetivas e expressões materiais, estrutura e sujeito.

É importante sinalizar, aqui, que compreendemos a categoria "cidade" como uma "densa rede simbólica em permanente construção e expansão", como define Armando Silva (2006, p. XXIII, tradução nossa), no livro Imaginários urbanos. Segundo o autor, a cidade é também

um cenário de linguagem, de evocações e sonhos, de imagens, de variadas escrituras. Não devemos estranhar, portanto, que a cidade tenha sido definida como a imagem de um mundo, mas essa ideia se complementaria dizendo que a cidade é, do mesmo modo, o contrário: o mundo de uma imagem, que lenta e coletivamente vai se construindo e voltando a se construir, incessantemente.

Sob essa lente, dialética, sujeito e estrutura se mesclam, produzindo experiências tecidas na materialidade da vida. Ampliando essa reflexão, Silva (2006) acrescenta que uma cidade também se faz por suas “expressões", pela construção de uma "mentalidade urbana", que englobaria os espaços físicos e também os de ficção que nos atravessam diariamente, como cartazes publicitários e graffitis. Afastamo-nos, portanto, da noção de território quando depurada de subjetividade, a qual, grosso modo, orienta a gestão e a planificação em saúde coletiva. Igualmente, a categoria "ambiente" parece conter uma falta no que concerne à dimensão da identidade que a literatura sobre cidade recompõe. Faz-se necessário considerar "uma problemática especificamente urbana [...] na agenda das considerações teóricas e da ação social radical”. (SOJA, 1993, p. 118) 
É nesses "espaços de ficção" - as cidades -, expressão e construção da mentalidade urbana que se inserem as chamadas intervenções urbanas, ou seja, todo tipo de criação artística que interfere no espaço público da cidade, como os próprios graffitis que Silva evoca e diversas outras expressões artísticas. Para o autor, portanto, o que mais diferencia uma cidade de outra - e isso é fácil de constatar - não seria apenas a arquitetura, mas também, e sobretudo, os "símbolos que sobre ela (a cidade) constroem os próprios moradores". (SILVA, 2006)

No que concerne à produção da saúde e da alimentação adequada e à humanização do cuidado nessas esferas, campos em que se move nossa reflexão, a arte pode acionar novas formas de conexão entre a população e os serviços de saúde, ampliando o alcance das ações nas cidades. Podemos afirmar que o direito à cidade se entrelaça com o desafio de garantir o direito à alimentação e à saúde. Basta constatarmos que os processos de gentrificação, não por acaso, penalizam os mesmos segmentos marginalizados no que concerne ao direito à saúde, gerando a perda do que Marc Augé analisa como "lugares antropológicos", onde se instalam sentidos, tecidos na experiência coletivamente partilhada. Esses sentidos se inserem fortemente nas práticas de saúde e alimentação e se articulam com as experiências concretas cotidianas, tecidas nas trocas comunitárias, nos lugares onde habitamos. Conforme observado por Sá (2014, p. 215), “o que parece inquietar Augé é a súbita e rápida substituição dos lugares [antropológicos] pelos não lugares, tornando a cidade cada vez mais um espaço de anonimato e solidão".

Por sua vez, recuperando um termo cunhado pelo filósofo Henri Lefebvre (1968), Harvey (2014, p. 28) assinala:

O direito à cidade é, portanto, muito mais do que um direito de acesso individual ou grupal aos recursos que a cidade incorpora: é um direito de mudar e reinventar a cidade mais de acordo com nossos profundos desejos. Além disso, é um desejo mais coletivo do que individual, uma vez que reinventar a cidade depende, inevitavelmente, do exercício de um poder coletivo sobre o processo de urbanização. A liberdade de fazer e refazer 
a nós mesmos e as nossas cidades [...] é um dos nossos direitos humanos mais preciosos, ainda que um dos mais menosprezados.

Nessa perspectiva, esse direito inclui não somente os modos de vida em sua objetividade - moradia, mobilidade, acessos a bens e serviços -, mas a dialogicidade que permite vocalizar demandas e necessidades, dentre elas, as de saúde. $O$ direito à cidade envolve a garantia de acionar direitos nas cidades, sendo a saúde um deles. Mais do que isso, evoca a cidadania, a participação e o controle social, elementos centrais no ideário da Reforma Sanitária e no Sistema Único de Saúde (SUS) brasileiros. Para tanto, há de abrir um amplo diálogo, uma polifonia que, segundo pensamos, convoca a arte como recurso.

Nesse escopo, diferentes formas de expressão estética podem ser apropriadas ou inspirar não somente, mas também, ações de saúde no contexto da construção do direito à cidade, abrindo vias de acolhimento e diálogo entre os atores, dentre eles, profissionais e usuários dos serviços e programas de saúde, na esteira da garantia da saúde como direito.

Desafia-nos, sobretudo, a inserção de segmentos, grosso modo, pouco contemplados ou mesmo excluídos nos espaços institucionalizados e em dispositivos integrantes da rede de atenção à saúde, a exemplo de usuários de drogas, população LGBT, portadores de enfermidades cujas necessidades são ainda pouco conhecidas e consideradas na planificação de ações voltadas à qualidade na rede de atenção.

No campo da alimentação e nutrição, especificamente, podemos ilustrar com vários estudos que apontam a violência e exclusão sofridas por obesos, notadamente, obesos mórbidos que chegam mesmo a perder o direito a circular na cidade, na qual não encontram espaços de acolhida e suporte. (BOSI; TEIXEIRA, 2016) De outra parte, conforme salientado por Stenzel (2002), o culto à magreza como uma questão ideológica de opressão social e de gênero incentivada por mensagens e outdoors espalhados nas cidades e em seus templos de consumo impelem, sobretudo o grupo feminino e os adolescentes, a ver na magreza uma espécie de passaporte de ascensão social, alienando-os de si mesmos. Stenzel (2002) defende grupos de reflexão voltados a esses segmentos vulneráveis como 
espaços de resistência e de crítica em que questões como essas possam ser aprofundadas. Para tanto, há de investir na inventividade necessária à ativação de dimensões não contempladas na assistência e na educação inspiradas no modelo tradicional. Marcados pelo estigma de que são vítimas, foco de ações biopolíticas, de modalidades de violência, por vezes, muito sutis, mas intensas em seus desdobramentos, como inserir tais segmentos, ou melhor, convidá-los a se inserir? Acreditamos que a arte como linguagem, que pode ser decifrada de forma universal, seja uma via.

Nessa direção, aludir à inserção da arte como recurso em direção à qualidade no âmbito das práticas em alimentação e saúde remete ao que assinala Vieira (2008, p. 24) ao afirmar que "a fusão sistêmica" entre arte, filosofia e ciência, parece ser:

[...] uma fonte de enorme fertilidade na produção da complexidade e, consequentemente, da qualidade de vida [...] Esta última vai depender, na sua efetivação, do natural exercício de capacidades emotivas e afetivas dos elementos humanos envolvidos.

A alusão à complexidade no excerto que acabamos de referir, por sua vez, nos traslada a proposições de Morin (2004, p. 14) que a caracteriza "quando os componentes que constituem um todo [...] são inseparáveis e existe um tecido interdependente, interativo e inter-retroativo entre as partes e o todo, o todo e as partes". Pensar a saúde e alimentação como fenômenos exige essa lente que fraciona e recompõe, resgatando o sujeito neutralizado pelo modelo biomédico, ainda hegemônico nesses campos. Faz emergir o que escapa às quantificações, uma vez que “[...] a complexidade surpreende pela irrealidade, ou, mais que isso, pela invisibilidade do seu conteúdo: é uma noção não-positiva por excelência”. (LE MOIGNE, 1999, p. 49, grifo do autor)

Nessa direção, ações orientadas por um enfoque complexo, notadamente qualitativo, estético, têm muito a iluminar, abrindo possibilidades de ações dirigidas aos enfermos, incorporando a multidimensionalidade da saúde e da alimentação, ao ir além da dimensão técnica do cuidado. 
Como ilustração do que propomos advogar, tomamos aqui para análise um dentre vários projetos de intervenção artística nas cidades, no caso, urbano-poética, realizada na cidade de Fortaleza, Ceará, Nordeste do Brasil, entre outubro de 2013 e janeiro de 2015. Na sequência da apresentação dos traços gerais do que foi essa intervenção, apontamos em que direção essa experiência nos inspira e alguns dentre os vários desdobramentos que vislumbramos no âmbito da práxis em saúde e alimentação, contextualizada na discussão sobre a vida nas cidades.

\section{REVISITANDO A EXPERIÊNCIA}

A intervenção aqui analisada, intitulada "pra você", consistiu, de forma resumida, em envelopes distribuídos nos mais diversos espaços públicos da cidade de Fortaleza, contendo textos íntimos da jornalista e escritora Isabela Bosi, idealizadora dessa intervenção que ela reconhece como "urbano-poética". Durante a execução desse projeto, mais de 200 cartas foram distribuídas pela autora, anonimamente, afixadas em postes, bancos de rua, pontos de ônibus, dentre outros locais da cidade. Sem remetente ou destinatário, apenas com a frase "pra você" carimbada no envelope. Ao final de cada texto, ela colocava o endereço da página do Facebook criada especialmente para o projeto - abertura para uma possível troca, caso a pessoa que encontrasse o envelope desejasse um contato.

Essa ação pode ser compreendida conforme o conceito de "escrita na cidade", definido por Lefebvre (2008, p. 70) como "aquilo que se inscreve e se prescreve em seus muros, na disposição dos lugares e no seu encadeamento". Essa ideia conflui para o que figura no trabalho de Hypolito e Rocha (2013), ainda que relacionado apenas ao graffiti e à pichação. Segundo esses autores, a escrita urbana interfere na "leitura da cidade" pelos sujeitos inseridos nesse contexto. Para eles, essa escrita é executada por grupos que "almejam transformar a realidade social" (HYPOLITO; ROCHA, 2013), o que anuncia um diálogo com movimentos de resistência em outros âmbitos, a exemplo da Reforma Sanitária Brasileira. 
Artistas e cientistas partilham um "núcleo comum" - o ato da criação (VIEIRA, 2008) - capaz de efetivar transformações sociais; mais do que isso: potencializam-se mutuamente, apesar de a modernidade demarcar uma separação estanque entre seus mundos, sendo ainda escassas as alianças, sobretudo no âmbito das intervenções nos vários setores em que incidem políticas públicas. Essa transformação social a que aludimos se dá, no entanto, em níveis mais subjetivos, propondo aos indivíduos novas formas de olhar e pensar os espaços urbanos e estimulando a participação destes na (re)criação da cidade (AZEVEDO, 2013, p. 142), o que evidencia a dimensão política do processo. Essa cidade configura uma "grande malha hipertextual, lugar do acontecimento e da experiência coletiva, espaço em movimento, que se configura e reconfigura de acordo com as ações dos sujeitos que nela habitam". (AZEVEDO, 2013, p. 45)

Silva (2006), em seu livro Imaginários urbanos, defende que o ambiente da cidade e seus usos operam em níveis sutis do indivíduo. Segundo o autor, "o físico produz efeitos no simbólico" do sujeito (SILVA, 2006, p. 20), que se manifestam de diferentes formas. Existe, assim, uma "inseparabilidade entre ser humano e mundo" (ARAÚJO, 2007, p. 23), o mundo que construímos também nos constrói, simultaneamente. E mais, como assinala Merleau-Ponty (1999, p. 5-6):

O mundo está ali antes de qualquer análise que [se] possa fazer dele [...]. O mundo não é um objeto do qual possuo comigo a lei da constituição; ele é o meio natural e o campo de todos os meus pensamentos e de todas as minhas percepções explícitas.

Nessa perspectiva, as cidades são mundos.

Andrea Tavares, em seu artigo "Ficções urbanas: estratégias para a ocupação das cidades", sustenta que a arte urbana proporciona "brechas na realidade" e "suspensão do tempo contínuo", em contraste com trabalhos expostos em museus e galerias, onde o visitante já chega "predisposto a uma experiência estética, já suspendeu o tempo do seu cotidiano para entrar em outra situação, a da arte". Sendo assim, as intervenções urbanas inscritas no corpo da cidade se relacionam com as pessoas que 
passam por elas e, segundo Tavares, essas pessoas respondem, dando "continuidade e movimento" a essas criações artísticas.

Nesse contexto, intervenções artísticas no espaço urbano funcionariam também como uma espécie de dispositivo que desloca o sujeito do momento presente para outros tempos, de um passado (memória) ou mesmo de reinvenção da temporalidade, intervindo no cotidiano e abrindo perspectivas políticas, em direção a novos modos de vida e de relação com o espaço e demais atores.

Ao longo dos dois anos de realização do projeto "pra você", alguns depoimentos foram postados no Facebook. Poucas pessoas responderam às cartas encontradas. Destas, a maioria solicitou explicitamente que mais textos fossem deixados no mesmo lugar para elas. No entanto, grande parte das mensagens recebidas veio de pessoas que ainda não haviam encontrado as cartas, mas que, sabendo por outras pessoas da intervenção, alimentavam um forte desejo de encontrá-las. Esse surpreendente movimento evidencia o impacto que a intervenção causou em algumas pessoas e na relação destas com a própria cidade, que agora se apresentava como espaço de novas possibilidades.

O projeto ganhou repercussões expressivas, virando pauta de matérias em jornais, revistas e mesmo programas televisivos de alcance nacional. Nesses espaços, reiterava-se o mesmo desejo de encontrar uma das mensagens, levantando questões como: o que uma carta, posta anonimamente no meio da rua, pode evocar em uma pessoa? De que maneira uma intervenção urbana pode acessar lembranças e mobilizar sentimentos? Poderia esse tipo de intervenção modificar a relação do indivíduo com o espaço urbano e com esferas específicas do seu modo de viver?

Essas questões começaram a emergir em nossas reflexões, incitando-nos a pensar sobre como esse movimento se entrelaça com o viver na cidade, como se inscreve no contexto do jogo político existente no espaço urbano contemporâneo, povoado por distintos interesses, em torno dos quais vão se constituindo o viver na cidade como direito, o direito à saúde, o direito à vida. Especialmente, se considerarmos que a cidade, como defende Paul Virilio (1998), em entrevista 
concedida a Laymert Garcia dos Santos, "está perdendo sua função de socialização". Virilio (1998) chama atenção para o fato de que, com a Revolução Industrial, a composição das famílias - que antes eram grandes, podendo incluir pessoas não consanguíneas - se torna "nuclear", ou seja, formada somente por pais e filhos. A metrópole vai crescendo e essas famílias se desintegrando, "ao ponto de termos um homem ou uma mulher sozinha, ou seja, um átomo”. (VIRILIO, 1998)

Diante da vida em uma cidade que já não cumpre o papel de socializar, reconduzindo-nos ao esvaziamento dos "lugares antropológicos", tal como figura em Augé (2005), onde cada vez mais somos átomos em vez de grupos, a relação que as pessoas estabelecem com intervenções urbanas que provocam algum contato, como o projeto "pra você", ganha um significado ainda maior, de algum desejo de troca, de encontro, alguma recomposição, talvez.

Em síntese, observamos como essa intervenção urbana - que tomamos, conforme dito, como ilustração de experiências de arte na cidade - pode movimentar lembranças, sensações e, sobretudo, ações de indivíduos; provocando uma reflexão acerca de se e de que formas essas cartas podem ser (re)significadas pelas pessoas, abrindo espaço para novas interações com a cidade, projetualidades e devires.

\section{EM QUE ESSE PROJETO NOS INSPIRA?}

Observar esse projeto e a surpreendente reação por ele gerada, ainda que inscrito em e direcionado a um âmbito distinto do que se considera "área da saúde" ou da " alimentação-nutrição", nos inspirou na direção de pensar - no lastro de atores que vem ensaiando e experimentando essa via - sobre as potencialidades de intervenções artísticas no espaço urbano, ainda que sem a mesma natureza poética ou literária, em práticas voltadas à promoção da equidade e da qualidade do cuidado em saúde, sobretudo nas dimensões humanização e integralidade. Princípios que se inserem no ideário do SUS e se alinham à dimensão ético política do discurso da Segurança Alimentar e Nutricional (SAN). 
Pensamos, sobretudo, nas metrópoles, marcadas pela vida veloz, pelo fluxo impessoal de comunicação, pelo individualismo, pelo medo e, não raro, pelo desamparo e pela solidão, conhecidos determinantes sociais de tantas enfermidades, notadamente em saúde mental, mas não apenas nessa esfera.

Certamente, as potencialidades da arte na cidade são muitas e múltiplas nesses campos aqui focalizados, sendo difícil esgotá-las. Assim, apresentaremos, na sequência, a título de ilustração, dados os limites e as pretensões deste capítulo, esboços de algumas ideias decorrentes do contato com essa experiência, direcionadas a âmbitos distintos que ocupam o discurso e a práxis nos campos: à esfera da educação em saúde/ alimentação; à dimensão da humanização e ao desafio da avaliação como ferramenta da gestão. Portanto, três âmbitos que constituem espaços da práxis da alimentação e nutrição, como componente da saúde em sua dimensão coletiva.

Começando pelo que convencionalmente conhecemos como educação em saúde, intervenções como o "pra você", atraindo o interesse da mídia, das redes sociais e da gestão pública, tal como se deu no caso em tela, poderiam ser apropriadas, superando os formatos tradicionais das ações em saúde, em especial as educativas, grosso modo, restritas ao repasse de informações em folhetos contendo informações em linguagem técnica, sem ressonância na dimensão afetiva e estética da população, enferma ou sadia, reproduzindo o que predomina na formação dos profissionais. Nesse sentido, Vieira (2008, p. 23) adverte ser:

[...] necessário criar gerações sensíveis à realidade, que saibam buscar e estocar informação e estabelecer uma memória complexa, que envolve não só o que é ensinado na escola ou que possa ser lido ou assistido em um aparelho de televisão [ou, acrescentamos, no fluxo frenético das redes sociais], mas o que possa ser vivenciado em nível de emoção, sentimento, afetividade e valores.

Impõe-se, portanto, uma estética na educação que possa tocar esses níveis. Refletindo sobre o "pra você”, ficamos imaginando a distribuição de cartas, em vários pontos da cidade, direcionadas a segmentos 
específicos - hipertensos, soropositivos, diabéticos, pessoas enfrentando protocolos complexos como os vários tipos de câncer - em um estilo evocativo, artístico, mais singular e menos técnico, com linguagem e imagens adaptadas aos repertórios culturais - ou rodas de leitura desses textos nas quais se abrisse uma "conversa na cidade", em lugar das desgastadas sessões educativas -, aproximando usuários dos trabalhadores em saúde que se inserem nas linhas de cuidado na rede pública (e privada) de serviços. Conversa (presencial ou não) na qual se poderia informá-los e lhes perguntar sobre dúvidas, opiniões, sugestões, dificuldades, mediada pela intervenção, pela arte.

Mais do que isso, amparados pelas novas tecnologias, tantas vezes utilizadas para compor extensos - e, por vezes, ineficazes bancos de dados, quem sabe possamos construir um "observatório subjetivo" no qual diálogos se instalassem e novas práticas educativas pudessem emergir, a exemplo da conversa no Facebook, disparada pela intervenção "pra você". Tal dispositivo demandaria articular alianças entre campos atualmente isolados, gerando interdisciplinaridade, transculturalidade e interprofissionalismo, retomando o que antes referimos quanto à fusão Ciência-Arte-Filosofia e à complexidade.

Aderir ao pensar complexo a que logo de início aludimos e dialogar com o campo artístico implica ultrapassar a dimensão educativo-adestradora dos modelos tradicionais científico, assistencial e pedagógico, em direção à compreensão profunda da gênese dos fenômenos com que estamos tratando. No caso específico da práxis educativa em saúde e alimentação, impõe, sobretudo, resgatar o sujeito neutralizado pelo crivo positivista do modelo da biomedicina. Esse modelo permite a dualidade alimentação-nutrição, por seu caráter disjuntivo e redutor. Modelo que reproduz nas práticas educativas em saúde, as marcas da educação que recebemos do sistema educativo mais amplo, neutralizando, não somente o humano na saúde, mas a humanidade do cuidador.

Torna-se crucial, consoante Bosi e Teixeira (2016, p. 904), incorporar a dimensão do vínculo, "o aprofundamento de vertentes educativas que operem no 'educar sensibilidades', usando a arte como recurso e 
articulando projetos interdisciplinares congruentes com a natureza do problema”. E indagam as autoras:

Quantas vezes esse aspecto é esquecido na Educação Alimentar Nutricional, sobretudo quando orientada pela pedagogia da transmissão? Modelo este que se funda na negação do diálogo, uma vez que o saber é monopólio de quem ensina; saber este repassado de forma mecânica, sem interação com os contextos, com objetivo de 'empilhamento', portanto, sem potencial emancipatório e de reconfiguração de comportamentos. (BOSI; TEIXEIRA, p. 904)

Aqui, é necessário considerar também as imensas distâncias e barreiras que se interpõem ao diálogo entre profissionais e usuários, por efeitos da distância social, preconceito e medo, diferenças de repertório e/ou lacunas na formação no que tange ao desenvolvimento de habilidades de comunicação, gerando adoecimento também nos cuidadores. As cartas fundadas numa produção artística seriam, portanto, uma via dupla de vocalização e de escuta.

Passando ao segundo âmbito demarcado como ilustração - a humanização em saúde -, cabe reconhecer que falamos muito em vínculo nos campos da saúde e Alimentação-Nutrição e essa categoria é naturalizada, depurada de sua complexidade. Conforme asseveram Barbosa e Bosi (2017), a despeito de se configurar como tema importante no âmbito do discurso do sistema de saúde brasileiro e o uso da palavra "vínculo" "adquirir uma linguagem especial na atenção básica" se trata de um "conceito problemático", uma vez que, a despeito da sua:

inequívoca importância no campo da saúde, o vínculo quase sempre é algo não demarcado, mas que [ainda assim] deveria existir como condição para funcionamento da atenção básica em termos de responsabilização e longitudinalidade do cuidado. (BARBOSA; BOSI, 2017, p. 1016)

Desse modo, se reconhece a crucialidade do encontro genuíno, mas ainda há pouco investimento na construção de espaços de sua efetivação. Hycner e Jacob (1997) apontam como fator primordial de cura, aqui tomada em sentido amplo, o que eles chamam de confirmar o outro. 
Confirmar significa um esforço consciente de olhar o outro como um ser único, singular, como alteridade, respeitando-o e aceitando-o na sua capacidade de fazer escolhas e de se responsabilizar por elas. Não seria esse o vínculo necessário? Como proporcionar esse encontro? Sem nos darmos conta da centralidade do diálogo, não construiremos um modelo centrado na humanização.

Acreditamos que a conversa na cidade, como dispositivo de encontro orientado por intervenções urbanas, como a que ilustra este capítulo, poderia alicerçar esse vínculo e recompor a escuta que, muitas vezes, somos incapazes de exercitar nas linhas de cuidado, quer pela sobrecarga imposta pela produção do cuidado em sua acepção técnica, quer pela exclusão dessa dimensão das rotinas dos serviços. Ou mesmo pela exclusão da subjetividade e dos sujeitos na planificação em saúde. Ou ainda pela disciplinarização presente nos processos de formação que isola os saberes no interior das instituições formadoras. Essa disciplinarização se aprofunda sob a égide de processos de avaliação acadêmica quando instauram, em contextos como o brasileiro, disputas entre campos - no sentido atribuído por Bourdieu. Essa "economia" conspira contra a interdisciplinaridade e a transculturalidade necessárias ao enfrentamento dos desafios - extraordinariamente complexos - que ora se apresentam na saúde e em todos os âmbitos em que incidem políticas sociais. Sendo assim, reifica-se o divórcio moderno entre arte-ciência (LUZ, 1988) que aqui pretendemos problematizar.

Essa ação comunicativa poderia, com vistas ao alcance dos seus propósitos, aproximar academia e serviços, e o circuito cultural que, grosso modo, pouco conversam. É curioso observar como educação, ciência e cultura são fracionadas em distintos órgãos ou agências estatais, com políticas quase sempre dissociadas, como se as três instâncias nada tivessem em comum. Também aqui precisamos construir pontes onde, atualmente, prevalecem muros. (BOSI; GASTALDO, 2011)

Mais do que isso: intervenções artísticas poderiam inovar no sentido da humanização em saúde, ao restituir a subjetividade às práticas e possibilitar um resgate da dimensão estética fundamental a ações promotoras 
ou de assistência à saúde, reforçando a qualidade do cuidado, ainda negligenciada na planificação de intervenções no setor. Falar em humanização e perseguir a incorporação deste princípio na produção do cuidado implica abrir a escuta, incluir os diferentes segmentos, em especial os mais vulneráveis, ou seja, envolve a inclusão de suas demandas subjetivas, valores, sentimentos e desejos, reconhecendo os conflitos inerentes aos vários processos de subjetivação em jogo, sem o que estaremos tratando com outras concepções de humanização distantes da que orienta esta discussão.

Neste ponto, evitando o uso leviano do conceito de "humanização", vale recuperar o que Uchimura e Bosi (2004, p. 99-100) sinalizam, ao sublinharem a necessária demarcação:

Humano se refere [...] ao plano das relações intersubjetivas que se processam nas práticas sociais, aqui referidas ao campo da saúde e, mais especificamente, ao plano dos programas no setor, tendo como seu fundamento a capacidade de simbolização e construção de sentidos em relação. Por relação intersubjetiva, espaço de humanização das práticas, não se está concebendo o contato entre indivíduos ou subjetividades isoladas [...] mas como relação simbólica entre sujeitos historicamente situados [...]. Isto equivale a dizer que humanizar significa possibilitar esse (re)encontro, esse contato genuíno que representa não a captura do que se é, mas a revelação do que é preciso expressar. Humanização implica, assim, em acolhimento e, sobretudo, em empatia e diálogo.

Nesse sentido, a arte representa um recurso poderoso, ainda pouco incorporado no cotidiano da práxis em saúde, a despeito da existência de uma Política Nacional de Humanização, e de um discurso vigoroso em torno desse princípio que permanece, a nosso ver, como utopia, haja vista o que denuncia a literatura voltada à avaliação da qualidade do cuidado, âmbito para o qual nossa discussão deslizará a partir de agora, como última ilustração selecionada.

Acreditamos ser possível inserir recursos artísticos, como a intervenção em tela, como componente na avaliação qualitativa de serviços, ainda carente de instrumentos capazes de recuperar a diversidade de discursos e representações sobre saúde de forma mais genuína, espontânea e evocativa. 
Guba e Lincoln (2011) dividem historicamente os modelos avaliativos em gerações e apontam importantes distinções que foram se apresentando com o passar do tempo, tornando os processos avaliativos mais efetivos e fundamentados, desdobrando-se em um construto que esses autores denominam "avaliação de quarta geração", uma tentativa de ruptura epistemológica e ético-política com os modelos anteriores.

Para os autores, a avaliação de quarta geração é uma construção social em que são levados em conta os contextos, a negociação, o envolvimento dos participantes interessados - que eles nomeiam stakeholders -, dentre vários outros aspectos, devendo-se utilizar métodos predominantemente qualitativos, ainda que se admita como necessária a complementaridade metodológica, haja vista a multidimensionalidade da qualidade em saúde. (UCHIMURA; BOSI, 2004)

Consoante Furtado (2001, p. 167), referindo-se à construção de Guba e Lincoln, "essa divisão em gerações de avaliadores é essencialmente didática e na realidade os diversos referenciais de avaliação coexistem, calcados em diversos eixos metodológicos". Contudo, cabe admitir que, dentre os méritos do modelo de quarta geração, se encontra o deslizamento da atitude punitiva e pouco participativa para um enfoque de fortalecimento e participação de todos os segmentos, em que o avaliador não é juiz, mas mediador, diferentemente das gerações anteriores. Não obstante tais avanços, sabemos ser ainda necessário, no contexto de países como o Brasil, não somente construir modelos, mas uma cultura da avaliação. Novamente, impõe-se diálogo, vínculo, projetos compartilhados.

Para tanto, os modelos emergentes (BOSI; MERCADO, 2010) orientados pelo enfoque qualitativo-participativo devem incluir novos e mais amplos recursos expressivos. Também aqui cabe refletir sobre as condições de possibilidade de construção de processos dialógicos e participativos, termos seguidamente empregados na literatura e nos espaços acadêmicos, e no nosso entendimento, ainda timidamente incorporados, no plano das práticas e da sua avaliação. Não seriam intervenções urbanas usando recursos artísticos um meio de a população - sobretudo em países onde ainda preocupam as taxas de analfabetismo - vocalizar suas 
demandas? O paradigma da arte-performance já se dissemina na pesquisa qualitativas, mas e nas práticas avaliativas? Como poderiam subsidiar?

No que concerne à avaliação das práticas em saúde que se desenvolvem na diversidade das cidades, a despeito da emergência de enfoques diversos e do acúmulo já verificado, acreditamos que temos, ainda, uma grande tarefa pela frente, que nos exige inventividade, ousadia, correr riscos e desenhar proposições em planos distintos, cientes do desafio de inovar nos planos do saber; da formação; da construção de programas e de novas formas de organização e avaliação dos serviços.

Uma proposta que se afirme em consonância com a efetiva transformação, não pode se isentar de um posicionamento que se contraponha aos modelos hierárquicos e autoritários, pois o contrário apenas os reforçaria. A arte pode sustentar processos mais democráticos. Porquanto, não há diálogo sem democracia. Não há vínculo fortalecedor sem novas disposições de poder. A participação social que reforça a democracia nos processos avaliativos - e outros - carece ter lugar assegurado. Tal assertiva interpela muitos dos instrumentos ou tecnologias empregados na avaliação tradicional à medida que restringem ou impedem a escuta e o diálogo. (BOSI; UCHIMURA, 2010)

Nesse sentido, práticas e instrumentos que incrementam a participação de todos os grupos de interesse nos diferentes níveis do sistema de saúde devem ser efetivados e deveriam ser igualmente objetos incluídos nos processos de construção de modelos avaliativos, sob a égide da imprescindível reflexividade (BOOT, 2010), dados o caráter hermenêutico e a dimensão axiológica das avaliações.

Portanto, produzir formas de interação incrementando a participação popular e o diálogo população-serviços deve ser um objetivo a ser contemplado em propostas avaliativas que se pretendam efetivamente qualitativas e participativas. Aqui, importam, mais uma vez, os efeitos políticos do discurso, haja vista que o linguajar técnico tantas vezes inacessível, seguidamente referido no discurso popular, impede a população de se expressar, pelo efeito de poder do "discurso competente" (CHAUÍ, 2011), que se capilariza na micropolítica das linhas de cuidado 
e se instaura em instâncias "participativas" supostamente democráticas - conselhos, comissões, fóruns -, mas que provocam silêncio ou falsos consensos, na tentativa infrutífera, dados os dilemas de representação, de abrir uma conversa na cidade. Problemas que desafiam todas as gerações de avaliação, mesmo as mais avançadas.

Assim, também no campo da avaliação de programas, temos uma grande tarefa pela frente que inclui desafios que incluem inter-poli-transculturalizar. (MORIN, 2004) Não basta questionar o modelo tradicional. É preciso operacionalizar nos diferentes contextos urbanos uma nova postura ética para com o outro, na qual a arte é uma poderosa aliada. Portanto, uma concepção complexa voltada à construção de alternativas direcionadas à promoção da saúde precisa considerar a ousadia e o risco como peças nesse exercício, rompendo com o já dito ou o superando em direção a novas sínteses, muitas vezes sequer pensadas no início do percurso, mas que podem, de forma surpreendente, responder aos imensos desafios que hoje se colocam no campo da alimentação e da saúde.

\section{PARA CONCLUIR}

Recuperando em breves linhas o que pretendemos problematizar e defender neste capítulo, acreditamos que intervenções urbanas são possíveis agentes de humanização da cidade e das práticas que nela se desenvolvem, incluindo aquelas voltadas à promoção da saúde e da alimentação adequada, campos para os quais se volta nosso olhar. As cidades, mais precisamente, as diversas e complexas experiências urbanas atuam como determinante social em saúde e, no que concerne à humanização do cuidado, a arte pode acionar novas formas de conexão entre a população e os serviços de saúde, ampliando o alcance das ações.

Nesse escopo, diferentes formas de expressão estética podem ser apropriadas ou inspirar não somente ações educativas em alimentação e nutrição, mas vias de construção de acolhimento e diálogo entre os atores, dentre eles, profissionais e usuários. Desafia-nos, sobretudo, a inserção de segmentos, grosso modo, pouco contemplados ou mesmo 
excluídos nos espaços institucionalizados e dispositivos integrantes da rede de atenção cujas necessidades são ainda pouco conhecidas e consideradas na planificação de ações na rede de atenção.

Como ilustração do que propomos, tomamos aqui para análise um, dentre vários projetos de intervenção urbano-poética, realizado na cidade de Fortaleza, Ceará. O projeto "pra você" ganhou repercussões expressivas, virando pauta de matérias em diversos jornais locais e nacionais, em que se reiterava o desejo de encontrar uma das mensagens, distribuídas sob forma de cartas afixadas em diversos locais da cidade.

Observar esse projeto e a surpreendente reação por ele gerada, ainda que inscrito e direcionado em âmbito distinto do que se considera "área da saúde", nos inspirou a pensar sobre as potencialidades de intervenções artísticas no espaço urbano, para práticas voltadas à qualidade da saúde, sobretudo aquelas que implicam dimensões simbólicas, subjetivas, como no caso da alimentação. Intervenções como "pra você", com o apoio da mídia, redes sociais e da gestão pública, poderiam ser apropriadas, superando os formatos tradicionais das ações, em especial as educativas, grosso modo, restritas ao repasse de informações sem ressonância na dimensão afetiva da população, enferma ou sadia. Mais do que isso, poderiam inovar no sentido da humanização em saúde, ao restituir a subjetividade às práticas e possibilitar o resgate da dimensão estética fundamental a ações promotoras ou de assistência à saúde, reforçando a qualidade do cuidado, ainda negligenciada na planificação de intervenções no setor.

Por fim, acreditamos ser possível inseri-las como componente na avaliação qualitativa de serviços, ainda carente de instrumentos capazes de recuperar distintos discursos de forma mais genuína, espontânea e evocativa.

\section{REFERÊNCIAS}

ARAÚJO, R. A cidade sou eu? O urbanismo do século XXI. 2007. Tese

(Doutorado em Urbanismo) - Faculdade de Arquitetura e Urbanismo, Universidade Federal do Rio de Janeiro, Rio de Janeiro, 2007. 
AUGÉ, M. Não lugares: introdução a uma antropologia da sobremodernidade. Lisboa: 90 graus, 2005.

AZEVEDO, M. T. O. Passeio de sombrinhas: poéticas urbanas, subjetividades contemporâneas e modos de estar na cidade. Revista Magistro, Duque de Caxias, v. 8, n. 2, p. 138-146, 2013.

BARBOSA, M. I. S.; BOSI, M. L. M. Vínculo: um conceito problemático no campo da Saúde Coletiva. Physis: Revista de Saúde Coletiva, Rio de Janeiro, v. 27, n. 4, p. 1003-1022, 2017.

BOOT, E. Favorites and others: reflexivity and the shaping of subjectivities and data in qualitative research. Qualitative research, Thousand Oaks, v. 10, n. 2, p. 159-173, 2010.

BOSI, M. L. M.; GASTALDO, D. Construindo pontes entre ciência, política e práticas em saúde coletiva. Revista de Saúde Pública, São Paulo, v. 45, n. 6, p. 1197-1200, dez. 2011.

BOSI, M. L. M; MERCADO, F. J. Avaliação qualitativa de programas e serviços: enfoques emergentes. Petrópolis: Vozes, 2010.

BOSI, M. L. M.; TEIXEIRA, M. J. Compulsão alimentar sob um olhar complexo: subsídios para a práxis da educação alimentar e nutricional. Revista de Nutrição, Campinas, v. 29, n. 6, p. 899-915, 2016.

BOSI, M. L. M; UCHIMURA, K. Y. Avaliação qualitativa de programas em saúde: contribuições para propostas metodológicas centradas na integralidade e na humanização. In: BOSI, M. L. M.; MERCADO, F. J. (org.). Avaliação qualitativa de programas em saúde: enfoques emergentes. Petrópolis: Vozes, 2010. p. 87-117.

CHAUÍ, M. S. Cultura e democracia: o discurso competente e outras falas. São Paulo: Cortez, 2011.

FURTADO, J. P. Um método construtivista para a avaliação em saúde. Ciência \& Saúde Coletiva, Rio de Janeiro, v. 6, n. 1, p. 165-181, 2001.

GUBA, E. G.; LINCOLN, Y. S. Avaliação de quarta geração. Tradução de Beth Honorato. Campinas: Editora da UNICAMP, 2011.

HARVEY, D. Cidades rebeldes: do direito à cidade à revolução urbana. São Paulo: Martins Fontes, 2014.

HYCNER, R.; JACOB, L. Relação e cura em gestalt-terapia. São Paulo: Summus, 1997. 
HYPOLITO, B.; ROCHA, E. A cidade e as escritas urbanas. In: ENCONTRO DE PÓS-GRADUAÇÃO, 15., 2013, Pelotas. Anais [...]. Pelotas, 2013. p. [1-4]. Disponível em: http://cti.ufpel.edu.br/siepe/arquivos/2013/SA_01323.pdf. Acesso em: 5 fev. 2017.

LEFEBVRE, H. O direito à cidade. 5. ed. São Paulo: Centauro, 2008.

LE MOIGNE, J.-L. A inteligência da complexidade. In: PENA-VEJA, A.; NASCIMENTO, E. P. (org.). O pensar complexo: Edgar Morin e a crise da modernidade. Rio de Janeiro: Garamond, 1999.

LUZ, M. T. Natural, racional, social: razão médica e racionalidade científica moderna. Rio de Janeiro: Campus, 1988.

MERLEAU-PONTY, M. Fenomenologia da percepção. São Paulo: Martins Fontes, 1999.

MORIN, E. A cabeça bem-feita: repensar a reforma, reformar o pensamento. 9. ed. Rio de Janeiro: Bertrand do Brasil, 2004.

MORIN, E. Introdução ao pensamento complexo. Porto Alegre: Sulina, 2006.

SÁ, T. Lugares e não lugares em Marc Augé. Revista Tempo Social: revista de sociologia da USP, São Paulo, v. 26, n. 2, p. 209-229, nov. 2014.

SILVA, A. Imaginários Urbanos. São Paulo: Arango, 2006.

SOJA, E. W. Geografias pós-modernas: a reafirmação do espaço na teoria social. Tradução de Vera Ribeiro. 2. ed. Rio de Janeiro: Jorge Zahar, 1993.

STENZEL, L. M. Obesidade: o peso da exclusão. Porto Alegre: EDIPUCRS, 2002.

TAVARES, A. Ficções urbanas: estratégias para a ocupação das cidades. ARS, São Paulo, ano 7, n. 16, p. 21-30, 2010.

UCHIMURA, K. Y.; BOSI, M. L. M. A polissemia da qualidade na avaliação de programas e serviços de saúde: resgatando a subjetividade. In: BOSI, M. L. M.; MERCADO, F. J. (org.). Pesquisa qualitativa em serviços de saúde. Petrópolis: Vozes, 2004. p. 75-98.

VIEIRA, J. A. Teoria do conhecimento e arte: formas de conhecimento: arte e ciência uma visão a partir da complexidade. Fortaleza: Expressão Gráfica e Editora, 2008.

VIRILIO, P. Paul Virilio: entrevista concedida a Laymert Garcia dos Santos. In: BEIRÃO, N. America: depoimentos. Tradução de Suyan Marcondes de Souza Brown. São Paulo: Companhia das Letras; Rio de Janeiro: Videofilmes, 1989. p. 133-140. 


\section{Feminismos e agroecologia lutas contemporâneas na cidade}

MARIA DA GRAÇA COSTA, MAGDA DIMENSTEIN E JÁDER FERREIRA LEITE

\section{INTRODUÇÃO}

Pela primeira vez na história, mais da metade da população mundial vive nas cidades. De acordo com o relatório Perspectivas da Urbanização Mundial (World Urbanization Prospects), produzido pela Divisão das Nações Unidas para a População do Departamento de Assuntos Econômicos e Sociais, $54 \%$ da população mundial vive em áreas urbanas, com perspectiva de aumento para 66\% em 2050. O relatório

1 Este texto é parte da tese de doutorado Mulheres e agroecologia no Rio de Janeiro: construindo uma política feminista a partir das margens defendida no Programa de Pós-Graduação em Psicologia da Universidade Federal do Rio Grande do Norte (UFRN). A pesquisa contou com apoio financeiro da Coordenação de Aperfeiçoamento de Pessoal de Nível Superior (Capes), por meio da concessão de bolsa de pesquisa. 
também destaca a previsão de que, em 2030, 80\% da população urbana estará concentrada em cidades de países em desenvolvimento, configurando um processo de urbanização intimamente ligado ao crescimento da pobreza e da insegurança alimentar. (DESA, 2014)

Em pesquisa sobre disponibilidade de alimentos na cidade de São Paulo, Ana Clara Duran (2013) constatou uma significativa diferença no acesso a alimentos saudáveis por parte da população, com favorecimento das regiões da cidade de níveis socioeconômicos médio e alto. Resultado semelhante foi encontrado em estudos-como os de Costa e Cipolla (2016) na cidade do Rio de Janeiro, Leda (2017) em Brasília e o de Bento (2017) em Campinas. (BENTO, 2017) Essas pesquisas apontam que aspectos do ambiente alimentar, tais como distância, renda, exposição à publicidade, informação, dentre outros, estão associados diretamente ao consumo de frutas, hortaliças e bebidas açucaradas, mostrando que as comunidades das regiões mais pobres dos centros urbanos vêm se configurando como "desertos alimentares", conceito formulado para definir os lugares com difícil acesso a alimentos nutritivos. (MOK et al., 2014)

As desigualdades de produção, acesso e distribuição de alimentos saudáveis nas cidades, somadas à confluência das crises ambiental, econômico-política e social, suscitam questionamentos acerca das alternativas locais baseadas na agroecologia e na agricultura familiar e de seu papel frente à globalização do sistema agroalimentar capitalista. (PRADO, 2015) A agroecologia é um campo de saberes e práticas integrados que se constitui tanto como tecnologia quanto como movimento social. Representa um paradigma de produção agrícola, que visa reduzir o impacto socioambiental da produção de alimentos, ao valorizar os conhecimentos tradicionais e o campesinato enquanto sujeito e forma de organização social. (MARCOS, 2007) A agroecologia vem sendo tomada por muitos atores e movimentos sociais como um grande projeto de transformação social, tanto nas cidades caracterizadas como "rurais" e de pequeno porte quanto nos grandes centros urbanos brasileiros, articulando pautas diversas, tais como soberania alimentar, ${ }^{2}$ luta pela moradia e, notadamente, os feminismos.

2 Esse conceito refere-se à soberania para decidir o que se cultiva e se come, o que não é pos- 
Vários estudos - como os de Jalil (2009) e Siliprandi (2015) mostram que a inserção das mulheres no modo de produção agroecológico pode ter grande impacto na redução das desigualdades de gênero na esfera da agricultura, com a valorização do trabalho considerado feminino - a agricultura de subsistência, o trabalho do cuidado, trabalho doméstico -, o qual é historicamente invisibilizado; a maior participação política das mulheres em movimentos sociais organizados; e uma organização produtiva compartilhada entre homens e mulheres de maneira mais equânime.

É inegável a relevância da atuação das mulheres na agroecologia. Tal protagonismo aponta não só para o reconhecimento da importância dos saberes das mulheres na construção de sistemas de produção agroalimentares e de economia alternativos, como traz à tona o debate sobre as interseccionalidades entre gênero, raça, classe e sexualidade e a forma como as desigualdades se relacionam ao modelo de desenvolvimento capitalista e às formas de exploração do meio ambiente. Ademais, abre uma fenda de intensos enfrentamentos sobre a configuração atual das cidades e sobre as experiências de habitar e vivenciar o urbano, cenário cotidiano de vivências e intensas lutas e disputas. Pauta-se, com isso, um fazer político, a partir da politização do cotidiano, da criação de alternativas ao desenvolvimento e da centralidade da ideia de considerar a alimentação e o corpo como territórios - por excelência - de resistência feminista.

Este trabalho situa-se no bojo desse emaranhado, que relaciona temas como feminismo, gênero, movimentos sociais, agroecologia, alimentação e cidade. Partimos de algumas indagações disparadoras, a saber: quais estratégias de luta e mobilização política são articuladas a partir desses movimentos e do protagonismo das mulheres? Que vivências, afetos e novas posicionalidades no cotidiano são experimentadas pelas mulheres mediadas pela participação nos movimentos feministas e agroecológico? Que narrativas são produzidas por essas protagonistas em relação ao direito à cidade? $\mathrm{O}$ presente texto tem como objetivo

sível em maior parte das nações devido às atuais políticas agrícolas e alimentares globais. 
discutir tais questões e analisar em que medida a articulação entre os movimentos agroecológico e feminista(s) constitui um vetor de subjetivação estruturador de novos modos de sentir e viver, com potencial de romper com as ideologias hegemônicas de gênero, de construir redes de atuação política, de produzir novas experiências urbanas e práticas, no âmbito da cidade.

Para tanto, iremos nos ancorar nos resultados de uma cartografia realizada com o intuito de conhecer mais detalhadamente o funcionamento do dispositivo "roda de mulheres", o qual está integrado à Rede Carioca de Agricultura Urbana (Rede CAU). Essa rede é constituída por mulheres organizadas em grupos populares, institutos de pesquisa, organizações não governamentais, agricultoras urbanas, moradoras de periferias e favelas do Rio de Janeiro. Elas vêm tecendo redes autônomas e feministas de produção, comercialização e comunicação agroecológica na cidade.

Utilizamos o referencial teórico-metodológico da cartografia, a partir de Deleuze e Guattari (1995) e Rolnik (2001), entendida como um mapa às avessas, que nos ajuda a nos perdermos nos emaranhados da cidade, buscando acompanhar os diversos processos que se desenrolam no contexto estudado e a produção de subjetividades concomitante a esses contextos. A escolha da cartografia parte de uma concepção que rompe com o paradigma representacional da ciência e da neutralidade na produção de conhecimento, buscando potencializar a singularidade que envolve o fazer pesquisa e o lugar do(a) pesquisador(a) nesse processo, a partir da construção de um "plano-comum" de afetos e constituição mútua entre todos agentes envolvidos no processo de investigação, de forma que a divisão entre pesquisadores(as) e "objetos de pesquisa” perde o sentido. Mais do que um procedimento metodológico delimitado, tomamos a cartografia como um modo de conceber a pesquisa e o encontro de nós, pesquisadores(as), com nosso campo, que é sempre uma intervenção.

A partir desse olhar, desde o ano de 2015, a roda de mulheres da Rede CAU vem sendo acompanhada, com nossa participação na construção de mutirões agroecológicos, feiras, eventos e encontros de agroecologia 
e dos movimentos feministas. Partiremos, neste trabalho, das reflexões formuladas a partir desses encontros e da própria vivência da primeira autora enquanto militante dos movimentos agroecológico e feministas e habitante do território Rio de Janeiro.

\section{NOVAS URBANIDADES: AGROECOLOGIA E DIREITO À CIDADE}

As cidades são invenção humana por excelência. Nelas, a humanidade refaz o mundo em que vive, a partir dos seus desejos, e é nelas que essa humanidade está condenada a viver. (PARK, 1973) Como argumentam Romero e Zamora (2016), é impossível pensar a subjetividade humana contemporânea separada da experiência urbana. Com suas infinitas possibilidades e acontecimentos, as cidades são espaços privilegiados para as múltiplas possibilidades do "ser" e "estar no mundo", são megamáquinas produtoras de subjetividade individual e coletiva, que "engendram, por meio de equipamentos materiais e imateriais, a existência humana sob todos os aspectos". (GUATTARI, 1992, p. 152)

Guattari (1992) apresenta os aspectos de produção de subjetividade pelas cidades a partir do paradoxo da desterritorialização - com a globalização e grande circulação de pessoas, discursos publicitários, tecnologias - e homogeneização dos modos de ser e existir. Em um mesmo sentido, vários autores de diferentes áreas, como Arquitetura, Urbanismo, Psicologia e Antropologia, vêm discutindo o modo hegemônico que opera a administração do corpo da cidade, a partir da ideia de "espetacularização urbana" como uma construção da experiência urbana, que é pautada por princípios segregadores e despolitizadores, que lhe conferem um sentido mercadológico, turístico e consumista. (BRITTO; JACQUES, 2009)

A espetacularização urbana pode ser entendida como o processo de construção da cidade por meio de uma arquitetura espetacular e um urbanismo integrado aos padrões éticos e estéticos da mundialização. (TEOBALDO, 2010) Esse processo tem como efeito o empobrecimento da experiência urbana dos seus habitantes e, à medida que os espaços 
públicos vão sendo esvaziados, a cidade aos poucos deixa de ser o espaço da diversidade, com um progressivo abandono do social e da urbanidade ou, como aponta Eliana Kuster (2014, p. 54), “uma decadência do sentido de cidade". Para Britto e Jacques (2009), esse modo de subjetivação manifesta-se na formulação dos discursos e comportamentos que permeiam e, até mesmo, fundamentam desde os planejamentos e ações da administração pública das cidades até as próprias relações mais íntimas de seus habitantes.

Nos regimes de subjetivação urbana do neoliberalismo, a vida coletiva das cidades é sobrepujada pelo domínio do privado. Crescem as práticas de segregação social em nome do desenvolvimento urbano, valendo-se de técnicas sofisticadas de vigilância, policiamento e arquitetura, que incluem a criminalização da pobreza e o cerceamento dos espaços públicos. (AMADOR; FERNANDES, 2016) Questionamo-nos, dessa forma, sobre as possibilidades de construção de subjetividades singulares e singularizantes que escapem às modelizações dominantes na cidade.

Ao mesmo tempo em que são alvos de regimes de subjetivação ancorados em dispositivos capitalistas, as cidades e seus habitantes são atravessados por conflitos, heterogeneidades e resistências. Na medida em que os regimes de subjetivação hegemônicos se alargam, surgem, cada vez mais, estratégias de resistência que articulam direito, cidade e bem- estar como diferentes expressões de uma ética que tem como ponto de partida a experiência da diferença. (SILVA, 2013) Esses processos de resistência têm sido comumente abarcados a partir da ideia de direito à cidade. Esse conceito, amplamente utilizado por movimentos sociais e agentes governamentais, é um termo em disputa no que se refere à abrangência dos seus significados e pautas de reivindicação que contempla.

O conceito de direito à cidade surge, com o filósofo e sociólogo marxista francês Henri Lefebvre (2001), como uma crítica ao urbanismo positivista e ao processo de alienação dos cidadãos das questões urbanas, encaradas exclusivamente a partir dos vieses administrativo, técnico e científico, que são fruto de relações econômicas de dominação 
e de políticas urbanísticas, por meio das quais o Estado ordena e controla os indivíduos, que são vistos enquanto objetos, e não como sujeitos do espaço social. Para além do debate acadêmico, em todo o mundo, o direito à cidade tem sido utilizado para reivindicar questões tais como o direito à moradia, saneamento básico e mobilidade, além de ser utilizado como forma de defesa às diversas possibilidades de ocupação das cidades.

No Brasil, o movimento pelo direito à cidade ganha força por meio do Movimento Nacional de Reforma Urbana (MNRU), que em sua articulação consegue, junto a outros movimentos e atores políticos, garantir a inclusão do capítulo sobre política urbana na Constituição de 1988. Porém, a regulamentação do direito humano à cidade só acontece a partir da implementação, em 2001, do Estatuto das Cidades, que institui a política urbana brasileira e efetiva no ordenamento jurídico, o direito a cidades sustentáveis, entendido "como o direito à terra urbana, à moradia, ao saneamento ambiental, à infraestrutura urbana, ao transporte e aos serviços públicos, ao trabalho e ao lazer, para as presentes e futuras gerações [...]". (BRASIL, 2001)

A despeito do reconhecimento formal de tais direitos, as cidades brasileiras seguem sendo cenários de perpetuação de desigualdades econômicas e sociais, "sendo sua população, em sua maioria, privada ou limitada - em virtude de suas características econômicas, sociais, culturais, étnicas, de gênero e idade - de satisfazer suas necessidades básicas". (FMS, 2006, p. 1) Como consequência, os novos atores que se agregaram às lutas urbanas no período recente, para além de defender a implementação do Estatuto da Cidade, passaram a difundir o direito à cidade como forma de unificar pautas que possuem formas de expressão fragmentadas. Essa nova narrativa tem sido bem recebida e potencializada nos espaços de articulação política, com destaque para aqueles que reúnem acadêmicos, organizações não governamentais e movimentos sociais.

É importante ressaltar que o direito à cidade não pode ser resumido aos objetivos e direitos individuais de ordem prática, tais como moradia e transporte, mas precisa considerar a dimensão do comum, de abertura 
ao outro, de acolhimento à multiplicidade e que produz um funcionamento difícil de capturar. Para Harvey (2012, p. 74):

$\mathrm{O}$ direito à cidade está muito longe da liberdade individual de acesso a recursos urbanos: é o direito de mudar a nós mesmos pela mudança da cidade. Além disso, é um direito comum antes de individual já que esta transformação depende inevitavelmente do exercício de um poder coletivo de moldar o processo de urbanização. A liberdade de construir e reconstruir a cidade e a nós mesmos é, como procuro argumentar, um dos mais preciosos e negligenciados direitos humanos.

Nesse sentido, esse conceito nos instiga a pensar sobre quais resistências podem ser construídas a partir de estratégias que potencializem diferentes possibilidades de ocupar, experienciar e pensar a cidade não só como práticas individuais, mas principalmente enquanto um projeto amplo de ressignificação das relações construídas no e com o espaço urbano, enquanto "cidades-devires-revolucionários". (AMADOR; FERNANDES, 2016, p. 253)

Compartilhando dessas inquietações, diversos atores vêm construindo pontes entre o movimento de Agricultura Urbana (AU) e o direito à cidade, entendendo que ambos compartilham de pautas ou convergem no sentido da tessitura de cidades sustentáveis. O direito à cidade aparece no título da carta política do I Encontro Nacional de Agricultura Urbana (Enau), ${ }^{3}$ realizado, em 2015, na cidade do Rio de Janeiro; nos documentos oficiais da $5^{a}$ Conferência Nacional de Segurança Alimentar e Nutricional, intitulada de "Comida de verdade no campo e na cidade" e como uma das frentes de trabalho da Articulação Nacional de Agroecologia (ANA), principal espaço de articulação entre redes e organizações voltadas para a promoção da agroecologia no país.

A associação quase instantânea que é feita entre agricultura e meio rural pode levar a uma impressão de incompatibilidade entre eles. Entretanto, a AU não é uma atividade recente e sempre se expressou nas

3 "Agricultura urbana e direito à cidade: cultivando saúde e comida de verdade". 
grandes cidades, mesmo que muitas vezes restrita a pequenos quintais produtivos, hortas em escolas, em associações de moradores etc.

A AU inclui a produção, a transformação e a prestação de serviços para gerar produtos agrícolas e pecuários voltados ao autoconsumo, trocas e doações ou comercialização, (re)aproveitando, de forma eficiente e sustentável, os recursos e insumos locais - solo, água, resíduos, mão de obra, técnicas etc. -, estando vinculada às dinâmicas urbanas ou das regiões metropolitanas e articulada com a gestão territorial e ambiental das cidades. É importante destacar que: a) não é a localização urbana que distingue a $\mathrm{AU}$ da agricultura realizada em áreas convencionalmente designadas enquanto rurais, senão o fato de que está integrada e interage com o ecossistema urbano; b) as experiências são muito diversas, sendo praticadas em quintais, hortas coletivas em espaços públicos, produções em grande escala em áreas metropolitanas e, enquanto a maior parte das experiências se baseia no sistema de produção orgânico, outras podem fazer uso de insumos químicos e agrotóxicos.

Para Aquino e Assis (2007), o sistema de produção orgânico de base agroecológica é considerado especialmente apropriado para o contexto urbano, posto que:

a) a baixa dependência de insumos externos facilita a adoção de agricultura em pequena escala;

b) possibilita aumento de renda para as famílias produtoras, ao agregar valor aos produtos e ampliar o mercado, facilitando a comercialização;

c) promove a segurança alimentar e a saúde das pessoas envolvidas, por possibilitar a produção e o consumo de alimentos sem agrotóxicos;

d) tem a capacidade de manter e/ou recuperar a biodiversidade dos agroecossistemas do entorno.

Para além dos aspectos acima citados, ressaltamos, ainda, a forma com que a articulação da $\mathrm{AU}$ a partir da agroecologia contribui para 
formação de redes e o fortalecimento comunitário, na medida em que integra diversas bandeiras e estratégias de atuação, politizando, sobremaneira, a prática da agricultura e tudo o que a envolve: produção, consumo, alimentação, cultura, tradição etc. Assim, não apenas a perspectiva econômica e produtiva, mas a noção de multifuncionalidade da agricultura (FERNANDEZ, 2014) deve ser adotada para a compreensão da relevância da agricultura de base agroecológica nas áreas urbanas, considerando seus impactos nas dimensões de reconhecimento, de subsistência, bem-estar, conservação da natureza, sociabilidade e valorização dos sujeitos envolvidos.

Apesar da importância e abrangência da AU, Prado (2015) aponta que ela ainda tem sido pouco valorizada, ou até desconsiderada, pelo poder público, especialmente no que se refere ao reconhecimento das iniciativas de AU como uma forma de agricultura familiar. Isso pode ser expresso pela ausência de uma lei ou marco regulatório da $\mathrm{AU}^{4}$ e pela dificuldade de obtenção da Declaração de Aptidão ao Pronaf ${ }^{5}$ (DAP), o que inviabiliza a inclusão dos produtores em programas de fortalecimento da agricultura familiar, como o Programa de Aquisição de Alimentos (PAA) e o Programa Nacional de Alimentação Escolar (PNAE).

Diante dessa invisibilidade, o conceito de AU de base agroecológica ganha força, fazendo com que vários(as) produtores(as) se nomeiem como "agricultores(as) urbanos(as)" e se organizem em redes de produção, comercialização e beneficiamento, além de reivindicarem o reconhecimento de suas práticas por meio de políticas, subsídios e uma legislação específica de fomento.

A AU e as múltiplas questões envolvidas em sua prática abrem espaço para uma discussão sobre os modos de vida promovidos pelo espaço urbano em sua relação com o rural, relação essa que, por muito tempo, foi compreendida a partir da ideia de uma oposição mútua. Prado (2015)

4 Atualmente, um Projeto de Lei (PL), o PL n 906/2015, que busca regular a AU no país, está em tramitação na Câmara dos Deputados.

5 Programa Nacional de Fortalecimento da Agricultura Familiar. 
traz um debate interessante sobre tal relação, a partir de um conjunto de fenômenos que refutam as profecias alardeadas pelos teóricos do desenvolvimento rural e da Sociologia Rural clássica, que previam o inexorável desaparecimento das comunidades e dos modos de vida "rurais":

O processo de modernização da agricultura não só não confirmou tais previsões, como hoje se veem reafirmados - não sem obstáculos, é importante constatar - os modos de vida do mundo rural e do campesinato em conexões inéditas com as cidades e regiões metropolitanas. Nestas que por muito tempo foram entendidas como ápice do projeto modernizante, do consumo acelerado e da desconexão com a natureza, assistimos à generalizada emergência de práticas que respondem contrariamente àquele projeto, seja na valorização dos meios alternativos de transporte, na retomada do uso dos espaços públicos ou nos movimentos sociais que reivindicam o direito a uma outra cidade. (PRADO, 2015, p. 6)

Se os espaços rurais já foram compreendidos como áreas cuja principal função era fornecer alimentos baratos e em grandes quantidades para os consumidores urbanos, as mudanças em curso nas dinâmicas sociais, econômicas e culturais do meio rural, a partir dos processos de modernização da produção agrícola e de crescente urbanização, ganham novos significados à luz de questões políticas emergentes ligadas aos temas da soberania e da segurança alimentar, da agroecologia e dos modos de produção da agricultura familiar, de forma que as categorias simbólicas "rural” e "urbano" e as representações sociais que as envolvem se desestabilizam, impossibilitando a definição de uma fronteira clara. (PRADO, 2015)

Entretanto, esse processo não resulta no desaparecimento e na descaracterização das culturas locais rurais a partir de uma homogeneização da cultura no sentido da urbanização, como se o campo e a cidade fossem "estágios respectivamente inicial e final de uma mudança qualitativa”. (SAHLINS, 1997, p. 113) Pelo contrário, concordamos com Sahlins (1997) quando o mesmo diz que a cultura é dinâmica e implica a reelaboração constante em todas as esferas do social. É nesse sentido que podemos pensar, para além do conceito de "novas ruralidades" largamente utilizado na Geografia e Sociologia Rural para designar a 
ampliação das possibilidades do rural para além da esfera da produção agrícola -, uma ideia de "novas urbanidades", para entender como as noções de "rural" e "campesinato" são acionadas e ressignificadas de forma a valorizar maneiras de habitar as cidades que consideram a sustentabilidade enquanto um direito humano à cidade.

Na esteira desse processo, assiste-se em todo o mundo à proliferação de experiências de AU em configurações e cenários diversos. Uma das mais conhecidas e exitosas iniciativas de $\mathrm{AU}$ no que se refere à promoção de segurança e soberania alimentar é a desenvolvida por Cuba desde os anos de 1990. A ilha possui uma política pública nacional de produção de alimentos orgânicos, de manejo de resíduos sólidos e compostagem através da formação de cooperativas de produção. Outra iniciativa reconhecida pela sua abrangência é a de Vancouver, no Canadá, onde, desde 2003, por meio de uma política municipal de apoio a um sistema alimentar "justo e sustentável" - o Plano de Ação Alimentar - e a formação do Conselho de Política Alimentar de Vancouver, observou-se o número de hortas comunitárias crescer. A cidade classificou a agricultura urbana como uma prioridade-chave para o desenvolvimento local, com impactos significativos na promoção da alimentação saudável, da educação ambiental, geração de renda e integração comunitária, especialmente em bairros com maior vulnerabilidade socioeconômica.

Movimentos autônomostambém chamamatenção, comoaJardinagem de Guerrilha (Guerrilla Garden), ${ }^{6}$ movimento social transnacional com experiências documentadas em mais de 30 países. As ações desse movimento incluem a ocupação de áreas ociosas nas cidades para o desenvolvimento de hortas coletivas com a produção voltada para o consumo dos moradores do entorno e estratégias de intervenção urbana por meio da arte para a conscientização ambiental em grandes cidades. Em geral, essas hortas são constituídas em bairros periféricos ou de áreas extremamente urbanizadas, com pouca área verde disponível. Com mais de 30 anos, esse movimento contabiliza importantes ganhos, com a desapropriação

6 Disponível em: http://www.guerrillagardening.org/. 
e construção de parques e áreas próprias para plantio reconhecidas pelo Estado em cidades como Berkeley e Nova Iorque, nos Estados Unidos.

No Brasil, metrópoles como São Paulo e Belo Horizonte possuem políticas municipais voltadas para a produção agrícola, ao mesmo tempo em que o número de experiências de produção autônoma e coletiva se multiplica em diversas cidades. No Rio de Janeiro, esse movimento vem ocorrendo, principalmente, em duas frentes: no reconhecimento da agricultura familiar tradicional realizada na cidade e no desenvolvimento de novas iniciativas com hortas comunitárias e em quintais familiares, que confluem no fortalecimento de uma rede de ativistas e agricultores(as) urbanos(as), como veremos a seguir.

\section{AGROECOLOGIA FEMINISTA E PERIFÉRICA: CONECTANDO LUTAS, RESSIGNIFICANDO PRÁTICAS NO COTIDIANO}

Construída em meio a cadeias de montanhas, floresta de mata atlântica e o mar, a "cidade maravilhosa" é um caso emblemático do fenômeno da espetacularização urbana no país. Com a constituição do Rio de Janeiro enquanto capital da colônia, a partir do século XVIII, a cidade vê sua população aumentar rapidamente e se amontoar em cortiços na sua região central. O plano urbanístico de Pereira Passos, executado no início do século XX e inspirado no projeto implementado em Paris por Le Corbusier, foi responsável pela transformação da cidade, em especial do Centro, com a derrubada do Morro do Castelo e a construção de grandes alamedas e avenidas que inviabilizaram, quase por completo, a possibilidade de o centro da cidade funcionar enquanto área residencial e de estabelecimento de pequenos comércios. A cidade é, então, alvo de processos de higienização social, sendo vendida como paraíso de investimento financeiro, industrial, turístico e imobiliário e uma das capitais culturais do país.

Desde o ano de 2007, o Rio de Janeiro vem passando por intensas transformações urbanas, em função do aumento da especulação imobiliária - a cidade tem, hoje, um dos maiores valores por metro quadrado 
do mundo - e do investimento em infraestrutura para a realização de megaeventos, tais como a Copa do Mundo de Futebol, em 2014, e os Jogos Olímpicos, em 2016, além de um intenso projeto de militarização, com a instituição das Unidades de Polícia Pacificadora (UPP) em favelas, dentre outras estratégias.

O Rio de Janeiro é a segunda maior cidade do país e conta, hoje, com aproximadamente 7 milhões de habitantes. (IBGE, 2017) Desde 2011, de acordo com o plano diretor municipal, não há áreas consideradas rurais na cidade do Rio de Janeiro. Entretanto, os dados do último Censo Agropecuário do IBGE (2006) evidenciam a relevância da agricultura na cidade: concentrando $53 \%$ da população da região metropolitana, o município do Rio de Janeiro apresentava 1.055 estabelecimentos agrícolas, sendo 790 de agricultura familiar. Grande parte dos núcleos de agricultura familiar na cidade encontram-se na Zona Oeste, região antigamente conhecida como Sertão Carioca, que foi a principal responsável, até as últimas décadas do século XX, pelo fornecimento de boa parte dos gêneros alimentícios à cidade. Com as mudanças trazidas pela crescente urbanização desordenada e pelos projetos conduzidos pelo Estado e pelo capital financeiro transnacional, a prática de agricultura familiar na região foi sendo gradativamente invisibilizada.

Para Fernandez (2014), a invisibilidade da AU no Rio de Janeiro é resultado de um longo processo de disputas pelo poder de ocupar espaço da cidade, que afirmou os usos urbanos, turísticos, especulativos e industriais em detrimento do rural e do agrícola e da ideia da cidade como um espaço plural, voltado para todos os tipos possíveis de usos e ocupações. Nesse sentido, a AU representa uma resistência aos processos de gentrificação - enobrecimento de áreas com expulsão da população mais pobre - e especulação imobiliária e, ao mesmo tempo, uma defesa aos modos de vida e formas contra-hegemônicas de ocupação da cidade.

Nesse cenário marcado por problemas socioambientais e disputas territoriais, agricultores(as) e movimentos sociais da região vêm se organizando politicamente para reivindicar reconhecimento e políticas de fomento à agricultura familiar e à produção orgânica no município, 
como uma forma de defesa e ocupação sustentável desse território a partir do paradigma da agroecologia. Assim, várias estratégias foram criadas para fortalecer a AU e a agroecologia no Rio de Janeiro, com o trabalho de diversas organizações, assessorias técnicas e coletivos independentes, que se organizam em diferentes movimentos, com destaque para a organização em torno da Rede CAU (2014):

A Rede CAU é um movimento social que agrega pessoas e organizações para a defesa da agroecologia nas cidades. Atua junto aos quintais produtivos e lavouras, defende o consumo ético e responsável, como dimensão de luta campo-cidade, e na adequação e no acesso às políticas públicas.

Essa rede, surgida em 2009, se insere dentro da ANA e do Coletivo Nacional de Agricultura Urbana (CNAU), com a missão de fomentar a agricultura nos espaços urbanos, reunindo mais de 30 organizações, das quais participam agricultores, associações e cooperativas, representantes de instituições de pesquisa e ensino, grupos populares e entidades civis.

Ela desempenha um papel fundamental em diversas frentes, como a luta pelo reconhecimento de territórios tradicionais, pela segurança alimentar e contra a degradação ambiental. Além disso, participa de importantes instâncias de representação institucional, como o Conselho de Segurança Alimentar do município do Rio de Janeiro (Consea Rio), organizando eventos públicos, como a Semana de Alimentação Carioca, circuitos alternativos e locais de feiras agroecológicas e redes de consumo, distribuição de alimentos orgânicos, entre outras ações que ajudam a visibilizar a agricultura realizada na cidade.

Em que pese a diversidade de atores envolvidos, chama atenção o protagonismo das mulheres no desenvolvimento das iniciativas de $\mathrm{AU}$ agroecológica dentro e fora da Rede. As mulheres não só estão à frente de boa parte das experiências de produção agroecológica nos quintais produtivos e hortas comunitárias; na coordenação de ações de educação agroecológica em serviços públicos, como escolas, Centros de Referência em Assistência Social (Cras) e equipamentos da rede pública de saúde, entre outros; como, ao se organizarem em torno de um grupo 
de trabalho próprio - a roda de mulheres da Rede CAU - elas vêm (des) construindo os saberes e as práticas agroecológicas, a partir de um olhar feminista e interseccional, produzindo novas posicionalidades e territórios existenciais no cotidiano, com reverberações importantes no que diz respeito à pauta do direito à cidade e à diversidade das experiências urbanas e circulação na cidade.

Partiremos das reflexões formuladas a partir de rodas de conversa promovidas pelas mulheres da Rede CAU em diferentes ocasiões, entre os anos de 2015 e 2017. Participamos ao todo de oito rodas, além de vários eventos, encontros, festas e conversas informais do grupo. Essas rodas são realizadas periodicamente entre as mulheres da Rede para avaliar sua atuação em seus respectivos territórios, conversar sobre problemas, possibilidades, pensar ações conjuntas e reafirmar os princípios de luta coletiva. Nesses momentos, é comum a realização de uma mística antes da reunião, para reafirmar o propósito coletivo, na qual são lidas poesias, realizadas performances e dinâmicas de grupo inspiradas em referenciais, como a proposta do Teatro do Oprimido.

A roda de mulheres da Rede $\mathrm{CAU}^{7}$ começou em 2013, a partir de alguns "buchichos" entre mulheres que integravam a Rede, mas que sentiam que suas práticas enquanto agricultoras, militantes e articuladoras nas comunidades eram menos valorizadas que o trabalho e a atuação dos homens. Uma série de conflitos internos nos espaços mistos de militância da Rede se deu, até que as mulheres entenderam a necessidade de um lugar e de estratégias de atuação próprias.

A roda inclui agricultoras, artesãs, pesquisadoras, educadoras populares e militantes de diversas lutas. Participam, em média, 40 mulheres. A despeito da diversidade das militantes da Rede, há um protagonismo maior das mulheres negras moradoras de territórios quilombolas, periféricos e favelas, especialmente da Zona Oeste e Zona Norte da cidade.

7 Destaca-se, também, nesse processo, a atuação do Instituto Políticas Alternativas para o Cone Sul (Pacs) e da Agricultura Familiar e Agroecologia (AS-PTA), duas organizações que tiveram um papel central na organização das mulheres desde o início das atividades da Rede CAU. 
As ações das mulheres da Rede são mobilizadas, de acordo com a fala das ativistas, por um "feminismo popular e periférico e pela luta antirracista”. Essa articulação com a luta feminista, entretanto, foi sendo construída aos poucos pelo grupo. É perceptível nas falas das militantes uma ideia acerca dos feminismos enquanto um movimento social que foi historicamente liderado por mulheres brancas, acadêmicas, heterossexuais e de classe média que, em suas lutas pelos direitos das mulheres e contra as desigualdades de gênero, muitas vezes invisibilizaram a organização em torno das pautas, demandas e lutas das mulheres negras e periféricas.

Por outro lado, podemos ver que existe uma construção de um movimento de mulheres que traz demandas e estratégias de lutas específicas. Utilizamos, aqui, o conceito de "feminismo periférico" para entender como se dão as construções feministas nesse contexto. "Feminismo periférico" é uma expressão usada por uma das interlocutoras na pesquisa, Saney Souza - mulher negra, trabalhadora da rede de assistência social do município e militante do Comitê Popular de Mulheres da Zona Oeste -, para descrever a luta das mulheres da agroecologia do Rio de Janeiro. O feminismo periférico parte do olhar "subalterno", questionando as formas estabelecidas de vivenciar a política e a cidade, reivindicando um feminismo local, que necessariamente considera as intersecções de classe e raça no que se refere às desigualdades sociais.

Essas reflexões trazidas por nossas interlocutoras, enquanto autoras feministas-militantes agroecológicas, relacionam-se com um conjunto de debates que vem sendo produzido por mulheres não brancas ou que foram colocadas, historicamente, em lugares de subalternidade. Chandra Mohanty (2008) aponta que as feministas ocidentais brancas tomam a cultura de classe média urbana como norma e classificam as experiências das mulheres negras, indígenas, de comunidades tradicionais do Sul global a partir de uma construção discursiva acerca das mulheres do "terceiro mundo" como necessariamente pobres, ignorantes, domésticas, exploradas sexualmente e, principalmente, sem agência, ou seja, sem capacidade de pensar e agir reflexivamente e com intencionalidade sobre a própria vida e as instituições sociais. Nesse sentido, as mulheres não 
brancas do Sul, a partir dos atravessamentos entre raça, classe, gênero e sexualidade, em sua dupla exclusão, são vistas como não humanas e não mulheres. Assim, com base no feminismo periférico, as mulheres da Rede CAU constroem um movimento agroecológico próprio, a partir de uma leitura interseccional das desigualdades, propondo estratégias de atuação que passam pela politização do cotidiano e dos corpos.

Carol Hanish (1970), a partir da sua experiência com grupos de reflexão entre mulheres nos anos 1960, cunhou a frase "o pessoal é político", como forma de entender como os problemas pessoais e de ordem íntima das mulheres são, na verdade, construções sociais e políticas. Essa frase, amplamente utilizada pelas feministas a partir da segunda metade do século XX, nos aponta para a rede de relações, campos de forças e agenciamentos que nos atravessa enquanto corpo que habita uma determinada sociedade, tempo, contexto: "Nossos corpos são nossos eus; os corpos são mapas de poder e identidade". (HARAWAY, 2000, p. 96) Para Haraway (2000), entender como esse corpo se constitui é também construir uma teoria da diferença social, entendendo as condições históricas de produção e reprodução do conhecimento sobre ele.

No campo da agroecologia, o corpo e suas tecnologias constitutivas, de alimentação, consumo e autocuidado são tomados em sua dimensão política, na medida em que são vistas a partir do seu viés de construção cultural, econômica, produtiva, ambiental. Nas conversas realizadas na roda de mulheres, a discussão sobre o que elas chamam de "corpo-território" foi reivindicada para entender o contexto de acirramento dos conflitos ambientais e a forma como a violência perpetrada pelo modelo dominante de desenvolvimento representa, para elas, uma forma de violência que avança sobre seus corpos. A noção de território engloba dimensões materiais e subjetivas, pois são lugares de experiências vividas por meio dos significados e representações individuais e também compartilhadas sobre determinado contexto.

Dessa forma, essas mulheres ampliam a compreensão sobre o corpo enquanto primeiro território de resistência e luta política. Para Silvia Baptista, quilombola, agricultora e feminista que integra a Rede, "para 
ser militante é necessário, antes de tudo, recuperar o poder sobre o próprio corpo". Nesse sentido, há um entendimento de que, para enfrentar as ameaças e os conflitos sobre os territórios, é preciso que haja uma imersão das mulheres em suas próprias histórias, situando sua existência enquanto corpo-território que sofre pressões e ameaças diversas, mas que encontra, nas práticas cotidianas, estratégias para avançar em sua autonomia individual e coletiva.

O modelo camponês - entendido, de forma ampla, como modelos familiares de produção agrícola e extrativista - surge, nesse contexto, como uma construção de um ideal de relações sociais e de produção, que tem como centro a solidariedade e a igualdade entre os sujeitos. (SILIPRANDI, 2015) Entretanto, como já foi amplamente debatido na literatura, há uma divisão social e lugares bem definidos na lógica camponesa para homens, mulheres e jovens, sendo, de fato, uma idealização. Esse modelo camponês é reivindicado pelas mulheres que compõem o movimento, ao mesmo tempo em que é constantemente questionado, em especial, no que se refere às relações de gênero e ao ideal de família camponês e da agricultura familiar.

Assim, as mulheres vão pautar, em suas discussões, questões como a invisibilidade do trabalho feminino na agricultura, o não compartilhamento das tarefas domésticas e do cuidado com os filhos e a importância de valorizar o trabalho de todos os membros da família na agricultura. Ao mesmo tempo, somam-se a essas questões problemáticas referentes ao espaço urbano - ou próximo à cidade - em que vivem e que, em diferentes graus, podem ser reconhecidas na realidade de qualquer grande metrópole latino-americana, tais como a violência urbana, a presença de milícias, a favelização e a dificuldade de locomoção entre os bairros da cidade.

A agroecologia aparece como um diferencial. É entendida como uma forma de ressignificar a relação das pessoas com o território em que vivem e de repensar as relações sociais, de educação, de trabalho e de alimentação para além da questão da produção. Silvia exalta a importância da agroecologia como uma forma alternativa de construir a luta política: 
Sou muito agradecida ao campo da agroecologia que traz essa potência enorme, de estar existindo aqui, a gente sabe que a barbárie está no limite, mas eu estou vivenciando essa outra realidade de construção de alternativas de uma economia real, de realmente construir a vida. Eu não sou inocente, conheço bem os riscos, mas o que motiva a levantar é essa terra de cuidados que a gente constrói e aí eu acho que a gente deve esclarecer nossas possibilidades de resistência e expansão dessa rede de cuidados, de solidariedade pragmática e construção de outro mundo e eu sinto que eu vivo esse outro mundo. (Silvia Baptista, diário de campo, 2016)

A centralidade que as crianças têm nas reuniões e encontros de agroecologia é um exemplo significativo desse processo. Criou-se uma metodologia de trabalho com as crianças pequenas que acompanham suas mães nas reuniões - a ciranda agroecológica -, na qual as mães e outras mulheres vão se revezando no cuidado, que é sempre discutido coletivamente. Diversas mães que participam da Rede apontam como essa relação com as crianças na roda é um diferencial em relação aos espaços mistos de militância, mesmo na agroecologia, em que as crianças, em geral, não são bem-vindas ou não são cuidadas de forma coletiva pelo grupo, fazendo com que as mulheres que são mães não possam participar ativamente das reuniões.

A alimentação também aparece como uma questão central. As mulheres se referem a ela e à saúde - pessoal e das suas famílias como as principais motivações para engajamento na agroecologia, ressaltando que a mesma é essencial para a segurança e soberania alimentar. Aliadas à ideia de resgate das culturas alimentares "tradicionais", as mulheres também experimentam formas alternativas, como a alimentação crua, o slow food ${ }^{8}$ e o vegetarianismo. Uma discussão muito presente, entretanto, é a necessidade de essas práticas alimentares se tornarem acessíveis para as populações mais pobres e moradoras de bairros periféricos. Nos debates feitos por essas mulheres, há uma grande crítica

8 Movimento que se opõe política e filosoficamente à massificação e padronização alimentar oferecidas pelo fast-food. Há um resgate de ingredientes, técnicas tradicionais de preparação dos alimentos e de culturas alimentares. 
ao discurso que envolve a alimentação saudável, que é facilmente capturado pelo imaginário do consumo do fitness, como estratégias de construção do corpo magro, e normatizado para os padrões higienizados, vendidos por veículos de mass-media como o “corpo ideal”. Em uma das rodas de mulheres, uma militante fez uma interessante colocação sobre o tema do acesso à alimentação e o discurso midiático: "Às vezes a gente vê na televisão que o melhor ômega 3 é o do Canadá, mas e as nossas plantas daqui. Por que não promover o que está acessível?”. (Juliana, diário de campo, 2017) A importância de construir uma agroecologia a partir da periferia é, portanto, constantemente reafirmada, nas palavras das militantes: "nossa agroecologia é preta e periférica". (Roda de mulheres da Rede CAU, diário de campo, 2017)

Várias estratégias são construídas pelas mulheres da Rede para promover o acesso a alimentos saudáveis nas periferias. Uma delas vem sendo desenvolvida por Ana Santos, agricultora moradora do Complexo da Penha, Zona Norte do Rio, que coordena a organização não governamental Centro de Educação Multicultural (CEM). Ela compra semanalmente a "xepa" de todas as barracas da feira orgânica do bairro de Olaria e sobe o morro vendendo as verduras pelo preço de $R \$ 0,50$. Outra ação também realizada por Ana é vender, uma vez por semana, as verduras por ela produzidas dentro dos trens que percorrem a periferia da cidade. O comércio dentro dos trens é uma prática amplamente realizada, em especial em estações mais distantes do centro da cidade. É comum, nessas ocasiões, a venda de produtos comestíveis ultraprocessados, de baixo valor nutricional, alto valor de açúcar e preços muito baixos. Assim, segundo Ana, vender verduras tem sido um diferencial bem-vindo pelos clientes que, muitas vezes, passam até quatro horas diárias dentro dos vagões para ir e voltar ao trabalho.

Os rituais de comensalidade também são centrais no movimento construído por essas mulheres - o "comer junto" é um fator de sociabilidade, além de ser uma forma de chamar a atenção para a importância

9 Restos de alimentos que não foram vendidos na feira. 
da alimentação consciente daqueles que ainda não aderiram à produção e ao consumo de produtos agroecológicos. Para Appadurai (1981 apud CARMO, 2013) é impossível dissociar a dimensão política da alimentação, destacando que a comida pode ser o meio, ou mesmo a mensagem, pelo qual conflitos acerca de recursos culturais ou econômicos se estabelecem. O autor utiliza a categoria analítica "gastropolíticas" (gastro-politics) para fazer menção a contextos:

[...] quando a comida é manipulada de modo a levar mensagens entre os atores, embora eles possam compartilhar os significados fundamentais do sistema [...], [eles] estão envolvidos numa luta acerca de uma particular cadeia sintagmática dos eventos alimentares nos quais estão envolvidos. (APPADURAI, 1981 apud CARMO, 2013, p. 18)

Dessa forma, observa-se que existe uma politização da esfera do privado (a alimentação) e do consumo. Os rituais de comensalidade são mecanismos para a consolidação da solidariedade grupal, pois envolvem a partilha não só de alimentos, mas de significados: é o momento de conversar sobre as atividades ocorridas ou por acontecer, estabelecer novos contatos ou simplesmente "jogar conversa fora". No contexto das reuniões, nas feiras e nos encontros de agroecologia, é comum acontecer, em grandes “cafés da manhã agroecológicos", no quais se percebe que partilhar alimentos é também partilhar sentidos atribuídos aos principais significantes em jogo, como sororidade, ${ }^{10}$ corpo e alimentação. Desse modo, a comensalidade é politizada ao serem atribuídos valores políticos à partilha e feitura dos alimentos a serem compartilhados. (CARMO, 2013)

Há uma busca pela alimentação consciente, assim como o resgate da produção e consumo de gêneros alimentícios tradicionais esquecidos ou pouco usados, como a taioba e ora-pro-nóbis - Plantas Alimentícias Não

10 "Sororidade" vem de sóror, que significa "irmã" em latim. Essa expressão é utilizada por parte do movimento feminista para designar uma solidariedade que seria própria das mulheres, assim como a fraternidade se referiria à solidariedade entre fraters - irmãos. Existem muitas críticas a esse termo dentro dos feminismos, mas, em não sendo nosso objetivo no texto, apenas apresentamos essa expressão por ela ser constantemente utilizada pelas interlocutoras da presente pesquisa. 
Convencionais (Panc) -, assim como uma valorização dos saberes das medicinas populares, com a disseminação do uso de ervas, chás, lambedores e xaropes caseiros que remetem à ideia de ancestralidade, um aspecto importante para entender a formação da identidade e o vínculo dessas mulheres nos territórios em que vivem.

A culinária é, portanto, uma das grandes estratégias de mobilização desses grupos. A primeira autora do presente texto participou algumas vezes de oficinas de beneficiamento de frutas em feiras agroecológicas, além de ter cozinhado em alguns encontros organizados por coletivos de agroecologia. Nessas ocasiões, realizou-se uma "cozinha de transição agroecológica", misturando alimentos "naturais" com alimentos como pães, salgados e sobremesas, como forma de atrair mais pessoas para experimentar.

A comida, sem dúvida, mobiliza as comunidades, ao mesmo tempo em que é um elemento que remete aos lugares tradicionalmente identificados como femininos. Essa relação, entretanto, ganha outros significados nesses movimentos. Uma das interlocutoras relatou, em uma conversa informal, que durante toda a vida rechaçou o espaço da cozinha e da culinária, pois, para ela, isso a identificava com a ideia de mulher submissa e do lar. Entretanto, a partir do momento que ela entrou no movimento da agroecologia, percebeu a potência que a cozinha tem para agregar pessoas em torno de uma causa comum. Esse aspecto é particularmente interessante quando pensado sobre as mulheres que historicamente ocuparam o lugar da cozinha, entendida como um espaço de subalternidade: mulheres negras, pobres, donas de casa.

Ao mesmo, as militantes apontam que, nos espaços mistos, as mulheres são naturalmente designadas para ocupar o lugar da cozinha e da organização da logística, enquanto os homens ficam com a fala e os processos decisórios, em uma dinâmica que foi sendo modificada ao longo da auto-organização das mulheres na roda, revelando um maior protagonismo de fala das agricultoras. Ainda assim, elas apontam que é difícil conciliar os afazeres domésticos com a militância. A maior parte delas relata que, a despeito de terem maior consciência e conseguirem 
se colocar em casa no que se refere ao compartilhamento das tarefas domésticas e da gestão financeira, ainda é comum faltar às reuniões políticas por não poder se ausentar do trabalho de casa, ter que tomar conta dos filhos, cuidar da horta, dentre outras questões.

Tais conflitos mostram que, apesar da inserção da temática de gênero nos grupos de agroecologia, muitas vezes esse debate ainda é pautado e entendido como "coisa de mulher", não sendo construído nos espaços mistos de militância. Como Ramos (2017, p. 63) ressalta, isso "enfraquece o potencial emancipatório anunciado pela agroecologia, impedindo que haja o reconhecimento de relações e/ou situações de opressão e/ou subordinação às quais as mulheres estão envolvidas".

Percebe-se, assim, que as lutas de resistência em que as mulheres, na agroecologia urbana, estão envolvidas - pelo reconhecimento da agricultura na cidade do Rio de Janeiro, pelo acesso a políticas públicas de incentivo à agricultura familiar e contra a especulação imobiliária apontam para uma direção comum, qual seja, um modelo de desenvolvimento com relações de menor impacto no que se refere à produção/ distribuição de alimentos e apropriação da natureza, fugindo à lógica capitalista que se apoia na reprodução das desigualdades socioeconômicas, raciais e sexistas.

\section{CONSIDERAÇÕES FINAIS}

Ao mesmo tempo em que o capitalismo mundial integrado ${ }^{11}$ amplia a hegemonia de um determinado modelo de desenvolvimento e a determinados regimes de produção neoliberal, assiste-se ao aparecimento de vários contramovimentos e estratégias de resistência, como a agroecologia, os feminismos, o movimento de direito à cidade, os movimentos pela Reforma Agrária e o movimento de $\mathrm{AU}$, que não possuem um formato único e tampouco têm causas inteiramente comuns, mas

11 Conceito de Guattari (1992) que se refere à produção de subjetividade e sistema de governo no contexto global. 
mobilizam sujeitos e coletivos, tanto nos campos quanto nas cidades, evidenciando a grande confluência das crises que afligem as sociedades contemporâneas. Nesse sentido, ao pensar a agroecologia nas cidades, como apontam Suzuki e Berdoulay (2016, p. 11), já não estamos mais falando apenas da dimensão produtiva dos cultivos, mas:

[...] do seu significado utópico de outra cidade, em que se busca criar outra relação com o verde e a biodiversidade, bem como de estabelecer novos parâmetros de relação entre os citadinos e com o ambiente urbano, em que a ajuda e a troca de conhecimentos, tão presentes na tradição rural, estejam presentes na expansão da agricultura urbana em suas diversas e variadas faces como mediação necessária para o futuro da sociedade urbana, semeando novas cidades.

A partir dessas diversas articulações e dos diferentes engajamentos que atravessam a militância agroecológica, percebemos que, ao pensar não só a transformação de todo o processo de produção agrícola, mas também a profunda reconfiguração das relações capitalistas, racistas, antropocêntricas e patriarcais que estruturam as ciências, as tecnologias e o socius de maneira geral, o movimento agroecológico nos dá pistas sobre formas de articulação combativas à tentativa massificadora do projeto neoliberal, ao mesmo tempo em que traz mudanças nas formas de participação política nas cidades.

Ao reivindicarem outros usos possíveis de ocupação da cidade, construindo uma atuação a partir da politização das práticas cotidianas que ressignificam lugares historicamente subalternizados, como o da agricultura e da cozinha, essas mulheres vêm construindo, na luta agroecológica periférica e feminista, outras formas de experiência urbana e com a cidade em direção a modos de vida mais sustentáveis. O processo de ganho de autonomia e desconstrução das relações desiguais de gênero, entretanto, ainda é um grande desafio para essas mulheres, expresso em conflitos na esfera doméstica, mas também em espaços públicos e mistos da militância em movimentos sociais.

Desse modo, acreditamos que as rupturas propostas pela agroecologia feminista e periférica buscam se constituir enquanto linhas de fuga ao 
poder da máquina capitalista de produção de subjetividade - uma recusa que visa construir novos modos de sensibilidade e criatividade nas cidades.

\section{REFERÊNCIAS}

AMADOR, F. S.; FERNANDES, D. R. Cidades (in)habituais: considerações sobre neoliberalismo e resistência. Fractal: Revista de Psicologia, Niterói, v. 28 , n. 2, p. 252-256, 2016. Disponível em: http://dx.doi.org/10.1590/19840292/1459. Acesso em: 14 jul. 2019.

AQUINO, A. M.; ASSIS, R. L. Agricultura orgânica em áreas urbanas e periurbanas com base na agroecologia. Ambiente \& Sociedade, São Paulo, v. 10, n. 1, p. 137-150, 2007.

BENTO, D. F. M. C. R. A importância do ambiente obesogênico na população de alta vulnerabilidade social em Campinas/SP. 2017. Tese (Doutorado em Saúde Coletiva) - Universidade Estadual de Campinas, Campinas, 2017. Acesso em: http://repositorio.unicamp.br/bitstream/REPOSIP/325309/1/ Bento_DanieleFlavianeMendesCamargoDaRocha_D.pdf. Acesso em: 14 jul. 2019.

BRASIL. Lei n. 10.257, de 10 de julho de 2001. Regulamenta os arts. 182 e 183 da Constituição Federal, estabelece diretrizes gerais da política urbana e dá outras providências. Diário Oficial [da] República Federativa do Brasil, Brasília, DF, 2001.

BRITTO, F. D.; JACQUES, P. B. Corpocidade: arte enquanto microresistência urbana. Fractal: Revista de Psicologia, Niterói, v. 21, n. 2, p. 337-350, 2009.

CARMO, I. N. Viva o feminismo vegano: gastropolíticas e convenções de gênero, sexualidade e espécie entre feministas jovens. 2013. Dissertação (Mestrado em Estudos Interdisciplinares sobre Mulheres, Gênero e Feminismo) - Universidade Federal da Bahia, Salvador, 2013. Disponível em: https://repositorio.ufba.br/ri/bitstream/ri/18540/1/ Disserta\%C3\%A7ao\%20de\%20\%C3\%8Dris\%20Nery\%20do\%20Carmo.pdf. Acesso em: 14 jul. 2019.

COSTA, D.; CIPOLLA, C. Agricultura urbana: identificação de oportunidades de projeto para o processo produtivo e comercialização. MIX Sustentável, Florianópolis, v. 2, n. 1, p. 114-120, 2016. 
DELEUZE, G.; GUATTARI, F. Mil platôs: capitalismo e esquizofrenia. Tradução de Aurélio Guerra Neto e Celia Pinto Costa. Rio de janeiro: Editora 34, 1995. (Coleção TRANS, v. 1).

DEPARTMANT OF ECONOMIC AND SOCIAL AFFAIRS - DESA. World urbanization prospects. New York: United Nations, 2014. Disponível em: https://esa.un.org/unpd/wup/Publications/Files/WUP2014-Report.pdf. Acesso em: 14 jul. 2019.

DURAN, A. C. F. L. Ambiente alimentar urbano em São Paulo, Brasil: avaliação, desigualdades e associação com consumo alimentar. 2013. Tese (Doutorado em Ciências) - Universidade de São Paulo, São Paulo, 2013. Disponível em: http://www.teses.usp.br/teses/disponiveis/6/6138/ tde-02102013-164136/pt-br.php. Acesso em: 14 jul. 2019.

FERNANDEZ, A. C. F. Eu vivo da natureza: resistência e conversão agroecológica de produtores na cidade do Rio de Janeiro. Revista Espaço de Diálogo e Desconexão, Araraquara, v. 8, n. 1-2, p. 1-26, 2014.

FÓRUM SOCIAL MUNDIAL - FSM. Carta mundial pelo direito à cidade. Bamako, 2006. Disponível em: http://www.polis.org.br/uploads/709/709. pdf. Acesso em: 25 nov. 2017.

GUATTARI, F. Caosmose: um novo paradigma estético. São Paulo:

Editora 34, 1992.

HANISH, C. The personal is political. In: FIRESTONE, S.; KOEDT, A. (org.). Notes from the second year: women's liberation. New York: Women's Liberation Movement, 1970. p. 76-78. Tradução livre. Disponível em: https://resistenciaradfem.wordpress.com/tag/carol-hanisch/. Acesso em: 14 jul. 2019.

HARAWAY, D. Manifesto ciborgue: ciência, tecnologia e feminismosocialista no final do século XX. In: KUNZRU, H.; HARAWAY, D. J; SILVA, T. T. (org.). Antropologia do ciborgue: as vertigens do pós-humano. Belo Horizonte: Autêntica, 2000. p. 33-118.

HARVEY, D. O direito à cidade. Lutas Sociais, São Paulo, v. 29, n. 2, p. 73-89, jul./dez. 2012.

IBGE. Brasil em síntese: Rio de Janeiro: panorama. Rio de Janeiro, 2017. Disponível em: https://cidades.ibge.gov.br/xtras/temas.php?lang=\&codm un=330455\&idtema=16\&search=rio-de-janeiro|rio-de-janeiro|sintese-dasinformacoes. Acesso em: 14 jul. 2019. 
IBGE. Censo agropecuário 2006: Brasil, Grandes Regiões e Unidades da Federação. Rio de Janeiro, 2006.

JALIL, L. M. Mulheres e soberania alimentar: a luta para a transformação do meio rural brasileiro. 2009. Dissertação (Mestrado em Ciências) Universidade Federal do Rio de Janeiro, Rio de Janeiro, 2009. Disponível em: http://www.reformaagrariaemdados.org.br/sites/default/files/2009\%20 dissertacao_laeticia_jalil.pdf. Acesso em: 14 jul. 2019.

KUSTER, E. Outros olhos: as ru(s)gas da cidade e seu desvelamento nos discursos contemporâneos. In: KUSTER, E.; PECHMAN, R. M. (org.). O chamado da cidade: ensaios sobre a urbanidade. Belo Horizonte: Editora UFMG, 2014. p. 47-58.

LEDA, L. C. Sistema tradicional de varejo de alimentos e sua importância para a segurança alimentar e nutricional: o caso do Distrito Federal. 2017. Dissertação (Mestrado em Meio Ambiente e Desenvolvimento Rural) - Universidade de Brasília, Brasília, DF, 2017. Disponível em: http:// repositorio.unb.br/handle/10482/24477. Acesso em: 14 jul. 2019.

LEFEBVRE, H. O direito à cidade. São Paulo: Centauro, 2001.

MARCOS, V. Agroecologia e campesinato: uma nova lógica para a agricultura do futuro. Agrária, São Paulo, v. 7, n. 1, p. 182-210, 2007.

MOHANTY, C. Bajo los ojos de occidente: feminismo académico y discursos coloniales. In: SUÁREZ-NAVAZ, L.; CASTILLO, R. A. H. (org.). Descolonizando el feminismo: teorías y prácticas desde los márgenes. Madrid: Ediciones Cátedra, 2008. p. 117-163.

MOK, H. et al. Strawberry fields forever? Urban agriculture in developed countries: a review. Agronomy for Sustainable Development, Paris, v. 34, n. 1, p. 21-43, Jan. 2014.

PARK, R. A cidade: sugestões para investigação do comportamento humano no meio urbano. In: VELHO, O. G. (org.). O fenômeno urbano. 2. ed. Rio de Janeiro: Zahar, 1973. p. 13-28.

PRADO, B. A. Novas conexões entre o rural e o urbano. Revista Agriculturas, Rio de Janeiro, v. 12, n. 2, p. 4-7, jun. 2015.

RAMOS, F. S. Do campo à academia, da academia ao campo: as mulheres na agroecologia. Século XXI: Revista de Ciências Sociais, Santa Maria, v. 7, n. 1, p. 43-65, 2017. 
REDE CARIOCA DE AGRICULTURA URBANA - REDE CAU. Carta aberta da Rede Carioca de Agricultura Urbana. Rio de Janeiro, 2014. Disponível em: https://aarj.wordpress.com/2014/12/14/carta-aberta-da-rede-carioca-deagricultura-urbana/. Acesso em: 14 jul. 2019.

ROLNIK, S. Cartografia sentimental, transformações contemporâneas do desejo. São Paulo: Estação Liberdade, 2001.

ROMERO, M. L.; ZAMORA, M. H. Pesquisando cidade e subjetividade: corpos e errâncias de um flâneur-cartógrafo. Psicologia em Estudo, Maringá, v. 21, n. 3, p. 451-461, jul./set. 2016.

SAHLINS, M. O "pessimismo sentimental" e a experiência etnográfica: por que a cultura não é um "objeto" em via de extinção (parte II). Mana, Rio de Janeiro, v. 3, n. 2, p. 103-150, out. 1997.

SANTANDREU, A.; LOVO, I. C. Panorama da agricultura urbana e periurbana no Brasil e diretrizes políticas para sua promoção: identificação e caracterização de iniciativas e AUP em Regiões Metropolitanas Brasileiras. Belo Horizonte: Ministério do Desenvolvimento Social e Combate à Fome, 2007.

SILIPRANDI, E. Mulheres e agroecologia: transformando o campo, as florestas e as pessoas. Rio de Janeiro: UFRJ, 2015.

SILVA, R. L. Direito à cidade. In: XIMENDES, A. M. C; REIS, C; OLIVEIRA, R. W. (org.). Entre garantia de direitos e práticas libertárias. Porto Alegre: CRP-RS, 2013. p. 109-122.

SUZUKI, J. C.; BERDOULAY, V. Agricultura urbana entre necessidade e utopia: experiências paulistanas. In: COLOQUIO INTERNACIONAL DE GEOCRÍTICA, 14., 2016, Barcelona. Anais [...]. Barcelona, 2016. p. 1-14. Disponível em: http://www.ub.edu/geocrit/xiv_suzuki.pdf. Acesso em: 4 jul. 2019.

TEOBALDO, I. N. C. A cidade espetáculo: efeito da globalização. Sociologia: Revista do Departamento de Sociologia da FLUP, Porto, v. XX, p. 137-148, 2010. 



\section{De mercado à vila práticas alimentares e higiene frente ao processo de gentrificação na cidade de Salvador, Bahia ${ }^{1}$}

DIEGO MARINHO CALABRESE E LIGIA AMPARO-SANTOS

\section{INTRODUÇÃO}

Este ensaio entrecruza três temáticas distintas - gentrificação, higiene e práticas alimentares -, ao passo que se revelam complementares quando tomado como ponto de interlocução o percurso de sucessivas modificações urbanas, de infraestrutura e sociais na atual Vila Caramuru, antes

1 Estudo parte do projeto intitulado "Corporalidades, comensalidades e alimentação saudável na Bahia: um estudo sobre as práticas corporais e alimentares em camadas populares sob a ótica da promoção da alimentação saudável". Tal projeto contou com o apoio financeiro da Fundação de Amparo à Pesquisa do Estado da Bahia (Fapesb) e bolsa financiada pela Coordenação de Aperfeiçoamento de Pessoal de Nível Superior (Capes). 
Mercado do Rio Vermelho e Mercado do Peixe - nome pelo qual o espaço é mais conhecido - em Salvador, Bahia.

Os argumentos contidos neste texto emergem de inquietações surgidas em torno da necessidade de aprofundamento sobre o fenômeno da gentrificação nos espaços públicos de comensalidade dentro das cidades, no qual as feiras e os mercados populares revelam-se como importantes neste contexto, ainda que em um cenário de sucessivas intervenções urbanas que visam, por seu turno, supostamente "embelezamento", "modernização" e higienização dos mesmos.

"De mercado à vila" é parte de um estudo maior o qual objetiva compreender as práticas alimentares e de higiene perante o processo de gentrificação em curso em um espaço de comensalidade na cidade de Salvador. ${ }^{2}$

Não se trata, portanto, de um tratado teórico sobre a temática e tampouco possui a intenção de oferecer uma análise histórica sobre o fenômeno da gentrificação no locus pesquisado.

Trata-se de um estudo de cunho qualitativo e analítico, que tomou como substrato os discursos midiáticos de recortes dos principais jornais de circulação impressa em Salvador, propondo uma interlocução com escritos oriundos, particularmente, da socioantropologia da alimentação e nutrição e antropologia urbana.

A discussão se estrutura em torno do conceito de gentrificação ou gentrification (do inglês), termo cunhado em 1964 pela socióloga britânica Ruth Glass, ao se referir às alterações por ela observadas na estrutura social e mercados imobiliários em certas áreas do centro de Londres. Glass (1964, p. 17) observou:

Um por um, muitos dos bairros da classe trabalhadora foram invadidos pela classe média - alta e baixa ... Uma vez que esse processo de gentrificação inicia em um distrito, ele continua rapidamente até que todos ou a maioria dos ocupantes da classe trabalhadora sejam deslocados e todo o caráter social do distrito é alterado. ${ }^{3}$

2 Dissertação de mestrado em andamento.

3 "One by one, many of the working class quarters have been invaded by the middle class - 
Van Weesep (1994) marca a ideia de que o processo de gentrificação está profundamente enraizado nas dinâmicas sociais e nas tendências econômicas. Afirma ainda que seus sinais, efeitos e trajetórias são, em grande medida, determinados pelo seu contexto local: as características físicas e sociais dos bairros em questão, as posições e os objetivos dos atores, as funções dominantes da cidade, a natureza da reestruturação econômica e a política do governo local. Finalmente, defende-se que o "porquê" da gentrificação é menos importante que o "como" e as repercussões do processo, algo que corrobora com a visão empregada neste escrito.

Além disso, Lees, Slater e Wyly (2008) afirmam que a gentrificação tornou-se uma "valiosa lente" através da qual se dá para examinar uma variedade de fenômenos que se cruzam em um contexto de cidade e/ou vizinhança. Insere ainda no debate a ideia de "geografia do consumo" e exclusão social diante da lógica embutida no processo de gentrificação, o qual acrescentamos o empenho que gira em torno da higienização dos espaços.

Com a higiene, introduz-se um novo padrão de comportamento, montando novos mecanismos de condicionamento social, exigindo um novo pensamento, novos cálculos e, como bem afirma Brás (2008), tornou-se símbolo de sociedade bem-educada e simultaneamente de "pessoa de bem". Pontua-se, portanto, que tal ensaio se ocupará de trazer elementos de um "urbanismo higienista", ou seja, de um higienismo social, que aos olhos de Ferreira Filho (1998), há um viés ideológico nessas ações, no qual, ao final do século XIX e primeiras décadas do século $X X$, inscreve-se num projeto de modernização, de "desafricanização das ruas", guardando, de certa maneira, semelhanças com movimentos de gentrificação atuais, ao menos no Brasil.

Mercados e demais espaços de comensalidade revelam-se alvos privilegiados de tais iniciativas que partem do poder público, bem como

upper and lower ... Once this process 'f 'gentrificat'on' starts in a district it goes on rapidly until all or most of the working class occupiers are displaced and the whole social character of the district is changed". 
do setor privado movidos por uma lógica neoliberal. Sob adjetivos eufemistas que maximizam características positivas do processo, percebe-se uma reflexão crítica insuficiente sobre o processo de gentrificação nesses espaços, seus efeitos diante de possíveis mudanças no perfil dos frequentadores e, consequentemente, nas práticas alimentares.

Em seu Guia de ruas e mistérios, Jorge Amado nos leva a viajar pelas ruas da cidade da Bahia e traz consigo uma definição poética que nos faz refletir sobre espaços comensais populares - em particular, o Mercado do Peixe - e o que abordamos como práticas alimentares populares:

Esses são os mercados populares. [...] dão direito à conversa solta e sem pressa, ao trago da cachaça, ao caldo da lambreta, ao vatapá oloroso, ao sarapatel de miúdos de porco. Não é possível comparar os frios mercados da sociedade de consumo com esses cálidos centros de vida popular. (AMADO, 1991, p. 398)

As práticas ligadas à comensalidade popular se expressam não apenas pelo que se é consumido, neste caso, as comidas do cotidiano ou encaradas como "pesadas", mas também pelos modos de interação e sociabilidade dos sujeitos, maneiras à mesa, até mesmo a apresentação das refeições, sob o ponto de vista estético. Desta maneira, entende-se aqui que o processo de gentrificação e consequente higienização em tais espaços refletem diretamente nas práticas alimentares de seus frequentadores, dadas sucessivas tentativas de formalização das relações interpessoais, do câmbio do perfil da clientela e até mesmo da comercialização de versões mais "gourmetizadas" e caras de pratos tradicionais, oferecidas ao consumidor como uma forma simbólica de marcar diferenças sociais.

Diante da tamanha complexidade e da dinâmica construção do fenômeno, este ensaio se estruturará a partir da consideração dos elementos que se imbricam em torno da problemática. Desejando seu melhor entendimento, pretende-se trazer uma abordagem a partir dos diferentes momentos do Mercado, destacando seus eventos históricos, suas relações com o processo de gentrificação e higienização, e, finalmente, serão abordadas possíveis modificações no campo das práticas alimentares. 


\section{DE MERCADO À VILA}

Ideias urbanísticas de modernização e higienização, como as do barão Haussman, em Paris, que circularam por todo o mundo, sobretudo seus feitos mais autoritários, tiveram suas reproduções brasileiras, apesar do contexto urbano bastante distinto. Em Elogios aos errantes, Jacques (2012) nos leva a uma viagem ao longo do tempo, trazendo diferentes perspectivas de alguns personagens reais que escreveram sobre o período de rápida metamorfose urbana na cidade do Rio de Janeiro no início do século XX. É nesse período que Olavo Bilac, por exemplo, exaltava, apoiava e enaltecia os feitos da reforma do prefeito - viva "as picaretas regeneradoras!”. Já Lima Barreto, diferentemente, era avesso a tudo o que se referia à modernização: a nova avenida, disse ele, é como uma “mulata apertada em vestido francês”. Por sua vez, João do Rio se colocava em um difícil meio-termo: ao mesmo tempo em que criticava a radicalidade e o autoritarismo do momento, sabia que também faziam parte desse processo modernizador, que se mostrava inevitável. A autora então afirma que a ambiguidade era inerente a uma crítica moderna da própria modernidade, ao dialogar com a perspectiva "errante" de João do Rio.

Semelhanças ocorrem na cidade de Salvador, com a figura do prefeito J. J. Seabra (1912-1916), que, como bem nos lembra Santos (2008), há um clássico exemplo da destruição da tradicional Igreja da Sé, palco dos famosos discursos do padre Antônio Vieira durante o século XVI, para possibilitar a circulação dos bondes no centro da cidade. Tal fato gerou inúmeras polêmicas, debates e repúdios nos meios intelectuais e jornalísticos.

Todavia, é importante destacar que foi nas décadas de 1950 e 1960 que se assentaram as bases para o desenvolvimento técnico e econômico do estado da Bahia que, como apontado por Santos (2008), houve a existência de um processo de modernização mais intenso e próximo de uma lógica urbano-industrial em curso na cidade, que, nas décadas de 1980 e 1990, se acentua drasticamente tomando, possivelmente, novos contornos com a economia da cidade voltada ao setor de serviços. Salvador, 
segundo Risério (2004), passa a ser uma cidade centrada na "economia do lazer”, pautada nos elementos turísticos, do lúdico e do simbólico.

Contudo, essas iniciativas modernizantes pouco alteraram a configuração e a dinâmica da cidade. A metrópole Salvador, ainda que como espaço periférico, integra os movimentos da era globalizada, entretanto, incorpora-os ao modo próprio como equaciona sua herança histórica e a atualiza.

Assim, o Mercado do Peixe, marcado pela linha tênue entre manutenção da tradição e abertura à modernidade, revela-se como rico espaço para se discutir a atualidade dos projetos de assepsia, limpeza social, vigilância, privatização e controle urbano, em um contexto de comensalidade e sociabilidade popular. Tal processo se dá em meio a uma eterna luta que a urbe ainda trava contra o estigma de "cidade suja", criado pelas escritas dos viajantes que aqui chegavam há mais de dois séculos atrás. (ARAUJO, 2006)

Em uma conjuntura citadina, cabe salientar a relevância dos bairros como espaços de atuação. Como bem aponta Certeau (1994), o bairro é uma categoria importante para se pensar a configuração das relações dos habitantes da cidade com o espaço. Diante disso, de início mostra-se importante trazer algumas questões que marcam o bairro do Rio Vermelho, onde está localizado o espaço do Mercado, questões essas que nos permitem compreender as dinâmicas que giram em torno da ideia de tradição e modernidade, envoltas no processo particular de gentrificação do espaço.

De maneira breve, o mito de origem do Rio Vermelho se funda no naufrágio de Diogo Alvares, o Caramuru, no século XVI. Bem acolhido pelos índios tupinambás que por lá viviam, Caramuru logo passou a ser estimado na região, onde conheceu a índia Catarina Paraguaçu, com quem se casou. Já no século XVII, logo após a Invasão Holandesa em 1624, moradores se instalam no local. Aos poucos, o bairro, predominantemente formado por pescadores, passou a servir de veraneio para as famílias ricas da cidade.

Atualmente, o bairro circula entre os principais destinos boêmios de Salvador. Estão ali alguns dos largos e baianas de acarajé mais famosos 
da cidade, além de cafés, restaurantes, diversos bares e o Mercado do Peixe. Além disso, o lugar é bastante disputado pelo mercado imobiliário e também é tido como um recanto de artistas, intelectuais, estudantes universitários ou, como denomina Lees, Slater e Wyly (2008), de "classe criativa". ${ }^{4}$

As ruas do Rio Vermelho também abrigam uma das maiores festas populares de Salvador: a Festa de Iemanjá. ${ }^{5} \mathrm{O}$ antigo Mercado do Peixe, antes de ser transformado em Vila Caramuru, participava desses festejos, era enfeitado com as cores que remetem a Iemanjá, azul e branco, e atraía uma diversidade de público. Tal contexto se modifica com o atual instalado e guarda semelhanças com modelos de festas particulares já inseridas no cenário "camarotizado"6 da cidade, tal como ocorre na

4 No Rio Vermelho, moraram artistas ilustres do cenário local e nacional, como: Carlos Bastos, Carybé, Jenner Augusto e Mario Cravo - além do casal de escritores Jorge Amado e Zélia Gattai, cuja casa hoje é um museu, a Casa do Rio Vermelho -, que transitaram lado a lado com os moradores da arte musical, como o pianista Carlos Lacerda, a musicista Walkyria Knittel, ou ainda das artes cênicas, como João Miguel. Talvez impulsionados por esses antigos moradores que, aos poucos, inúmeras galerias e ateliers de artes plásticas surgiram e definiram o bairro como referência em artes. (CALABRESE, 2013, p. 36)

5 Segundo Manoel Quirino (1946), a notícia mais antiga em relação aos festejos dedicados à Rainha das Águas foi a descrição da festa, pelo referido autor, no século XIX, quando os organizadores da festa ainda eram escravos africanos e o evento ocorria em outro espaço. O formato mais próximo ao atual apresenta-se desde o ano de 1923, como a maior manifestação pública do candomblé em Salvador, criada por pescadores para reverenciar a Mãe D’Água, em forma de apelo, num momento de baixa na pesca. Assim, todos os anos, no dia 2 de fevereiro, enchem-se balaios de flores e de presentes para a Rainha do Mar, e festejos que são acompanhados por barracas em toda a extensão da orla, com desfiles de blocos, apresentações de batuques, afoxés e sambas de roda, fazendo da localidade um celeiro de criatividade, aliando-se a isso diversos tipos de apresentações e manifestações, inclusive as político-partidárias. Agregam-se ainda eventos paralelos, tais como as famosas feijoadas. (SILVA, 2006, p. 113)

6 Entende-se por "camarotização" o processo iniciado na década 1980, em Salvador, com a introdução de "dinâmicas típicas do mundo dos negócios, dando lugar à configuração do que pode ser chamado de carnaval-negócio, marca registrada que particulariza a forma contemporânea do Carnaval da Bahia". (MIGUEZ, 2011, p. 287) Insere-se nesse contexto a instalação de gigantes camarotes nos percursos do Carnaval, em que, em um movimento de apropriação do espaço público, são realizadas festas particulares com áreas VIP. Dialogando com o contraste percebido por DaMatta (1997, p. 35), em referência aos Carnavais de rua e aos Carnavais de clube, sendo "um Carnaval que é aberto - no sentido literal e metafórico da expressão - e um Carnaval que é fechado e tem tendências aristocratizantes", respectivamente. 
Festa do Senhor do Bonfim e Nossa Senhora da Conceição com suas versões "light".

O Mercado do Rio Vermelho - ou melhor, Mercado Municipal do Rio Vermelho -, oficialmente, nasce com formato de feira em um galpão fechado que funcionava durante o dia, conformação diferente da atual, localizado no Largo da Mariquita - do outro lado da rua -, em que eram comercializados peixes, frutos do mar e também havia alguns espaços destinados à comercialização de comidas e bebidas.

Um trecho de reportagem da década de 1970 revela um pouco como era o espaço e como o mesmo era visto por alguns moradores do bairro:

Também [em comparação ao bairro do Rio Vermelho, à época] sem nenhuma estrutura, ou sistema higiênico, funcionam no Largo, uma peixaria e um mercado, que na realidade são verdadeiros atentados à saúde pública. A peixaria exala um odor insuportável, sentido até por quem passa de veículo. O mercado público é um antro de desocupados e alcóolatras. Como bem disse uma senhora residente na área, 'nenhuma mulher que se preza entra neste mercado'. As barracas de comida ali estabelecidas, jogam o lixo na calçada do mercado, ou seja, no próprio largo. [...] para uma criança ou uma senhora atravessar a Mariquita, é preciso ter muita paciência e tempo. Além do mais, inexplicavelmente, o Largo tem o poder de atrair vários malucos. (LARGO..., 1976, p. 6)

A casa e a rua são referidas por DaMatta (1997) sob diferentes concepções em uma ordem decrescente de segurança e organização, respectivamente. No trecho acima, a rua é encarada como espaço da marginalidade, da malandragem, da vagabundagem, da loucura e da falta de higiene.

É possível que a senhora entrevistada, de maneira inconsciente ou não, em um movimento de distanciamento pautado em um discurso moralizado, perceba tal espaço e os sujeitos que o frequentam como

7 "Nas festas da Conceição e do Bonfim, há outras festas em paralelo que se denominam respectivamente Conceição Light e Bonfim Light. Ambas são festas privadas em espaços localizados no entorno, voltadas para um público jovem de classe média e alta, ou seja, festa para 'gente bonita'. Oportuniza que todos 'rendam homenagens' aos santos católicos e aos orixás, mas numa festividade mais light, não precisa se misturar ao povo miscigenado com hábitos e atitudes mais 'pesadas'. Em suma, festa é signo da cultura baiana que hoje se transforma em um produto que percorre a cidade". (SANTOS, 2008, p. 129) 
elementos "sujos", concordando com Douglas (2014), quando marca que a sujeira seria essencialmente a desordem, principalmente para o bairro do Rio Vermelho que, àquela época, era ocupado por casas de veraneio da classe média e alta.

Determinado entendimento corrobora com o que aponta Araujo (2006) sobre a noção de que "classes pobres" e "classes perigosas" - expressão cunhada possivelmente no início do século XIX - eram duas expressões que denotavam e descreviam a mesma "realidade".

Dessa maneira, as classes populares passaram a ser vistas naturalmente como classes perigosas, já que, além de oferecer problemas para a organização do trabalho e da manutenção da ordem pública, ofereciam perigo sob o ponto de vista higiênico.

Na década de 1980, o Mercado do Peixe, então, é transferido para o outro lado da rua, mais próximo ao mar, e, por certo tempo, as características de feira foram mantidas. Contudo, o comércio das comidas e bebidas se expandiu, predominando no espaço, restringindo progressivamente a feira.

O Mercado do Peixe, então, assume definitivamente o aspecto boêmio do bairro do Rio Vermelho, mas ainda mantendo sua característica popular. É marcada a tradição do Mercado, se afirmando como a melhor opção da cidade para a famosa "saideira". ${ }^{8}$ Nesse período, o então Mercado do Peixe, localizado à beira-mar e com diversos bares no mesmo ambiente, se consolida como espaço popular foi mantida ainda que a época seus preços fossem questionados - tendo como símbolo o conhecido "feijão da madrugada", já que o mesmo passou a funcionar 24 horas:

Festa de jornalista, intelectual e artista que se preze costuma terminar no Mercado do Rio Vermelho, com o sol amanhecendo sobre o azul da Paciência. O velho e bom mercado, onde se come buchada, mocotó e xinxim de bofe sem fazer cara feia. Cerveja no copo de geleia, comida na travessa de barro, mesa de madeira sem toalha. Tudo muito à vontade. Se falta luxo, os preços se aproximam bastante dos cobrados nos grandes

8 Última dose de bebida alcoólica que se toma em uma festa ou bar antes da volta para casa. 
restaurantes. Uma moqueca de camarão, por exemplo, não sai por menos de CR\$ 7 mil e um prato de feijoada, por CR\$2,8 mil. ${ }^{9}$ A vantagem é o funcionamento ininterrupto 24 horas por dia. São 34 boxes para a venda de comida, bebida, artesanato e peixe. Apenas meia dúzia dos boxes são peixarias, que só funcionam pela manhã. (TUDO..., 1994, p. 4)

Ali, onde se come "sem fazer cara feia", marcando, em certa medida, a "ojeriza" ao popular que envolve, diga-se de passagem, todos os sentidos: a estética da comida popular - a cerveja no copo de geleia, a comida servida na travessa de barro, a mesa sem toalha - seus cheiros, os sabores, os temperos, aspectos que vão além da preparação e que compõem um verdadeiro mosaico icônico de representações do comer popular. O "velho e bom mercado", ambiente de informalidade, em permanente ausência de serviços públicos básicos, passa a ser, naquele momento, enquadrado em uma fase denominada como de "decadência”.

Tal cenário de abandono já se encontrava instalado, inclusive despertando o desejo de alguns comerciantes de que o espaço passasse para o domínio privado, em contraponto à ausência do poder público. Tal como pode ser observado nesta matéria jornalística em tom de denúncia sobre tal estado:

O antigo mercado de peixe do Rio Vermelho, está abandonado pela prefeitura e já apresenta sinais de decadência, além de deficiências na rede de esgoto sanitário. Apesar de vender pescado e outros alimentos, a higiene inexiste e os quatro sanitários públicos (femininos e masculinos) estão com vazamentos, transformando-se num foco de mau cheiro. Os comerciantes queixam-se das taxas que pagam, culpam a prefeitura pelo estado crítico e querem que o mercado seja privatizado. O processo de degradação do mercado começou há muito tempo. Os quatro sanitários públicos construídos na área externa não foram reformados, a maioria das portas não fecha, oferecendo cenas degradantes. As águas fétidas dos sanitários escorrem para o calçadão. $\mathrm{O}$ amplo calçamento de pedras portuguesas está totalmente esburacado e cheio de água estagnada. A rede de águas

9 Na data da reportagem, o salário mínimo possuía o valor de CR\$ 42.829,00. Disponível em: http://www.oabsp.org.br/subs/saoluizdoparaitinga/noticias/valores-do-salario-minimo-nacional-desde-sua. 
pluviais está entupida, represando as águas de lavagem de vísceras de peixes e outros alimentos. O que era para ser um local limpo virou área de risco para os feirantes e consumidores. (MENDONÇA, 2000, p. 4)

Alguns investimentos pontuais são realizados a fim de manter o seu posto de "maior reduto da boemia baiana" (SANTOS, 2003), ainda marcado por sua frequência variada, trilha sonora também eclética e a presença de pratos populares da culinária baiana, como o sarapatel e o arrumadinho.

O resultado de tal processo é uma dinâmica "gangorra" de investimento e desinvestimento ao longo do tempo e no espaço, em um processo contínuo de desenvolvimento geográfico desigual. (HARVEY, 1973, 1982, 2003; SMITH, 1982, 1984) Lees (2008) nos chama ainda a atenção ao fato de que o capitalismo está sempre criando novos lugares, novos ambientes projetados para lucro e acumulação, no processo de desvalorização de investimentos e paisagens anteriores.

O ponto é que o processo que culmina em uma "decadência" espacial não é um fenômeno inocente, tampouco surge apenas do desinteresse particular de antigos frequentadores. É importante frisar que tal fenômeno está intimamente ligado a um desinvestimento, que chamo de proposital, em que narrativas de declínio e morte têm sido ultrapassadas por um discurso neoliberal de regeneração e renascença. (DAVIDSON; LEES, 2005)

A globalização espelha e espalha tais iniciativas e traz consigo signos que sustentam o moderno como algo homogeneizado, passível de reprodução e, portanto, pertencente ao mundo, retirando cada traço de identidade local, ou melhor, os ressignificando:

A reforma do Mercado do Peixe, que será reinaugurado sexta-feira, custou cerca de R 3 milhões. [...] A obra é fruto de uma Parceria Público Privada (PPP) feita entre a prefeitura e o Grupo Schincariol, que garantiu, assim, o direito de ser a única marca de cerveja vendida no espaço nos próximos dez anos. [...] O design da estrutura, feito pela Fundação Mário Leal Ferreira, é bem parecido com o dos bares que estão à beira do Lago Paranoá, em Brasília, e no Porto Madero, em Buenos Aires, na Argentina. (BRITO, 2010, p. 12) 
A reforma, que além da pretensão de trazer ares modernos e um caráter global, baseia-se em um discurso de higiene de caráter individualista e liberal. O discurso ideológico, promovido pelo poder público em torno da cidade moderna e civilizada, gira em torno do desejo de transformar a barroca Salvador em uma metrópole global.

De maneira geral, tal conjunto de práticas e experiências é direcionado para camadas populares da população, segundo características sociais e culturais dominantes, além do que um dos desdobramentos dessa linha de pensamento leva ao funcionamento de um código moral que responsabiliza os indivíduos pela adoção e insistência em certos padrões de comportamento, preconizando mudanças desses padrões.

Nesta esteira, o horário de funcionamento do Mercado foi modificado, assim como as práticas de limpeza e o preparo de refeições readaptado e, em um primeiro momento, notou-se uma mudança de público:

O primeiro sábado de funcionamento do Mercado do Rio Vermelho, conhecido popularmente como Mercado do Peixe, foi marcado pelo sol e pela ocupação de várias mesas por clientes antes das 10 horas, numa situação muito diferente do que acontecia antes da revitalização da área, que foi inaugurada no último dia 10. [...] A gerente do Bar e Restaurante Travessia, Eleide São Pedro Teles, que trabalha há 13 anos no Mercado do Peixe, explicou que o movimento da última sexta-feira foi muito bom. A gerente do Beleza Rara, Itamara Nunes, explicou que a mudança do horário de funcionamento, que passou a ser das 8 [da manhã] às 4 horas [da tarde], permite que a limpeza e preparo dos alimentos sejam feitos de forma mais correta. Feliz, José Batista Junior, do Tô em Casa, diz que a frequência de clientes melhorou em quantidade e em qualidade. Ele disse que a reforma atraiu um público mais tranquilo ao contrário do ocorria até o final do ano passado. (MOURA, 2010, p. A10)

O trecho acima apresenta uma série de aspectos tomados como positivos pelos próprios feirantes, à época, incluindo que a "qualidade do público melhorou", o que revela um pensamento que leva em conta uma tendência de classificar os sujeitos sob o ponto de vista moral. Assim, podemos fazer uma analogia do termo "qualidade" e seu cunho classista com o termo "gente bonita", por sua vez, marcado pela identificação com 
valores de 'bom-gosto' e autodisciplina corporal, um habitus coincidente com alguns dos modelos representados para o "branco" jovem de classe média em Salvador (PINHO, 2005), já bastante difundido nas mais diversas conversas cotidianas e envolto numa dimensão racializada.

Essa possível "desordem" apresentada pelos textos jornalísticos costuma centrar-se em uma análise superficial e dual do fenômeno, culminando em um julgamento do que seria um espaço "bem" ou "mal" frequentado. Esse seria um julgamento questionável, ao passo que são baseados em códigos sociais de comportamento elaborados por valores de moralidade, como apontado anteriormente. Tais valores morais, legitimadores do modo de viver politicamente correto, são, por vezes, unifocais, perante uma realidade social multifacetada.

DaMatta (1987) chama de "gramática dos espaços" as implicações que os diversos espaços têm na forma de pensar e de comportar-se das pessoas. Segundo ele, a esses diversos espaços pertencem esferas de significação que delineiam uma visão de mundo e éticas particulares que constituem a própria realidade e ainda, portanto, normalizam e moralizam o comportamento a partir de perspectiva própria. Ou seja, os locais aqui possuem agência no pensar e no comportar dos sujeitos.

Partindo deste pressuposto, poder-se-ia imaginar uma "reestruturação" também do comportamento dos sujeitos. Todavia, um dos principais aspectos modificados relacionados com a reestruturação do espaço - o perfil dos frequentadores - não foi necessariamente substituído, tampouco alguns hábitos de limpeza e organização. Assim, tal reforma não conseguiu dar conta do projeto higienizador do espaço:

Reformado há 2 anos, Mercado do Peixe ainda sofre com sujeira. O anúncio de uma grande obra com direito a mirante, anfiteatro, reforma dos banheiros e dos boxes, melhorias na pavimentação e estacionamento prometiam salvar o reduto dos boêmios do Mercado do Peixe, no Rio Vermelho. No lugar dos boxes de alvenaria e toldos chegaram as lonas, o calçamento foi requalificado, os banheiros e a infraestrutura local melhoraram. Até aí, tudo bem, mas há um velho problema que não há reforma que resolva: a sujeira. 'É um povo muito mal-educado. As pessoas jogam 
copos de plástico no chão... E ainda tem o lixo jogado pelos ambulantes que passam por aqui', ressalta o diretor da Associação dos Permissionários do Mercado do Peixe, Antônio Nunes. O paulista, Roberto Perez, 56, está em Salvador a trabalho pela sexta vez e resolveu conhecer ontem o famoso Mercado do Peixe. Sofreu uma decepção. Sentar para comer, nem pensar. 'Achei muito feio e desorganizado. Não me parece muito higiênico'. (PEREZ, 2012, p. 22-23)

Santos (2012), no período de sua pesquisa no local, percebeu que o mesmo apresentava uma espécie de "segregação" espacial velada já que possuía dois ambientes distintos, que nomeou como "lado A" e "lado B". Para Mary Douglas (2014), as ideias sobre separar, purificar, demarcar e punir transgressões têm como sua função principal impor sistematização numa experiência inerentemente desordenada. Em relação à existência de dois lados, observa-se uma clara tentativa de distinguir os públicos frequentadores desse mesmo espaço, já que se percebeu um modus operandi diferenciado e também de investimento. $\mathrm{O}$ ciclo de desinvestimento é retomado, ao passo que se finda uma gestão municipal.

A demolição do então Mercado do Peixe cinco anos após a conclusão das obras de reestruturação foi parte das intervenções de Requalificação da Orla do Rio Vermelho. (OBRAS..., 2015) Para além disso, tais obras fazem parte de um projeto maior que abarca diferentes pontos estratégicos na capital baiana a fim de "revitalizá-los", marcando a não exclusividade do Mercado do Peixe em relação a tal processo, mas de toda a cidade, inclusive em bairros periféricos.

O projeto implementado pela gestão municipal sofreu diversas críticas por parte dos antigos frequentadores, comerciantes e da população em geral, já que não houve um prévio debate com a população em relação ao destino das obras e dos sujeitos envolvidos com o espaço, marcando um aspecto violento e não dialógico do processo de gentrificação, diversas vezes ocultado pela mídia.

Santos (2012) identificou que, na anterior reestruturação do Mercado do Peixe, houve a demolição da estrutura antiga e a construção de um novo prédio com algumas características do antigo, como a 
distribuição dos boxes em dois lados, mas com novos detalhes também. No caso da reforma atual, a estrutura física do Mercado não foi reaproveitada e, no local, foi construído um ambiente com características totalmente novas ao que era antes, inclusive criando um novo nome e marca ao espaço, atualmente chamado de Vila Caramuru. Essa foi uma clara tentativa de não apenas criar uma nova urbanística e estética ao ambiente, mas de um movimento de construção de uma nova identidade.

$\mathrm{Na}$ época da inauguração da Vila Caramuru, o então secretário municipal de Cultura e Turismo de Salvador, Érico Mendonça, disse que o "espaço foi valorizado". (PACHECO, 2016) Entretanto, comerciantes antigos, como no caso da operadora Juliana Almeida, que comandava o Auge da Baiana, casa especializada em comida caseira, no entanto, preferia manter a tradição, dizendo: "Minha mãe começou como garçonete há 22 anos e, depois, conseguiu o próprio negócio. Oferecemos feijoada, mocotó, rabada, moqueca de peixe e maniçoba. Tudo o que era muito procurado antes". (SANTOS, 2016)

Por outro lado, há espaço para opiniões divergentes com a possibilidade de abertura de um espaço encarado como mais "diverso":

A diversidade dos produtos oferecidos na Vila Caramuru foi apontada pelos operadores de alguns dos quiosques como um diferencial que deve atrair o público. Eles acreditam que, com um cardápio mais variado, a procura deve aumentar. 'Salvador ganhou muito com uma área gourmet, com restaurantes para todos os gostos. Aqui as pessoas podem encontrar casas especializadas em caranguejo, lambreta, moqueca, feijoada, rabada e outras comidas nordestinas, além de comida italiana, carnes, sanduíches e picolés', contou o operador do Caranguejo do Pipa, Fábio Lacerda. (SANTOS, 2016)

Segundo Henández e Arnáiz (2005), nos contextos urbanos, parece que o comensal contemporâneo se converteu em um indivíduo muito mais autônomo em suas escolhas. Soma-se a isso o desejo de ampliação do espaço de tomada de decisão alimentar. Não se trata, portanto, de homogeneizar o comensal contemporâneo, mas sim de contextualizá-lo em um ambiente de moldagem social. 
Para Hall (2002), ao discutir a homogeneização cultural e global, há uma fascinação pela diferença e com a mercantilização da etnia e da alteridade. E como impacto do global, há um novo interesse sobre o local. Dessa maneira, cabe que, ao invés de pensar o global como substituto do local, seria mais prudente pensar em uma articulação entre ambos.

É na Vila Caramuru que a gourmetização, aspecto importante do processo de gentrificação em contextos comensais, aparece. O leque de opções de refeições populares não dá mais conta dos desejos da nova clientela, então ao cardápio são adicionados desde "revisitações" de pratos da culinária baiana até sorvetes e pratos da culinária italiana.

Assim, ainda que pese no discurso midiático a suposta demanda por "diversidade", o antigo Mercado do Peixe e hoje Vila Caramuru é o espaço onde o global e o regional, o tradicional e o moderno, a cidade colonial-barroca e a moderno-capitalista se estreitam e se inter-relacionam, ao passo que esses movimentos estão forjados na lógica da disputa, no embate cotidiano e no ciclo de investimento-desinvestimento pautado pelo capital.

\section{CONSIDERAÇÕES FINAIS}

Diante do conteúdo abordado, pode-se concluir que o processo de gentrificação e higienização de espaços comensais, tal qual o Mercado do Peixe, revelam-se estreitamente ligados ao discurso que é produzido pelo poder público, mídia e também pelo senso comum. Foi possível perceber o uso de adjetivos polidos e educados e termos otimistas como "revitalização", "reestruturação" e "requalificação", dentre outros eufemismos em referência ao processo de gentrificação. Isso dilui seu caráter homogeneizador, fragmentado, hierarquizado e muitas vezes violento, evitando educadamente a constituição de classe dos processos envolvidos. É possível ainda que, a própria população em geral também assuma tais discursos, ainda que sempre caibam discursos divergentes.

Tais iniciativas, portanto, tornam-se questionáveis, à medida que são descartadas as vias dialógicas e consensuais, pois são realizadas 
verticalmente pelo poder público, sem levar em os sujeitos que ali frequentavam, os aspectos particulares de suas práticas alimentares, além da dinâmica e estética espaciais.

No caso, o Mercado do Peixe foi totalmente modificado em sua estrutura física, que em nada - ou pouco - lembra o antigo espaço no que tange a esse aspecto, e passa a adotar - ao menos pelos veículos de comunicação - outro nome, em uma tentativa de promovê-lo como novo espaço. Soma-se a tal contexto a utilização de estratégias que afastam o público anterior, como: modificação do horário de funcionamento, uso de segurança particular e de hostess (recepcionistas), elevação dos preços das refeições e "gourmetização" das mesmas.

De maneira geral, constata-se que o fenômeno da gentrificação corrobora com o modelo caótico e predatório de cidade e que, consequentemente, o processo de urbanização em espaços comensais, marcado pelo esteticismo espetacular e pela dinâmica do capital, marca um aprofundamento de desigualdades sociais, econômicas e culturais em tais contextos.

\section{REFERÊNCIAS}

AMADO, J. Bahia de todos os santos: guia de ruas e mistérios. Rio de Janeiro: Record, 1991.

ARAUJO, J. M. O. Bahia: negra, mas limpinha. 2006. Dissertação (Mestrado em Ciências Sociais) - Faculdade de Filosofia e Ciências Humanas, Universidade Federal da Bahia, Salvador, 2006.

BRÁS, J. G. V. A higiene e o governo das almas: o despertar de uma nova relação. Revista Lusófona de Educação, Lisboa, v. 12, p. 113-138, 2008.

BRITO, J. Reforma de Mercado custou R 3 milhões. Correio, Salvador, Caderno Mais, p. 12, 8 set. 2010.

CALABRESE, F. Estudos de requalificação e valorização urbana e paisagística do Rio Vermelho em Salvador. 2013. Dissertação (Mestrado Profissional em Conservação e Restauração de Monumentos e Núcleos Históricos) Faculdade de Arquitetura, Universidade Federal da Bahia, Salvador, 2013. 
CERTEAU, M. A invenção do cotidiano: morar, cozinhar. Petrópolis: Vozes, 1994.

DAMATTA, R. A casa e a rua: espaço, cidadania, mulher e morte no Brasil. Rio de Janeiro: Guanabara, 1987.

DAMATTA, R. Carnavais, malandros e heróis: para uma sociologia do dilema brasileiro. Rio de Janeiro: Rocco, 1997.

DAVIDSON, M.; LEES, L. New-build "gentrification" and London's riverside renaissance. Environment and Planning A: Economy and Space, Thousand Oaks, v. 37, n. 7, Jul. 2005.

DOUGLAS, M. Pureza e perigo. São Paulo: Perspectiva, 2014.

FERREIRA FILHO, A. H. Desafricanizar as ruas: elites letradas, mulheres pobres e cultura popular em Salvador (1890-1937). Afro-Ásia, Salvador, n. 21-22. p. 238-256, 1998.

GLASS, R. Introduction: Aspects of change. In: CENTRE FOR URBAN STUDIES (ed.). London: aspects of change. London: MacKibbon and Kee, 1964.

HALL, S. Who needs identity? In: HALL, S.; GAY, P. Questions of cultural identity. London: New York: Sage, 2002.

HARVEY, D. The limits to capital. Chicago: University of Chicago Press, 1982.

HARVEY, D. The New Imperialism. Oxford: Oxford University Press, 2003.

HARVEY, D. Social justice and the city. London: Edward Arnold, 1973.

HERNÁNDEZ, J. C.; ARNÁIZ, M. G. Alimentación y cultura: perspectivas antropológicas. Barcelona: Ariel, 2005.

JACQUES, P. B. Elogio aos errantes. Salvador: EDUFBA, 2012.

LARGO da Mariquita, no Rio Vermelho, em pleno abandono. A Tarde, Salvador, p. 6, 6 março 1976.

LEES, L.; SLATER, T.; WYLY, E. Gentrification. New York: Routledge, 2008.

MENDONÇA, J. Fase de decadência atinge Mercado do Rio Vermelho. A Tarde, Salvador, ano 87, 9 ago. 2000. p. 4. Caderno 1.

MIGUEZ, P. C.; LOIOLA, E. A economia do carnaval da Bahia. Bahia Análise \& Dados, Salvador, v. 21, n. 2, p. 285-299, abr./jun. 2011. 
MOURA, M. Mercado do Peixe tem sábado animado. A Tarde, Salvador, p. A10, 19 set. 2010.

OBRAS de requalificação do Rio Vermelho serão realizadas em três etapas. Correio, Salvador, 22 abr. 2015. Disponível em: http://www.correio24horas. com.br/noticia/nid/obras-de-requalificacao-do-rio-vermelho-seraorealizadas-em-tres-etapas/. Acesso em: nov. 2017.

PACHECO, C. Novo Mercado do Peixe reabre essa semana com 11 novos restaurantes. Correio, Salvador, 20 mar. 2016. Disponível em: https://www. correio24horas.com.br/noticia/nid/novo-mercado-do-peixe-reabre-essasemana-com-11-novos-restaurantes/. Acesso em: nov. 2017.

PEREZ, F. É preciso cuidar também. Correio, Salvador, p. 22-23, 10 maio 2012.

PINHO, O. A. Etnografias do Brau: corpo, masculinidade e raça na reafricanização em Salvador. Estudos Feministas, Florianópolis, v. 13, n. 1, p. 127-145, jan./abr. 2005.

QUIRINO, M. A Bahia de outrora. Salvador: Livraria Progresso, 1946.

RISÉRIO, A. Uma história da cidade da Bahia. Rio de Janeiro: Versal, 2004.

SANTOS, G. Mercado do Peixe. A Tarde, Salvador, 22 jan. 2003.

SANTOS, G. Quiosques da Praça Caramurú lotam na volta do tradicional espaço. Correio, Salvador, 2 abr. 2016. Disponível em: https://www. correio24horas.com.br/noticia/nid/quiosques-da-praca-caramuru-lotamna-volta-do-tradicional-espaco/. Acesso em: nov. 2017.

SANTOS, L. A. S. O corpo, o comer e a comida: um estudo sobre as práticas corporais e alimentares no mundo contemporâneo. Salvador: Edufba, 2008.

SANTOS, L. L. O comer no mercado: a comensalidade baiana no contexto da "revitalização" do Mercado do Peixe, Salvador, Bahia. 2012. Dissertação (Mestrado em Alimentos, Nutrição e Saúde) - Escola de Nutrição, Universidade Federal da Bahia, Salvador, 2012.

SILVA, C. L. A cidade do Salvador nos seus 454 anos. Salvador: EGBA, 2006.

SMITH, N. Gentrification and uneven development. Economic Geography, Abingdon, v. 58, n. 2, p. 139-155, Apr. 1982.

SMITH, N. Uneven development: nature, capital, and the production of space. Oxford: Blackwell, 1984. 
TUDO termina nas mesas do Mercado. A Tarde, Salvador, p. 4, 20 mar. 1994.

VAN WEESEP, J. Gentrification as a research frontier. Progress in Human Geography, Thousand Oaks, v. 18, n. 1, p. 74-83, 1994. 


\section{Corpo, identidade, cultura e risco reflexões sobre o excesso de peso em contexto urbano ${ }^{1}$}

TATIANA COURA OLIVEIRA, DINA CZERESNIA E ELIANE PORTES VARGAS

\section{INTRODUÇÃO}

Este trabalho problematiza a relação entre excesso de peso e construção da identidade em mulheres de camadas populares em um contexto urbano específico, a cidade do Rio de Janeiro. No entanto, o material

1 As reflexões aqui apresentadas consistem em desdobramento da pesquisa "Concepções e práticas alimentares e corporais de mulheres com excesso de peso", apresentada em 2016 ao Programa de Pós-Graduação em Epidemiologia em Saúde Pública da Escola Nacional de Saúde Pública Sergio Arouca - Fundação Oswaldo Cruz, portanto apoiam-se nos mesmos referenciais teórico-metodológicos acrescidos de outros. Alguns resultados da pesquisa já foram discutidos no artigo "Concepções sobre práticas alimentares em mulheres de camadas populares no Rio de Janeiro, RJ, Brasil: transformações e ressignificações”. Entretanto, a realização do trabalho de campo realizado em um bairro de uma cidade do Rio de Janeiro produziu reflexões adicionais sobre o viver na cidade que puderam ser aqui exploradas adicionalmente. 
aqui analisado apresenta características observadas também em outros contextos urbanos. Parte-se de uma compreensão de cidade, para além de seu delineamento geográfico, como um lugar-espaço de realização de práticas de controle sobre o corpo, culturalmente conduzidas pela lógica de risco. As conexões entre obesidade e risco, e também o estigma, relacionam-se ao caráter individualista das prescrições que regem os discursos de prevenção e promoção da saúde alimentar. (CZERESNIA, 2004; OLIVEIRA; CZERESNIA; VARGAS, 2017) A disseminação das informações sobre o risco encontra-se amplificada nos grandes centros urbanos por meio de recursos tecnológicos que acirram contradições e retroalimentam o mercado de consumo e a oferta de serviços por expertises que as conformam. Nesta direção, o hiperpreventivismo, enquanto estratégia de controle dos possíveis males que podem acometer esse corpo-cidade, também intervém na produção da subjetividade. O excesso de peso se configura como uma pandemia contemporânea que atravessa as sociedades em termos globais, apesar de serem observadas características diferenciadas considerando-se idade, gênero, bem como relacionadas às condições de vida entre aqueles em situação de vulnerabilidade social. (SWINBURN et al., 2011)

Ressalta-se que as condições que conduzem ao crescimento nos índices epidemiológicos de sobrepeso e obesidade se realizam em meio a uma crescente valorização do corpo magro como padrão estético, num contexto evidente de lipofobia social. (FISCHLER, 1995) A realidade epidemiológica do excesso de peso se contrapõe à ascensão de um ideal estético oposto, revelando uma incongruência e uma dificuldade de adequação social a esse padrão normativo. O termo "normal" designa duplamente o que é ideal, o que é como deve ser; e o que ocorre na maior parte dos casos, ou que constitui a média de uma condição mensurável. (CANGUILHÉM, 2012) O acirramento dessa contradição entre as duas acepções do termo "normal" incita o agravamento de tensões: a obesidade promove insatisfação corporal e processos de estigmatização em diferentes níveis. (PARKER, 2012) Depressão, ansiedade, baixa autoestima, insatisfação corporal e pequena procura por cuidados de saúde são 
citados como efeitos adversos à estigmatização da obesidade. (PUHL; HEUER, 2010)

Historicamente, a intensificação do valor estético atribuído à magreza se dá a partir da segunda metade do século XX, produzindo sentidos sociais desqualificadores para a gordura corporal: o corpo contemporâneo se transformou progressivamente em referencial para a construção das identidades pessoais, nas quais atributos físicos determinam e marcam a definição de um lugar no mundo. Uma série de atributos morais positivos, como fertilidade, força e atratividade, anteriormente associados à gordura corporal foi substituída por imagens negativas. (VARTANIAN; SILVERSTEIN, 2013) Essas transformações não ficaram confinadas a áreas geográficas específicas, mas repercutiram de maneira global. Para Hall (1997), o encurtamento da relação tempo-espaço, favorecido pelas atuais tecnologias de comunicação, propiciou o enredamento da sociedade contemporânea, em complexas redes de significados em detrimento destas se situarem em fusos horários diferenciados ou delimitados territorialmente a partir de certa concepção de cidade.

Ademais, ainda que as cidades se caracterizem por diferentes histórias e estágios de desenvolvimento, bem como distintos modos e estilos de vida, o "viver na cidade" constitui parte e expressão de fenômenos complexos como as relações de identidade, etnicidade, territorialidade, globalização, lugares, fronteiras, situações às margens etc. (AGIER, 2011) Segundo o autor, trata-se de conceber a cidade como processo e observá-la em meio a dinâmicas relacionais configuradas por diferentes saberes, espaços e situações, sendo pertinente analisá-las na construção do conhecimento sobre as cidades e os contextos urbanos. Nessa perspectiva, transformações globais mais amplas da cultura impactam o "local e o cotidiano", ressignificando modos de viver e sentidos atribuídos às experiências locais, de todo modo cultural.

Beleza e aceitação social, como valores positivos do mundo contemporâneo que se ligam diretamente aos hábitos de vida relacionados à alimentação e à aparência corporal, se tornaram dimensões de grande repercussão na subjetividade e na vida cotidiana. (GIDDENS, 1991) 
Tais dimensões atravessam o tempo e o espaço para além daquele geograficamente delimitado. Nestes termos, Hall (1997) aponta a centralidade da cultura e suas dimensões globais como constitutiva em todos os aspectos da vida social na segunda metade do século XX.

Percebe-se claramente nesta passagem as transformações no modo de vida das pessoas comuns - transformações ocorridas nas culturas da vida cotidiana: o declínio do trabalho na indústria e o crescimento dos serviços e outros tipos de ocupação, com seus diversos estilos de vida, motivações, ciclos vitais, ritmos, riscos e recompensas; o aumento dos períodos de folga e o relativo vazio do chamado 'lazer'; o declínio das perspectivas de 'carreira' e dos empregos vitalícios dando lugar ao que tem sido chamado de 'flexibilidade no emprego', mas que, frequentemente, constitui uma questão de desemprego não planejado; as mudanças no tamanho das famílias, nos padrões de diferenças de geração, de responsabilidade e autoridade dos pais; o declínio do casamento numa época de incremento do divórcio, o aumento de famílias uniparentais e a diversificação de arranjos familiares; o envelhecimento da população, com seus dilemas acerca de uma terceira idade mais longa sem a ajuda do cônjuge, sustentada por generosos programas nacionais de seguros, sistemas públicos de saúde e outros sistemas de benefícios estatais; a redução das tradicionais idas à igreja e da autoridade dos padrões morais e sociais tradicionais e das sanções sobre as condutas dos jovens; os conflitos de gerações em consequência da divergência entre jovens e adultos, entre o declínio da ética puritana, de um lado, e o crescimento de uma ética consumista hedonista, de outro. Tais mudanças são relacionadas, de alguma forma, a situações sociais, de classe e geográficas: e não exclusivamente de classe. (HALL, 1997, p. 21-22)

Em se tratando de excesso de peso, podemos pensar, apoiados no autor, nos poderes determinantes de controle reincidente e sobreposto à cultura no que tange às imagens do corpo e de construção da subjetividade que circulam na cena urbana. (HALL, 1997) O modelo cultural predominante de "corpo aceito" socialmente foi legitimado pelo discurso biomédico e potencializado pela associação do excesso de peso a agravos à saúde, produzindo repercussões sobre os sentidos ligados ao corpo, independente de classe ou grupo social, porém com efeitos mais perversos sobre as mulheres. (BREWIS; HRUSCHKA; WUTICH, 2011; DEVAUX; SASSI, 2013) O aumento nos indicadores globais de 
excesso de peso levanta a necessidade de reflexões sobre questões mais amplas que se ligam às práticas alimentares em seu contexto micro e macrossocial, cujas transformações não se restringem à ampliação do acesso à informação nutricional ou orientação prescritiva em saúde. (STUCKLER; NESTLE, 2012)

Pressionados por normas provenientes do discurso médico, por padrões estéticos idealizados e delimitados por condições materiais de existência que moldam o consumo permeado por imposições da indústria de alimentos e da produção agrícola, diferentes grupos socioculturais são universalmente afetados pelo excesso de peso, porém de modos e com consequências muito distintas. Nesse cenário, há um predomínio de abordagens parciais de enfrentamento ao excesso de peso que, no âmbito da saúde, são pautadas na recomendação de práticas alimentares "saudáveis" com forte presença de um discurso que superestima o papel da gestão individual (CASTIEL; MORAES; PAULA, 2016), adicionado de uma proliferação, em diferentes instâncias, de orientações alimentares baseadas em perspectivas contraditórias que semeiam divergências, além de produzirem informações controversas. (RODGERS, 2016) A divulgação do discurso do risco com fins de promoção da saúde se confunde com a de recomendações voltadas predominantemente a um padrão estético.

\section{PERSPECTIVAS TEÓRICO-METODOLÓGICAS, O CAMPO E O UNIVERSO DA PESQUISA}

Mediante a natureza complexa do problema e sua expresssão em contextos específicos, esta pesquisa buscou problematizar a relação entre excesso de peso e construção da identidade em mulheres de camadas populares em um contexto urbano. A designação "camadas populares" ou "classes populares" assumida na pesquisa apoia-se na vertente de tradição antropológica que designa determinados seguimentos sociais em contexto urbano no Brasil como "classes trabalhadoras". (DUARTE, 1988) Não corresponde, portanto, a uma definição do grupo do estudo exclusivamente por critérios de classificação de renda, mas a um gradiente mais 
amplo de características que comporta as dimensões simbólicas e culturais delimitadoras de determinados grupos sociais, sobretudo aqueles que são parte de sociedades complexas, como a sociedade contemporânea, constituídas de amplos processos, como o da globalização.

A estratégia adotada considerou a importância de se incluir o ponto de vista das mulheres entrevistadas, ou seja, de valorizar a perspectiva de quem vive a experiência que está sendo apresentada na interação com o pesquisador. Esse recurso foi fundamental para relativizar a especificidade do olhar de profissional nutricionista da pesquisadora principal, considerando que a produção do dado não está isolada do sujeito que realiza a pesquisa. (PEIRANO, 2014) Esses sentidos foram interpretados em articulação com aspectos macrossociais que contextualizam a questão em relação às dimensões culturais como estigma e risco a partir dos discursos sociais produzidos sobre a obesidade.

O trabalho foi desenvolvido a partir de uma perspectiva etnográfica, entendendo o método como uma forma de nos aproximarmos da realidade das pessoas, valorizando a compreensão do caráter multidimensional do fenômeno em sua manifestação social e cultural, bem como a captação dos sentidos da experiência vivida e singularidade do indivíduo. (PEIRANO, 1995) Assim como a aproximação do pesquisador em relação ao fenômeno que se pretende compreender, tal processo só é possível a partir da compreensão de que a teoria é indissociável da prática. (VICTORA; KNAUTH; HASSEN, 2000)

Conformada pela atenção constante sobre o que e como ocorre, considerando que a observação empírica afeta o campo e a vida social, percebe-se a impossibilidade de se isolar a produção do conhecimento do sujeito que a produziu. $\mathrm{O}$ campo, portanto, ofereceu informações que se transformaram após processo reflexivo, sendo precedido por uma etapa de reconhecimento do território e das diferentes condições de vida e acesso locais. (DAMATTA, 1978)

Partimos da compreensão de que a saúde e seus sentidos são produzidos nos espaços da vida nos quais as pessoas estabelecem conexões. $\mathrm{O}$ indivíduo, a formação do seu corpo e da própria imagem corporal se 
realizam mediante trocas desde as mais básicas e cotidianas, simultaneamente físicas, orgânicas, simbólicas, culturais. (CZERESNIA; MACIEL; MALAGÓN, 2013) Cientes da indissociabilidade entre indivíduo e ambiente, optamos por apresentar características do universo do estudo e do campo da pesquisa, denominado no contexto da saúde como território de Manguinhos, como parte da produção de seus resultados. Nosso intuito é contribuir para uma compreensão ampliada dos elementos em jogo no controle do peso e práticas alimentares no campo da saúde e, em especial, no campo da alimentação e nutrição, refletindo em como esses aspectos podem contribuir na produção de iniquidades sociais.

Manguinhos compreende um conjunto de comunidades com especificidades internas singulares, cujas origens, trajetórias e processos de construções sociais foram configurados historicamente em estreita relação com determinantes políticos, econômicos e sociais. (FERNANDES; COSTA, 2013) Localizado geograficamente entre a Avenida Brasil, a Linha Amarela, a Avenida dos Democráticos e a Avenida Dom Elder Câmara, antiga Avenida Suburbana, Manguinhos é dividida internamente em: Parque Carlos Chagas (PCC), Parque João Goulart (PJG), Parque Oswaldo Cruz/Morro do Amorim (POC), Comunidade Samora Machel (CSM), Comunidade Nelson Mandela (CNM), Comunidade Mandela de Pedra (CMP), Comunidade Agrícola de Higienópolis (CAH); Conjunto Habitacional Provisório 2 (CHP2), Vila São Pedro (VSP), Vila Turismo (VT), Vila União (VU), Embratel, Comunidade Vitória de Manguinhos (CVM) e Condomínio Departamento de Suprimentos do Exército (DSUP). Manguinhos está entre as cinco piores situações, considerando o Índice de Desenvolvimento Humano (IDH) ${ }^{2}$ do Rio de Janeiro, junto com Guaratiba, Rocinha, Jacarezinho, Maré e Complexo do Alemão.

2 O IDH avalia as condições de vida de uma população a partir de três dimensões principais: educação, renda e saúde. O IDH educação incorpora ainda dois indicadores: a taxa de alfabetização e a taxa bruta de frequência à escola. $\mathrm{O} I \mathrm{DH}$ renda inclui apenas o indicador da renda per capita. O IDH saúde inclui a esperança de vida ao nascer e expressa o patamar de desenvolvimento humano de diferentes regiões e países. 
A região é marcada pela precariedade habitacional, insuficiência de serviços públicos e graves problemas ambientais que influenciam de forma importante a qualidade de vida de seus moradores e compõem o mosaico de desigualdades sociais que expressa a cidade do Rio de Janeiro. (FERNANDES; COSTA, 2013) Em 2007, as Secretarias Municipais de Saúde e Educação contabilizam uma população de 45 mil habitantes no território de Manguinhos, população que correspondia a 0,74\% de um total de 6.093.47 de habitantes da cidade do Rio de Janeiro. (CUKIERMAN; TEIXEIRA, 2008)

O Centro de Saúde Escola Germano Sinval Faria (CSEGSF) foi escolhido como local principal de coleta de dados por duas razões: (1) este Centro se constitui em uma referência de atendimento à saúde; (2) razões de segurança relacionadas ao avanço da violência nesse território, mediante o agravamento da crise econômica e sociopolítica no país. A entrada no campo foi facilitada pela equipe de Nutrição do Centro de Saúde e responsáveis administrativos do serviço. ${ }^{3}$ As vivências sociais em territórios tais quais Manguinhos são atravessadas pelas contradições inscritas no próprio espaço urbano. Elas produzem subjetividades originárias de uma sociabilidade ambígua nos indivíduos, pois se o território é, de um lado, fonte de toda sorte de violência e justamente por isso "prospera" na exata medida da falta dos direitos civis, por outro, se revela ali uma dimensão que o protege das forças do mercado, ao mesmo tempo em que o priva da "cidade", oferecendo-lhe alguma forma de acesso à comunidade. (BURGOS, 2002)

Desenvolvido entre os meses de setembro e novembro de 2015, o trabalho de campo considerou as seguintes etapas: (1) realização de observação dos atendimentos ambulatoriais de nutrição, dos encontros de um grupo de apoio multidisciplinar a usuários do serviço que apresentavam excesso de peso e de visitas domiciliares realizadas por uma agente de saúde no território; e (2) entrevistas semiestruturadas com as

3 Pesquisa aprovada pelo Comitê de Ética em Pesquisa da Escola Nacional de Saúde Pública Sergio Arouca (ENSP)/Fundação Oswaldo Cruz (Fiocruz), sob o parecer de número 1.138.011. 
usuárias do serviço de saúde. A observação e as entrevistas foram realizadas mediante utilização de roteiros previamente elaborados, sendo o último composto por dois blocos temáticos: práticas alimentares e corpo/alimentação. No primeiro, foi abordada a rotina de alimentação das informantes, na qual foram produzidas informações acerca das práticas, costumes e critérios eleitos no âmbito da escolha alimentar. No segundo, foram tratadas questões ligadas ao corpo e alimentação, considerando as perspectivas biomédica, cultural e de gênero.

Buscou-se, desse modo, estabelecer conexões entre as unidades de sentido identificadas e a literatura. $\mathrm{O}$ início da conversa sempre partia de uma narrativa ligada à vida da informante, relacionada às vivências pessoais. A pergunta "me conta, quem é você? o que faz?" dava início ao processo, que era direcionado de acordo com as questões que compunham o roteiro. (FRASER; GONDIM, 2004) Após a etapa de observação, os convites para participação no estudo foram dirigidos às usuárias do serviço que apresentavam excesso de peso, sendo essa identificação realizada visualmente em um primeiro momento. Tendo em vista a natureza qualitativa do estudo, tentou-se evitar constrangimentos ou barreiras que pudessem dificultar a abertura de um canal dialógico adequado. Neste sentido, a aferição do peso e da altura para o cálculo do Índice de Massa Corporal $\left(\mathrm{IMC}=\mathrm{kg} / \mathrm{m}^{2}\right)$ era realizada ao final da entrevista. Considerou-se, na avaliação, o sistema de classificação sugerido pela WHO (1995) que estratifica o excesso de peso em "obesidade" para aquele indivíduo que possuir um IMC maior ou igual a $30 \mathrm{~kg} / \mathrm{m}^{2}$ e em "sobrepeso" para aqueles com IMC entre 25 e 29,9 kg/m².

Ao todo, foram entrevistadas 21 mulheres, cujas características principais estão descritas a posteriori para uma melhor contextualização sociocultural do grupo. Todas são usuárias do CSEGSF. Em relação ao diagnóstico nutricional, dentre as 21 informantes, 18 possuíam obesidade em seus diferentes níveis: grau I ( $\mathrm{n}=8)$, grau II $(\mathrm{n}=5)$ e grau III $(n=5)$, estando as demais $(n=3)$ em situação de sobrepeso. Com idades compreendidas entre 23 e 64 anos, parte das informantes era proveniente da zona rural nordestina $(\mathrm{n}=5)$ ou zona rural do Espírito Santo $(\mathrm{n}=1)$, ou ainda do interior do Rio de Janeiro $(\mathrm{n}=1)$, cujas histórias 
singulares de migração aconteceram como tentativas de melhores condições de vida; as demais $(\mathrm{n}=14)$ haviam nascido na própria comunidade ou periferia urbana do Rio de Janeiro, sendo possível encontrar alguns relatos de migração dos pais $(\mathrm{n}=2)$ ou avós paternos ou maternos $(\mathrm{n}=3)$ vindos, em sua maioria, do interior de outros estados brasileiros.

Quanto à escolaridade, apesar de estarem majoritariamente inseridas em ocupações com menor exigência escolar, há um predomínio de mulheres com ensino médio completo $(n=10)$, seguido de ensino fundamental $(n=7)$ e ensino superior $(n=3)$, completo ou incompleto. Apenas uma das informantes relatou nunca ter frequentado uma escola, apesar de não ser analfabeta. Nos arranjos familiares, houve um predomínio do tipo mulher e cônjuge com filhos, sendo mais frequente a união consensual com início na juventude. Havia ainda duas entrevistadas solteiras com filhos, uma viúva e uma com o marido no cárcere.

Em relação à ocupação, 13 entrevistadas trabalhavam no setor formal em atividades como limpeza e serviços gerais $(n=6)$, serviços de saúde $(n=4)$, cozinheira $(n=1)$, auxiliar de escritório $(n=1)$, técnica em enfermagem $(n=1)$. Entre aquelas ligadas ao setor informal de trabalho, três exerciam serviços de limpeza em domicílios, uma era manicure e uma catadora de material reciclável. Havia duas pensionistas do Instituto Nacional do Seguro Social (INSS) - uma por tempo de contribuição; outra por viuvez - e uma desempregada. O salário dessas mulheres era a única fonte de renda para uma considerável parte das famílias ( $n=9$ ), sendo também importante na complementação financeira das demais $(n=12)$.

Atividades de seleção e de preparo dos alimentos eram de responsabilidade das entrevistadas, sendo realizadas nos intervalos entre uma ou outra atividade doméstica. Na maioria dos casos, as compras de gêneros alimentícios eram feitas em hipermercados localizados em bairros adjacentes ao território, ficando itens perecíveis, como hortifrutigranjeiros ou produtos cárneos, para serem adquiridos em Manguinhos, quando possível. 


\section{AS ENTREVISTADAS, UM POUCO ALÉM DO IMC}

E1 [Nordestina de Pernambuco, 45 anos, IMC $37,8 \mathrm{~kg} / \mathrm{m}^{2}$ ]

E1 migra aos 14 anos para o Rio de Janeiro com uma promessa de emprego. Ao chegar, descobre que havia sido trazida para prostituição. Foge pouco tempo depois do local onde estava e passa a trabalhar como empregada doméstica. Casou-se posteriormente, mas a relação mantinha um caráter violento: "Escrava de marido: lavando, passando, cozinhando, arrumando e apanhando... Lavando, passando, cozinhando, arrumando $e$ apanhando. Porque ele me batia muito". Sabe ler e escrever, mas não foi alfabetizada institucionalmente. Vive atualmente com um segundo companheiro em um apartamento na comunidade do Mandela com o auxílio do Programa Aluguel Social, do Rio de Janeiro. Trabalha como cozinheira em um restaurante comercial no centro do Rio. E1 é hipertensa.

E2 [Nordestina da Paraíba, 47 anos, IMC $55,55 \mathrm{~kg} / \mathrm{m}^{2}$ ]

Filha de um agricultor e uma professora, trabalhava de dia em sua cidade e fazia graduação em Pedagogia à noite em Campina Grande. Casou-se aos 24 anos com um rapaz que, apesar de paraibano, residia e trabalhava no Rio de Janeiro: "Quando eu vim pra cá, a gente foi morar na Ilha. Lá na praia da rosa [...] nunca tinha visto favela na minha vida. Mas aí o tempo foi passando e eu fui me acostumando". Separou-se do marido por causa do seu alcoolismo. Hoje, trabalha como auxiliar em um escritório de contabilidade em Caxias e vive com os dois filhos em Manguinhos. É hipertensa e diabética.

E3 [Nordestina do Rio Grande do Norte, 43 anos, IMC 37,66 kg/m²]

Chegou ao Rio de Janeiro com 25 anos para perpetuar uma relação amorosa extraconjugal que havia começado em sua cidade natal. Grávida, ficou hospedada com um irmão na comunidade do Jacaré. Sobre sua vida no Rio Grande do Norte: “Assim, eu... Meu marido [o primeiro] tinha mais condições que meu pai. E ele bancava... Eu tinha vida de 
princesa em casa [...]. Depois que eu vim pra cá pro Rio éque a coisa pegou! Trabalhar, tomar conta de casa... De marido... Eu falava assim: eu quero voltar pro Norte!". Atualmente, mora na comunidade do Mandela em casa própria, com o segundo marido e dois filhos desta relação. Trabalha como diarista em Bonsucesso. Já fez consulta com uma nutricionista com vistas à perda de peso.

E4 [Curicia/RJ, 56 anos, IMC 30,82 kg/m²]

Passou a primeira infância com sua madrinha no estado do Rio de Janeiro porque a mãe realizava tratamento para tuberculose em Minas Gerais. É separada, possui dois filhos de dois relacionamentos anteriores. Trabalha desde os 14 anos e há 21 anos presta serviço na área de limpeza nas dependências da Fiocruz. Reside na comunidade do Amorim, em imóvel que é herança paterna. Já fez consulta com uma nutricionista, mas não faz nenhum acompanhamento para perda de peso no momento.

E5 [Rio de Janeiro/RJ, 28 anos, IMC 25,1 kg/m²]

Trabalha como auxiliar de serviços gerais, residindo atualmente no DSUP com os três filhos. Seu marido está no cárcere. Informante mais fechada, falou pouco durante a entrevista, sempre com respostas rápidas e curtas. E5 nunca consultou uma nutricionista.

E6 [Capixaba/ES, 64 anos, IMC 29,77 kg/m²]

Migrou com a família para o Rio aos 13 anos, é a mais velha entre as irmãs de um total de dez irmãos. Vindos do Espírito Santo, fugiram de uma situação de miséria e fome. Sempre atuou no setor informal, a princípio como empregada doméstica e, mais recentemente, como diarista. Chama a atenção sua preocupação com o peso. Já fez consulta de nutrição.

E7 [Duque de Caxias/RJ, 30 anos, IMC 30,13 kg/m²]

É técnica em Enfermagem e está cursando graduação na área. E7 relata uma infância difícil: "Minha infância foi um pouco triste. Um pouco triste porque [...] eu passei muita necessidade. [...] Eu já fiquei na porta de 
padaria pedindo pão". Acabou de pedir demissão em um hipermercado - trabalhava como caixa - para assumir um emprego como técnica em hemodiálise numa clínica especializada. Possui carro e casa própria no Amorim. Nunca fez consulta com nutricionista, mas acompanha dois dos seus três filhos por apresentarem hiperglicemia e hipercolesterolemia.

E8 [Carioca, Rio de Janeiro, 36 anos, IMC $25,91 \mathrm{~kg} / \mathrm{m}^{2}$ ]

Relata ter tido uma infância difícil, inclusive com falta de alimentos em casa, situação que piorou após a morte do pai. Retomou os estudos após o nascimento da segunda filha - na época da entrevista, com três anos - e sonha em fazer Psicologia. E8 trabalha como agente comunitária no CSEGSF, mora com o companheiro e com a filha mais nova na comunidade agrícola de Higienópolis.

E9 [Carioca, Rio de Janeiro, 51 anos, IMC 35,58 kg/m²]

Trabalha em empresa terceirizada na Fiocruz prestando serviço de limpeza. Tem o ensino médio completo, é casada há 28 anos e tem dois filhos. Teve uma infância tranquila, segundo conta. Nunca fez consulta nutricional, entretanto já procurou endocrinologista para perda de peso.

E10 [Carioca, Rio de Janeiro, 29 anos, IMC 30,89 kg/m²]

É casada, mas não tem filhos. Apesar de estar desempregada, possui curso técnico em Administração. Já consultou nutricionista e endocrinologista para perda de peso, mas, em seu relato, disse preferir atendimento do médico ao nutricional. Segundo relato, "era bem magrinha... que sempre vivia muito doente e depois foi me dando vitamina, ficava muito internada. Depois fui engordando... [...]. Eu era bastante forte mesmo, mais forte que eu sou hoje".

E11 [Nordestina da Paraíba, 33 anos, IMC $33,33 \mathrm{~kg} / \mathrm{m}^{2}$ ]

Veio para o Rio procurando condições melhores de vida. Ficou hospedada com um tio em Campo Grande/RJ, mas logo foi trabalhar como doméstica, residindo no local de trabalho. Vive em Manguinhos 
desde que trouxe a mãe e a irmã da Paraíba. É casada e tem um filho de 12 anos. Possui ensino médio completo, mas trabalha como faxineira. Já consultou endocrinologista para perda de peso. Apesar de nunca ter ido a um nutricionista, acompanha seu filho, que apresenta excesso de peso, hipercolesterolemia e hiperglicemia nos atendimentos de nutrição.

E12 [Carioca, nascida e criada na Favela do João/RJ, 31 anos, IMC $\left.32,20 \mathrm{~kg} / \mathrm{m}^{2}\right]$

Mora na CMP em uma situação de extrema vulnerabilidade social. Sabe ler, escrever e gosta de frequentar a biblioteca Parque de Manguinhos. Saiu de casa grávida do primeiro filho e foi morar com o companheiro. O segundo filho do casal é criado pela avó materna, que mora em Sepetiba/RJ. E12 é catadora de material reciclável, mas não considera isso um trabalho. Seu marido é responsável pelo transporte e venda do material coletado. Está tentando perder peso e já fez atendimento nutricional.

\section{E13 [Nordestina da Bahia, 54 anos, IMC $66,83 \mathrm{~kg} / \mathrm{m}^{2}$ ]}

Migrou para o Rio de Janeiro aos 17 anos na busca de uma vida melhor. Instalou-se com um tio na comunidade do Jacaré e começou a trabalhar em uma indústria de produtos químicos na própria região. E13 é casada e tem um único filho. Apresenta obesidade severa há muitos anos e desde sempre luta contra a situação. Sua narrativa é marcada por momentos de choro e frustação, mas também pela alegria de estar viva.

\section{E14 [Carioca, Rio de Janeiro, 42 anos, IMC 40,83 kg/m²]}

Possui distrofia progressiva, uma má formação genética que limita a locomoção. Passou parte da infância com a avó e, após o falecimento dela, ficou com tios em Duque de Caxias, vindo para Manguinhos logo depois. Casou aos 19 anos e, após o nascimento de sua segunda filha, percebeu a necessidade de voltar a estudar. E14 se divorciou aos 38 anos e vive na CSM com três filhas e uma neta. Tem o ensino médio completo 
e trabalha com agente no projeto Teias-Manguinhos. Nunca procurou ajuda para perder peso.

E15 [Carioca, nascida e criada em Manguinhos/RJ, 29 anos, IMC $\left.57,7 \mathrm{~kg} / \mathrm{m}^{2}\right]$

É filha de pai piauiense e mãe paraibana, casada e mãe de um filho. E15 possui ensino médio completo e é manicure em um salão de beleza em Manguinhos. Possui uma relação difícil com a mãe, que, em seu relato, apresentava-se desde a infância extremamente controladora da sua alimentação. Iniciou ganho de peso entre 15 e 16 anos. Já procurou clínico geral e nutricionistas para perder peso, já foi atendida também no Centro de Referência de Obesidade (CRO) na Penha e tem novo encaminhamento para o serviço.

E16 [Carioca, nasceu e cresceu em São Cristóvão/RJ, 35 anos, IMC $\left.35,53 \mathrm{~kg} / \mathrm{m}^{2}\right]$

E16 mora atualmente em Manguinhos com dois filhos. Está desempregada há sete meses e vive da pensão de morte do pai de seus filhos. Considera ter tido uma boa infância. Fez sua primeira consulta de nutrição na semana em que fizemos a entrevista.

E17 [Carioca, nascida e criada no Amorim/RJ, 28 anos, IMC 30 kg/ $\left.\mathrm{m}^{2}\right]$

Casada, sem filhos, trabalha como agente comunitária no centro de saúde, apesar da formação como técnica em Enfermagem e mais recentemente como nutricionista, graduação realizada em uma instituição de ensino superior privada instalada em Bonsucesso. Morou por um ano em Caxias e há duas semanas retornou ao Amorim. Muito tranquila e comunicativa, não expressou a presença de limitações financeiras severas na infância, mas relatou história paterna de alcoolismo. Desde a adolescência, enfrenta problemas com o peso. 
E18 [Carioca, nascida e criada no Amorim/RJ, 48 anos, IMC 41,64 $\left.\mathrm{kg} / \mathrm{m}^{2}\right]$

Filha de pai português e mãe nordestina, é auxiliar de serviços gerais na Fiocruz. É separada, cuida de uma sobrinha de sete anos e tem uma filha de 23 anos, que mora na Penha. Nunca procurou nutricionista ou endocrinologista para perder peso.

\section{E19 [Carioca/RJ, 33 anos, IMC 33,78 kg/m²]}

É casada há quase 20 anos e tem dois filhos: um rapaz de 17 e uma menina de 10 anos. Suas memórias indicam uma infância difícil, pois a mãe era a única responsável por oito filhos e três sobrinhos abandonados pela irmã. E19 trabalha como auxiliar de serviços gerais e possui casa própria na comunidade de Manguinhos. Está tentando perder peso, tendo iniciado atividade física em academia particular no mês anterior à entrevista. E19 nunca fez uma consulta de nutrição.

\section{E20 [Carioca/RJ, 23 anos, IMC 35,33 kg/m²]}

Possui o ensino médio completo, mora de aluguel na comunidade de Manguinhos com os filhos, a mãe, um irmão e dois sobrinhos. Um dos filhos participa do programa de desnutridos do CSEGSF, de onde recebe uma cesta básica/mês. Apesar de acompanhar o filho no atendimento do programa, nunca fez uma consulta nutricional.

\section{E21 [Carioca/RJ, 57 anos, IMC 28,5 kg/m²]}

Solteira, E21 mora com a filha única em casa própria na comunidade de VU. Apresenta um histórico de inúmeras interrupções na vida escolar, conseguindo se formar em magistério no começo da década de 1980. Nunca conseguiu se colocar na profissão, tendo atuando como catadora de material reciclável e como empregada doméstica para se sustentar. Formou-se posteriormente como técnica em Enfermagem, profissão que exerce no CSEGSF. Demonstra grande preocupação com a alimentação e com o corpo. 


\section{TEMPO, MEMÓRIA, SUBJETIVIDADE E COMER NA CIDADE}

Em relação à dieta, é difícil cuidar... É difícil cuidar, porque eu não tenho muito tempo pra fazer a dieta, também não tenho [faz um gesto discreto com a mão esquerda, esfregando o indicador e o polegar], porque dieta é caro. É caro, num é barato. (E2, 47 anos, IMC $55,55 \mathrm{~kg} / \mathrm{m}^{2}$ )

O relativamente recente e acelerado processo de urbanização brasileira está articulado a um conjunto de mudanças socioeconômicas e políticas que precisam ser consideradas na compreensão dos processos ligados às transformações, permanências e incorporações das práticas alimentares. O lócus privilegiado de atividade econômica nas cidades brasileiras fez com que estas se tornassem difusoras de novos padrões sociais, que incluem, dentre outros aspectos, o consumo alimentar. (BRITO, 2006)

Ocorrida a partir da segunda metade do século xx, a urbanização obteve seu auge entre os anos de 1950 e 1970, fomentando também o processo migratório. Esse movimento precisa ser levado em consideração para se compreender como a reestruturação das relações dos territórios com a cidade impactou não somente no padrão de sociabilidade anteriormente existente, fomentando um processo de integração social pautado em impessoalidade e formação de frágeis identidades coletivas territoriais, mas também em novas formas de consumo. (BURGOS, 2005)

Conformada pela forma hegemônica contemporânea de produção e distribuição de alimentos, a migração campo-cidade favorece um processo de transição no padrão alimentar dos indivíduos. De modo geral, podem ser considerados três desdobramentos possíveis no processo de transição do padrão alimentar: o primeiro relacionado à presença de uma dicotomia na qual novas possibilidades são adotadas, ainda que as antigas sejam adaptadas; o segundo apresenta maior indefinição e menor autonomia com significativo risco de desequilíbrio alimentar; enquanto o terceiro é caracterizado por uma desestruturação dos elementos de origem sem que se reconstrua organizadamente um novo padrão alimentar, possibilidade esta ligada a uma desvinculação sociocultural e à vulnerabilidade econômica. (CALVO, 1982) 
Embora aparentemente simples, as escolhas alimentares são comportamentos complexos e determinados por muitos fatores e interações. Nesse sentido, para uma melhor compreensão dos achados da investigação, os resultados foram articulados a partir das transformações nas práticas alimentares das informantes decorrentes de um processo de migração e consolidação da vida na periferia urbana, passando pela experimentação corporal do excesso de peso e contradições dos sentidos atribuídos ao binômio saúde/estética; considerando-se o predomínio, no campo da saúde, de um discurso que culpa o indivíduo pelo próprio excesso de peso. (CASTIEL; MORAES; PAULA, 2016)

As percepções das informantes sobre as práticas alimentares, tanto as atuais quanto as da infância, expressam sentidos socialmente atribuídos e localizados na memória. Nas narrativas das entrevistadas, é possível, por exemplo, perceber o quanto as memórias relacionadas à alimentação no passado são experiências presentes na elaboração de uma nova prática alimentar. Marcadas por crenças, tabus, cerimônias e distinções, as práticas e sistemas alimentares revelam repetidamente a cultura em que cada um está inserido. (MACIEL, 2001) As atitudes relacionadas à comida são normalmente apreendidas precocemente e conferem ao comportamento um poder sentimental duradouro.

Apesar da adaptação humana a uma variedade de possibilidades alimentares, a seleção do que comer está para além de questões básicas de subsistência e de manutenção da vida. Ela é baseada em escolhas que perpassam tanto questões culturais, como tradições e tabus, quanto por situações geopolíticas, como urbanização e distanciamento da produção agrícola, bem como econômicas, sendo estas socialmente compartilhadas. Nesse sentido, considerando as variações do tempo e da memória das entrevistadas, duas formas de consumo alimentar emergem nas narrativas: uma ligada ao manejo da terra presente entre as migrantes e outra marcadamente agroindustrial, articulada aos modos de vida na periferia urbana. Cabe considerar que tais modelos são aqui considerados de modo não excludentes, sendo apresentados separadamente apenas para efeito de análise. As memórias que, independentemente da localização geográfica, apontavam escassez 
alimentar, pobreza e miséria ligavam-se simbolicamente a uma determinada forma de comer como apontam os depoimentos abaixo:

A gente comia era inhame de porco... Era banana verde. [...] A gente cozinhava pros bichos e tirava para nós... (E6, 64 anos, IMC $29,77 \mathrm{~kg} / \mathrm{m}^{2}$, migrante da zona rural)

Meu tio trouxe estas coisas da xepa [...] Aí meu primo fez esta sopa de entulho pra gente comer até que minha mãe voltasse. (E8, 36 anos, IMC 25,91 kg/m², nascida na zona urbana)

Castro (2005) chama os alimentos resistentes à seca que não fazem parte da refeição cotidiana de sertanejos, mas que são decisivos para a manutenção da vida em momentos de extrema vulnerabilidade social de "iguaria bárbara". Comer "inhame de porco" ou "sopa de entulho" era uma estratégia de sobrevivência utilizada em momentos críticos, cujo peso simbólico ainda está presente na memória das entrevistadas. Para DaMatta (1986), alimento é tudo aquilo que supre as necessidades de nutrientes e assim corrobora para a manutenção biológica da vida, mas para ser comida é preciso estar atrelado a determinadas representações sociais e culturais. Feijão, por exemplo, é comida; sendo importante marcador da identidade alimentar das entrevistadas. Apesar de os relatos evidenciarem em grande medida uma condição de não satisfação das necessidades básicas, a ausência do feijão no prato era expressão da própria fome. O termo "mistura" também aparece nas narrativas e remete a um grupo de preparações que complementavam a refeição. Segundo Zaluar (1994), “mistura” engloba preparações a base de ovos, carnes e/ou vegetais.

Os aspectos e códigos que determinam um valor simbólico para o “comer" também abrem espaço para a compreensão de como ocorre a ressignificação de antigas práticas frente às novas demandas da vida em um ambiente de periferia marcado por desigualdade, vulnerabilidade e insegurança alimentar. Esse processo pode ser explicado a partir da perspectiva de habitus definida por Bourdieu (1983, p. 65) como "um sistema de disposições duráveis e transponíveis que, integrando todas as experiências passadas, funciona a cada momento como uma matriz de percepções, 
de apreciações e de ações". A noção de habitus pode favorecer uma reflexão sobre como condicionamentos sociais exteriores ou mesmo a própria subjetividade dos sujeitos, coexistem numa intensa relação de interdependência, expressando o diálogo e a troca constante e recíproca entre as distintas instâncias socializadoras. (BOURDIEU, 1983) Nessa direção, o conceito fornece o caminho para a compreensão de como uma matriz cultural é permeável a transformações advindas, por exemplo, do modo de vida urbano no qual condutas sociais delineiam-se por conformações mais individualistas e articuladas a um ritmo de vida marcado pela escassez de tempo. (DIEZ GARCIA, 2003) No presente, chama a atenção o quanto os produtos ultraprocessados foram incorporados às práticas alimentares das entrevistadas. Antes vistos como supérfluos (ZALUAR, 1994), são agora considerados básicos na alimentação.

O tipo de acesso, os constrangimentos financeiros e as contradições ligadas ao consumo de alimentos industrializados expressam ainda classificações e modos de distinção relacionados ao discurso contemporâneo da alimentação saudável: "Final de semana é o dia do lixo na janta. Da pizza, da lasanha, do industrializado. Lasanha de caixinha, cachorro quente, refrigerante". (E8, 36 anos, IMC 25,91 kg/m²) É importante ressaltar que o "comer" assume posição central no aprendizado social, sendo o comportamento relativo à comida ligado diretamente ao sentido que as pessoas atribuem a si mesmas e à sua própria identidade social.

Nesse sentido, questionamos: qual o sentido atribuído a si mesmo ao se considerar que se come lixo? A presença de sistemas simbólicos ligados ao comer implicam representações e imaginários sociais que envolvem escolhas e classificações nas quais a presença de códigos atua no estabelecimento de relações dos homens entre si e com o ambiente onde estão inseridos. (CANESQUI, 2005) Esse menor valor atribuído por E8 aos ultraprocessados está articulado ao discurso da saúde. Entretanto, conhecê-lo e repeti-lo não são suficientes para uma mudança na prática alimentar; pelo contrário, tais produtos parecem ser apreciados. Um determinado "gosto" pelo industrializado se associa numa perspectiva bourdiesiana a um gosto de classe. (BOURDIEU, 1983) 
Existem particularidades nas possibilidades de acesso e peculiaridades nas formas de consumo entre os diferentes grupos sociais para os quais o mercado se adequa. Grupos sociais economicamente desfavorecidos são mais constrangidos ao consumo de alimentos baratos, práticos e palatáveis que, no entanto, apresentam aditivos químicos, açúcar e sódio em excesso. (CANELLA et al., 2014) Essa realidade se confronta com discurso contemporâneo da saúde, que, ao fomentar uma demanda de consumo de produtos considerados benéficos, exige das informantes constantes ressignificações em relação ao "comer", as quais oscilam entre o prazer e a culpa. (OLIVEIRA et al., 2017) O depoimento de uma entrevistada é ilustrativo:

Pelo que eu vejo na televisão, olha que você tem que comer comida saudável, salada, aquilo outro... Agora, botô queijo no meio... [suspira]. E eu sei que é ruim. Eu como com pão, com macarrão, com miojo... Vai dizer que isso é bom? Claro que não, eu não sou burra. Que uma comida que fica pronta com 3 minutos, vai dizer que ela é saudável? Ela não é! Não é... De jeito nenhum. [...] E a gente sabe que se alimenta mal, sabe que se alimenta mal, mas... (E1, 45 anos, IMC $37,8 \mathrm{~kg} / \mathrm{m}^{2}$ )

Aspectos da singularidade individual, mesmo em contexto de vulnerabilidade social, assinalam diferenças nas formas de lidar e driblar ou não constrangimentos de natureza econômica, cultural e pessoal que se ligam às práticas alimentares reconhecidas como promotoras do excesso de peso. Uma das narrativas, por exemplo, expressa a preocupação de uma entrevistada com a alimentação:

Se eu vejo que aquilo não tá surtindo efeito, eu mudo pra outra coisa, não fico insistindo. Por exemplo, o que me ajudou a baixar o colesterol foi a farinha de berinjela, entendeu? [...] A quinoa comprei, mas não compro mais, porque acho que não é valido pelo preço, e também o outro faz o mesmo efeito. (E21, 57 anos, IMC $28,5 \mathrm{~kg} / \mathrm{m}^{2}$ )

Embora se caracterizem como grupo de baixa renda, os moradores de Manguinhos representam uma fatia do mercado consumidor para produtos considerados “saudáveis". Se, por um lado, os produtos e 
"fórmulas" veiculados nas mensagens se confrontam a constrangimentos financeiros próprios das camadas populares, por outro, movem-se no imaginário social dessas mesmas mulheres como alternativas possíveis para o alcance de sucesso em relação ao emagrecimento:

Eu tava de férias e aí andando por Bonsucesso, a menina me deu um papelzinho. Aí foi, me convidou pra subir lá no prédio, pra conhecer... Eu disse: 'tô com pressa' e ela 'não, não, mas vamos lá! Só 10 minutinhos!'. Eu fui. Chegando lá, ela já bateu o shake. Me perguntou o sabor que eu queria... Eu queria morango, adorava morango! Ela fez de morango. Bebi. Bebi o chá. Aí ela: 'Ó, vem amanhã pra gente tirar medida' e que num sei o que... Aí mostrou lá aquele tanto de coisa. [...] Em dois meses, eu perdi sete quilos. Só que é muito caro! (E3, 43 anos, IMC $\left.37,66 \mathrm{~kg} / \mathrm{m}^{2}\right)$

É importante atentar para a dimensão populacional da questão. Mulheres negras em condições de vida urbana, multíparas, com baixa escolaridade e renda têm, segundo Hoffmann (2012), maior probabilidade de apresentar obesidade. Independentemente da existência de predisposições genéticas, o rápido aumento da obesidade em populações geneticamente estáveis sugere a importância dos fatores socioambientais. (SWINBURN et al., 2015) Além da indústria e do comércio de alimentos, a tecnologia, o desenvolvimento urbano e sua interferência na vida cotidiana contribuem para a criação de ambientes obesogênicos, nos quais as mulheres de baixa renda configuram um grupo duplamente vulnerável. Ressalta-se, assim, a necessidade de debater as conexões entre cultura e excesso de peso e, particularmente, como o conceito de risco em sua configuração predominante, tende a reforçar estigmatização e culpa ao tratar problemas como a obesidade sob a égide da gestão individual.

\section{O DISCURSO DO RISCO, DA PROMOÇÃO DA SAÚDE E PRESCRIÇÕES DESCONTEXTUALIZADAS}

[...] Tão falando que o suco tá dando câncer [suco em pó]. Como éque eu vou fazer? Tem que ser da fruta então... Da fruta é melhor. Mas a fruta tá cara. Tem que ser do pozinho mesmo. (E12, 31 anos, IMC 32,2 kg/m²) 
O médico perguntou se eu tinha acesso à internet: 'ah você tem acesso a internet?'. Eu disse sim. Então tá bom... Ele disse: 'então abre lá e procura o que é diabetes, o que a diabetes faz'. E a gente vê... Eu tenho consciência de tudo, só que a gente pula certas partes. (E2, 47 anos, IMC $55,55 \mathrm{~kg} / \mathrm{m}^{2}$ )

A gestão de riscos é um dos eixos do discurso da promoção da saúde, que, por sua vez, enfatiza a autonomia dos sujeitos e dos grupos sociais como ponto de partida para uma reorientação estratégica em saúde. Os estudos de risco conferem cientificidade às recomendações que se disseminam em várias instâncias da vida social, exercendo poder de orientar, aconselhar e regular interferindo de forma intensa nas escolhas pessoais do cotidiano. (CZERESNIA, 2004) No caso do excesso de peso, uma série de controles e prescrições de autocuidado alimentares está ligada ao discurso do risco. (CASTIEL; FERREIRA; MORAES, 2014) Essas orientações envolvem, de modo geral, propostas de redução na ingestão de produtos densamente calóricos e aumento do consumo daqueles ricos em vitaminas, minerais e fibras. (KRAEMER et al., 2014)

A análise do risco epidemiológico apresenta uma lógica que isola fatores de exposição e avalia sua probabilidade de associação a agravos em saúde, buscando inferir a causalidade desses eventos. (AYRES, 2002) É importante destacar que a identificação de fatores de riscos contribuiu significativamente para o desenvolvimento da epidemiologia na conformação que a disciplina assumiu na confluência com outras formas de avaliação de risco por distintas áreas de conhecimento. Entretanto, o caráter analítico do conceito dificulta a contextualização dos processos epidemiológicos mais complexos tal qual o excesso de peso contemporâneo e, consequentemente, o estabelecimento de articulações mais amplas, fundamentais para sua compreensão. (CZERESNIA, 2004) Esse processo de redução, inerente à construção do modelo de análise do risco, acaba por se transportar à compreensão dos fenômenos estudados e isto é feito de uma forma que materializa modos de entender, construir tecnologias e administrar recursos para resolver os problemas de saúde.

O discurso profissional que orienta o autocuidado transmite preceitos, na maior parte dos casos, sem atentar para como estes podem 
ser adotados com efeito no cotidiano dos indivíduos. (OLIVEIRA et al., 2017) Associada aos limites econômicos, bem como a desejos ligados à própria cultura, evidencia-se uma dificuldade de adequação aos padrões dietéticos prescritos em dissociação com a realidade vivida, como nos aponta E10 (29 anos, IMC $30,89 \mathrm{~kg} / \mathrm{m}^{2}$ ), quando nos relata sua experiência de atendimento em saúde: “[...] na nutricionista, é sempre: não pode comer, não pode comer". Essas recomendações de autocuidado são quase sempre distanciadas da realidade cultural e financeira das entrevistadas, não se sustentando por muito tempo no cotidiano das mesmas. Nessa direção, é possível dizer que as orientações sob a regra do risco estão voltadas a uma lógica externa e defensiva, que dificulta a criação de alternativas afirmativas nos contextos reais. No caso do excesso de peso, principalmente da obesidade, resoluções restritivas realizadas sem uma sustentação que possibilite a efetivação de mudanças nas práticas alimentares podem acarretar sofrimento ao indivíduo.

Eu me pego comendo as coisas escondido... Assim... Comendo uma coisa assim [simula o corpo encolhido, olhando pros lados]. Gente, eu tô na minha casa! Por que é que eu tô comendo escondido? [...] Eu sinto que isso me atrapalhou muito! Eu só não sei como lidar com isso. (E15, 29 anos, IMC 57,7 kg/m²)

Acontece que intervenções prescritivas em geral deixam de considerar questões de caráter amplo como as condições de vida e de trabalho nas cidades e, particularmente, das formas de produção e distribuição alimentar que determinam efetivamente as opções de consumo possíveis nas periferias urbanas:

[...] com dieta, tem que comprar o filezinho todo dia, que é caro... As verduras, que tem que comprar todo dia, que tá muito caro; e assim, outras coisas mais. Arroz integral, pão integral... [...]. E assim, acaba que fica muito difícil, porque hoje você começa uma coisa, mas amanhã tu não tem mais dinheiro. Aí tu começa a furar... Fica cheio de buraco. E tu acaba abrindo mão. (E2, 47 anos, IMC $55,55 \mathrm{~kg} / \mathrm{m}^{2}$ )

É nesse contexto que a propagação de prescrições descontextualizadas da realidade das pessoas promove uma perda de referências 
alimentares, conforme indica Fischler (1979) ao trabalhar o conceito de gastro-anomia. Para ele, a grande quantidade de informações não só sobre o quê comer, mas como e quando fazê-lo disponíveis na atualidade promovem ansiedade e medo nas pessoas. Muitas vezes contraditórias, essas informações não esclarecem; pelo contrário, terminam por promover insegurança em relação às escolhas alimentares. É o caso das entrevistadas E4 ( 56 anos, IMC 30,82 kg/m²) e E6 (64 anos, IMC 29,77 $\mathrm{kg} / \mathrm{m}^{2}$ ), que mudaram a prática de comer arroz e feijão por compreenderem que esses alimentos "engordam".

Nessa direção, a lógica do risco exerce pressão sobre a carga de responsabilidade individual, associando-se a outros múltiplos discursos em relação à alimentação que mais confundem do que informam. As abordagens partem da perspectiva de que a posse de informações seria suficiente para a realização de boas escolhas alimentares, enfatizando-se a responsabilidade individual na gestão de hábitos e práticas. Entretanto, a posse de informação por si só não é suficiente para garantir um consumo alimentar seguro, nem torna mais fácil aderir a um determinado "estilo de vida".

A escolha do produto a ser consumido é de cada um, mas condicionantes mais amplos interferem na margem de liberdade das opções individuais, moldando possibilidades e induzindo comportamentos e hábitos. (CASTRO, 2015) Questões como prazer, convívio, tradições culturais, gosto, preço, praticidade e palatabilidade determinam o consumo alimentar de forma desigual. É necessário compreender mais amplamente as diferentes lógicas implicadas nessas escolhas, dentre as opções disponíveis.

A partir da idealização de um sujeito autônomo, capaz de estabelecer relações de custo/benefício em suas ações diárias, o discurso do risco culpabiliza aqueles que não conseguem se adequar. E13 (54 anos, IMC $66,83 \mathrm{~kg} / \mathrm{m}^{2}$ ) sente culpa e exemplifica com a orientação recebida de comer maçã quando tiver vontade de comer torresmo, sob a alegação de que o segundo alimento "faz mal” para sua saúde. Afirma não entender porque não estudou e, apesar de considerar não ter a "mente aberta pra certas coisas", E13 pensa muito sobre "o que comer" e argumenta que, se 
está com vontade de comer o torresmo, então vai comer porque, se não consegue emagrecer, não faz sentido não comer.

A racionalidade das escolhas efetivamente exercidas nem sempre corresponde às preconizadas pelos estudos de risco que orientam as práticas dos profissionais de saúde. Portanto, a margem da "livre escolha" se conforma de acordo com possibilidades e constrangimentos que se configuram em uma rede de processos mais amplos que se sobrepõe ao indivíduo. Essa mesma informante (E13), em diálogo com uma médica de Del Castilho, um bairro da Zona Norte do Rio de Janeiro, de quem ela gosta ("ela é tão boa comigo"), se diz cansada e que às vezes percebe "uma confusão na minha cabeça e eu me perco... Aí eu choro, fico triste".

Prescrições moralistas e normativas dificilmente dão lugar à compreensão dos significados que se ligam ao corpo e à própria alimentação, enquanto prática socialmente compartilhada, conectada à sociabilidade e prazer. Recomendações alimentares realizadas por profissionais se confundem com as veiculadas na mídia, estando associadas a um amplo mercado de consumo no qual uma série de programas e produtos "milagrosos" é comercializada com a promessa da conquista de uma boa forma. Destacam-se medicamentos anorexígenos ou disabsortivos, cirurgias, implantes, fórmulas, alimentos funcionais, shakes, dietas e programas especiais de atividade física.

A reflexividade presente no campo da nutrição se associa à polifonia dos discursos que se ligam à alimentação, tais quais o da saúde, da gastronomia e da beleza, amplificando a angústia da escolha e promovendo vulnerabilidade às estratégias de marketing que se vinculam à comercialização de produtos que supostamente são benéficos para a saúde. (PINTO et al., 2017) A narrativa de E15 expressa a maior exposição de determinados grupos ao consumo de serviços e atendimentos em saúde de procedência duvidosa:

Fui para num médico lá em Caxias, que está até preso [...]. Ai ele passou uma fórmula pra mim, cara à beça! Quase 200 reais. Eu tinha até visão com aquilo ali. [...] Não tinha fome, não comia... Depois, tinha um pozinho que botava embaixo da língua, aquilo me deixava leve... Mas tudo eu mandei fazer na farmácia de manipulação: tudo ótimo! [...] quando eu parei de tomar, engordei o dobro. (E15, 29 anos, IMC $57,7 \mathrm{~kg} / \mathrm{m}^{2}$ ) 
Santos (2008) coloca o quanto as preocupações com a alimentação e o corpo têm se colocado como uma questão central no cotidiano das pessoas. Em estudo realizado na cidade de Salvador, aponta-se a percepção de "corpo não saudável", o "medo de morrer" e a preocupação estética alinhada às tentativas de mudanças entre seus entrevistados. A ideia do "cuidado de si", também presente entre os entrevistados de Santos (2008), reforça a ligação entre o discurso do risco e a culpabilização dos sujeitos. A crença de que a obesidade é uma condição autoinfligida nos permite estabelecer uma relação entre obesidade, estigma e risco. (GRACIA-ARNAIZ, 2010; PINTO; BOSI, 2010)

Os discursos de promoção da saúde, ao ressaltarem a responsabilidade individual na gestão de hábitos e comportamentos amparados no conceito de risco, além de terem pouca eficácia, colaboram com a formação e perpetuação desse problema de saúde alimentar em grande medida estigmatizante. (BREWIS, 2014; LINK; PHELAN, 2014) As informações sobre o risco acirram contradições, participando de um ciclo que retroalimenta o problema e incorpora o mercado de consumo para recursos tecnológicos e expertises, que se conformam reflexivamente a partir das necessidades criadas em meio ao avanço do conhecimento científico.

\section{CONSIDERAÇÕES FINAIS}

No presente trabalho, buscamos problematizar a relação entre excesso de peso e construção da identidade em mulheres de camadas populares em um contexto urbano específico na cidade do Rio de Janeiro. Partindo de uma compreensão de cidade como um lugar-espaço de realização de práticas de controle sobre o corpo, abordamos as conexões entre obesidade, risco e estigma como relacionadas ao caráter individualista das prescrições presentes nos discursos da promoção da saúde alimentar. As questões trazidas à tona pelas narrativas das entrevistadas evidenciam uma dupla vulnerabilidade das mulheres de camadas populares. Se, por um lado, as práticas alimentares desse grupo são conformadas por escassez de tempo e recursos materiais escassos, mas fomentado 
pelo exacerbado consumo alimentos industrializados, o discurso do risco presente no modelo de enfrentamento do sobrepeso/obesidade resulta em atribuição de culpa na medida em que desconsidera as questões macro e microssociais implicadas no fenômeno.

As narrativas das entrevistadas evidenciam uma ressignificação do habitus alimentar, que, por um lado, absorve discursos sobre o que seria uma alimentação saudável e, por outro, se realiza de acordo com disponibilidades concretas de vida. Os sentidos atribuídos ao corpo sofrem influência tanto pela disseminação midiática de um padrão de beleza idealizado, quanto pelo discurso do risco que associa o excesso de peso a agravos à saúde. Esse processo fomenta a estigmatização dessas mulheres em meio de dimensões sobrepostas: a gordura associada à aparência do corpo, a pobreza como expressão da classe e o gênero ligado ao feminino. Outra questão que se apresenta é a inviabilidade de consolidação das recomendações de saúde alimentar pautadas num modelo prescritivo, que não considera questões relacionadas às condições materiais de existência. Aspectos da vida individual, cultural, social, econômica e de mercado precisam ser pensados de modo integrado na abordagem do excesso de peso e obesidade.

A compreensão da interface território, risco epidemiológico e estigma ao se pensar o excesso de peso possibilita a elaboração de estratégias de intervenção mais pertinentes. Se, por um lado, abordagens individuais podem vir a ser exercidas de modo mais coerente com as condições materiais e existenciais das pessoas em contextos urbanos, por outro, a presença de ações de regulação da indústria devem ser incrementadas. No caso da obesidade, assim como de outros problemas com características equivalentes, a colaboração entre diferentes atores e áreas de conhecimento é uma condição essencial para construir alternativas criativas e vem de modo ainda tímido, sendo trilhada. Isso deve ser tentado mesmo considerando a força de grandes corporações que colaboram para que as contradições entre padrões de beleza e a realidade dos modos de vida concretamente possíveis acentuem cada vez mais a ocorrência de obesidade e estigma, retroalimentando determinadas demandas de consumo. 


\section{REFERÊNCIAS}

AGIER, M. Antropologia da cidade: lugares, situações, movimentos.

São Paulo: Editora Terceiro Nome, 2011.

AYRES, J. R. C. M. Epidemiologia, promoção da saúde e o paradoxo do risco. Revista Brasileira de Epidemiologia, São Paulo, v. 5, p. 28-42, 2002. Suplemento 1.

BOURDIEU, P. Sociologia. Organizado por Renato Ortiz. São Paulo: Ática, 1983.

BREWIS, A. A. Stigma and the perpetuation of obesity. Social Science \& Medicine, Amsterdã, v. 118, p. 152-158, Oct. 2014.

BREWIS, A. A.; HRUSCHKA, D. J.; WUTICH, A. Vulnerability to fat-stigma in women's everyday relationships. Social Science \& Medicine, Amsterdã, v. 73, n. 4, p. 491-497, Aug. 2011.

BRITO, F. O deslocamento da população brasileira para as metrópoles. Estudos Avançados, São Paulo, v. 20, n. 57, p. 221-236, maio/ago. 2006.

BURGOS, M. B. Cidade, territórios e cidadania. Dados: Revista de Ciências Sociais, Rio de Janeiro, v. 48, n. 1, p. 189-222, 2005.

BURGOS, M. B. Favela, cidade e cidadania em Rio das Pedras. In: BURGOS, M. B. (org.). A utopia da comunidade: Rio das Pedras, uma favela carioca. Rio de Janeiro: Editora PUC-Rio: Loyola, 2002.

CALVO, M. Migration et alimentation. Social Science Information, Thousand Oaks, v. 21, n. 3, p. 383-446, 1982.

CANELLA, D. S. et al. Ultra-processed food products and obesity in Brazilian households (2008-2009). PLoS One, São Francisco, v. 9, n. 3, p. e92752, 2014.

CANESQUI, A. M. Mudanças e permanências da prática alimentar cotidiana de famílias de trabalhadores. In: CANESQUI, A. M.; DIEZ GARCIA, R. W. (org.). Antropologia e nutrição: um diálogo possível? Rio de Janeiro: Fiocruz, 2005.

CANGUILHÉM, G. O normal e o patológico. 7. ed. Rio de Janeiro: Forense Universitária, 2012. 
CASTIEL, L. D.; FERREIRA, M. S.; MORAES, D. R. Os riscos e a promoção do autocontrole na saúde alimentar: moralismo, biopolítica e crítica parresiasta. Ciência \& Saúde Coletiva, Rio de Janeiro, v. 19, n. 5, p. 1523-1532, maio 2014.

CASTIEL, L. D.; MORAES, D. R.; PAULA, I. J. Terapeuticalização e os dilemas preemptivistas na esfera da saúde pública individualizada. Saúde e Sociedade, São Paulo, v. 25, n. 1, p. 96-107, 2016.

CASTRO, I. R. R. Desafios e perspectivas para a promoção da alimentação adequada e saudável no Brasil. Cadernos de Saúde Pública, Rio de Janeiro, v. 31, n. 1, p. 7-9, jan. 2015.

CASTRO, J. Geografia da fome: o dilema brasileiro: pão ou aço. 5. ed. Rio de Janeiro: Civilização Brasileira, 2005.

CUKIERMAN, H. L.; TEIXEIRA, M. O. Cotidianos de Manguinhos. Sociologias, Porto Alegre, ano 10, n. 19, p. 92-105, jan./jun. 2008.

CZERESNIA, D. Ciência, técnica e cultura: relações entre risco e práticas de saúde. Cadernos de Saúde Pública, Rio de Janeiro, v. 20, n. 2, p. 447-455, 2004.

CZERESNIA, D.; MACIEL, E. M. G. S.; MALAGÓN OVIEDO, R. A.

Os sentidos da saúde e da doença. Rio de Janeiro: Editora Fiocruz, 2013.

DA MATTA, R. Ofício do etnólogo ou como ter anthropological blues. In: NUNES, E. O. (org.). A aventura sociológica: objetividade, paixão, improviso e método na pesquisa social. Rio de Janeiro: Zahar, 1978.

DAMATTA, R. O que faz o Brasil, Brasil? Rio de Janeiro: Rocco, 1986.

DEVAUX, M.; SASSI, F. Social inequalities in obesity and overweight in 11 OECD countries. European Journal Public Health, Oxônia, v. 23, n. 3, p. 464-469, Jun. 2013.

DIEZ GARCIA, R. W. Reflexos da globalização na cultura alimentar: considerações sobre as mudanças na alimentação urbana. Revista de Nutrição, Campinas, v. 16, n. 4, p. 483-492, 2003.

DUARTE, L. F. D. Da vida nervosa: nas classes trabalhadoras urbanas. 2. ed. Rio de Janeiro: Zahar, 1988.

FERNANDES, T. M.; COSTA, R. G.-R. As comunidades de Manguinhos na história das favelas no Rio de Janeiro. Revista Tempo, Rio de Janeiro, v. 19, n. 34, p. 117-133, jan./jun. 2013. 
FISCHLER, C. Gastro-nomie et gastro-anomie. Communications, Paris, v. 31, n. 1, p. 189-210, 1979.

FISCHLER, C. Obeso benigno, obeso maligno. In: SANT'ANNA, D. Políticas do corpo. São Paulo: Estação liberdade, 1995.

FRASER, M. T. D.; GONDIM, S. M. G. Da fala do outro ao texto negociado: discussões sobre a entrevista na pesquisa qualitativa. Paidéia, Ribeirão Preto, v. 14, n. 28, p. 139-152, 2004.

GIDDENS, A. As consequências da modernidade. São Paulo: Editora UNESP, 1991.

GOLDENBERG, M. Gênero, "o corpo" e "imitação prestigiosa" na cultura brasileira. Saúde e Sociedade, São Paulo, v. 20, n. 3, p. 543-553, 2011.

GRACIA-ARNAIZ, M. Fat bodies and thin bodies: cultural, biomedical and market discourses on obesity. Appetite, Amsterdã, v. 55, n. 2, p. 219-225, 2010.

HALL, S. A. Centralidade da cultura: notas sobre as revoluções culturais do nosso tempo. Educação e Realidade, Porto Alegre, v. 22, n. 2, p. 15-46, 1997.

HOFFMANN, R. Condicionantes do sobrepeso e da obesidade de adultos no Brasil, 2008-2009. Segurança Alimentar e Nutricional, Campinas, v. 19, n. 2, p. 1-16, 2012.

KRAEMER, F. B. et al. O discurso sobre a alimentação saudável como estratégia de biopoder. Physis: Revista de Saúde Coletiva, Rio de Janeiro, v. 24, n. 4, p. 1337-1360, 2014.

LINK, B. G.; PHELAN, J. Stigma power. Social Science \& Medicine, Amsterdã, v. 103, p. 24-32, Feb. 2014.

MACIEL, M. E. Cultura e alimentação ou o que têm a ver os macaquinhos de Koshima com Brillat-Savarin? Horizontes Antropológicos, Porto Alegre, v. 7, n. 16, p. 145-156, dez. 2001.

OLIVEIRA, T. C.; CZERESNIA, D.; VARGAS, E. P. "Eu tenho que me reeducar": discursos normativos e práticas alimentares relacionadas à perda de peso em mulheres de camadas populares. Demetra, Rio de Janeiro, v. 12, n. 3, p. 523-538, 2017.

OLIVEIRA, T. C. et al. Concepções sobre práticas alimentares em mulheres de camadas populares no Rio de Janeiro, RJ, Brasil: transformações e ressignificações. Interface: Comunicação, Saúde, Educação, Botucatu, v. 22, n. 65 , p. 435-466, 2017. 
PARKER, R. Stigma, prejudice and discrimination in global public health. Cadernos de Saúde Pública, Rio de Janeiro, v. 28, n. 1, p. 164-169, jan. 2012. PEIRANO, M. Etnografia não é método. Horizontes Antropológicos, Porto Alegre, v. 20, n. 42, p. 377-391, jul./dez. 2014.

PEIRANO, M. A favor da Etnografia. Rio de Janeiro: Relume-Dumará, 1995.

PINTO, M. S.; BOSI, M. L. M. Muito mais do que pe(n)sam: percepções e experiências acerca da obesidade entre usuárias da rede pública de saúde de um município do Nordeste do Brasil. Physis: Revista de Saúde Coletiva, Rio de Janeiro, v. 20, n. 2, p. 443-457, 2010.

PINTO, V. R. A. et al. Influence of package and health-related claims on perception and sensory acceptability of snack bars. Food Research International, Amsterdã, v. 101, p. 103-113, Nov. 2017.

PUHL, R. M.; HEUER, C. A. Obesity stigma: important considerations for public health. American Journal of Public Health, Washington, DC, v. 100, n. 6, p. 1019-1028, Jun. 2010.

RODGERS, R. F. The role of the "Healthy Weight" discourse in body image and eating concerns: an extension of sociocultural theory. Eating Behaviors, Amsterdã, v. 22, p. 194-198, Aug. 2016.

SANTOS, L. A. O corpo, o comer e a comida: um estudo sobre as práticas corporais e alimentares na contemporaneidade. Salvador: Edufba, 2008.

STUCKLER, D.; NESTLE, M. Big food, food systems, and global health. Plos Med, São Francisco, v. 9, n. 6, p. e1001242, 2012.

SWINBURN, B. A. et al. Strengthening of accountability systems to create healthy food environments and reduce global obesity. Lancet, Londres, v. 385, n. 9986, p. 2534-2545, Jun. 2015.

SWINBURN, B. A. et al. The global obesity pandemic: shaped by global drivers and local environments. Lancet, Londres, v. 378, n. 9793, p. 804-814, Aug. 2011.

VARTANIAN, L. R.; SILVERSTEIN, K. M. Obesity as a status cue: perceved social status and the stereotypes of obese individuals. Journal of Applied Social Psychology, v. 43, n. S2, p. E319-E328, 2013.

VICTORA, C. G.; KNAUTH, D. R.; HASSEN, M. N. A. Pesquisa qualitativa em saúde: uma introdução ao tema. Porto Alegre: Tomo editorial, 2000. 
WORLD HEALTH ORGANIZATION - WHO. Expert Committee on Physical Status: the use and interpretation of anthropometry: report of a WHO expert committee. Genebra, 1995. (Technical Series, 854).

ZALUAR, A. A máquina e a revolta: as organizações populares e o significado da pobreza. 2. ed. São Paulo: Brasiliense, 1994. 



\section{Sociabilidade e alimentação um estudo sobre arranjos simbólicos em grandes centros urbanos ${ }^{1}$}

CHRISTIANE AYUMI KUWAE, FRANCISCO ROMÃO FERREIRA, MARIA CLÁUDIA DA

VEIGA SOARES DE CARVALHO, SHIRLEY DONIZETE PRADO E LUISA FERREIRA DA SILVA

\section{INTRODUÇÃO}

A cidade contemporânea é um espaço ativo de concatenação de fluxos fragmentários e justapostos oriundos de diferentes experiências. A legitimação de distinções sociais nos modos de se alimentar dialoga com possibilidades e constrangimentos em olhares que misturam aspectos

1 Este texto deriva de um recorte das análises da tese Navegar é preciso: sentidos e significados da alimentação entre jovens em universidades públicas no Brasil e em Portugal em tempos de crises. A pesquisa foi desenvolvida com o apoio da Fundação de Amparo à Pesquisa do Estado do Rio de Janeiro (Faperj), por meio de bolsa de doutorado e da Coordenação de Aperfeiçoamento de Pessoal de Nível Superior (Capes) pelo Programa de Doutorado-Sanduíche no Exterior (PDSE), processo n 99999.007200/2014-05. 
modernos e tradicionais do comer. Os grandes centros negociam significados e se organizam com uma identidade móvel que produz novas sensibilidades. (CANEVACCI, 1997, 2001) A mistura de experiências nos percursos urbanos de circulação dos citadinos atribui sentidos e significados aos objetos flutuantes nas relações humanas.

A partir desses referenciais, ocupamo-nos no presente estudo de arranjos simbólicos negociados na paisagem urbana como um modus operandi em direção a uma organização no cotidiano de jovens universitários. A análise está baseada no conceito de bricolagem cunhado por Lévi-Strauss no estudo de mitos e narrativas e na perspectiva teórica de Pierre Bourdieu, que apoia a articulação dos conceitos de habitus, jogo simbólico e distinção social.

Focalizamos as observações em dois grupos de jovens universitários, um na Universidade de Lisboa (UL), em Portugal, e outro na Universidade Federal do Rio de Janeiro (UFRJ), no Brasil. Foi desenvolvida análise de cunho etnográfico nos espaços universitários e nos circuitos desses jovens nas cidades de Lisboa e do Rio de Janeiro com o objetivo de compreender as operações mentais que impulsionam os arranjos simbólicos nas práticas de alimentação, considerando o cenário urbanizado desses dois grandes centros. A arquitetura social das cidades traz memórias de um passado que é retomado aos poucos, juntamente com os sonhos futuros e, no dia a dia, abriga novas sensibilidades que motivam mudanças mais articuladas do que a princípio se poderia pensar. "Quando tudo muda, do pequeno e imediato ao vasto e abstrato [...], parece não haver lugar para se posicionar, de modo a localizar exatamente o que mudou [...]". (GEERTZ, 2012, p. 9)

A convivência histórica de Brasil e Portugal, há mais de quatro séculos, mistura particularidades e universalidades em torno da alimentação: de um lado, a padronização de modos de viver e de comer; por outro, a valorização cada vez mais intensificada da diferença. Há particularidades em polêmicas, dissidências, testemunhos, continuidades e rupturas no "comum" (JULLIEN, 2010) que convivem na cultura local, simultaneamente com uma disposição para cultura global. As pretensões de um 
universal global não escapam às experiências vividas cotidianamente nas ruas das cidades; elas misturam-se e compartilham símbolos e signos. O que nos interessa nas idas e vindas deste estudo entre Brasil e Portugal é a construção social de arranjos simbólicos que dão sentido às práticas alimentares no espaço social de jovens estudantes de universidades em Lisboa e Rio de Janeiro, que são cidades com um grande fluxo de turistas, produtos, serviços e ideias. Os perfis dessas duas cidades facilitam a bricolagem nas artes, identidades, relações sociais e nos modos como os sujeitos lidam com os aspectos simbólicos da comida no cotidiano.

Por arranjos entendemos uma série de elementos constitutivos do sistema culinário que flutuam na cultura, seja em modo objetivado, seja em forma de imagem bruta ou abstraída, antes de se materializar na prática em categorias objetificáveis. Como exemplo, podemos mencionar categorias citadas por Gonçalves (2007), como a obtenção dos alimentos, seleção e processo de preparação, os saberes culinários, modos à mesa, classificações quanto à organização de pratos principais e complementares, equipamentos e utensílios, enfim, todas operam como categorias na organização de refeições que hierarquiza elementos desse sistema, ressignificando e bricolando elementos presentes no universo do senso prático. Podemos pensar também nos novos arranjos da comensalidade que hoje, cada vez mais, incorporam as lógicas das mudanças ocorridas no universo da informação, da tecnologia e das redes sociais. A possibilidade de sentar para comer em uma mesma mesa, embora cada um esteja conversando com outras pessoas ou em contato com informações de outros lugares, coloca em cena outra comensalidade e um novo conceito de sociabilidade.

Considerando que os arranjos simbólicos são realizados in loco, partimos da pluralidade de ofertas alimentares envolvendo uma geração de jovens universitários que habitam áreas urbanas. As cadeias internacionais de fast-foods se apresentam de modo universalizado, a exemplo de McDonald's, KFC ou Burguer King, que ocupam as ruas das duas cidades com uma infinidade de lojas padronizadas, mas que negociam adaptações de tipos de lanches nos cardápios: a lanchonete 
McDonald's, em Lisboa, inclui no seu menu sopa e bifanas, sanduíche com carne de porco muito comum, em Portugal; e o KFC, no Rio de Janeiro, oferece pratos com arroz e feijão. Ao lado das lojas das cadeias internacionais, essas metrópoles reproduzem o estilo fast-food em cadeias nacionais e regionais, como Loja das Sopas e A Padaria Portuguesa, em Lisboa, e Habib's e Rei do Mate, no Rio de Janeiro.

Há também opções alimentares de pequenos restaurantes que oferecem comida caseira, seguindo um menu considerado tradicional em cada país, os restaurantes gourmet ou de culinária internacional com pratos típicos em um cenário de diversidade cultural que alimenta a imagem de globalização. Mas se, de um lado, há uma aparente pluralidade ao incorporar os códigos locais, por outro, há também uma padronização dos gostos e produtos na medida em que a participação das empresas transnacionais do setor de alimentos está presente em vários países.

Nesse cenário, a comida de rua pode ser tida como um reduto de resistência a este processo de "macdonaldização" dos gostos e produtos. Temos, portanto, dois processos acontecendo simultaneamente: seja a valorização da comida local, seja a incorporação de um comer que tende ao padronizado e sua hibridização com a lógica do mercado global. Numa atividade bricoleur, os significados nos arranjos assumem um ordenamento que faz sentido para quem o organiza, embora possa parecer sem sentido para um observador que não adote um olhar distanciado. (CARVALHO, 2013; LÉVI-STRAUSS, 1976) O homem é capaz de atribuir significados aos alimentos. Além disso, os alimentos são - em termos do ciclo de atividades produtivas, sistema dietético e culinário distinções sociais, apelo comercial e disputas de poder, se entendermos que o significado é sempre arbitrário em relação às propriedades físicas do objeto de distinções.

A crescente participação de comidas prontas ou semiprontas e de alimentos ultraprocessados na alimentação moderna também se espalha no universo de significação como produto de uma industrialização prejudicial para as pessoas e para o planeta, mas que se sustenta por uma infinidade de justificativas: incorporação de novas ferramentas no 
cotidiano das moradias - como o freezer e o micro-ondas -; o deslocamento do trabalho das mulheres para fora do domicílio, a precarização das garantias do trabalhador com multiplicação de jornadas de trabalho - ou eliminação dos postos de trabalho com o desemprego -; a falta de tempo para cuidados com a alimentação das famílias - ampliando a jornada de trabalho e reduzindo os horários de lanches e almoços, além dos longos deslocamentos entre a moradia e o trabalho nas grandes metrópoles marcados por limitações nos transportes e pelo trânsito caótico e lento -, sem contar com a redução da renda e do poder de compra. Seja qual for o argumento que hoje orienta as políticas públicas de alimentação, as mudanças políticas e sociais liberais avançam de forma imperativa numa urbe cada vez mais atribulada.

Assim, observamos a retomada de antigas práticas, como a da comida de marmita, que é ressignificada nesse cenário como uma melhor opção em oposição à comida ultraprocessada, agora na condição de alimentação saudável. A retomada dessa prática nos dois centros urbanos é acompanhada da multiplicação de utensílios desenvolvidos para esse nicho de mercado. Deste modo, simbolicamente, a marmita no contexto da urbe é associada à individualidade e à praticidade, ou seja, como uma possibilidadede comer uma comida segura, feita com ingredientes selecionados de acordo com o gosto pessoal do comensal em qualquer lugar.

As negociações simbólicas dessa retomada envolvem nova divisão dos espaços internos de comensalidade nas urbes e que estavam presentes também nas universidades com novo status entre os universitários, mas sem deixar de continuar representando uma estratégia de redução de custo para alimentação. Cabe ressaltar que, tanto no Brasil como em Portugal, levar comida para o trabalho ou para a universidade tempos atrás era considerado algo condenável e, no passado recente, seu uso era mais restrito às classes populares e aos trabalhadores menos qualificados. Os trabalhadores de maior qualificação e poder salarial raramente utilizavam esse recurso; contudo, a crise e a medicalização da comida motivaram a ressignificar seu uso. 
As mudanças e permanências de significados produzem arranjos no sistema de classificação e apreciação estruturados e estruturantes de uma ordem social. A alimentação opera como uma linguagem sem palavras, a comida comunica afetos, intenções e expressões subjetivas nas relações nem sempre traduzíveis em nomes. O comer é efeito contínuo de um habitus, conceito de Pierre Bourdieu (2013), que opera esquemas de percepção imanentes ao corpo socialmente informado do citadino e que na cultura local hierarquiza as distinções sociais. A significação é um modus operandi de atribuição de significado reproduzido pelos atores sociais conectados com um universo de sentidos previsíveis na sociedade em que vivem. (BOURDIEU, 2009; SELTON, 2002; THIRYCHERQUES, 2006) Assim, a reincorporação da marmita no cotidiano veio acompanhada de um conjunto de produtos e serviços que ajudaram a "glamourizar" esses objetos e "gourmetizar" os alimentos, pois os formatos e os tipos de marmita, além da própria comida e de sua apresentação, não são os mesmos da classe trabalhadora e cria-se um novo conjunto de códigos sociais e subjetivações individuais acerca desses objetos.

O sistema de disposições duráveis segue um fio condutor no modo de perceber e sentir as coisas. As disposições são simbólicas e nessa condição operam como princípio gerador de práticas, exercendo, ao mesmo tempo, efeito e apreciação. O habitus, assim, organiza as práticas não como um destinatário de significados ou como um "produto de obediência a algumas regras" (BOURDIEU, 2009), mas como um motivador de adaptações concernentes às possibilidades no contexto in loco. As disposições, quase sempre invisíveis, se manifestam no senso prático como um princípio gerador que segue um objetivo sem uma intenção consciente, sem cálculo ou controle do que é necessário para alcançá-lo. Desse modo, o conceito de habitus atualiza na prática a forma "natural" através da qual os atores sociais atribuem significados ao seu comer, por eles compreendido como inquestionável porque segue uma ordem social.

De acordo com Carvalho (2013, p. 30), “a prática é uma contínua produção de sentidos e significados, sem que isso se apresente como um propósito claro para os atores nas práticas”. No caso das marmitas, por 
exemplo, por causa de uma crise global, ao lado do reconhecimento dos malefícios nutricionais das comidas ultraprocessadas, os códigos locais de reconhecimento e valoração dessa prática foram ressignificados. O habitus incorporou essa necessidade e inventou uma disposição simbólica favorável ao seu uso, mas manteve alguns códigos de distinção ao diferenciar as marmitas dos mais pobres das marmitas gourmet da classe média.

O comer na perspectiva de uma necessidade biológica integra a vida cotidiana como uma atividade naturalizada, inequívoca, diante da qual não há escolha quanto a fazê-la ou não: é natural comer para matar a fome. No entanto - e, justamente, por trazer essa centralidade como natureza -, nem sempre fica claro que a alimentação é permeável a diversas ordenações sociais em que o que é comestível é objeto de um "complexo sistema simbólico de significados sociais, sexuais, políticos, religiosos, éticos, estéticos etc". (CARNEIRO, 2003, p. 1) Podemos citar como exemplo o pão, que é o alimento símbolo da cristandade, comum em várias culturas, com presença na história de diferentes civilizações, mas que hoje é classificado a partir de inúmeros códigos e consumido ou evitado a partir de suas características de mercado - com ou sem glúten, lactose, grãos, fibras, farinha branca, farinha integral, nível de processamento na produção ou nacionalidade.

Consideramos que adversidade é também uma resposta criativa, própria do ser humano na adaptação a mudanças em relação ao que está disponível para consumo. A concentração populacional nos grandes centros urbanos flexibiliza as disposições para o comer frente à multiplicidade de opções alimentares incorporadas pelos citadinos,

produto de um processo simultâneo e sucessivo de uma pluralidade de estímulos e referências não homogêneas, não necessariamente coerentes. Uma matriz de esquemas híbridos que tenderia a ser acionada conforme os contextos de produção e realização. (SELTON, 2002, p. 67)

É a partir da luta contra a concepção de natureza herdada, ou destino, que nos propomos a analisar as práticas alimentares no espaço social de jovens universitários em metrópoles contemporâneas. 


\section{FILIAÇÃO TEÓRICA DO ESTUDO}

Localizar o referencial teórico visa, por um lado, retomar o diálogo entre pensadores envolvidos no que Pierre Bourdieu nomeia de uma sociologia de combate, sensível aos conflitos políticos e lutas associadas à imposição de sentidos ou de formas de classificação. Em sua problemática teórica, Bourdieu (1989) assume que há um poder simbólico invisível que só pode ser exercido com a cumplicidade daqueles que não sabem ou não querem saber que a ele estão sujeitos ou mesmo que o exercem. Essa perspectiva de jogo de forças delimitou nossas estratégias metodológicas para a investigação de operações mentais articulando conceitos como ferramentas - habitus, jogo simbólico, distinção social - para dar visibilidade ao processo de atribuição de significados como mecanismo de poder, conhecimento e comunicação.

Bourdieu (1989) articula questões praxiológicas na metodologia e reorienta o olhar para processos de classificação e lógicas de distinção de forma atenta à produção simbólica e às relações informais de poder. As rupturas que acabam sendo feitas quando uma ideia migra de um campo a outro podem permanecer em estado implícito, caso não se atente para o fato que essa imigração implica sempre algum dano, já que “[...] repatriar este produto de exportação implica riscos graves de ingenuidade e de simplificação - e também grandes inconvenientes, pois fornece um instrumento de objetivação". (BOURDIEU, 1989, p. 10)

Por outro lado, numa perspectiva mais comunicativa, acompanhamos o pensamento de Paul Ricoeur (1978, p. 30), que compreende a linguagem como relação consensuada entre atores que se apropriam dos sentidos por um pensamento da ordem vigente, correspondendo a um pensamento que não se pensa “[...] uma explicação em primeiro lugar limitada, em seguida, pouco a pouco ampliada, seguindo o fio condutor dos próprios problemas”. A compreensão de Ricoeur quanto ao sentido estar em suspensão no símbolo, entre o abstrato e o concreto, complementa o conhecimento praxiológico bourdiesiano. Nesse registro, a bricolagem é um consenso fruto de negociação de significados, 
consenso que tanto pode estar aprisionado na experiência quanto liberto dela quando protesta contra falta de sentidos. A bricolagem representa acordo em condição de equilíbrio precário que ordena e reordena a experiência.

No que concerne à Antropologia, a bricolagem envolve o pensamento selvagem cunhado por Lévi-Strauss no estudo de mitos e narrativas. O autor faz uma reflexão sobre os mitos como operadores de um inventário simbólico, uma espécie de tesouro de ideias que reproduz a estrutura social. Um signo tem existência datada, inerente à vivência, mas que não depende da razão ou consciência, pois a significação é uma necessidade de ser, uma necessidade humana. A existência do signo é imanente ao olhar sobre a imagem que constrói o signo:

O bricoleur está apto a executar grande número de tarefas diferentes; mas, diferentemente do engenheiro, ele não subordina cada uma delas à obtenção de matérias-primas e de ferramentas, concebidas e procuradas na medida do seu projeto: seu universo instrumental é fechado e a regra do seu jogo é a de arranjar-se sempre com os meios-limites, isto é, um conjunto, continuamente restrito, de utensílios e de materiais, heteróclitos, além do mais porque a composição do conjunto não está em relação com o projeto do momento, nem, aliás, com qualquer projeto particular, mas é o resultado contingente de todas as ocasiões que se apresentaram para renovar e enriquecer o estoque, ou para conservá-lo, com resíduos de construções e de destruições anteriores. (LÉVI-STRAUSS, 1976, p. 38)

Na bricolagem alimentar, todos os significados podem ser renegociados de modo aparentemente caótico antes que uma decisão em consenso seja tomada no processo comunicativo da linguagem.

O desejo comum de ser atraente para o sexo oposto, por exemplo, pode ser usado desse modo para ajudar a vender qualquer coisa, desde creme contra manchas ou cigarros até aperitivos [pois] são os significados simbólicos que se acham vinculados aos produtos. (CAMPBELL, 2001, p. 73)

Trata-se de um processo que não é irracional, como acusam alguns, nem sem sentido e fora do controle. Nessa corrente teórica, a linguagem não pode ser encarada como repreensível e desfavorável a uma "natureza 
humana", pois, embora sem necessariamente termos consciência disso, a associação de imagens e sensações é apreendida culturalmente.

\section{OBSERVANDO OS CAMPI UNIVERSITÁRIOS}

O espaço urbano mistura o tradicional e o moderno na informalidade cotidiana do ir e vir dos alunos nos campi. Os encontros e as trocas simbólicas vivenciados foram expressão de significados que, no contexto analisado, fazem sentido, levando-se em conta a sensibilidade dos jovens para o senso prático. Articulando bricolagem nos termos de Lévi-Strauss (1976) - na condição de uma ciência primária, antes de primitiva -, ao senso prático de Bourdieu (2009), orientamos na estratégia metodológica a intimidade e a afetividade com o universo de significação. A observação participante ocorreu no ano de 2015, no Instituto Superior de Ciências Sociais e Políticas (ISCSP) da UL, Portugal e, em 2016 e 2017, no Instituto de Filosofia e Ciências Sociais (IFCS) da UFRJ, Brasil, e esteve sensível às relações dos jovens universitários com os objetos, permitindo que eles transformem sua condição de existência de acordo com suas formas de ver o mundo.

O espaço físico observado seguiu um fluxo de pessoas que transitava nos restaurantes, refeitórios, salas de aula e áreas de convivência, incluindo os arredores dos campi universitários e domicílios, quando havia comemorações situadas em outros espaços das cidades que não os das universidades. O comer estruturou e também foi estruturado, nesses espaços físicos com e pela agregação de pessoas. Cada pequeno núcleo espacial nessas urbes configura um microcosmo de ordenação simbólica com conexões para uma rede de relações sociais com outros núcleos ou pessoas, desde que "situado (e [...] reconhecido como tal) numa peculiar rede de relações”. (MAGNANI, 2002, p. 21)

A observação se estendeu ao espaço virtual de comunicação global envolvendo as novas Tecnologias da Informação e Comunicação (TIC), entendendo que se trata de espaços reais, ainda que virtuais, com efeitos no mundo "físico", como explica o sociólogo espanhol 
Manuel Castells (2009), e que compõem o cenário urbano. O fenômeno da transmidialidade é um eixo estruturado e estruturante de uma "cultura da convergência" (JENKINS, 2006), um traço distintivo das redes sociais que, segundo Scolari (2013), desliza a história ou narrativa para/por várias mídias. A ideia de comensalidade virtual (CARVALHO; PERES-NETO, 2016) assume uma função social na pluralidade de alternativas discursivas e, nessa condição, reflete o universo de significação dos jovens em questão.

A análise que desenvolvemos inclui abstrações espaçotemporais oriundas de um processo de aceleração tecnológica (JAMESON, 1996), que pulverizam de significados esse "tesouro de ideias". A sociabilidade nesse cenário não somente extrapola fisicamente os muros da universidade, como virtualmente o momento presente, deslocando objetos transmidializados no tempo. O comer dos jovens não é tão materialista quanto parece, com o preço da refeição não sendo o único e nem sempre o mais importante elemento do devaneio que estimula o consumo.

\section{CULINÁRIA STAND-UP: DA BIFANA AO PODRÃO}

A concatenação de interpretações por parte dos meios de comunicação socializa um sistema classificatório no cotidiano das ruas das cidades que configura um processo permanente de integração entre produção e consumo, que nos fez perceber tendências de estilos como o stand-up nos dois campi, corroborando o que Canevacci $(1997,2001)$ denomina de fluxos fragmentários e justapostos oriundos de diferentes experiências.

A culinária dos estudantes, que estamos denominando stand up, expressou múltiplas práticas alimentares motivadas pela disposição para subsistência e resistência dos jovens vivendo em uma grande metrópole, seja pela falta de recursos propriamente dita, seja pelo status que se constrói na ideia de "ser econômico". Tal condição se estende em suas ações nos campi e adjacências como um modo criativo e original de preparar e socializar uma comida. O custo da comida tem um peso considerável na determinação das opções entre os jovens nos dois campi 
de observação. As estratégias para economizar dinheiro no orçamento restrito acompanham todas as práticas alimentares observadas entre os jovens nos dois contextos.

É uma culinária que prima pela informalidade e pela criatividade, na qual o sanduíche poderia ser representante da bricolagem alimentar com sua diversidade de recheios e complementos. Sua estrutura dietética consiste em uma base de pão com designs variados - pode ser em forma de disco como o pão árabe, cone, duas fatias, um pão almofadinha ou bisnaga cortados ao meio etc. - que abriga recheios que sempre hão de corresponder a uma ampla miríade de opções. Uma estrutura que vai no bojo da tendência da resistência juvenil aos padrões tradicionais socialmente estabelecidos, permitindo que se coma sem prato ou talheres, sem ter que se sentar à mesa, em pé ou mesmo andando.

Um ponto em comum nos dois cenários da pesquisa foi a escolha de sanduíches como opções alimentares noturnas nos contextos das festas universitárias. Observamos preferência pelo hambúrguer (McDonald's e "podrão"), ${ }^{2}$ salsicha ou kebab. Por mais que esses três tipos de carnes estejam vinculados a culturas alimentares distintas, sendo duas mais globalizadas (hambúrguer e hot dog) e outra mais regional (como o Ke$b a b$, uma marca da imigração indiana e pasquitanesa na Europa), os correspondentes sanduíches estão presentes, tanto de Lisboa quanto do Rio de Janeiro, com o mesmo sentido: são baratos e substanciosos, propícios para os jovens, como opções de comida na madrugada urbana.

O sanduíche foi apresentado no trabalho de campo como uma comida simbolicamente ligada à juventude e à cidade, principalmente, o hambúrguer. A popularização desse tipo de sanduíche ocorreu junto ao

2 Sanduíche que se assemelha ao cachorro-quente, comercializado em trailers, quiosques, carrocinhas e barracas. É um cachorro-quente incrementado com vários ingredientes à escolha do consumidor, tais como: ovos de codorna, passas, azeitonas, batata palha, molhos diversos, queijo parmesão ralado, cenoura ralada, ervilhas em conserva, milho em conserva e beterraba ralada, além de maionese, mostarda, ketchup e o que mais possa ser considerado apetitoso e que venha a matar a fome, em particular, na madrugada. Guardando certo tom irônico e brincalhão, o nome "podrão" - como aumentativo de "podre" - refere-se aos padrões de higiene, em geral, negativamente associados à comida comercializada por ambulantes na noite urbana. 
surgimento da cultura juvenil, assim como o jeans, o rock e o cinema. (BARBOSA; CAMPBELL, 2006; FEIXA, 2006) Marca presença cotidiana como uma comida emblemática da metrópole e dos valores de modernidade, praticidade e rapidez, representando, nesse cenário das duas cidades nos circuitos universitários observados, um modo globalizado de ser jovem. (BLEIL, 1998; CANEVACCI, 1997)

Uma culinária stand-up não se opõe rigidamente a adaptações de uma cozinha tradicional. A versão da preparação de pratos típicos para uma forma industrializada é ressignificada para ajustar-se ao contexto, o que flexibiliza o sentido de tradicional. O simbolismo de tradicional, regional, caseiro e artesanal é dinâmico nas trocas simbólicas. É na realidade de um contexto específico que as ideias de tradicional se fundem - ou não - com as de moderno, alcançando distinção social. A ideia global de sanduíche como comida moderna, jovem e prática se ressignifica no tempero local, no qual:

[...] os alimentos estão sendo continuamente reinterpretados, reinventados, sendo alguns excluídos outros re-introduzidos e outros ainda sendo transformados a fim de se adequar às exigências da vida urbana e acelerada. Na bricolagem alimentar um alimento desprezado em seu consumo cotidiano, pode ganhar destaque em um outro momento, e vice-versa. (CARVALHO, 2013)

Em Lisboa, uma opção comum nas festas universitárias e nos cardápios das lanchonetes são as bifanas, sanduíches com recheio de carne de porco. Uma comida tradicional da culinária portuguesa que se mantém no cotidiano citadino, incorporado tanto no cardápio de fast-foods como também nas festas lisboetas e universitárias.

No caso dos estudantes do Rio de Janeiro, quanto maior a diversidade nos recheios dos sanduíches, mais atraente eles ficam, por vezes apelidados de "podrão". As regras das misturas que inserem os complementos são legitimadas na experiência que permite que se prove algo novo na hora de fazer o sanduíche, de acordo com a disponibilidade local. Em geral, são ingredientes do cotidiano de baixo custo e longa validade, duráveis; no caso do cachorro-quente, a linguiça é uma opção à 
salsicha. Mas não são misturas totalmente aleatórias, pois os ambulantes que não se apropriam das opções certas não se estabelecem na rua por muito tempo.

Ainda no estilo stand up de comer, entre o cachorro-quente e o hambúrguer, há os salgados. Salgado é um nome genérico para denominar uma variedade brasileira de comidas de lanches rápidos, como a coxinha, o bolinho de aipim com carne seca, enroladinho de salsicha, que são fritos na hora na barraca do vendedor ambulante. Esse tipo de comida - os salgados - é mais "brasileiro" se comparado com os sanduíches. Nesse aspecto, a coxinha ${ }^{3}$ merece destaque, já que é uma comida tomada como ícone do Brasil entre os imigrantes no exterior. (ROCHA; RIAL; HELLEBRANDT, 2013) Desse modo, a coxinha é alçada à condição de uma comida totêmica e representativa da culinária brasileira, assim como ocorre com a feijoada. O aipim, também chamado de macaxeira ou mandioca em outras regiões do país, é outro ingrediente nacional marcante da culinária, assim como a carne seca é um alimento regional ligado ao Nordeste brasileiro. (CASCUDO, 2004) Esses sabores regionais demarcam a presença de comidas ligadas ao gosto e à culinária brasileira entre as opções de comida de rua de jovens universitários do IFCS-UFRJ e que, semelhante ao pão com chorizo e ao caldo verde para os estudantes do ISCSP-UL, são comidas que podem ser também consideradas como comfort foods. (GIMENES-MINASSE, 2016)

É possível tomar essa categoria de comida - comfort foods - em oposição simbólica ao kebab ou ao hambúrguer ou o cachorro-quente. $O$ pão com chorizo e o caldo verde são comidas afetivas com forte ligação cultural com os jovens portugueses, ao contrário do kebab e do McDonald's, que são comidas globalizadas e remetem a valores de modernidade, assim como, no Rio de Janeiro, os salgados guardam mais ligação com a culinária nacional que o hambúrguer e o cachorro-quente. Ao lado dessa

3 Quitute popular frito, empanado e salgado em formato de coxa de galinha, o que the dá o nome, com recheio de carne de frango, cujas unidades são vendidas em bares e restaurantes como entrada ou lanche. 
oposição simbólica observada nos dois grupos, a comercialização dessas comidas ditas tradicionais na madrugada também representa uma modernização da tradição e permite analisar como as comidas ditas tradicionais são reorganizadas e reproduzidas na contemporaneidade, permanecendo no gosto dos jovens.

Nestas comidas de madrugada stand up, cabem modos mais tradicionais bricolados a partir de uma disposição dos jovens para práticas alimentares que remetem à família e à tradição alimentar de cada cidade. Desse modo, podemos considerar que essa disposição para comer um pão com chorizo no fim de uma noite com amigos revela sentidos na atualização de um gosto. Registremos, ainda, que, tanto no Rio de Janeiro como em Lisboa, um fenômeno recente aponta para uma "tendência" do mercado no sentido da "gourmetização" dos produtos, principalmente do hambúrguer, incorporando carnes nobres, molhos e temperos "diferenciados", além de misturas com pães de formas, cores e sabores inusitados. Nessa linha, a novidade do momento - os carros do tipofood-trucks - traz não apenas apelo por uma comida de rua mais próxima da gastronomia que se apresta com mais distinção, incluindo os próprios vendedores que também diferenciam seu estilo de forma "original".

\section{SMARTPHONE: SÓ E ACOMPANHADO AO MESMO TEMPO}

As conexões digitais configuram um cenário de novas sensibilidades e novas formas de consumo alimentar. Ainda que não haja uma convivência física à mesa, há socialização de "mesas" virtuais que compartilham afetos, sentimentos e valores em redes sociais durante o ato alimentar. Quanto a esses novos espaços de comensalidade, se, por um lado, diferem dos convencionais, multiplicando-se em alternativas - porque representam uma impossibilidade de estar face a face, compartilhando uma mesa física em torno da qual se reúne um núcleo afetivo, seja ele familiar ou de amigos -, por outro, alinham-se com a multiplicação de possibilidades de convívio que as novas tecnologias proporcionam. 
Manter-se conectado e compartilhar o cotidiano virtualmente foi uma das práticas observadas nos dois campi entre os jovens universitários, inclusive nos momentos em que eles estavam comendo. Sentar à mesa para beber um café e conversar nos intervalos das aulas ou fazer as refeições no refeitório ou no pátio nunca era uma atividade solitária. Quando os jovens não estavam em grupo e comiam sem companhia física, presencial, mostravam-se acompanhados virtualmente em comunicação com outrem pelo smartphone.

Observamos que essa juventude convive com uma sociabilidade mediada pela tecnologia em um fluxo ininterrupto de ofertas fluidas e plurais. (BARCELLOS; FREITAS; CARVALHO, 2016) É através da internet e do smartphone que os jovens, assim como a maioria das pessoas nos campi, se comunicavam, organizavam seus trabalhos acadêmicos, buscavam informações, ouviam música e mantinham-se conectados, atualizando-se no mundo, compartilhando inquietações e dividindo seu cotidiano de vida, incluído o alimentar: o que, com o que, com quem, como e onde comem.

O smartphone e a internet proporcionam uma conjugação de trabalho e lazer em qualquer lugar e a todo tempo e, desse modo, passaram a penetrar no cotidiano com funções variadas como meio de comunicação, entretenimento, ferramenta de trabalho, indissociável e essencial ao cotidiano, principalmente nos grandes centros urbanos. Segundo Castells (2016), essa mudança extrapola a questão comunicacional e, ao lado de outras mudanças, ressignifica o tempo com uma instantaneidade de comunicação e a construção de uma nova forma de sociabilidade em que há dissolução das divisões de tempo e espaço nas refeições, já que essa tecnologia permite compartilhar qualquer acontecimento com uma rede de pessoas no momento e em qualquer lugar do mundo desde que haja conexão com a internet.

A tecnologia de comunicação generalizou-se no mundo. Em 1995, havia cerca de 40 milhões de usuários da internet; já em 2009, esse número passou para 1,5 bilhão de usuários. (CASTELLS, 2016) Em 2015, cerca de 3,2 bilhões de pessoas estão conectadas à rede, o que representa $52 \%$ 
da população mundial, sendo esses dados referentes somente ao número de pessoas conectadas pela rede de internet fixa. Quando se considera a rede de internet móvel, cerca de $96 \%$ da população mundial tem acesso à rede de segunda geração tecnológica $(2 \mathrm{G})$ e $78 \%$ à rede 3G. (INTERNET, 2016)Considerando essa penetração massiva de novas modalidades de comunicação no cotidiano, Castells (2016) entende que vivemos uma mudança na nossa sociabilidade relacionada com esse modo de comunicação, que é caracterizada pela interconectividade instantânea e permanente e que proporciona sensações de proximidade e simultaneidade.

A geração jovem observada nos campi cresceu lado a lado com a popularização do computador e da internet e da sua penetração no cotidiano das pessoas. A incorporação de discursos pode se desdobrar infinitamente, segundo Carvalho e Peres-Neto (2016), ressignificados ao longo do tempo como um filme de cinema que passa de geração a geração e acolhe diferentes interpretações. O sentido no uso de aparelhos celulares se deu como um novo arranjo de sociabilidade relacionada à possibilidade de manter-se sempre acompanhado virtualmente através do compartilhamento de mensagens, vídeos e fotos instantâneas proporcionadas pela tecnologia. Tal arranjo esteve naturalizado no convívio social dessa geração, crescendo pari passu com a expansão dessa tecnologia e numa época em que estar conectado tornou-se um imperativo social.

Nossas observações em relação ao uso intensivo do celular pelos jovens universitários foram semelhantes às de Castro e colaboradores (2017), que também indicavam na sua pesquisa sobre as práticas alimentares universitários que, nas cantinas, os jovens sempre se sentavam em grupo e, quando estavam sozinhos, estavam acompanhados dos seus smartphones, notebooks, tablets ou qualquer outra parafernália eletrônica acompanhando os momentos de refeição.

Portanto, o que percebemos ao longo do trabalho de campo era que o smatphone era usado como um "acompanhante virtual" e, desse modo, os momentos das refeições entre os grupos observados nunca eram solitários, mesmo que o comensal estivesse sozinho na mesa. Comer nesse contexto era uma comensalidade acompanhada real ou virtualmente, 
em que o compartilhamento de imagens e discursos trazia o sentido do compartilhar a mesa. Segundo Carvalho e Pere:s-Neto (2016, p. 62), o efeito dessa forma cibernética:

[...] expõem um ethos solitário de internautas, em sua desnuda intimidade, de tal sorte que facilitam a construção de uma comensalidade compatível com uma sociabilidade volátil, algumas vezes presencial outras não, mas sempre sujeita a discursos que circunscrevem grupos, amores e resistências em um convívio arisco.

Um dos aspectos primordiais da alimentação é o convívio social. A comensalidade é um termo utilizado para denominar os aspectos sociais e simbólicos presentes no ato de comer. Etimologicamente, a palavra que deriva da junção latina de cum + mensalis, ou seja, com + mesa, significa, literalmente, compartilhar a mesa. Em linhas gerais, a comensalidade é um termo geralmente utilizado para denominar a partilha da comida (à mesa) por um grupo de pessoas. No entanto, diversos autores apontam a variedade de significados que estão associados a esse termo. (FISCHLER, 2011; KERNER; CHOU; WARMIND, 2015)

Tradicionalmente, a comensalidade esteve associada à partilha da comida e da mesa; no entanto a diversidade de práticas alimentarem trazem o debate sobre potencialidades e paradoxos de uma comensalidade virtual. Se há quem defenda que não dividir mais a mesma comida e a mesma mesa simbolizaria o enfraquecimento dos laços sociais pela sobreposição do individual em relação ao que está no plano coletivo da sociedade (FISCHLER, 2011; MENNELL; MURCOTT; VAN OTTERLOO, 1992; MOREIRA, 2010), há também quem defenda o papel do campo da comunicação/educação como agência de socialização capaz de reconfigurar a cultura orientando sentidos e novas sensibilidades na prática. (BACCEGA, 2009; CARVALHO; PERES-NETO, 2016)

Em nossa observação, a ideia de individualização da alimentação, que seria expressa através do comer sozinho ou de comer simultaneamente à realização de outras atividades, não encontra sustentação, uma vez que a prática observada esteve mais centrada no compartilhamento da companhia que na comida em si. O que observamos entre os jovens 
universitários era que comer junto continuava sendo um momento importante de coesão social e de estabelecimento de vínculos sociais de pertencimento. Fazia mais sentido comer com os amigos, mesmo que eles estivessem presentes virtualmente e mesmo que eles não dividissem as mesmas concretudes de mesas e comidas, do que comer sozinho.

Se compreendermos a comensalidade como uma ação simbólica de coesão social e pertencimento a um grupo, podemos indicar que a multiplicidade das práticas alimentares observada entre os jovens - como das diferentes comidas que não são partilhadas ou de comer virtualmente com o outro através do smartphone - não significa uma diminuição dos valores simbólicos em comunicação, apesar da mudança das práticas alimentares.

Essa prática observada do uso do smartphone durante os momentos de refeição reforçava os vínculos sociais dos jovens com determinados grupos. A manutenção virtual de uma rede seletiva permitiu aos jovens o permanecer em conexão no mesmo instante com pessoas, lugares e seus interesses pessoais. Essa mudança tecnológica de sociabilidade modifica não só as relações sociais no cotidiano, mas também as relacionadas com a alimentação, como as observadas nos campos de pesquisa. O uso de smartphones pelos jovens universitários era uma possibilidade de aprofundar o vínculo social entre determinados círculos de relação pessoal, já que a interconectividade virtual é instantânea, permanente - desde que haja internet e bateria - e também é direcionada, pois, ao mesmo tempo em que se conectavam a uma rede específica, também se isolavam de outras interações do cotidiano. As interações sociais urbanas tendem a se desenvolver somente dentro de determinadas redes. (SIMMELS, 2006) Assim, o sujeito está, ao mesmo tempo, permanentemente só e acompanhado na cidade. (CASTELLS, 2016)

\section{CONSIDERAÇÕES FINAIS: CONVERGÊNCIAS, DIVERGÊNCIAS E HIBRIDIZAÇÕES}

Podemos, então, considerar que o cenário metropolitano tece arranjos e narrativas de vivências e sensibilidades a partir do estoque de resíduos 
de construções anteriores, renovando-se com memórias que se organizaram, marcando convergências, divergências e hibridizações nos dois campi, com os dois grupos de estudantes. São arranjos do cotidiano das experiências nos percursos urbanos dos jovens nas cidades estudadas.

Os arranjos simbólicos incorporam novidades, hibridizações a partir da lógica global do mercado e invenções na cultura local em torno do comer e flutuam em um universo circunscrito ao momento e ao contexto social sempre no limite, sem projeto a priori. Podem parecer limitados inicialmente, mas, em seguida, com o uso cotidiano, ampliam-se conectando outros significados num equilíbrio precário entre estrutura e acontecimento, necessidade e contingência.

Conceitos como o de bricolagem, assim como de sistemas de disposição e estruturação de práticas alimentares foram ferramentas-chave na análise de novos esquemas de percepção nos circuitos de significação na vida universitária de jovens universitários que demonstraram que a tendência à hibridização, ainda que aparentemente diversa e desordenada, segue a construção de uma sociabilidade em cada um dos dois campi estudados.

A crise econômica impulsiona a ressignificação de novas práticas de alimentação e, considerando o cenário urbanizado das cidades do Rio de Janeiro e de Lisboa, percebemos que o poder aquisitivo molda ou influencia relações de comensalidade dos jovens estudantes. Ao lado disso, estas também são influenciadas pelas políticas de saúde e pelas inovações mercadológicas de novos utensílios para fazer refeições fora de casa. Levam a mudanças das práticas alimentares dos jovens como a "invenção" de uma marmita, que não significa apenas contingência, mas também cuidado com o corpo, a saúde e os gostos pessoais.

Os códigos de reconhecimento mudam para manterem-se vivos e, ainda que sejam ressignificados quase que totalmente, continuam existindo de acordo com uma ordem social hierarquizada de valores. A hierarquia reordena a experiência e orienta, assim como também é orientada por operações mentais de reconhecimento de status e privilégio nos campi, como os presentes na alimentação. 
As redes de fast-food são comuns em Lisboa ou Rio de Janeiro: ou são as mesmas casas ou obedecem às mesmas lógicas como uma "macdonaldização" do mercado de alimentos. Os produtos globalizados estão presentes nos diferentes espaços e são apropriados segundo a dinâmica do mercado local, mas não escapam de uma lógica capitalista estruturante de um consumo irrestrito, estruturada pelo lucro como núcleo central.

Observamos que as novas tecnologias da comunicação afetam de forma semelhante os dois grupos de jovens; eles se relacionam com o que consomem ou deixam de consumir em um desenho mosaico de alternativas cibernéticas flutuantes que conjugam trabalho e lazer em qualquer lugar e a todo tempo. As funções variadas de comunicação criam entretenimento e operam como ferramenta de trabalho de modo indissociável do convívio social cotidiano.

O que observamos sobre as práticas alimentares nos campi reafirma uma disposição para a bricolagem própria do cenário dos grandes centros, cujos sentidos reeditam tensões e afetos estruturados e estruturantes nas/das relações sociais dos jovens estudantes.

\section{REFERÊNCIAS}

BARBOSA, L.; CAMPBELL, C. (org.). Cultura, consumo e identidade. Rio de Janeiro: FGV, 2006.

BARCELLOS, D. M. N.; FREITAS, R. F.; CARVALHO, M. C. V. S.

Alimentação saudável e qualidade de vida: fenômeno midiático na cidade. Revista Eletrônica de Comunicação, Informação \& Inovação em Saúde, Rio de Janeiro, v. 10, p. 1-11, 2016.

BLEIL, S. I. O padrão alimentar ocidental: considerações sobre a mudança de hábitos no Brasil. Revista Cadernos de Debate, Campinas, v. 6, p. 1-25, 1998.

BOURDIEU, P. A distinção: crítica social do julgamento. 2. ed. São Paulo: EDUSP; Porto Alegre: Zouk, 2013.

BOURDIEU, P. O poder simbólico. Lisboa: Difel, 1989.

BOURDIEU, P. O senso prático. Petrópolis: Vozes, 2009. 
CAMPBELL, C. A ética romântica e o espírito do consumismo moderno. Rio de Janeiro: Rocco, 2001.

CANCLINI, N. G. A globalização imaginada. São Paulo: Iluminuras, 2007.

CANEVACCl, M. Antropologia da comunicação visual. Rio de Janeiro: DP\&A, 2001.

CANEVACCI, M. A cidade polifônica: ensaio sobre a antropologia da comunicação urbana. 2. ed. São Paulo: Estúdio Nobel, 1997.

CARNEIRO, H. Comida e sociedade: uma história da alimentação. Rio de Janeiro: Campus, 2003.

CARVALHO, M. C. V. S. Bricolagem alimentar nos estilos naturais. Rio de Janeiro: EdUERJ, 2013.

CARVALHO, M. C. V. S.; PERES-NETO, L. Comensalidade transmidiatizada e a construção de novas sensibilidades. In: FERREIRA, F. R. et al. (org.). Cinema e comensalidade. Curitiba: CRV, 2016. p. 51-68.

CASCUDO, L. C. História da alimentação no Brasil. 3. ed. São Paulo: Global, 2004.

CASTELLS, M. Communication power. Oxford: Oxford University Press, 2009.

CASTELlS, M. Fim do milênio. São Paulo: Paz e terra, 1999. (Trilogia A era da informação: economia, sociedade e cultura, v. 3).

CASTELLS, M. A sociedade em rede. 17. ed. São Paulo: Paz e Terra, 2016.

CASTRO, J. B. P. et al. Perfil do estilo de vida de universitários de Educação Física da cidade do Rio de Janeiro. Revista Brasileira Ciência e Movimento, Brasília, DF, v. 25, n. 2, p. 73-83, 2017.

CONTRERAS, J.; GRACIA, M. G. Alimentação, sociedade e cultura. Rio de Janeiro: Fiocruz, 2011.

FEIXA, C. De jóvenes, bandas y tribus: antropologia de lajuventud.

Barcelona: Ariel, 2006.

FISCHLER, C. Commensality, society and culture. Social Science Information, Thousand Oaks, v. 50, n. 3-4, p. 528-548, 2011.

GEERTZ, C. Atrás dos fatos: dois países, quatro décadas, um antropólogo. Rio de Janeiro: Vozes, 2012.

GEERTZ, C. A interpretação das culturas. Rio de Janeiro: LTC, 1989. 
GIMENES-MINASSE, M. H. S. G. Comfortfood: sobre conceitos e

principais características. Contextos da Alimentação, São Paulo, v. 4, n. 2 , p. 92-102, mar. 2016.

GONÇALVES, J. R. S. Antropologia dos objetos: coleções, museus e patrimônios. Rio de Janeiro: IPHAN, 2007. (Coleção Museu, Memória e Cidadania, v. 2).

INTERNET. State of connenctivity 2015: a reporton a global internet access. Menlo Park, 2016. Disponível em: https://fbnewsroomus.files.wordpress. com/2016/02/state-of-connectivity-2015-2016-02-21-final.pdf. Acesso em: 24 jul. 2019.

JAMESON, F. Pós-modernismo: a lógica cultural do capitalismo tardio. São Paulo: Ática, 1996.

JENKINS, H. Convergence culture. New York: New York University Press, 2006.

JULLIEN, F. O diálogo entre as culturas: do universal ao multiculturalismo. Rio de Janeiro: Zahar, 2010.

KERNER, S.; CHOU, C.; WARMIND, M. (org.). Commensality: from every day food to feast. New York: Bloomsbury Academic, 2015.

LÉVI-STRAUSS, C. Antropologia estrutural. Rio de Janeiro: Tempo Brasileiro, 1975.

LÉVI-STRAUSS, C. O pensamento selvagem. São Paulo: Editora Nacional, 1976.

MAGNANI, J. G. C. De perto e de dentro: notas para uma etnografia urbana. Revista Brasileira de Ciências Sociais, São Paulo, v. 17, n. 49, p. 11-29, 2002.

MENNELL, S.; MURCOTT, A.; VAN OTTERLOO, A. H. The sociology of food: eating, diet and culture. London: Sage: International Sociological Association, 1992.

MOREIRA, S. A. Alimentação e comensalidade: aspectos históricos e antropológicos. Ciência e Cultura, São Paulo, v. 62, n. 4, p. 23-26, out. 2010.

RICOEUR, P. O conflito das interpretações: ensaios de hermenêutica. Rio de Janeiro: Imago, 1978. 
ROCHA, C. P. V.; RIAL, C.; HELLEBRANDT, L. "Tapas" ou "coxinha":

alimentação, migrações e interculturalidade a partir dos blogs de brasileiros na Espanha. In: CONGRESSO INTERNACIONAL INTERDISCIPLINAR EM SOCIAIS E HUMANIDADES, 2, 2013, Belo Horizonte. Anais [...]. Belo Horizonte, 2013. p. 1-13.

SABINO, C.; CARVALHO, M. C. V. S. Estrutural-funcionalismo antropológico e comensalidade: breves considerações sobre a mudança social. Demetra: Alimentação, Nutrição \& Saúde, Rio de Janeiro, v. 8, p. 215-239, 2013. Suplemento 1.

SCOLARI, C. A. Narrativas transmedia: cuando todos los medios cuentan. Bilbao: Deusto, 2013.

SELTON, M. G. J. A teoria de habitus em Pierre Bourdieu: uma leitura contemporânea. Revista Brasileira de Educação, Rio de Janeiro, n. 20, p. $60-154,2002$.

SIMMELS, G. Questões fundamentais da sociologia: indivíduo e sociedade. Rio de Janeiro: Jorge Zahar, 2006.

THIRY-CHERQUES, H. R. Pierre Bourdieu: a teoria na prática. Revista de Administração Pública, Rio de Janeiro, v. 40, n. 1, p. 27-55, 2006. 


\section{Corpo, comida e rua interfaces produzidas na cidade}

\section{INTRODUÇÃO}

O itinerário alimentar do citadino põe em evidência múltiplas problemáticas que incidem na experiência da comensalidade na cidade. Tais questões estão atreladas à organização social das urbes, que, vista de uma perspectiva macro, contribui para desintegração da comensalidade tradicionalmente retratada por parte da literatura e constituída no seio das instituições sociais, particularmente da família.

A cidade está fincada na dinâmica da domesticação do tempo e do espaço pelo homem. Em sua composição, as estações do ano, períodos do dia e distâncias de marcha foram cedendo lugar às métricas, horas, calendários e símbolos que passaram a marcar sua temporalidade e espacialidade. A busca do homem em reger a movimentação da natureza 
tornou os ritmos cadenciados e os intervalos regularizados os liames do movimento nas urbes, elementos centrais na cadência da cidade. (LEROI-GOURHAN, 1975)

Assim, o espaço edificado possibilitando o habitat de número ascendente de residentes e a celeridade do cotidiano e do trabalho são aspectos que caracterizam o ambiente citadino, notadamente o das metrópoles. (LEROI-GOURHAN, 1975) Nesse processo, os ditames das horas, a centralidade do trabalho e os espaços compartimentados e funcionais das urbes provocaram alterações significativas nas experiências de tempo e espaço, incidindo fortemente nas dinâmicas alimentares urbanas.

Por um lado, a cidade promoveu um maior distanciamento de seus residentes da produção de alimentos; por outro, prometeu sua disponibilidade física ininterrupta, propiciada por um modelo agroindustrial de larga escala de produção. As maiores distâncias, particularmente entre local de trabalho e domicílio, e o tempo limitado para dedicar-se à gestão da alimentação agenciaram o deslocamento das refeições do espaço privado para o espaço público no cotidiano, o que repercutiu nos desenhos de comensalidade vivenciados no bojo dos arranjos urbanos, provocando novos ângulos e abordagens de investigação.

Nesse cenário, a comida de rua apresenta-se como uma possibilidade de fácil acesso à alimentação de modo rápido e, quase sempre, de baixo custo. Apesar de ser uma prática antiga, com estudos reportando sua existência desde o século XIX na Inglaterra (CALLONI, 2013) e, no Brasil, desde a época da escravidão (LIMA, 2007), o fenômeno na atualidade fornece elementos interessantes para refletirmos as possibilidades e constrangimentos envoltos nas experiências de comensalidade nas urbes contemporâneas.

A "comida de rua" no Brasil é comumente referida na literatura acadêmica a partir da tradução literal da definição de street food da Organização das Nações Unidas (ONU) para a Alimentação e Agricultura (FAO). (FAO, 1986 apud FAO, 1997) Street foods, segundo a definição, são considerados os alimentos e bebidas prontos para o consumo, preparados ou 
vendidos por comerciantes ambulantes, especialmente nas ruas e outros lugares públicos.

Tal constructo parece simplificar um conjunto de complexidades que perpassam a experiência de comer na rua, equacionando-a a aquisição e/ou consumo de alimentos ou bebidas adquiridos de vendedores ambulantes. Nesse processo, os corpos envolvidos no comércio e no consumo e a comida associam-se a um caráter instrumental que distancia a ideia de agência, colocando a "comida de rua" como uma espécie de essência, uma categoria dada, a priori, a partir da qual a investigação empírica se inicia e a ratifica.

Uma exploração da produção acadêmica mostra que, em parte dos estudos sobre o tema, a comida de rua é vista a partir de estereótipos, como alimentos que possuem má segurança higiênica e nutricional, associados a contextos de consumo e privação no mercado informal, como fonte de rendimentos para populações de baixa renda e sinal de má governança por parte do Estado, particularmente em países subdesenvolvidos. A maioria das publicações aborda a temática enfatizando seu aspecto higiênico-sanitário, bem como suas implicações na gestão do espaço urbano. Embora em menor proporção, as publicações referem-se ainda a questões como sua participação no desenvolvimento de doenças da modernidade, manejo de resíduos sólidos, acesso a insumos de qualidade e a caracterização dos alimentos vendidos na rua e de seus consumidores numa perspectiva hegemonicamente quantitativa. (BARKER; AMOAH; DRECHSEL, 2014; BEZERRA; MANCUSO; HEITZ, 2014; JOO; LEE; YOON, 2015; OKOJIE; ISAH, 2014; SOUZA et al., 2015; VIDAL JÚNIOR; CARDOSO; ASSUNCAO, 2013)

Destarte, as mútuas imbricações entre comida, corpo e rua no contexto das cidades implicam a necessidade de pensar abordagens teórico-metodológicas capazes de abranger complexidades produzidas nessas interfaces. O presente ensaio pretende contribuir nesse sentido ao resgatar elementos conceituais que têm potencial de interpelar a definição oficial de "comida de rua". Sob a guisa de fulgurar delineamentos teórico-metodológicos para uma pesquisa de doutorado, experimentamos 
avançar na superação da perspectiva de comida, corpo e cidade como instâncias decantadas durante a produção do conhecimento científico.

Para tanto, o trabalho desenvolve-se inicialmente com uma breve exploração de pressupostos da Teoria Ator-Rede (TAR ou ANT), a qual ambiciona enfrentar dicotomias constituídas no bojo das ciências. Tal incursão objetiva trazer subsídios para enfrentar as decantações acima mencionadas. Em seguida, são discutidos constructos centrais na problematização do objeto de análise "comida de rua". Por fim, numa perspectiva prospectiva, propomos a abordagem de tal objeto mediante as práticas de comer na rua em contextos situados, nos quais corpos, comida e cidade constituem redes de inter-relações, efetuando comensalidade atuadas na rua.

Ademais, no percurso de constituição do ensaio, privilegiamos problematizar, ainda que momentaneamente, as realidades produzidas nas quais os vendedores ambulantes de comida de rua, nomeados hierarquicamente de "informais" e "ilegais", constituem-se como um dos elementos humanos colocados em interação. Tal eleição se deu tanto por coadunar, grosso modo, com a concepção de street food da FAO, quanto por entendermos, mediante Mol (2002), que as práticas científicas e o conhecimento não apenas representam o real, mas provocam alterações nele, modificando e sendo elemento que interfere em outras práticas.

\section{BREVES CONTRIBUIÇÕES DE AUTORES VINCULADOS À TEORIA ATOR-REDE PARA PENSAR COMIDA DE RUA E COMENSALIDADE}

A abordagem do corpo que come nas ruas da cidade compondo comensalidades coloca para dialogar categorias teóricas como corpo, comida, cidade e rua, as quais provocam a problematização de uma das clássicas dicotomias presentes na seara das ciências, a saber: natureza e sociedade. Tal dicotomia fundamenta-se na concepção da existência de um mundo natural no qual se justapõe um mundo simbólico. Em tal asserção, admite-se a existência de uma natureza única que corresponde à realidade a ser observada pelas ciências da natureza, para a qual as diversas sociedades humanas constroem simbolismos, com o intuito de 
lidar com esse mundo, os quais seriam abordados pelas ciências sociais. (LATOUR, 2000)

Latour (1994) convoca a problematizar essa assimetria que, para ele, nunca existiu de fato. A prática consegue resolver tal dicotomia sem poder expressá-la. Nela, a separação construída entre mundo material e mundo social se pulveriza. O trabalho de purificação dessas duas instâncias pelos modernos permitiu que a natureza fosse mobilizada por eles na construção de suas sociedades, sem contanto deixar de ser associada ao seu caráter de transcendência. Por outro lado, permitiu que as sociedades modernas fossem edificadas mediante a mobilização da natureza, sem, contudo, abdicar da noção de mundo social construído pelo homem, o único ator de seu destino político. Assim, o autor critica a fantasia moderna na qual poder político e poder natural são considerados instâncias em separado.

A antropologia de Latour (1994) convoca a pensar e alterar a própria definição de mundo moderno. O termo "moderno", para ele, aponta para dois conjuntos de práticas. O primeiro é definido como "tradução" e permite o entrecruzamento de seres distintos, híbridos de natureza e cultura. E o segundo, a "purificação", coloca humanos e não humanos em duas zonas ontológicas distintas. O autor denomina o primeiro de redes que conectam, no mesmo plano, técnica, estratégias científicas, industriais, questões de ordem política, ética, entre outras. E o segundo de crítica, no qual o mundo natural, a sociedade com interesses estáveis e o discurso independente existem separadamente. O trabalho de purificação tentou livrar-se dos híbridos, ao mesmo tempo em que permitiu a sua proliferação. Portanto, o mundo moderno, embora híbrido como todos os coletivos, tem essa sua característica negada.

Em face da tripla participação do mundo em sociedade, discurso e mundo natural criada pela "purificação", Latour (1994) propõe que o mundo seja tratado por "redes" capazes de atravessar essas três segmentações. As redes, não sendo exclusivamente de natureza objetiva, social ou discursiva, constituem-se ao mesmo tempo reais, coletivas e discursivas. O autor questiona a própria noção de cultura como parte de um 
arsenal criado a partir do nosso distanciamento da natureza. Não existiriam culturas, nem uma natureza universal, "mas apenas natureza-culturas, as quais constituem a única base possível para comparações". (LATOUR, 1994, p. 102)

Desse modo, o autor nos leva a concluir que a modernidade não se conforma uma realidade, mas antes uma versão que tenta explicá-la, na qual a busca pela purificação leva à hibridização. As práticas de purificação, a crítica, levariam a supor que a produção científica, grosso modo, restringir-se-ia à natureza ou ao conhecimento, às "coisas-em-si". Porém, estes âmbitos não existem em suspenso, fora da sociedade. Assim, tal produção diz respeito ao envolvimento destas com os sujeitos e os coletivos, e não a um pensamento instrumental.

Segundo Latour (1994), a ciência não se torna universal, não ao menos da forma tradicionalmente assumida. Ela se propaga em rede, ao mesmo tempo em que cientistas e sua infraestrutura de trabalho se desenvolvem. Qualquer ciência está atrelada a essa rede de práticas. A propagação dos achados e procedimentos que se tornarão padronizados na sua produção acontece à medida que seus agentes humanos e inumanos se desenvolvem.

Nessa conjectura, o que propõe Latour não é uma semelhança total e absoluta entre humanos e inumanos, mas uma não imposição apriorística de uma "assimetria espúria entre ação humana intencional e mundo material de relações causais”. A sociologia das associações, apresentada por ele, concebe os elementos inumanos não como intermediários que transportam efeitos únicos, nem como receptáculos de simbolismos humanos, mas como atores que promovem modificações de distintas maneiras no curso da ação. Entretanto, isso não implica uma inversão universal na qual os inumanos determinariam a ação, mas a consideração de que eles provocam diferenças nela, sejam a estimulando, interrompendo, ensejando, permitindo, limitando, autorizando, entre outras. Por conseguinte, alude à ampliação das possibilidades de análise do o quê ou quem se torna agente na ação, devendo tal enfoque ser explorado desde o início da investigação. (LATOUR, 2012, p. 114) 
Portanto, a ação é produzida mediante conexões de elementos heterogêneos que se entrelaçam em redes constituídas sempre de forma provisória e situacional. O curso dela delineia trajetórias que permitem ao pesquisador seu rastreamento. Tais pressupostos são fundamentais na TAR, desenvolvida por Latour e outros teóricos como Annemarie Mol. Essa abordagem situa-os no âmbito da ontologia empírica que se volta às práticas aos eventos produtores de realidades. (MARRES, 2009)

Nesse sentido, Mol (2002) propõe as ontologias múltiplas, reportando a coexistência de múltiplas realidades produzidas mediante os distintos modos como elas são atuadas nos contextos. Contudo, sua proposição não pressupõe um real fragmentado em vários, mas instaura uma complexidade maior ao anunciar inúmeras realidades que se sobrepõem e interferem umas nas outras. Ademais, cabe ressaltar que o termo "atuação", utilizado por ela, não se refere a uma perspectiva de dissimulação, mas visa a enfatizar a centralidade das práticas em sua argumentação.

Em seu trabalho intitulado The Body Multiple, cujo objetivo é investigar como o corpo múltiplo e as doenças se fazem, Mol constrói uma etnografia privilegiando os aspectos práticos, nominada por ela de filosofia empírica. Ela insere a praxiografia como uma abordagem metodológica que abrange a amplitude dos agentes, instituições, instrumentos, artefatos, ambientes, entre outros, visando investir no que está efetuando realidades nos contextos. (MOL, 2002)

As não essencialidades das realidades e das redes a serem investigadas implicam a mudança do foco de análise. Ao invés de o que está em análise ser abordado por vários pontos de vista, interessa o modo como ele é atuado na prática, em suas praticalidades, materialidades e interações. Parafraseando Mol (2002, p. 55), o "objeto" é mais que um e menos que muitos. E é somente na investigação de sua efetuação prática que se torna possível tangenciar essa máxima. Ademais, o conhecimento passa a ser mobilizado nas práticas, operando também modificações nos agenciamentos, e não se constituindo somente como um discurso verdadeiro acerca da realidade. 


\section{O ALIMENTO E A COMIDA DE RUA}

DaMatta (1986) contribui com constructos teóricos para pensarmos a comida de rua no Brasil. Por meio da análise da sociedade brasileira, o autor constrói argumentos para distinguir as categorias "alimento" e "comida”. Muito embora reconheçamos a complexidade que perpassa essa discussão, a qual não se esgotaria neste ensaio, elegemos o autor para a problematização inicial devido a sua incursão seminal em torno do constructo "comida", bem como "rua”. A eleição almeja-se crítica tendo em vista seu potencial de confrontação com as ideias de Bruno Latour.

Diz DaMatta (1986, p. 36-37):

Alimento é tudo aquilo que pode ser ingerido para manter uma pessoa viva, comida é tudo que se come com prazer, de acordo com as regras mais sagradas de comunhão e comensalidade. Em outras palavras, o alimento é como uma grande moldura; mas a comida é o quadro, aquilo que foi valorizado e escolhido dentre os alimentos; aquilo que deve ser visto e saboreado com os olhos e depois com a boca, o nariz, a boa companhia e, finalmente, a barriga...

O alimento é algo universal e geral. Algo que diz respeito a todos os seres humanos: amigos ou inimigos, gente de perto ou de longe, da rua ou de casa, do céu ou da terra. Mas a comida é algo que define um domínio e põe as coisas em foco [...]. Por outro lado, comida se refere a algo costumeiro e sadio, alguma coisa que ajuda a estabelecer uma identidade, definindo, por isso mesmo, um grupo, classe ou pessoa. [...] comida não é apenas uma substância alimentar, mas é também um modo, um estilo e um jeito de alimentar-se.

Nessa perspectiva, a comida de rua diferiria do alimento de rua. $\mathrm{O}$ alimento de rua estaria associado àquilo que é ingerido para saciar as necessidades físicas, o passível de ser comestível na rua para manter-se vivo. Já a comida de rua estaria relacionada à ação do homem, aos modos de comer, à sociabilidade em torno do comer na rua, comportando assim o constructo "comensalidade".

$\mathrm{O}$ alimento de rua, portanto, pertenceria à ordem da natureza, objeto de investimento da ciência da Nutrição, a qual se estruturou 
majoritariamente a partir da racionalização do ato alimentar, privilegiando os aspectos mensuráveis dos alimentos, constituindo-se parte do campo biomédico. (BOSI; PRADO, 2011) Numa analogia à discussão da assimetria moderna criticada por Latour (1994), poderíamos dizer que os alimentos corresponderiam ao domínio das ciências naturais, equacionados a coisas, elementos inertes e mudos que têm como interlocutores e tradutores os cientistas. Representados pela ciência, dissociados da política, caberia ao cientista desvendá-los, descobrindo o que há na natureza.

A comida de rua, por outro lado, estaria associada ao âmbito da sociedade, da cultura, da produção humana. Os simbolismos inscritos na superfície natural dos alimentos, transformando-os socialmente em comida, possibilitando aos homens dominar esse elemento e saciar suas necessidades, colocariam tal objeto de estudo no domínio das ciências sociais. Portanto, constituída nas relações sociais, a comida de rua teria como característica a possibilidade de agregar humanos em volta de si, dar sentido, constituir identidades, construir memórias afetivas, apresentar distinções, ser produzida no interstício das subjetividades humanas.

A comida tem sido objeto de estudo da Antropologia da Alimentação e do campo Alimentação e Nutrição em Saúde Coletiva. (DAMATTA, 1986) Este último é resultante da aproximação de uma parte do campo da Alimentação e Nutrição com o da Saúde Coletiva, o que propiciou mudanças significativas nos investimentos científicos do escopo da área reconhecida apenas como Nutrição anteriormente. (BOSI; PRADO, 2011) As autoras entendem que as tensões paradigmáticas entre biológico e social perpassam a constituição deste campo, apontando assim elementos teóricos e inquietando a encarar comida e alimento, bem como alimentação e nutrição, por meio de abordagens que enfrentem tais dicotomias. Essa é uma discussão a ser empreendida oportunamente em investimentos futuros.

No que tange à discussão sobre comida de rua abordada acima, e mediante a analogia à ideia da assimetria moderna construída por Latour (1994), é possível supor que o homem constrói suas regras sociais de 
comensalidade, já que ele é o único autor da produção da sociedade, da condução de seu destino. Assim, as materialidades que possibilitam sua existência e seus modos de comer, as condições naturais que o forçam a estruturar seus processos adaptativos, diferentes em tempo e espaço, figuram como fatores que derivam relações entre natureza (alimento) e sociedade (comida), sem, contudo, avançar para um plano de imanência no qual as duas se coproduzem. O homem é o que possui agência na formação das comensalidades, sendo a comida um elemento inumano instrumental que veicula formas de sociabilidades humanas.

Latour (1994) busca desmitificar um dos pressupostos que legitima a ideia de modernidade constituído por meio do trabalho de purificação que permitiu acreditarmos ser possível decantar natureza e cultura (alimento/comida), afastando a existência dos híbridos de natureza-cultura que proliferam. No domínio alimentar, a dimensão biológica do alimento e a cultura alimentar corresponderiam a essas instâncias pretensamente separadas. No entanto, sobretudo as problemáticas cuja gênese incide no alimento-comida na atualidade, tais como as associadas ao uso de agroquímicos, aditivos alimentares, modificação genética e seus impactos na saúde, são constituídas no bojo das redes que acoplam tecnologia, ciência, ética, indústria, discursos, entre outros. Desse modo, o autor instiga a pensar tais instâncias mediante o híbrido alimento-comida, não uniforme e não pré-fabricado, que vai se hibridizando progressivamente no contato com outros elementos nas redes constituídas.

Sob outra ótica, DaMatta (1986) associa ainda a comida à perspectiva de identidade, algo que é reconhecido pela sociedade e imediatamente remete a um grupo ou implica alguma ideia. Sem espaço para problematizar teoricamente nesse ponto o constructo "identidade alimentar", essa premissa trazida pelo autor nos parece interessante para pensar como a comida de rua em sua constituição histórica é permeada por estereótipos. No imaginário coletivo, continuamente, ela é associada a contextos de necessidade e privação econômica e alimentar e à ausência de segurança alimentar, sendo vista como comida de pobre e um perigo à saúde. (CALLONI, 2013) 
A autora acima aponta elementos históricos que estariam relacionados à construção dessa imagem: a invenção da burguesia que implicou a associação da alimentação diretamente ao poder aquisitivo e a criação de restaurantes que inaugurou a marginalização progressiva da comida de rua como "comida para pobres". Desde os primórdios da industrialização, com as consequentes mudanças laborais e de tempo e espaço destinados às refeições, ela surge com o status de subalterna, consumida por pessoas pertencentes à classe social baixa, sendo confrontada pela possibilidade da burguesia em comer em seus confortáveis espaços privados e seguros.

No século XIX, a produção serializada de alimentos contribui para fortalecer esses estereótipos. Ademais, vai se consolidando, por meio da ciência da Nutrição, a imagem de que o alimento bom, seguro e saudável está confinado aos espaços internos e ambientes fechados (CALLONI, 2013), o que estaria distante das circunstâncias em que se insere a comida de rua. Os códigos dessa ciência ditam as normatizações de vigilância dos órgãos estatais instituindo normas inatingíveis pelas condições de possibilidades que dispõem os vendedores, ditos informais, de comida nas ruas.

Portanto, se a categoria sociológica "comida", proposta por DaMatta (1986), embute uma possibilidade de identidade, a comida de rua seria, ao menos em sua versão de informalidade, comida de pobre para pobre, suja, insegura, marginal, indesejada, não salubre. Comida que delineia uma distinção social tanto para quem a vende quanto para quem a come. Comida execrável que amontoa pobreza em volta de si nas ruas da cidade. Comida desprezível que ameaça a ordem de um urbanismo pretensamente linear. Comida abjeta, porque desautorizada pelos estatutos da ciência e do Estado.

Evidentemente, tal leitura não pretende universalizar o fenômeno, nem visa a negligenciar a polissemia que comporta o constructo, capturando-o em uma versão simplista. Ademais, a emergência de novos padrões de vida e consumo nas cidades, entre eles o crescimento do mercado formal da gastronomia nas ruas, por meio dosfood trucks, food parks, food malls, coloca a necessidade de pensarmos o fenômeno para além 
de sua ocorrência cotidiana e dos contextos da nomeada informalidade, salientando que esta não comporta sua associação instantânea com vidas que sofrem privação. Portanto, fundamentalmente, busca uma problematização acerca das representações e imagens sociais existentes em torno do objeto de estudo sobre o qual este ensaio se debruça.

\section{A COMIDA E A RUA}

O imaginário social em torno da comida de rua, sobretudo a perspectiva apontada anteriormente, pode ser tomado mediante uma interlocução teórica com os espaços da casa e da rua na sociedade brasileira, conforme explorados por DaMatta (1986). Tais espaços não se constituem meramente como lugares físicos, mas constructos sociais que possuem grande relevância nos mecanismos classificatórios da vida social e que se complementam mutuamente. São dois mundos que embutem moralidades, visões e valores diferenciados e pelos quais nossa sociabilidade navega.

A casa estaria imbricada a ideais de comunhão, daquilo que é comum, um agrupamento de uma só carne e sangue que protege e acolhe. É espaço seguro onde reinam a pessoalidade e as relações de estima mútua, sendo aí possível estabelecer uma convivialidade intensa. Assim, a comida de casa refletiria os simbolismos dessa categoria, sendo relacionada ao que é familiar, seleto, seguro, artesanal e saudável. (DAMATTA, 1986; DIEZ-GARCIA, 1997) Ademais, podemos inferir, a partir do seminal senso de comunidade constituído pela categoria "casa", que esta seria o espaço de excelência da comensalidade.

A rua relacionar-se-ia ao âmbito da desagregação, massa informe de pessoas indiferenciadas que ocupam as cidades, espaço onde as leis gerais e a autoridade incidem, homogeneizando os sujeitos, destituindo-os de suas singularidades. Há uma crueza no cotidiano da rua que advém da contrariedade das vontades, da impessoalidade que impõe, do perigo da exposição, do diferente que causa desconfiança, do movimento rápido, da mediação pelo trabalho. Por isso, sua associação à luta e à batalha, 
como se à rua coubesse as dimensões da vida mais contraditórias, duras e surpreendentes. (DAMATTA, 1986)

Em diálogo com essa exploração teórica, a comida de rua estaria associada à impessoalidade, ao perigo e risco alimentar, àquilo que não se sabe, ao malfazejo, sujo e, portanto, ameaçador. (DAMATTA, 1986; DIEZ-GARCIA, 1997) Poder-se-ia pensar que estar na rua contrariaria as aspirações de acesso à comida de casa, a qual denota pertencimento, afeição e estima. Além disso, essa perspectiva levaria a supor que o espaço da rua implicaria uma destituição da ritualização do comer e na desagregação da convivialidade mediada pela comida.

Entretanto, a rua brasileira enquanto uma questão teórica na envergadura das ciências sociais, explorada mediante as publicações acadêmicas por Frehse (2013), encerra distintas possibilidades de compreensão. Sua exploração revela que a interpretação da rua pelos autores tupiniquins se dá pelo confronto com o campo empírico e associa-se a quatro espaços marcados quanto ao uso social da rua pelos pedestres, a saber: desigualdade social; criatividade; oscilação casa e rua; e resistência. A autora ainda insere a perspectiva emergida de sua etnografia sobre a rua e os não transeuntes em São Paulo, a qual desponta como espaço público de pessoalidade moral. Por considerarmos que a abordagem anterior de DaMatta (1986) contemplou a categoria "oscilação entre casa e rua”, iremos nos deter brevemente nas outras perspectivas teóricas.

A rua enquanto desigualdade social está associada a situações de exclusão ou marginalidade, a depender da ênfase teórica do autor, e representa o maior agrupado de trabalhos acadêmicos. Em segundo plano, a rua enquanto espaço de criatividade embute o protagonismo de figuras como mendigos, malandros, camelôs, moradores de rua, entre outros. Em quarto lugar, surge a rua como espaço social de resistência revelando formas de sociabilidades conflituosas. Essa ótica comporta as relações tensas estabelecidas com o poderio do Estado, ditado mediante estratégias de institucionalização e de gentrificação, bem como confrontos com “'movimentações urbanas' supostamente excludentes”. (FREHSE, 2013, p. 5) 
Por meio de seu estudo autoetnográfico, realizado na Praça da Sé, em São Paulo, Frehse (2013) destitui a rua como um lugar de impessoalidade, concepção supostamente inferida frente à intensa movimentação humana na metrópole. Nele, a rua revela-se um espaço de pessoalidade moral, no qual critérios valorativos de bem e mal medeiam as interações sociais "focadamente desfocadas". Tais critérios fazem distinções entre pessoas nas ruas, sobretudo os intitulados não traseuntes, ou seja, aqueles que permanecem regularmente nas ruas, tais como os vendedores ambulantes de comida de rua. Algumas principais balizas surgem como mediadores classificatórios.

A autora pondera que as concepções acerca da rua nas ciências sociais exploradas anteriormente não deixam entrever como a pessoalidade moral constituída nas ruas interfere nos achados dos autores e na sua categorização. Ela atribui isso ao fato de que a problemática metodológica do papel das interações do pesquisador com os sujeitos no campo empírico e sua interface com a construção conceitual dos achados não são explicitadas durante a interpretação realizada.

Portanto, a rua comporta distintos arcabouços de apreensão quanto a seus usos sociais que interfaceiam com a exploração empírica e teórica acerca da comida de rua. Tal fenômeno pode ser investido pelas diferentes perspectivas acadêmicas colocadas acima. Porém, sua compreensão não prescinde de abeirar-se das práticas laborais e de comer que constroem a comida de rua diariamente nas cidades. No que tange àquelas, as abordagens da pessoalidade moral e resistência, além da oscilação casa e rua já discutida, fornecem elementos para refletir sobre o cotidiano conflituoso desenhado pela comida de rua informal, ilegal.

A interferência da pessoalidade moral abordada por Frehse (2013), no que tange à sociabilidade nas ruas, torna-se interessante para pensar como vão se conformando e afirmando técnicas de permanência nas ruas pelos vendedores ambulantes confinados ao rótulo de ilegais. Ilegais duplamente: por não ter licença de trabalho na rua e por não atingir o padrão de condições higiênico-sanitárias exigidas para afastar o risco alimentar e receber a outorga da Vigilância Sanitária. 
Anjaria (2016) contribui nesse sentido quando, estudando a venda ambulante de comida de rua em Mumbai, ao descortinar as relações cotidianas por meio de sua etnografia, consegue fazer emergir formas de governança urbana que não se limitam a uma racionalidade estatal de criminalidade, apoiada em uma relação de oposição entre funcionários do Estado versus ambulantes. Ao contrário, a condição de ilegalidade desses ambulantes permite a invenção de espaços de negociação nos quais outras formas de governança urbana legitimam a existência e manutenção dos vendedores no espaço público e são, muitas vezes, baseadas em relações de cooperação, familiaridade, negociação e vinculação entre tais atores.

O autor revela que a categoria "ilegalidade" ganha uma roupagem que não dicotomiza a experiência dos ambulantes em ilegal ou legal. Assim, desvenda gradações, estratificação de legalidade e ilegalidade desenhadas por meio dos acordos que vão se estabelecendo e se legitimando na interação entre funcionários municipais, empresários locais e ambulantes.

A dimensão da pessoalidade moral embute ainda a possibilidade de pensarmos a comensalidade no espaço da rua para além da perspectiva da desagregação da convivialidade. Além disso, a rua, na perspectiva de Latour (1994), associa-se a uma trama mais ampla de elementos humanos e inumanos em interação.

\section{A CIDADE E O CORPO}

A comida de rua, enquanto objeto de estudo aqui interpelado, nos provoca a refletir sobre a cidade, os usos de seus espaços públicos e seus modos de experimentação cotidiana pelos citadinos. Assim, importa pensar as mútuas imbricações entre cidade e corpos que a percorrem e a constroem.

A cidade, operada sob a ótica do capital financeiro e aparato midiático, é apresentada como uma imagem mercadoria que visa a mediar as relações de uso e sociabilidade do espaço a fim de favorecer fluxos da economia planetária. Desse modo, busca-se construir uma urbe "espetáculo" que traça distinções nas possibilidades de sua experimentação 
e consumo, por meio de recursos imagéticos e discursos materializados em projetos de requalificação e revitalização, particularmente dos centros históricos, nos quais a disciplina urbanística tem papel fundamental. Nesse contexto, a arquitetura possibilita a constituição de cenografias urbanas que tendem a minorar a magnitude das sociabilidades no espaço público, ou ainda transformar as anteriormente existentes, em favor de sua apropriação mercantil e especulativa. (LIMA, 2004; TEOBALDO, 2010)

As estratégias utilizadas constroem representações sobre a cidade que buscam anuviar os conflitos e dissensões presentes, desconsiderando, ou incluindo de forma excludente, as óticas divergentes daquela pretendida, buscando promover a pacificação dos espaços citadinos, sobretudo os públicos. Os antigos usos do espaço revitalizado vão sendo deslegitimados, provocando modificações na ocupação e no perfil de seus usuários, bem como na distribuição espacial de poder. (LIMA, 2004; TEOBALDO, 2010) De tal modo, o discurso da desordem urbana é usado a serviço de um tipo de desenvolvimento que procura invisibilizar as necessidades e contestação do uso do espaço público pelos menos abastados, a exemplo dos vendedores informais de comida de rua.

A cidade espetáculo, projetada e pré-instituída, convoca à contemplação e a uma experimentação teatralizada da urbe, nas quais os corpos, mesmo não destituídos de sua capacidade de afetação, são provocados a limitar-se a vivenciá-la por intermédio de experiências pré-fabricadas associadas à constituição de desejos homogeneizados e hegemônicos. (JACQUES, 2012; TEOBALDO, 2010)

Contudo, a espetacularização das cidades e os métodos dominantes de planificação urbana não se dão de forma totalizante. A totalização e a colonização dos espaços são muito mais uma aspiração do que uma realidade de fato. Assim também o é a pretensa esterilização das diferentes experiências na urbe. É nesse sentido que importa apreender a cidade mediante abordagens que produzam resistência a esses modelos e representações.

Paola Berenstein Jacques, em seu livro intitulado Elogio aos errantes (2012), traz pressupostos teórico-metodológicos interessantes para 
a compreensão da cidade por meio dessa resistência. A partir de uma exploração teórica na história do urbanismo e diálogo com diversos autores, ela propõe que as cidades sejam apreendidas mediante os modos como elas são experimentadas e produzidas pelos corpos. Assim, sugere o estudo da cidade incorporada.

Problematizando a questão da experiência na cidade e seu relativo processo de desintensificação e homogeneização intencionado pelos modelos hegemônicos, ela alega a sua sobrevivência. De tal modo, instiga a sermos errantes, tanto na experimentação da cidade quanto na sua investigação, compondo, com isso, formas de resistência. Nesse sentido, o errante seria "aquele que busca um estado de corpo errante, que experimenta a cidade através das errâncias, que se preocupa mais com as práticas, ações e percursos, do que com as representações, planificações ou projeções”. (JACQUES, 2012, p. 24)

Ganha relevância em sua obra o que ela chama de o Outro urbano, o diferente que provoca fissuras, que desdenha os arquétipos da cidade espetáculo. Ao invés de regiões pomposas, eles habitam áreas anódinas compondo uma cidade dinâmica que pulsa ante as brechas da cidade-imagem. Na sua invisibilidade, reinventam o cotidiano, construindo estratégias de sobrevivência e de investidura do espaço público, dissonando dos pretensos consensos incutidos pelos projetos urbanísticos. O Outro urbano é notadamente associado àqueles que convivem nas ruas, como moradores de rua e ambulantes, e para os quais a assepsia especulativa da revitalização lança seus primeiros tentáculos. Destarte, os errantes urbanos subsistem e erram mediante sua obscuridade.

Errar, portanto, pressupõe um movimento que vai de encontro à alteridade, comportando os vários outros e diferentes que perfazem a cidade, como um território dinâmico de experiências. Ademais, importa também a construção de narrativas errantes que comuniquem tais experiências. (JACQUES, 2012)

Para os errantes, a cidade não é puramente imagem ou o cenário em que a vida acontece, mas é cidade vivida e inscrita no corpo por meio da experiência. É incorporada que ela resiste à sua modelagem pelos 
projetos universalizantes, uma vez que a mera existência de tais corporalidades vilipendia e delata as tentativas de captura e domesticação. Em seu percurso, os corpos experimentam a cidade ao mesmo tempo em que a constroem. Há, assim, uma dinâmica ininterrupta de coprodução entre corpos e cidade. (JACQUES, 2012)

Nessa perspectiva, a autora insere o constructo "corpografia urbana" como a expressão, mediante corporalidades, resultante das distintas interações que o corpo experimenta na urbe. A cidade agencia compostos de circunstâncias lidas como interativas pelo corpo, o qual as processa na medida em que constrói suas inter-relações com outros corpos, objetos, ideias, entre outros, constituindo suas corpografias. Em vista disso, as práticas de errância possibilitariam o processamento de experiências corporais mais complexas e, consequentemente, corpografias urbanas mais complexas. Assim, o estudo dessas corpografias poderia servir a outras formas de apreensão do espaço urbano, que, por sua vez, forneceria subsídios para a elaboração de outras formas de intervenção nas cidades. (JACQUES, 2008)

Segundo Jacques (2012, p. 301),

As corpografias permitem compreender não só as configurações de corporalidade como memórias corporais resultantes da experiência de espacialidade, mas também as configurações urbanas como memórias espacializadas dos corpos que as experimentaram.

Em vista disso, podem constituir um interessante contraponto de apreensão da cidade face à sua espetacularização.

A não conformidade da presença dos vendedores ambulantes de comida na rua aos planos de desenvolvimento urbanístico no capitalismo avançado e à ótica das políticas oficiais delineia relações sociais conflituosas entre estes e o poder público, que tensiona constantemente uma possibilidade virtual de varredura da venda da comida nas ruas que não se efetua de fato e de vez. E, por mais que a repressão estatal materialize-se em alguns contextos, por meio da ação da polícia ou do "Rapa", a ocupação do espaço público pelos ilegais se refaz, o que remete ao domínio 
das práticas de errância pela cidade, constituindo corpografias capazes de fornecer subsídios para uma leitura da cidade por meio de suas apropriações resistentes e desviantes daquelas pretendidas pelos projetos urbanísticos hegemônicos.

Por meio dessa discussão, pode-se inferir que a perspectiva de coprodução entre corpo e cidade faz interface com os pressupostos teóricos de Latour (1994, 2000). Ademais, a concepção de corpo debatida pelo autor, vinculada a ideias de movimento e aprendizagem não estável, pode contribuir para pensar as imbricações entre essas categorias. (LATOUR, 2007)

Corpo, para Latour (2007, p. 39), envolve o aprendizado incessante de ser mobilizado, afetado, efetuado por outros elementos humanos e inumanos. Daí, a incongruência de defini-lo diretamente, já que se trata de um processo de sensibilizá-lo para o que são os outros elementos. Corpo como "[...] aquilo que deixa uma trajetória dinâmica através da qual aprendemos a registrar e a ser sensíveis àquilo de que é feito o mundo". O processo contínuo de afetação por múltiplos elementos possibilita uma ampliação da possibilidade de descrição do que é o corpo, essa superfície que tece um itinerário dinâmico por meio do qual nos tornamos mais sensíveis ao mundo.

Latour (2007) convoca a pensarmos em corpo para além das partes inerentes ao corpo humano, incorporando as partes coextensivas ao corpo, "contrapartidas do mundo" que têm a capacidade de convocar à afetação e inscreverem-se de novas formas, provocando progressivas habilidades de distinções: "Adquirir um corpo é um empreendimento progressivo que produz simultaneamente um meio sensorial e um mundo sensível". As "contrapartidas do mundo" compõem o que é ter um corpo, sensibilizando-o a diferenças que, antes não registradas, agora permitem distinções mais sutis. (LATOUR, 2007, p. 40)

A cidade como algo simultaneamente experimentado e construído pelo corpo, bem como o corpo que se forma a partir da interação com as diferenças, remete à ideia das agências humanas e inumanas componentes das redes de inter-relações que efetuam realidades situadas. Em vista disso é que interessam os corpos e outros elementos que delineiam os contextos nos 
quais as práticas laborais e de comer na rua se produzem. Nesse contexto, a comida de rua se coloca como elemento inumano que agencia a formação de corpos, seja de seus vendedores e comedores ou outros. Por sua vez, a rua e a cidade comportam a expressão mais rica e evidente das diferenças potencialmente produtoras das redes de inter-relação.

Ademais, as práticas dos ambulantes de comida de rua como errantes, bem com suas narrativas errantes, aludem à potência que as forças "menores" e heterogêneas têm de possibilitar a apreensão da apropriação do espaço público mediante o que está efetuando realidades naquele contexto. Desse modo, pode possibilitar sua compreensão para além dos enunciados hegemônicos da cidade espetáculo que intenciona construir os elementos abjetos, nesse caso comida de rua e/ou seus vendedores, visando a materializar a ocupação desigual de poder no espaço urbano.

As práticas errantes dos vendedores ambulantes de comida de rua possuem, assim, elementos políticos subversivos ao delinearem estratégias de resistência às tentativas de totalização da experiência urbana e de apropriação do espaço público, embutindo potenciais meios de enfretamento das forças déspotas no uso da cidade. Desde uma apropriação marginal e opaca do espaço público e de seu caráter de subalternidade frente ao modelo de cidade espetáculo, as corporalidades desses ambulantes persistem na construção cotidiana da cidade, enquanto a cidade entranha-se em seus corpos as produzindo.

\section{COMENSALIDADES ATUADAS NA RUA}

A comensalidade, grosso modo, está associada à conviviabilidade de humanos em torno da comida. Fischler (2011) problematiza tal acepção considerando-a restrita. Assim, aponta para a incorporação da marcação de distinções que delimitam incluídos e excluídos, dos domínios da partilha, cooperação e pertencimento, da existência das gradações de dependência e hierarquia entre comensais humanos. Atenta ainda para a significância da normalização do comer no processo de transmissão cultural, de habilidades sociais. Nestes termos, a comensalidade forneceria, 
nas palavras do autor, um script para muitos ou para a maioria dos acontecimentos alimentares humanos. Tal script poderia ser pensado como produto de um saber coletivo e compartilhado, que o homem vai tecendo, sendo tecido e aprendendo a comer.

A comensalidade, então, estaria associada às ações humanas delineadas em volta da necessidade biológica da alimentação. Numa discussão sobre essa questão, Simmel (2004) defende que a própria necessidade fisiológica de comer, partilhada entre todos os homens, produziu espaço para o sobrepujamento do egoísmo materialista do ato alimentar ao demandar encontros derivados dela. Assim, somente as normatizações constituídas por essa socialização seriam capazes de superar a finalidade material desse ato. Tal abordagem comporta uma espécie de oposição estabelecida entre dimensão natural e social do comer, associando-o a uma transformação linear de uma para a outra, atingida pela forma social da refeição.

Essa breve incursão, mediante autores seminais que versam sobre o comer no âmbito das relações sociais humanas, contribui para problematizar o modo como a comensalidade é tratada em boa parte da produção acadêmica. Ela tem sido pensada hegemonicamente a partir da ótica da função social da comida, privilegiando tradicionalmente a dimensão simbólica da alimentação tecida pela humanidade. Assim, a própria tentativa de marcação das características desse constructo comporta a acepção da partição do mundo em natural e material, produzida no bojo das ciências e tão criticada por Latour (1994).

Além disso, não é tão incomum a presença de um subjacente apelo saudosista ao resgate da comensalidade tradicional característica do âmbito doméstico e familiar. Tal apelo está associado à crescente individualização do comer que derivaria um esgarçamento das refeições, repercutindo no âmbito da saúde humana. Essa abordagem saudosista tem inquietado os cientistas sociais a questionarem os fundamentos ideológicos e morais que a alimentam. (FISCHLER, 2011) Adicionalmente, as realidades efetuadas pelos distintos elementos heterogêneos em interação nas cidades, produzindo diversificados e novos modos de comer, põem em questão o soerguimento de modelos ideais. 
Deriva-se da discussão acima a inferência de que a comensalidade voltar-se-ia ao mundo simbólico erigido em torno da alimentação, constituído exclusivamente pelos humanos e a ser abordado pelas ciências sociais. A centralidade da ação humana nessa concepção seria uma repercussão do trabalho de "purificação" associado à ideia de modernidade, já discutida no primeiro tópico. (LATOUR, 1994) Assim, as materialidades vinculadas à sua produção seriam concebidas como variáveis-palco das relações entre homem e natureza, uma dimensão da realidade a ser explorada pelas ciências naturais.

As proposições de Latour (1994) desafiam o monopólio da ação intencional humana na produção de comensalidades, uma vez que nos levam a pensar a comida como um agente inumano. Assim, ela não é concebida como mera mercadoria, um produto de consumo, um objeto da natureza dominado e explorado pelo homem, um conjunto de nutrientes passíveis de assimilação pelo corpo ou um veículo de uma série de simbolismos e representações. Mas, como agente inumano, promove alterações no curso das práticas, com o potencial de influenciar, interromper, possibilitar, estimular, autorizar, entre outros, as ações produzidas. Desse modo, tem agência na produção de realidades operadas pelas interações ocorridas entre diferentes atores nas trajetórias de ação.

A compreensão de que diversos elementos, humanos e inumanos, agenciam as práticas que produzem realidades tangencia a problematização de comensalidade. Ao invés de esta ser constituída mediante processos de socialização oriundos da dimensão social erigida apenas pelos humanos, as comensalidades podem ser pensadas mediante práticas de comer produzidas por meio de inter-relações entre elementos heterogêneos em contextos situados. Aqui, corpos, comida, rua e cidade estão lançados a possibilidades de conexões operadas nas redes.

Desse modo, poder-se-ia questionar que a própria palavra "comensalidade" não caberia na delineação teórica adotada neste ensaio, ao estar associada, grosso modo, a uma espécie de amálgama que uniria os humanos ao comer - aqui posto como verbo -, seja o espaço, a comida, os modos à mesa, as normas, entre outros, moldando suas experiências 
com a alimentação. Porém, tal expressão comporta uma possibilidade de compreensão da dinâmica de interação entre "entes", ou melhor dizendo, outros diferentes, ao embutir a ideia de encontro, daquilo que é posto em conexão, que se atualiza na ação. Dentre esses outros, essa interação não prescindiria do híbrido alimento-comida.

Nesse sentido, as comensalidades não se encerram em um substantivo abstrato, mas são em ação. São produzidas na e pelas práticas; não se dão de modo anterior a elas. Não são modelo a ser perseguido ou representação da realidade, mas distintas comensalidades produzidas mediante os diversos modos como elas são efetuadas nos contextos. Deriva daí a compreensão das comensalidades atuadas.

Na dinâmica da produção de comensalidades atuadas, interessa pensar os diferentes elementos humanos e inumanos em interação. Pessoas, cenoura, calorias, nutrientes, mídia, animais, conhecimento científico, discursos, tecnologias digitais, fisiologia, agroquímicos, consumismo, questões éticas, entre outros elementos - mas não necessariamente todos ou apenas esses - que estejam efetuando comensalidades nos contextos.

O descentramento do monopólio humano no curso das ações provoca, nas realidades produzidas pelas práticas nas quais pessoas e comida são agentes em interação, outras possibilidades de compreensão da interseção que superem a oposição: homem como sujeito e alimento-comida como objeto; associada a uma perspectiva racionalista e nutricional da alimentação. A provocação de Latour (1994) em torno da quebra ou minimização das hierarquias entre agências humanas e inumanas põe homem e alimento-comida num diálogo mais aplainado, que permitiria desvelar com maior nitidez os híbridos de natureza-cultura que proliferam nesse âmbito. Ademais, os interagenciamentos desses elementos estendem as comensalidades para uma dinâmica de interação que embute uma abertura contínua de corpos e alimento-comida à afetação pelas diferenças apresentadas.

Assim, a rua entra como elemento e como produto de uma conjugação de elementos que se colocam em interação na produção das comensalidades atuadas. Ela comporta uma miríade complexa de outros 
diferentes, humanos e inumanos, que expressam com mais evidência a heterogeneidade das redes de inter-relações que efetuam os distintos modos de produção das comensalidades em contextos situados. Isto posto, tal visão distancia-se da concepção da rua como espaço privilegiado de desintegração da comensalidade, de destituição da ritualização do comer. Por outro lado, sua exploração pode iluminar a busca de abordagens que tangenciem complexidades introduzidas pelas distintas práticas do comer na cidade.

Desse modo é que pensar as comensalidades atuadas na rua sintetiza uma tentativa inicial de efetuar práticas científicas que não dicotomizem instâncias mutuamente imbricadas na produção do objeto de análise "comida de rua".

\section{CONSIDERAÇÕES FINAIS}

No presente ensaio buscamos problematizar o objeto "comida de rua" por meio de uma incursão em categorias teóricas que se associam ao seu delineamento, tais como comida, casa, rua, corpo e cidade. Ademais, convocamos autores da TAR para inserir pressupostos teórico-metodológicos que pudessem contribuir no sobrepujamento da abordagem de tais categorias como instâncias decantadas na produção do conhecimento. Esse entrecruzamento permitiu vislumbrarmos as comensalidades atuadas na rua como uma possibilidade da interpelação da comida de rua com potencial para enfrentar tal desafio.

No percurso, pudemos concluir que a rua, a proposição da cidade espetáculo e acepção, aventada por nós, de "alimento de rua" trazem desafios para a noção tradicional de comensalidade, erigida a partir somente da ação humana no mundo. Por outro lado, Bruno Latour, com sua ideia de agências humanas e inumanas e as redes de inter-relações, provoca a pensar a comensalidade para além do singular e do âmbito humano. Ademais, incita a explorar alimento-comida como agente inumano capaz de engendrar alterações no curso da ação que, em sua proposta, é movimentada por elementos heterogêneos. 
A comida de rua e as comensalidades atuadas na rua são fenômenos que se associam à discussão conceitual sobre cidade que, neste escrito, afilia-se à ideia de cidade produzida a partir da experiência cotidiana (JACQUES, 2012), mobilizada pelas materialidades e humanidades que se interagenciam operando realidades. Tal acepção, aqui colocada, busca enfatizar uma cidade efetuada por meio das práticas de vendedores ambulantes de comida de rua considerados informais, bem como de comedores dessa comida. Intentamos ressaltar, em parte do texto, sobretudo as questões envolvidas no uso do espaço público pelos trabalhadores, desafiando o uso déspota desse espaço legitimado pelo projeto da cidade espetáculo pacificada.

Na contramão do silenciamento das diferenças pretendido pelo projeto espetacular de cidade, a exploração teórica inicial, possibilitada por este ensaio, mostrou que a "comida de rua" enquanto objeto de estudo comporta um conjunto de distintas problemáticas que pululam na cidade. Desse modo, um desafio é produzir ângulos de análise que incorporem as diferenças, as alteridades que promovem resistências, como tentativa de escapar da captura da comida de rua como uma categoria aprioristicamente dada.

\section{REFERÊNCIAS}

ANJARIA, J. S. The Slow Boil: street food, rights and public space in Mumbai. Stanford, CA: Stanford University Press, 2016.

BARKER, S. F.; AMOAH, P.; DRECHSEL, P. A probabilistic model of gastroenteritis risks associated with consumption of street food salads in Kumasi, Ghana: evaluation of methods to estimate pathogen dose from water, produce or food quality. The Science ofthe Total Environment, Amsterdã, v. 487, p. 130-42, 2014.

BEZERRA, A. C. D.; MANCUSO, A. M. C.; HEITZ, S. J. J. Alimento de rua na agenda nacional de segurança alimentar e nutricional: um ensaio para a qualificação sanitária no Brasil. Ciência \& Saúde Coletiva, Rio de Janeiro, v. 19, n. 5, p. 1489-1494, 2014. 
BOSI, M.L.M.; PRADO, S.D. Alimentação e nutrição em saúde coletiva: constituição, contornos e estatuto científico. Ciência \& Saúde Coletiva, Rio de Janeiro, v. 16, n. 1, p. 7-17, jan. 2011.

CALLONI, M.Street food on the move: a socio-philosophical approach. Journal of Science of Food and Agriculture, Hoboken, v. 93, n. 14, Nov. 2013.

DAMATTA, R. O faz o Brasil, Brasil? Rio de Janeiro: Rocco, 1986.

DIEZ-GARCIA, R. W. Práticas e comportamento alimentar no meio urbano: um estudo no centro da cidade de São Paulo. Cadernos de Saúde Pública, Rio de Janeiro, v. 13, n. 3, p. 455-467, 1997.

FISCHLER, C. Commensality, society and culture. Social Science Information, Thousand Oaks, v. 50, n. 3-4, p. 528-548, 2011.

FOOD AND AGRICULTURE ORGANIZATION OF THE UNITED NATIONS - FAO. Street foods (FAO food and nutritionpaper): alimentation de rue (Étude FAO alimentation et nutrition): Alimentos que se venden en la vía pública (Estudio FAO alimentación y nutrición. Roma: FAO, 1997. Disponível em: http://www.fao.org/docrep/W4128T/W4128T00.HTM. Acesso em: 12 nov. 2015.

FREHSE, F. A rua no Brasil em questão (etnográfica). Anuário Antropológico, Brasília, DF, p. 99-129, 2013.

JACQUES, P. B. Corpografias urbanas. Arquitextos, São Paulo, ano 8, n. 093.0, fev. 2008

JACQUES, P. B. Elogio aos errantes. Salvador: Edufba, 2012.

JOO, N.; LEE, B.; YOON, J. Importance-satisfaction analysis of street food sanitation and choice factor in Korea and Taiwan. Nutrition Research and Practice, v. 9, n. 3, p. 296-303, 2015.

LATOUR, B. Ciência em ação: como seguir cientistas e engenheiros sociedade afora. São Paulo: Ed. Unesp, 2000.

LATOUR, B. Como falar do corpo? A dimensão normativa dos estudos sobre a ciência. In: NUNES, J. A.; ROQUE, R. (org.). Objetos impuros: experiências em estudos sociais da ciência. Porto: Afrontamento, 2007. p. 40-61.

LATOUR, B. Jamais fomos modernos: ensaio de antropologia simétrica. Rio de Janeiro: Editora 34, 1994. 
LATOUR, B. Reagregando o social: uma introdução à teoria do ator-rede. Salvador: Edufba; Bauru, SP: Edusc, 2012.

LEROI-GOURHAN, A. O gesto e a palavra: 2 - a memória e os ritmos. Lisboa: Edições 70, 1975. (Coleção Perspectiva do Homem, v. 16).

LIMA, E. F. W. Configurações urbanas cenográficas e o fenômeno da "gentrificação". Arquitextos, São Paulo, ano 4, n. 046.03, mar. 2004.

LIMA, V. C. As dietas africanas. In: FERNANDES, C. (org.). Viagem gastronômica através do Brasil. 8. ed. São Paulo: SENAC: Estúdio Sonia Robato, 2007.

MARRES, N. Testing powers of engagement: green living experiments, the ontological turn and the undoability of involvement. European Journal of Social Theory, Thousand Oaks, v. 12, n. 1, p. 117-133, 2009.

MOL, A. The body multiple: ontology in medical practice. Durham: Duke University Press, 2002.

OKOJIE P. W; ISAH, E. C. Sanitary conditions of food vending sites and food handling practices of street food vendors in Benin City, Nigeria: implication for food hygiene and safety. Journal of Environment and Public Health, Londres, p. 1-6, 2014.

SIMMEL, G. Sociologia da refeição. Estudos Históricos, Rio de Janeiro, n. 33, p. 159-166, jan./jun. 2004.

SOUZA, G. et al. Comida de rua: avaliação das condições higiênico-sanitárias de manipuladores de alimentos. Ciência \& Saúde Coletiva, Rio de Janeiro, v. 20, n. 8, p. 2329-2338, 2015.

TEOBALDO, I. N. C. A cidade espetáculo: efeito da globalização. Sociologia: Revista do Departamento de Sociologia da FLUP, Porto, v. XX, p. 137-148, 2010.

VIDAL JÚNIOR, P. O.; CARDOSO, R. C. V.; ASSUNCAO, L. S. O comércio e a segurança de ovos de codorna em praias de Salvador (BA): um estudo na perspectiva do trabalho infantil. Revista de Nutrição, Campinas, v. 26, n. 4, p. 419-429, jul./ago. 2013. 



\section{Le style veggie comment l'ascétisme est-il devenu cool}

MARIANNE CELKA

\section{INTRODUCTION}

Depuis quelques années maintenant, dans les grandes villes d'Europe et d'Amérique, en France comme au Brésil, nous voyons fleurir de nombreuses enseignes, restaurants, épiceries, boutiques cosmétiques et boutiques de mode, certifiés "sans cruauté". Le style veggie s'est répandu comme une nouvelle manière d'être tendance. À l'origine pourtant, le veganisme s'est construit comme un mode de vie ascétique, réservé à une élite militante dans le sens où il impliquait une connaissance assez complexe et raffinée des questions relatives à la condition animale. Une élite parce que ce mode de vie était difficile à appliquer, difficile à vivre 
au quotidien et qu'il n’etait effectivement partagé que par une poignée d'individus aux ambitions morales supérieures.

Les modalités de communication des grandes organisations non-gouvernementales (Peta ou Sea Shepherd) d'une part, accompagnées de leur cortège de célébrités, et les associations nationales ou internationales pour la libération animale d'autre part, en divulguant les atrocités qui se cachent derrière les murs des abattoirs en particulier mais aussi dans tous les domaines de l'exploitation animale, ont participé à la popularisation du mode de vie vegan. Toutefois, dans l'expérience urbaine, où se joue une lutte discrète mais certaine pour le pouvoir non-institué, le mode de vie ascétique du veganisme s'est métamorphosé en une attitude cool. Le veggie est devenu une manière hype et éthique de consommer. De quelle sensibilité collective ce style est-il l'expression? Que dit-il sur nos pratiques urbaines contemporaines?

C'est de ce trajet qui va de l'ascétisme marginal jusqu'au style veggie ainsi que des questions que ce trajet implique et soulève du point de vue du pouvoir, de la biopolitique (Michel Foucault), des logiques d'autocontrainte et de désublimation répressive (Herbert Marcuse) que nous traiterons. Il s'agira d'embrasser la dynamique qui a vu le succès d'une pratique ascétique devenue cool via les ressorts de la consommation et du spectacle mais aussi de révéler dans quelle mesure le style en question est porteur de modalités d'autorégulation des mœurs et des corps dans l'agir quotidien des métropoles contemporaines.

\section{LE STYLE VEGGIE}

Si l'on souhaite comprendre objectivement les motivations et les significations subjectives qui soutiennent et impulsent laction sociale animaliste - et ce au sens des préceptes énoncés par la sociologie compréhensive -, il nous faudra tenter de saisir ce qui, dans les représentations collectives, concernent le consensus social d'une part mais aussi ce qui concernent les idéaux de "minorités actives". (MOSCOVICI, 1991) Il nous faudra saisir ce qui fait sens, fournit des significations 
collectivement partagées et participent à la construction sociale des identités dans le cadre des métropoles contemporaines. Du point de vue des sous-cultures et des contre-cultures, il apparaît nécessaire de faire appel aux enseignements théoriques élaborés par les cultural studies, lesquelles ont su mettre le doigt sur les manières dont les groupes sociaux minoritaires et contestataires expriment, dans l'expérience urbaine, via le style qui les caractérise, une vision du monde alternative et concurrente. Puisque nous posons au préalable le fait constaté que les acteurs sociaux qui se définissent animalistes (antispécistes et vegans) se manifestent dans l'espace social comme porteurs d'une culture alternative, il serait pertinent de les interroger sous le prisme des styles de vie.

C'est en référence au socio-sémiologue britannique Dick Hebdige (2008, p. 211) que nous pouvons considérer la dynamique au cœur des sous-cultures, et du style qui les exprime, de la manière suivante:

le style d'une sous-culture donnée est toujours lourd de signification. Ses métamorphoses sont contre nature, elles interrompent le processus de normalisation. De ce point de vue, elles sont autant de gestes en direction d'un discours qui scandalise la majorité silencieuse, qui conteste le principe d'unité et de cohésion, qui contredit le mythe du consensus.

Le consensus social, la cohésion sociale au sens d'Émile Durkheim, est maintenu par un ensemble de croyances et de pratiques qui sont partagés - en moyenne - par l'ensemble des membres d'une société. C'est à partir du contexte postindustriel que les métarécits qui soutenaient la modernité et permettait sa cohésion sociale commencent à souffrir d'une certaine déliquescence en termes d'adhésion collective.

Que ce soit dans les analyses de Jean-François Lyotard (1979) ou celles d'Alvin Toffler (1971), l’on note quà partir des années 1960-1970, le consensus social endure une lente dégradation de ses structures narratives et coercitives tant du point de vue des images que des récits qui maintiennent serrées les mailles du tissu social. Ainsi, c'est l'occasion de repérer léclosion d'une multitude de micros-récits portés par des petits groupes sociaux qui tantôt s'entrecroisent, s'entrechoquent, se complètent ou 
sopposent dans une ambiance sociale renouvelée. Le mythe du progrès technique, scientifique et moral, s'est trouvé mis à mal par une succession de ce que Bertrand Vidal (2014) appelle des "événements-catastrophes" - catastrophes industrielles et militaires, naturelles et sociales, initiatrices de peurs collectives: danger nucléaire, dérèglement climatique, attentat terroriste etc. -, qui ont fini par rendre sa structure narrative caduque. Alors même si l'on peut dire que "la catastrophe, parce qu'à la fois possibilité inouïe de palingenèse et expérience des limites de l'expérience, nous attire" (VIDAL, 2014, p. 79), ces événements paroxystiques ont contribué à la déliquescence des mythes modernes.

Parmi les discours qui se sont font entendre depuis la chute des " $m e ́-$ tarécits" (LYOTARD, 1979), l'animalisme contemporain a résonné comme millénarisme et appel au Grand Soir du social par l'entremise de laquelle la collectivité pourrait se laver des souillures et des abominations passées. Le péché originel dénoncé par l'antispécisme et le veganisme c'est celui de la chair. L'animal, pris dans les courroies destructrices de l'industrie alimentaire, cosmétique, médicale et ludique est devenu le martyr muet des temps postmodernes. Ce que les militants vegans nomment "carnisme" (2016) serait l'idéologie consensuelle qui domine les sociétés occidentales - voire mondiales - et qui se définie par le soutient, la justification mais aussi l'encouragement de la consommation de la chair animale par les humains. Dès lors, pour les tenants de la contre-culture vegane, il s'agit de se dresser contre l'idéologie dominante par l'expression d'un refus originel, celui de la consommation animale que ce soit pour se nourrir, se couvrir, se soigner ou se divertir.

Refus non pas tant d'un réel cruel qui est précisément dénoncé et diffusé à coup d'images-choc par nombre d'associations pour la libération animale, mais refus plutôt de la métaphore sociale qui consiste à traduire la chair animale en viande sous les artifices nécessaires de ce que l'on nomme gastronomie ou arts de la table. Refus de ce que les militants animalistes considèrent comme un mensonge sociétal qui nous maintiendrait - sans qu'on en ait toujours conscience - dans une posture dominatrice et illégitime de l'homme sur l'animal. C'est cela que 
dénonce le veganisme et c'est contre cela qu'il s'impose dans les moindres aspects d'une vie quotidienne. Devenue ostentatoire, le style veggie se déploie dans les médias, sur les réseaux électroniques et dans le cœur de ville comme la vitrine d'une éthique érigée en un système de valeurs non-négociables.

\section{UNE MODALITE CONSOMAMTOIRE}

Le veganisme ne se réduit pas en effet à la promotion d'un régime alimentaire spécifiquement végétalien mais par un mode de vie qui se déploie comme fait social total (MAUSS, 1997), dans la mesure où tous les domaines de la vie des hommes en société, dans chacun de leurs interstices, sont concernés par un ensemble d'impératifs et d'interdits sociaux. Depuis les années 1960 au cours desquelles on a assisté à la multiplication des cellules et comités de libération animale (ALF, ARM etc.) jusquà la popularisation du veganisme à travers les organisations non-gouvernementales (Peta, Sea Shepherd) et associations animalistes (L214, 269 Life, Vegan Impact etc.), la contre-culture en question et le style qu'il porte ont envahi les métropoles du monde entier. Aucun pays du nord au sud, de l'est à l'ouest, n'est aujourd'hui exempt de son petit "veggietown", ou à tout le moins de quelques boutiques, restaurants, épiceries certifiées "sans cruauté". Ce style, marginal au départ, assez discret dans sa manifestation puisqu'il nécessitait de développer un regard d'expert et se déployait activement selon les logiques de la clandestinité, a su trouvé les voies d'un succès populaire. Il est devenu une modalité consommatoire incontournable pour tous les entrepreneurs, des cosmétiques biologiques aux grandes firmes automobiles, qui tentent d'ouvrir de nouvelles voies dans le marché. Les plus infimes particules de la vie quotidienne se déclinent désormais selon le style veggie.

Que les choses soient claires, pour ce qui concerne la contre-culture animaliste et la lutte qu'elle a entrepris jadis, "le carburant n'est plus le militantisme". Pour Théo Ribeton, auteur de V comme Vegan, dorénavant c'est la consommation. La contestation sociale se serait-elle fait prendre 
au piège de la société marchande? Être différent, porter des valeurs alternatives et potentiellement révolutionnaires s'exprime aujourd'hui par la manière dont on remplit son frigo, ses armoires, la manière dont on fait son shopping. Cela fait quelques décennies déjà que les penseurs des contre-cultures ont compris que "Les rébellions culturelles ne menacent pas le système, elles sont le système". (HEATH; POTTER, 2005, p. 11) C'est à partir des années 2000-2010 que l’on peut repérer ce glissement significatif qui va d'une logique communautaire voire tribale (MAFFESOLI, 2000) - celle des premières cellules de libération dont les liens de solidarité reposaient précisément sur la chaleur d'une clandestinité assumée et sur l'expérience de faire partie d'un groupe minoritaire et subversif - à une logique sociétaire caractéristique des grandes métropoles modernes, aux liens plus froids et réifiés. De l'affectivité qui émanait des cellules radicales et parfois violentes engagées dans la lutte animaliste, l'on est passé à une foule de partisans arborant fièrement leurs t-shirts flanqués du slogan "I'm Vegan". Être vegan à l'ère des réseaux sociaux, consiste principalement à liker, partager, twitter, instagramer quelques mots, quelques images plus ou moins liées à la lutte originelle, cela consiste en définitive à se mettre en scène via les logiques spectaculaires des vitrines électroniques.

La contre-culture vegane a réussi et cela signifie dans le même temps qu'elle se consomme et même se consume. C'est dorénavant le sens du style veggie qui, une fois sorti des ombres chargées des soupçons relatifs à toute hétérogénéité du corps social, peut s'associer à nombre d'autres modalités consommatoires pour produire des combinaisons inédites. On peut dès lors imaginer des gammes de produits industrialisés certifiés "gluten \& cruelty free". Cette révolte consommée doit être appréciée dans sa double dimension, celle d'un style comme moteur de production capitaliste (dans lélaboration toujours croissante de produits sériés veggies) et celle qui consiste à consommer sa propre vie de vegan (la mise en scène d'un Soi veggie). D'une part la contestation qui résidait au cœur de la contre-culture vegane s'est transformée en modalité de consommation et, au lieu de perturber le système, sert de de moteur 
pour la production capitaliste et industrielle ; d'autre part, les réseaux électroniques encouragent la mise en scène ou "présentation de Soi" au sens d'Erving Goffman (1973), à travers nombre de hashtags "maviedevegan”. Une double consommation donc, matérielle d'abord, qui trouve autant de réceptacles qu'il existe de veggie-shops, idéelle ensuite, qui trouve dans chaque réseau social l'occasion de rendre ostensible sa différence éthique. Mais au-delà de ce processus quasi inexorable caractéristique de toute contre-culture, la spécificité du style veggie réside dans la tentation qui le tient de s'infiltrer comme gouvernance des corps individuels, comme outil de régulation des corps dont on considère qu'ils seront d'autant plus sains qu'ils seront mois animal, voir non-animal.

\section{INTERIORISATION DE LA BIOPOLITIQUE}

Il ne faudrait pas se rendre aveugle en effet à ce fait quaujourd'hui le pouvoir semble se dissoudre dans la question du style. Depuis la société de consommation propre à la culture de masse moderne qui reste encore l'étoffe de nos pratiques quotidienne (BAUDRILLARD, 1970), et depuis aussi cette société du spectacle qui médiatise et éloigne dans un même temps l'intensité des images et des sentiments (DEBORD, 1992), le pouvoir s'est trouvé médiatisé et en retour, qui veut conquérir le pouvoir doit nécessairement passer par les méandres du spectacle. Le pouvoir d'un style savère alors essentiel dans le processus de légitimation des minorités qui cherchent à se rendre toujours plus visibles, audibles et influentes. Comme le souligne Serge Moscovici (1991, p. 126), "le style de comportement est spécifiquement lié aux phénomènes d'influence”. C'est bien en faisant de soi l'étendard d'un comportement alternatif que le style veggie a pu étendre sa sphère d'influence.

En l'occurrence le pouvoir que convoite l'animalisme au travers du style veggie peut être compris en interrogeant l'évolution de la notion de biopolitique initialement conceptualisée par Michel Foucault à la fin des années 1970. Foucault a étudié les technologies de pouvoir et de souveraineté qui, à partir du XVIIIe siècle, ne concernent plus tellement les 
questions relatives à la mort (laisser vivre et faire mourir) mais bien davantage à la vie pour elle-même (faire vivre et laisser mourir). Une biopolitique qui concerne dorénavant, depuis la modernité, les corps des sujets individuels comme autant d'objets d'une espèce d' "anatomopolitique". (HELLER, 2005) Le pouvoir souverain emprunte alors les voies de nouveaux mécanismes disciplinaires et normalisateurs qui couvrent une surface toujours plus exhaustive de l'existence individuelle. Il est possible d'envisager quau-delà de ces mécanismes en tant que nouvelles formes de l'exercice du pouvoir, il y a une dynamique d'intériorisation des normes et des disciplines coercitives selon les modalités d'une autocontrainte faisant "glisser" le biopouvoir pourrait-on dire étatique vers une bioéthique politique individuelle. La gestion, la régulation et le contrôle de la vie des individus sont de moins en moins gouvernés par des appareils étatiques mais toujours davantage par la mise en place d'éthiques concurrentielles (néanmoins prosélytes) qui se proposent de donner sens à nos pratiques quotidiennes ordinaires, à nos conduites les plus triviales, celles qui consistent à se nourrir, se vêtir, se divertir, se soigner, etc. Le veganisme s'insinue ainsi, sous diverses enseignes disséminées au cœur de l'expérience urbaine, en tentant de configurer, reconfigurer les comportements relatifs à l'hexis corporelle.

Lon serait tenté de continuer la réflexion quant à la dimension biopolitique du style veggie en envisageant l'apport des théorisations d'Herbert Marcuse au sujet de la "désublimation répressive". Si la sublimation, selon l'héritage conceptuel freudien, correspond à la capacité de transcender la vie et de transformer les pulsions (Éros et Thanatos) en d'autres formes de productions culturelles, la désublimation chez Marcuse correspond au rejet du potentiel transformateur ou transcendant du réel. À la lecture d'Éros et civilisation, cette désublimation doit être comprise par sa qualité répressive dans le sens où précisément elle se déploie comme effet secondaire et pervers des contrôles sociaux et de la technologie qui, tout en généralisant la liberté, intensifie la domination. (MARCUSE, 1963) Il y a là continuité dans l'idée d'une contrainte (autocontrainte et auto-assujettissement) des individus au principe de 
réalité qui ne tolère plus le dépassement du réel de l'exploitation animale (et en premier lieu la mort animale qui par les images devient toujours plus obscène) et s'inscrit dans une éthique totalisante régulatrice des moindres aspects de la vie quotidienne. La désublimation répressive peut s'entendre alors comme une "administration totale de l'existence humaine [qui] tend à être vécue dans le bonheur (en fait le bonheur d'une vie mutilée!)". (LACHAUD, 2009, p. 143) Les auteurs de l'École de Francfort, non sans exprimer leurs querelles intestines, poussent une réflexion fine et complexe des processus d'aliénation dans le cadre des sociétés libérales. Théodore Adorno en particulier permet de saisir les limites de quelques volontés émancipatrices dans l'imposition d'une pratique, d'un exercice de vie, prenant impulsion sur l'idée d'un dépassement mais qui en réalité se laisse appréhender par la notion de désublimation. Dans ses "Notes sur la théorie et la pratique", Adorno discute d'une praxis "devenue son propre fétiche" et critique ainsi ce qu'il appelle des "activistes", ${ }^{1}$ fascinés par la tactique, entraînés dans une

spirale diabolique où se mélangent violence, autoritarisme [...] (Au lieu de se heurter à des arguments, on se heurte à des slogans stéréotypés délivrés manifestement par des chefs et leurs acolytes) et irrationalité (Par rapport au pouvoir réel, qu'il dérange à peine, l'activisme est irrationnel). (LACHAUD, 2009, p. 146)

Adorno - au moment des révoltes de mai 68 - doutait ainsi du potentiel réalisateur d'une contestation violente et radicale pour l'instauration d'un idéal utopique. Et, si l'on croise les perspectives théoriques et les intuitions des auteurs que nous avons cités ici, il semble que toute rébellion qui se dresse contre le système participe in fine à la relance de ce même système. C'est suivant ce processus que l'ascétisme animaliste des débuts s'est transformé en un style veggie devenu inoffensif mais qui joue le rôle d'étendard, de blason, de marque ou de griffe contre-culturelle dans les métropoles contemporaines.

1 Cité par Jean-Marc Lachaud (2009). 


\section{CONCLUSIONS}

Le mode de vie idéal et en un sens exemplariste de l'animalisme militant s'est doucement défiguré en un style qui est en même temps modalité consommatoire dorénavant distillée et par-là édulcorée, placardée comme tout autre produit publicitaire. C'est là où Adorno raisonne juste lorsqu'il parle des "slogans stéréotypés" dont l'irrationalité n’enfreint en rien le développement toujours croissant et résurrectif du libéralisme. La tranquillité du hype veggie se déploie toutefois comme moteur d'une autorégulation (autocontrainte) puissante et qui manifeste à sa manière la façon dont la biopolitique (le "faire vivre" de Foucault) s'est petit à petit individualisée dans la praxis quotidienne et vécue comme choix éthique. Or, précisément, c'est par l'individualisation de la biopolitique comme outil de contrôle des corps que le style veggie est aussi la manifestation d'une désublimation répressive, impuissant dans son potentiel révolutionnaire mais qui intensifie le rejet généralisé des tentatives de sublimation du réel. Là réside sans doute l'enjeu des temps à venir, trouver les moyens de renouer avec le sublime seul, peut-être, capable de signifier ou de re-signifier notre agir quotidien.

\section{REFERENCES}

BAUDRILLARD, J. La société de consommation. Paris: Gallimard, 1970.

DEBORD, G. La société du spectacle. Paris: Gallimard, 1992.

FOUCAULT, M. La naissance de la biopolitique: cours au Collège de France (1978-1979). Paris: Le Seuil, 2004.

GOFFMAN, E. La Mise en scène de la vie quotidienne. Paris: Les Éditions de Minuit, 1973.

HEATH, J.; POTTER, A. La révolte consommée: le mythe de la contreculture. Paris: Éditions Naïves, 2005.

HEBDIGE, D. Sous-culture: le sens du style. Paris: Zones Éditions, 2008.

HELLER, T. De l'anatomopolitique à la psychopolitique. Études de Communication, Villeneuve d'Ascq, v. 28, p. 59-75, 2005. 
JOY, M. Introduction au carnisme: pourquoi aimer les chiens, manger les cochons et se vêtir de vaches. Paris: LÂge de L'homme, 2016.

LACHAUD, J. M. Du “Grand Refus” selon Herbert Marcuse. Art et Politique, Paris, n. 45, p. 137-148, 2009.

LYOTARD, J. F. La condition postmoderne. Paris: Les Éditions de Minuit, 1979.

MAFFESOLI, M. Temps des tribus. Paris: La Table Ronde, 2000.

MARCUSE, H. Éros et civilisation. Paris: Les Éditions de Minuit, 1963.

MAUSS, M. Sociologie et anthropologie. Paris: PUF, 1997.

MOSCOVICI, S. Psychologie des minorités actives. Paris: PUF, 1991.

TOFFLER, A. Le choc du futur. Paris: De Noël Éditions, 1971.

VIDAL, B. "Post catastropham omne animal triste est": pop-cultures du désastre et consommation ordinaire de l'extraordinaire événementiel. Sociétés, Paris, n. 126, p. 71-80, 2014. 



\section{Comidas e cidades múltiplas apropriações do consumo alimentar na mídia}

DANIELA MENEZES NEIVA BARCELLOS, IGOR SACRAMENTO,

MARIA CLÁUDIA DA VEIGA SOARES CARVALHO E RICARDO FERREIRA FREITAS

\section{INTRODUÇÃO}

Cotidianamente, somos convidados a experiências multissensoriais e de infinitas ressignificações na cidade, lugar de produção de subjetividades e afetividades que se inscrevem nos corpos dos indivíduos. Sons, silêncios, cheiros, memórias, cores, encontros e sabores. Múltiplos sentidos e significados transitam no palco das urbes em que somos protagonistas e espectadores, simultaneamente.

Nesse entrecruzar de sensações e emoções, observamos a efervescência de narrativas sobre o comer, temática que se consolida e invade nosso dia a dia, sobrecarregado do que nos é permitido acessar para sobreviver 
entre luzes e sombras. As pautas sobre alimentação repercutem sensibilidades, demandam representações existentes no imaginário coletivo e tomam o espaço urbano e as mídias ininterruptamente. Conforme podemos observar neste trecho da matéria com o título "Comida não é remédio, não!”, publicada na revista Vida Simples, Edição Especial Comer Bem: "Dos programas de televisão aos chefs alçados a celebridades, dos restaurantes caríssimos ganhando páginas em grandes jornais aos festivais de comida [...] vivemos o que chamou de 'Era da Comida'”. (VIDA SIMPLES, 2017, p. 24)

Elementos que condicionem o homem à existência humana são percebidos e fazemos uso deste aparato condicionante para nos nutrir neste espaço de trocas. Entre tendências que se multiplicam por todos os lados, nesse cenário, é preciso considerar o fenômeno da transmidialidade presente na cultura contemporânea, em que tanto mídias quanto as narrativas interagem e entrelaçam seus conteúdos. (JENKINS, 2006)

Desse modo, a valorização da alimentação, especialmente sob a perspectiva do saudável em suas múltiplas nuances, sofre massiva influência da mídia que se especializa abrindo caminhos para diversas leituras. O entrelaçamento entre a comunicação, a nutrição e as práticas de consumo realça a presença transversal da subjetividade nas questões sobre o saudável, sobretudo na cidade.

Partindo dessas ideias, construímos uma questão de estudo: no discurso das mídias, percebemos com certa frequência a incorporação de disposições que envolvem a temática da alimentação saudável no cenário plural da metrópole. Quais as representações de comida, de saúde e da cidade, nesse complexo entrecruzar de elementos simbólicos midiáticos, estão integradas na formulação de uma noção operatória "consumo de alimentação saudável"?

Sendo o objetivo deste artigo mapear uma bricolagem nas práticas de consumo alimentar do saudável voltada para um estilo urbano de ser e levando em conta a polissemia que compreende a temática do "saudável" em nosso cotidiano, para além da ausência de doenças, a estratégia metodológica foi selecionar a edição de uma revista representativa, 
Vida Simples - Edição Especial Comer Bem, e analisar especificamente as representações da comida, da saúde e da cidade nas narrativas de reportagens sobre o comer em suas relações nesse cenário, a fim de avaliar a influência dos meios de comunicação no cotidiano dos citadinos.

Consideramos, neste estudo interdisciplinar da Nutrição e das Ciências Sociais, que comida, saúde e cidade assumem sentidos e significados culturais a partir das trocas simbólicas concebidas nos contextos das relações sociais.

\section{IMAGINÁRIOS NAS MÍDIAS E CONSUMO}

Representações, símbolos, distinções, saberes, visões de mundo, estilos de vida e, sobretudo, tendências circulam sem fronteiras e configuram-se como a chave de remodelação da sociedade na cidade que, como diz Freitas (1996, p. 3), é um local de "explosões de códigos, estimulando novas fontes de significações [...] A cidade não se pertence mais. Ela pertence ao mundo". É justamente aí que se sobressaem os meios de comunicação, como importantes agentes na mediação da produção, interpretação e veiculação de imagens e representações.

Observamos que as mídias reproduzem determinadas concepções do mundo social que fazem parte do enredado imaginário social que alimenta e constitui narrativas e imagens na metrópole. Nesse contexto, é possível pensar sobre o arsenal de comunicação circulante entre os grupos com base na apropriação de todo o aparato simbólico herdado, atualizado, transmitido e incorporado ao cotidiano dos indivíduos.

A sociedade contemporânea impõe e se submete a um ritmo frenético e incessante de mensagens que, na sua maioria, tenta nos vender algo e fomenta os consumos imaterial e material, sendo essa a lógica do bombardeio comunicacional diário. Segundo o filósofo André Gorz (2005), a questão do consumo imaterial está pautada no conhecimento impresso no imaginário e considerada uma riqueza. Para o autor,

do mesmo modo que a cultura, a sabedoria, os saberes tácitos, as capacidades artísticas, relacionais, cooperativas, etc., o conhecimento é riqueza 
e fonte de riqueza sem ser, nem ter, um valor comercial, monetário. Ele é - como as outras capacidades humanas - mais do que apenas uma força produtiva, sem ser necessariamente um meio de produção. O conhecimento faz parte do mesmo modo que as outras que também é mais do que apenas uma força produtiva -, dessas riquezas 'externas' ou dessas 'externalidades' que são indispensáveis ao sistema de produção de mercadorias. (GORZ, 2005, p. 56)

De acordo com Gorz (2005), as riquezas chamadas primárias, como a solidariedade e os saberes cotidianos, desvelam a economia chamada de invisível que movimenta as relações e representações que abastecem a economia produtora de bens e serviços. "Dela resulta a capacidade de sentir, de amar, de se unir e de viver em paz com o próprio corpo, com a natureza e com o próximo”. (GORZ, 2005, p. 57)

Nesse sentido, retomar inicialmente os conceitos de representações sociais e imaginário é fundamental, já que são a própria estrutura social que organiza as experiências da sociedade. São chaves para se pensar além das fronteiras da razão e adentrar nos processos de produção de subjetividades do coletivo, do social, que constituem as visões de mundo dos grupos.

Émile Durkheim (2003), sociólogo e antropólogo, explicou um conceito importante para os estudos das Ciências Sociais e Humanas: o das representações coletivas, a partir do estudo pioneiro na teoria das representações sobre as religiões primitivas da Austrália. O conhecimento apreendido e transmitido em sua obra entende que a sociedade prevalece sobre o indivíduo. Dessa maneira, ela o constrói.

Agora, atualizadas nas representações sociais, do ponto de vista da psicologia social por Serge Moscovici (2009), não há como fazer, separadamente, uma análise do social e do individual, pois ambos estão em interação. "Pessoas e grupos criam representações no decurso da comunicação e da cooperação”. (MOSCOVICI, 2009, p. 41)

A historiadora Sandra Jatahy Pesavento e o sociólogo Michel Maffesoli foram alguns dos autores que se debruçaram sobre os estudos das representações e imaginário. Segundo Pesavento (2003, p. 43), “entende-se por imaginário um sistema de ideias e imagens de representação coletiva 
que os homens, em todas as épocas, construíram para si, dando sentido ao mundo". Sob o ponto de vista de Maffesoli (2001), a coesão inspirada pelas representações e o imaginário constitui-se no cimento social.

O imaginário é o estado de espírito de um grupo, de um país, de um Estado-nação, de uma comunidade, etc. O imaginário estabelece vínculo. É cimento social. Logo, se o imaginário liga, une numa mesma atmosfera, não pode ser individual. (MAFFESOLI, 2001, p. 76)

É nesse lugar na vida contemporânea, especialmente na cidade, em que os veículos de comunicação desempenham um papel social poderoso como meios de coesão por afinidade entre os grupos, que a profusão dos apelos midiáticos, calcados em representações, estrutura e organiza realidade e imaginário, objetividade e subjetividade a cada escolha, a cada passo dado nas práticas do cotidiano.

Frases, textos, depoimentos, imagens, expressões e estilos de vida transitam no emaranhado do imaginário em que as representações, sejam ideias, concepções, valores, tradições ou visões de mundo, são construídas, reconstruídas e disseminadas como estímulos a uma jornada sedutora e ininterrupta de consumo.

Segundo o sociólogo Mike Featherstone (1995, p. 119), "estilo de vida" na cultura de consumo "conota individualidade, autoexpressão e uma consciência de si estilizada". Cada pessoa na cidade é afetada pelo consumo de ideias, bens e serviços que denotam um modo de ser e estar no mundo, a partir de códigos de distinção e das relações sociais que mantém e estabelece. Esbarramos, neste momento, no conceito que o sociólogo Pierre Bourdieu (2013) chama de distinção social, um modelo de compreensão da realidade que nos permite ver o jogo social do qual participamos e perceber o funcionamento da sociedade, de modo a viabilizar a possibilidade de ação dentro dela a partir da apreensão de códigos, valores, regras e, sobretudo, da lógica desse jogo. Para o sociólogo,

o que está em jogo é precisamente a 'personalidade', ou seja, a qualidade da pessoa, que se afirma na capacidade de apropriar-se de um objeto de qualidade. Os objetos dotados do mais elevado poder distintivo são aque- 
les que dão melhor testemunho da qualidade da apropriação, portanto, da qualidade do proprietário, porque sua apropriação exige tempo ou capacidades que, suponho um longo investimento de tempo, como a cultura pictórica ou musical, não podem ser adquiridas à pressa ou por procuração; portanto, aparecem como os testemunhos mais seguros da qualidade intrínseca da pessoa. Por isso, explica-se o espaço reservado pela procura da distinção a todas as práticas. (BOURDIEU, 2013, p. 263)

Com isso, é fundamental saber como identificar e agir nesse jogo do consumo que se impõe ao cotidiano, sobrecarregado de discursos e ofertas, e que leva as pessoas a ocuparem espaços privilegiados entre seus pares, particularmente, neste estudo, pela forma como se alimentam e como cuidam de suas vidas em busca de juventude, saúde e beleza em seus amplos aspectos.

\section{BRICOLAGEM NAS PRÁTICAS DE CONSUMO ALIMENTAR DO SAUDÁVEL}

Neste entrecruzar de elementos simbólicos que envolvem as temáticas da alimentação, mídia, consumo, corpo e cidade, o objetivo deste artigo foi delimitar disposições para uma alimentação saudável no cenário plural da cidade. Procuramos, assim, mapear tendências, saberes, entre outros elementos significativos das narrativas comunicacionais que fluem até nós e que trazem aspectos interessantes para o nosso debate. Muitas vezes, nas entrelinhas, são evidentes certas enunciações que passariam despercebidas e que estabelecem uma bricolagem nas práticas de consumo alimentar do saudável voltada para um estilo urbano: “'Desintoxique-se já!', 'Os elementos da comida limpa”. (VIDA SIMPLES, 2017, p. 24) Manifestações linguísticas e comunicativas que propõem uma reflexão mais crítica sobre sentidos e significados de conteúdos atribuídos à alimentação nos exigem o debate.

Trabalhamos com a ideia de bricolagem alimentar, conforme Carvalho (2013, p. 17-18): "Bricolagem alimentar foi uma estratégia que atravessou as práticas de alimentação [...] como um modo de 'arrumar' o universo simbólico, uma estratégia de organização dos 
significados dos alimentos na vida das pessoas". O presente trabalho, de natureza qualitativa, tem como unidade de análise duas matérias jornalísticas que tomam a bricolagem alimentar como parte constitutiva de muitos discursos e, de certa forma, reverberam por todos os textos selecionados, de modo direto ou velado, ao consumo do saudável, hoje considerado um rótulo fortemente capitalizado. Seja para reproduzi-lo, reforçá-lo ou questioná-lo, "saudável” está presente fortemente e delimita seus contornos conforme o contexto em que está inserido. Pode incorporar diferentes sentidos e significados e a ideia é colocar as narrativas em estudo numa esteira que nos permita refletir sobre a construção desses conteúdos, suas articulações, o que representam e seus simbolismos dentro de um veículo de comunicação. Igor Sacramento (2015, p. 112) reforça esse aspecto do saudável no indivíduo contemporâneo:

Nesse sentido, estar saudável não é mais somente o oposto de estar doente, mas implica as ideias de qualidade de vida, bem-estar, autorrealização e autoestima. $\mathrm{O}$ redimensionamento dessas fronteiras trouxe impactos de várias ordens, do ponto de vista da sua temporalidade e da ação do sujeito humano.

Em termos mais gerais, segundo Carvalho (2013, p. 70), entendemos que a diversidade cultural da sociedade contemporânea participa do processo de construção e reconstrução da bricolagem alimentar, carregada de significados simbólicos e nutricionais, que às vezes parecem estar em coesão e, em outros momentos, em conflito. Bricolagem, para o antropólogo Massimo Canevacci (2001, p. 244), seria um

modelo atual de difusão das ideologias [que] poderia ser definido como um tipo ventríloquo, no sentido de que a ideia nasce, é emitida, reproduzida e comunicada diretamente pelas coisas, pelo produto-mercadoria, pelo gadget.

Para compreendermos as associações que se articulam no imaginário que se constrói no universo da alimentação, é fundamental atentar que a comida e o comer são fenômenos sociais e culturais. Sendo assim, a comida não desempenha somente o papel de se constituir como 
uma fonte de nutrientes para a sobrevivência, mas também alimenta o indivíduo por meio de gratificações emocionais e torna-se um meio de expressar os valores culturais e as relações sociais de um grupo. Ou seja, altamente capitalizada para combinar os mais díspares arranjos simbólicos e de consumo. Para Carvalho (2013, p. 71),

o sentir e o imaginar se articulam nas práticas alimentares quando refletem ou se constroem no espaço social como ideias de todos, sonhos coletivos. As pessoas degustam e consomem os alimentos juntamente e a um consenso simbólico de um imaginário coletivo.

Por isso, a mídia não veicula somente a ideia da alimentação saudável com o conhecimento científico da Nutrição ou supervalorizando características dos produtos, mas também destaca reflexões sobre a mitificação dos alimentos, realça a sensação do prazer e da satisfação pelo gosto e o estabelecimento e a manutenção das inclusões ou exclusões sociais promovidas pela alimentação.

Como mencionado anteriormente, o presente estudo caracteriza-se como uma pesquisa qualitativa. Selecionamos a revista Vida Simples, especificamente uma Edição Especial veiculada em 2017, Comer Bem, com uma seleção de reportagens sobre alimentação. Entre as matérias, elencamos duas que estão alinhadas às tendências que emergem no espaço metropolitano contemporâneo e trazem conceitos e reflexões atuais e, portanto, estão presentes em nosso cotidiano de diversas formas: “Comida não é remédio, não!”, na seção Prazer em comer, e "Quando comecei minha horta urbana", na Plantar e colher.

Vida Simples é uma revista lançada pela editora Abril e que, em 2014, foi incorporada à editora Caras e, em 2018, foi comprada por Luciana Pianaro e Eugenio Mussak. Publicada mensalmente, foi escolhida no mundo editorial para representar um veículo de comunicação na presente pesquisa. Segundo o site da revista, ${ }^{1}$ que traz dados de

1 A revista Vida Simples não consta atualmente entre os veículos auditados pelo Instituto Verificador de Circulação (IVC). Os dados referentes à circulação da revista Vida Simples foram obtidos no site da publicação à época do estudo. 
março de 2016 do Instituto Verificador de Circulação (IVC), responsável pela auditoria de circulação dos principais jornais e revistas do país, a cobertura da revista atinge cerca de 61 mil leitores, sendo que a maioria, 61\%, é da região Sudeste do Brasil, lugar formador de opinião em relação ao objeto deste estudo e que confere capital e valor urbano para além das fronteiras, independente do espaço geográfico em que esteja. É uma revista representativa para esse tipo de veículo no universo da comunicação. Ocupa o seu lugar, entre os jornais e os livros, e compartilha discursos que fluem no universo cosmopolita preenchidos de representações e valores simbólicos, "entrando em contato com personagens do cotidiano, partilhando seus problemas, passatempos e prazeres". (OLIVEIRA; VELLOSO; LINS, 2010, p. 13)

Conforme nos explicam Oliveira, Velloso e Lins (2010, p. 12),

situando-se entre os jornais e os livros, as revistas desempenharam o papel de mediadoras de saberes, de práticas sociais e de linguagens. Nem tão imediata quanto a matéria trazida pelos jornais, nem tão reflexiva quanto a sugerida pelos livros, elas conseguem trilhar esse caminho singular, combinando notícias, reflexão e entretenimento, além de serem, é claro, instrumento imprescindível de atualização. Por todos esses atributos, elas vão angariar enorme popularidade.

As matérias cuidadosamente construídas a partir dos quatro pilares que estruturam sua marca, autodesenvolvimento, escolhas, relações e estilo de vida, segundo a descrição no site da revista Vida Simples, encontram-se alinhadas ao objetivo editorial da publicação.

O objetivo de VIDA SIMPLES é propor ao leitor mudanças que tragam mais significado e satisfação para cada dia, transformando sua relação consigo mesmo e com o mundo. Aborda temas como trabalho, família, meio ambiente e autoconhecimento através de reportagens profundas e reflexivas. Apresenta, também, ideias de pessoas que estão melhorando a realidade ao redor graças ao olhar sensível sobre a vida.

O processo metodológico escolhido para este estudo é a análise de conteúdo das duas matérias selecionadas, com base nos estudos de Laurence Bardin (2010). Segundo a autora, a análise de conteúdo 
consiste em "um conjunto de técnicas de análise das comunicações que utiliza procedimentos sistemáticos e objetivos de descrição do conteúdo das mensagens". (BARDIN, 2010, p. 40)

Na revista Vida Simples, essencialmente urbana, a cidade é parte integrante dos textos. Nesse panorama, levamos em conta os conteúdos relacionados à alimentação saudável e ao seu consequente consumo, seja imaterial ou material. A possibilidade da junção dos dados quantitativos e qualitativos coletados no recorte textual proposto promove uma análise mais profunda das narrativas em questão.

A análise de conteúdo é apenas um método de análise de texto desenvolvido dentro das ciências sociais empíricas. Embora a maior parte das análises clássicas de conteúdo culminem em descrições numéricas de algumas características do corpus do texto, considerável atenção está sendo dada aos 'tipos', 'qualidades', e 'distinções' no texto, antes que qualquer quantificação seja feita. Deste modo, a análise de texto faz uma ponte entre um formalismo estatístico e a análise qualitativa dos materiais. No divisor quantidade/qualidade das ciências sociais, a análise de conteúdo é uma técnica híbrida que pode mediar esta improdutiva discussão sobre virtudes e métodos. (BAUER; GASKELL, 2010, p. 190)

Neste ponto, consideramos todos os elementos pertinentes a este estudo como fundamentais à reflexão crítica dos conteúdos publicados, a fim de interpretar as nuances desse fenômeno comunicacional que é a temática da alimentação saudável na cidade. Para Canevacci (1993, p. 38), "recomeçar a observar os fenômenos, não mais com as tradicionais grades interpretativas, mas abandonando-se ao objeto da pesquisa e avançando hipóteses cautelosas que orientam a reflexão", é a chave para o sucesso da interpretação dos sentidos e significados inscritos nos discursos apurados na publicação.

Fizemos um recorte nas narrativas a fim de investigá-las a partir de categorias que estabelecemos para desvelar as construções dos textos nesse cenário de alimentação na cidade. Laurence Bardin (2010, p. 38-39) considera este método simples, denominado análise categorial, como um procedimento que permite desinvisibilizar os conteúdos, 
levando "em consideração a totalidade de um texto, passando-o pelo crivo da classificação e do recenseamento, segundo a frequência de presença (ou de ausência) de itens de sentido". Tendo como pano de fundo o cenário da cidade como palco das temáticas de alimentação e saúde, bem como a leitura atenta às múltiplas apropriações do consumo da alimentação saudável em seus amplos aspectos, as quatro categorias construídas para compreender os sentidos e significados das narrativas das matérias selecionadas são: tendências, saberes em saúde, mídia e corpo.

Quadro 1-síntese para a análise

\begin{tabular}{|l|l|l|}
\hline Aspecto analisado & Categorias & Amostragem \\
\hline $\begin{array}{l}\text { Tema central - Comidas } \\
\text { e cidades: múltiplas }\end{array}$ & 1. Tendências & Duas matérias da Edição \\
apropriações do consumo & 2. Saberes em saúde & Especial da revista Vida \\
alimentar na mídia na & 4. Corpo & Simples - Comer bem, 2017: \\
revista Vida Simples & & "Comida não é remédio, não!" \\
& & e "Quando comecei minha \\
horta urbana".
\end{tabular}

Estabelecemos, portanto, essas quatro categorias de análise de textos de uma revista representativa do cotidiano urbano contemporâneo. Procuramos desvelar o segmento que ocupou papel de destaque na produção e reflexo de significações e representações, embora haja entre eles uma inter-relação. A seguir, reflexões sobre a análise de conteúdo do presente artigo.

\section{AS REPRESENTAÇÕES DA COMIDA, SAÚDE E CIDADE: REFLEXÕES SOBRE AS MATÉRIAS}

Nossa análise buscou interpretar as reportagens como materiais simbólicos que compõem a cultura contemporânea. Sendo assim, analisamos especificamente as representações da comida, da saúde e da cidade, bem como as suas articulações na revista Vida Simples, a partir das categorias de análise que construímos. 
Consideramos comida, saúde e cidade como os elementos constitutivos de todo o cenário que embasa este estudo e, portanto, as representações associadas a essas temáticas se refletem por todas as narrativas do estudo demarcadas entre as quatro categorias.

A primeira delas, "tendências", compreendeu as representações associadas aos novos significados conferidos à alimentação saudável nesse cenário, como produtores de tendências em evidência no contexto urbano, com temporalidade oscilante, de forma a orientar modos de comportamento do indivíduo em grupos amparados por determinados estilos de vida, além de capacitá-lo com códigos que o insiram socialmente numa rede de consumo de bens imateriais e materiais que legitimará suas relações.

"Saberes em saúde" foi a segunda categoria construída para abarcar aspectos relacionados à compreensão, incorporação ou expressão de um saber que tendem a representar o conhecimento científico ou por reunirem discursos de influência no meio social formulados por especialistas ou profissionais da área em questão, independentemente de estarem legitimados por estudos ou pesquisas científicas.

Chamada de "mídia", a terceira categoria elaborada está diretamente relacionada à ideia dos meios de comunicação como mediadores da produção, interpretação e disseminação de imagens e representações que transitam no imaginário social.

"Corpo" é a última categoria e abarcou os discursos que busquem produzir sentidos nos indivíduos através de um padrão estético que se impõe numa época e dos cuidados com a saúde por meio de um viver saudável.

A revista Vida Simples, em suas duas matérias referentes à Edição Especial Comer Bem, de 2017, com o olhar voltado para alimentação, publicou argumentos a partir das questões do saudável, envolvendo as temáticas das quatro categorias selecionadas para este estudo. A categoria "tendências" totalizou 31 narrativas e apresentou a maior frequência. "Saberes" e "corpo" contaram com cinco inserções em cada categoria. "Mídia" reuniu um único discurso. Portanto, entre as narrativas analisadas, "tendências" afloraram e assumem seu papel central nas duas matérias analisadas. 
Segundo Barcellos (2016, p. 134),

impressões, valores, visões de mundo, tradições, representações de todas as ordens referentes ao universo da alimentação saudável associada à qualidade de vida, transformam as realidades. Colocam-se através das questões referentes à alimentação a cada instante sob uma lógica que estimula os diferentes interesses em um determinado momento, seja para atender o lado da produção-consumo-comunicação ou o lado do público receptor. Refletem-se nos imaginários nas mídias e comandam toda uma rede de produção e de consumo.

A pauta da alimentação saudável trafega no imaginário social e promove no universo midiático, a partir da análise deste estudo, experiências atuais e inspiradoras para viver o jeito urbano de ser alinhadas aos novos sentidos produzidos na metrópole contemporânea.

\section{"Comida não é remédio, não!"}

Na primeira matéria deste estudo, durante a leitura do texto composto por 33 narrativas, os conteúdos concentraram-se entre as quatro categorias, sendo "tendências" a que se sobressaiu, com 23 inserções. Começaremos por ela. Estabelecemos distintas temáticas, entre elas a bricolagem alimentar, que aparece como uma tendência mundial, com os seguintes componentes: manifestações linguísticas e comunicativas em geral e reflexão mais crítica sobre sentidos e significados. A narrativa que constituiu essa temática fez parte do grupo de atitudes rejeitadas, um posicionamento da revista contra o conteúdo em análise.

'Puro, cru, despido, nu, limpo e detox', 'Como não morrer...' Uma volta pelas seções de livros de gastronomia ou de nutrição das principais livrarias da Inglaterra fez com que o jornalista e escritor Steven Poole percebesse que havia alguma coisa errada ali. Especialista em linguagem - e no abuso que se faz dela - acho que aqueles títulos [...] pareciam mostrar uma relação não muito amistosa, para dizer o mínimo, com a alimentação. (VIDA SIMPLES, 2017, p. 24) 
Conforme afirma Carvalho (2013, p. 70), bricolagem alimentar é "um conceito que reinterpreta significados que ora se reproduzem com aparência caótica e criativa nas práticas de alimentação”.

Outra temática que também foi classificada como atitude rejeitada foi a da supervalorização do alimento, com 11 menções a partir dos componentes busca da saúde perfeita, alimento ideal, cultura do risco e distinção social.

Tornamo-nos obcecados pela comida [...] a ponto de queremos saber de onde ela procede, onde comprar, de que forma preparar, como comer. Se no princípio isso poderia indicar um bom sinal - afinal, maior consciência sobre o que colocamos no prato poderia ser uma forma de ressignificar nossa relação com a alimentação -, no final das contas acabou descambando para uma espécie de neurose. (VIDA SIMPLES, 2017, p. 24)

As especificidades dos conteúdos em análise denotam a posição da revista desde o tom do título da matéria, enfatizando o quanto a comida ultrapassa a fronteira do saudável sob o aspecto da ausência de doença. Seria uma nova tendência sobrepondo-se à da medicalização do alimento, já estabelecida e também mencionada na matéria, com duas narrativas classificadas como atitudes rejeitadas, e que detém, em seus componentes, referências aos nutrientes e aspectos funcionais da alimentação. "A comida substituiu as drogas no panteão do prazer. Tanto que tem trazido com ela um vocabulário cada vez mais farmacêutico". (VIDA SIMPLES, 2017, p. 24) Segundo Neves e colaboradores (2015, p. 26), a conduta predominante

ainda centrada no modelo biomédico, continua ignorando ou minimizando os papéis sociais do alimento, reduzindo-os a suas características funcionais. O profissional nutricionista, a partir do momento em que passa a conduzir sua atuação profissional em conformidade com as novas práticas profissionais, desempenha papel relevante no processo de medicalização da alimentação observado na contemporaneidade.

Nessa cultura do risco, a revista adota uma postura sustentada por questões socioculturais que iluminam os excessos acerca da supervalorização do alimento. 
Assim como transtornos como a anorexia ou a bulimia, a ortorexia é um problema alimentar, mas desta vez causado pelo exagero da ideia de comida saudável, uma busca incansável pelos benefícios nutricionais daquilo que se ingere. (VIDA SIMPLES, 2017, p. 24)

Como explicam Castiel, Guilam e Ferreira (2010, p. 9), "esse ambiente 'riscofóbico' pode configurar uma estratégia limitante e produtora de ansiedades e inseguranças ao propor formatos restritivos de condução do comportamento das pessoas". Um questionamento proposto no texto alinha-se a esse pensamento: "Quando foi que comer se tornou um ato marcado pela ansiedade sobre procedência, estilo de vida, saúde e status social?”. (VIDA SIMPLES, 2017, p. 24)

Esbarramos na temática "medo da comida", também constituída por três discursos rejeitados.

As pessoas estão desesperadas [...] se castigando com dietas impossíveis, com promessas desintoxicantes (que muitos artigos científicos refutam que existam) e se privando daquilo que gostam de comer por puro medo da comida. (VIDA SIMPLES, 2017, p. 28)

Foram encontrados os seguintes componentes das narrativas que comprovam os argumentos dessa categoria: novos sentidos e significados, conflitos com a comida e privações por excessos de cuidados com a saúde.

Em contraponto a essa ideia, encontramos, em outras narrativas, temáticas acerca do valor do alimento saudável combinado com outras questões que ampliam sua significação e são, portanto, narrativas valorizadas pela revista e em acordo com a seção em que a matéria está inscrita: Prazer em comer. Uma delas foi a temática "comida não é remédio", em harmonia com a ideia principal do texto.

Medicalizar a alimentação é distúrbio. Coma comida, não nutrientes. Coma variado e os nutrientes estão garantidos. Exclua ultraprocessados [...] A chamada medicalização da alimentação transforma a comida em inimigo e acaba com o prazer de comer. (VIDA SIMPLES, 2017, p. 26)

Os componentes que envolveram as três narrativas dessa temática foram valorização da comida para além dos nutrientes e dimensões culturais e sociais das práticas alimentares. 
A última temática que integrou a categoria "tendências" foi alimento como fator social, com abordagens valorizadas pela publicação. Os componentes que embasaram os argumentos das três narrativas dessa temática foram vínculo aos valores culturais e familiares e comensalidade.

A batalha a ser enfrentada na nossa relação com a alimentação não tem a ver com encontrar a dieta perfeita (e a combinação exata de nutrientes que ela pode oferecer), mas sim com o fato de colocarmos o prato em seu lugar de direito e reconstruir a essência do vínculo que estabelecemos com aquilo que levamos à boca. (VIDA SIMPLES, 2017, p. 28)

A categoria "Saberes em saúde”, atitudes valorizadas, temática saberes técnicos, somou cinco inserções. Os componentes descritos foram saberes legitimados por uma classe ou área, valor cognitivo, nutrição e práticas alimentares. Nesta narrativa, uma breve explicação sobre o Guia Alimentar para a População Brasileira.

Trata-se de um dos documentos mais completos sobre nutrição pensado para a população brasileira - e elogiado inclusive por profissionais da área em outros países. Lançado pelo Ministério da Saúde, o guia é um compêndio que busca falar da alimentação de uma forma holística: em vez de trabalhar com grupos alimentares e porções recomendadas, por exemplo, indica que a alimentação tenha como base alimentos frescos (frutas, carnes, legumes) e minimamente processados (como arroz, feijão e frutas secas). (VIDA SIMPLES, 2017, p. 26)

A categoria "mídia" apresentou a temática transmidialização, ancorada no conceito de narrativa transmídia (JENKINS, 2006) em que os conteúdos dialogam e entrelaçam-se entre múltiplas plataformas midiáticas. Uma única narrativa foi valorizada, tendo como componentes novos sentidos e comunicação entre mídias. “[...] dos programas de televisão aos chefs alçados a celebridades, dos restaurantes caríssimos ganhando páginas em grandes jornais aos festivais de comida [...] vivemos o que chamou de 'Era da Comida”'. (VIDA SIMPLES, 2017, p. 24)

Para finalizar a análise desta matéria, a categoria "corpo" apresentou quatro inserções, consideradas rejeitadas pela revista. 
Com a sociedade do espetáculo, a imagem ganhou ainda mais importância, e o corpo se tornou um capital valioso (bastam alguns segundos navegando pelo Instagram para comprovar!). Todo alimento que pudesse colocar esses padrões em risco - ou arranhar a nossa ideia de saúde perfeita - era visto como vilão. (VIDA SIMPLES, 2017, p. 26)

Sob a temática "padrão estético", comportou os componentes sociedade do espetáculo, supervalorização da imagem e ideia de saúde perfeita. É nesse cenário da metrópole que nos aproximamos do conceito de espetáculo do escritor Guy Debord (2003, p. 16):

O conceito de espetáculo unifica e explica uma grande diversidade de fenômenos aparentes. As suas diversidades e contrastes são as aparências organizadas socialmente, que devem, elas próprias, serem reconhecidas na sua verdade geral. Considerado segundo seus próprios termos, o espetáculo é a afirmação da aparência e a afirmação de toda vida humana, socialmente falando, como simples aparência.

O corpo torna-se reflexo do cotidiano da cidade que se apresenta como um espetáculo e, nesse jogo de aparências e consumo, o padrão estético do corpo magro com musculatura definida surge, incorpora afetos e reconstrói representações que circulam na cena da metrópole.

\section{"Quando comecei minha horta urbana"}

A segunda matéria que deu sequência ao estudo, inscrita na seção Plantar e colher da revista, apresentou dez narrativas com conteúdos voltados para as categorias "tendências" e "corpo". Nove delas fizeram referência à categoria "tendências" e foram classificadas como atitudes valorizadas. $\mathrm{O}$ texto compõe aspectos que se referem à temática bricolagem da horta e seus componentes foram agricultura urbana, natureza e o homem, afetos, usos da cidade, iniciativas mundiais e espaços de socialização. "Eu sabia que, do ponto de vista da sustentabilidade, uma horta urbana era 'bastante legal', mas ainda não tinha entendido o poder de plantar em casa”. (VIDA SIMPLES, 2017, p. 31) 
A ideia da horta está presente no imaginário com suas representações ligadas ao cultivo de legumes, hortaliças, temperos, ervas, geralmente nas áreas rurais, o que traz a ideia do antigo e simples, do alimento cultivado no campo, de modo tradicional, artesanal, caseiro. Sensibilidades hoje, poderosamente, valorizadas e reconstruídas a todo momento e que se inscrevem, de múltiplas formas, no cotidiano urbano. "Me sentia o Marco Polo da agricultura sustentável, incumbido de levar à cidade um pouco do cheiro do Rio Pardo que ficou no meu tênis". (VIDA SIMPLES, 2017, p. 32) Segundo Carvalho (2013, p. 82), "na prática, os significados são reinterpretados na bricolagem, e não faz sentido buscar a origem, mas, sim, uma relação no universo de significação". E acrescenta,

O simbolismo de tradicional, regional, caseiro e artesanal se reinterpreta de nodo dinâmico nas trocas simbólicas. É na realidade de um contexto específico que as ideias de tradicional se fundem, ou não, com as de moderno, alcançando distinção social. (CARVALHO, 2013, p. 82)

Estamos estreitamente enredados ao conceito que Bourdieu (2013) chama de distinção social e, a partir de nossa perspectiva pessoal, perceber, no jogo social do qual fazemos parte, o que é valorizado ou não em certos espaços. O lugar social do indivíduo é concedido pelo modo como come, pelos alimentos que escolhe, pelas tendências que consome e pelas relações sociais que estabelece, por exemplo.

A antropóloga Mary Douglas e o economista Baron Isherwood trouxeram reflexões importantes a partir de um estudo pioneiro na área da Antropologia Econômica. Para eles, as relações sociais se estabelecem e se mantêm também através dos bens que os indivíduos consomem.

Em vez de supor que os bens sejam em primeiro lugar necessários à subsistência e à exibição competitiva, suponhamos que sejam necessários para dar visibilidade e estabilidade às categorias da cultura [...] ao mesmo tempo, é evidente que os bens têm outro uso importante: também estabelecem e mantêm relações sociais. (DOUGLAS; ISHERWOOD, 2013, p. 103)

As relações sociais se articulam nas práticas de alimentação, conforme a construção das narrativas da revista, a partir de componentes 
que unem o sentir, o imaginar e o reproduzir, acompanhados de um sentido valorizado de criação e compartilhamento que tomam os espaços sociais alinhados às inciativas mundiais.

Vi iniciativas como os Seeds Savers (salvadores de sementes), nos Estados Unidos, que criam bancos de sementes para salvar a biodiversidade. Vi agricultores urbanos na Espanha plantando nos espaços que ainda ousavam ser cinza. (VIDA SIMPLES, 2017, p. 32)

Para finalizar a análise levantada até esta matéria, a categoria "corpo" aparece com uma narrativa.

Agora estou mais atento à sazonalidade dos alimentos. Faz diferença saber que em tal época a cenoura cresceu menos, mas a batata está mais bonita. A gente vê que o meio está oferecendo aquele alimento prioritariamente. E que nosso corpo, harmonizado com isso, vai trabalhar melhor. (VIDA SIMPLES, 2017, p. 32)

A temática "cuidados com a saúde" associou os componentes de sazonalidade dos alimentos, impactos dos alimentos no corpo e viver saudável.

Percebemos, assim, que, nessa segunda matéria em análise, houve a predominância da categoria "tendências" na classificação das narrativas. Os critérios definidos para estabelecê-la assumiram as muitas significações do que seria uma horta. "Basta um manjericão, e já é horta. Na minha janela”. (VIDA SIMPLES, 2017, p. 32) Uma nova forma de ordenação global trabalha com as representações e se inscreve na cidade que encontra na mídia a força de potencializar suas tendências.

\section{PARA AONDE APONTAM OS NOVOS FLUXOS DE CONSUMO DE ALIMENTAÇÃO SAUDÁVEL NAS CIDADES?}

Neste estudo, buscamos refletir sobre as múltiplas apropriações do consumo alimentar do saudável na mídia, no cenário da cidade, recorrendo, para isso, a um olhar transdisciplinar entre sentidos e significados da subjetividade nos diálogos entres as áreas das Humanidades e das Ciências da Saúde. Consideramos, diante dos resultados apresentados, 
como as representações são construídas e reconstruídas em contextos específicos - da revista, das cidades, da saúde - assumindo que a cidade ora é produto, ora é produtora de subjetividades, afetividades e de narrativas, sobretudo neste estudo, referentes ao universo da alimentação, muito marcadas por tendências urbanas.

Pretendemos responder a uma questão de pesquisa construída a partir das ideias que se entrelaçaram neste estudo: quais as representações de comida, de saúde e da cidade, apropriadas de modo múltiplo neste complexo entrecruzar de elementos simbólicos midiáticos, estão envolvidas na construção da noção operatória de "consumo de alimentação saudável"?

As análises de duas matérias de uma revista representativa nos permitiram observar que os apelos às tendências, aos saberes em saúde, à mídia e ao corpo são constitutivos dos meios de comunicação. Encontram nos veículos a força para expandirem-se entre o público, consumidores de suas ideias, bens e serviços, que são também responsáveis por propagar valores, impressões, visões de mundo e estilos de vida que se inscrevem nos espaços sociais, reconstruindo-se a todo momento. A expressão midiática da diversidade de estímulos no cotidiano urbano é capaz de instituir conflitos entre escolhas sobre o "comer saudável” em seus amplos aspectos, o que requer nossa atenção.

Identificamos a predominância da categoria "tendências" nos dois textos analisados da revista Vida Simples, Edição Especial - Comer bem. Sendo assim, observamos uma combinação de elementos presentes na construção social, de modo oscilante e inovador, contribuindo com novos fluxos de consumo alimentar nas cidades.

Explorando um pouco mais, duas tendências sobressaíram-se pelo número de narrativas associadas a elas. Na primeira matéria, supervalorização do alimento obteve realce rejeitando e se contrapondo a esse processo acelerado de medicalização da alimentação, imperativo no espaço o urbano. Sob a lógica da promoção da saúde construída pela revista, devemos pressupor não apenas o valor nutricional dos alimentos e suas funcionalidades, mas incluir como de mesma importância os seus aspectos simbólicos que reconstroem a essência de nosso vínculo com a comida, sem 
excluir o contexto sociocultural em que se manifestam. No segundo texto, a temática "bricolagem da horta" destacou-se por valorizar a iniciativa de uma tendência mundial de trazer os ares da horta do campo para as urbes.

Dessa forma, especialmente por meio de tendências que se constituem e se propagam na cidade, a partir de representações, elementos simbólicos e atentos aos novos fluxos de consumo da alimentação saudável na cidade, nosso caminhar aponta para o fortalecimento dos estudos nesta linha e para a construção, com os braços da mídia, de uma noção operatória de consumo de alimentação saudável. Reconhecemos a importância de reconstruir representações, minimizar preconceitos, flexibilizar e atender os apelos biológicos e emocionais dos indivíduos, e não somente suas demandas imperativas produzidas por uma visão hegemônica de saúde, marcada fortemente como ausência de doença. $O$ fato de levantar esta reflexão permite trabalhar com o poder e o alcance das subjetividades e afetividades inerentes à vida em sua complexidade e inscritas no imaginário das urbes.

\section{REFERÊNCIAS}

BARCELLOS, D. M. N. Alimentação saudável e qualidade de vida na cidade: um estudo dos imaginários nas mídias. 2016. Tese. (Doutorado em Alimentação, Nutrição e Saúde) - Instituto de Nutrição, Universidade do Estado do Rio de Janeiro, Rio de Janeiro, 2016.

BARDIN, L. Análise de conteúdo. Lisboa: Edições 70, 2010.

BAUER, M. W.; GASKELL, G. (org.). Pesquisa qualitativa com texto, imagem e som: um manual prático. Petrópolis: Vozes, 2010.

BOURDIEU, P. A Distinção: crítica social do julgamento. Tradução de Daniela Kern e Guilherme J. F. Teixeira. Porto Alegre: Zouk, 2013.

CANEVACCI, M. Antropologia da comunicação visual. Rio de Janeiro: DP\&A, 2001.

CANEVACCI, M. A cidade polifônica: ensaio sobre a antropologia da comunicação urbana. São Paulo: Estúdio Nobel, 1993.

CARVALHO, M. C. V. S. Bricolagem alimentar nos estilos naturais. Rio de Janeiro: EdUERJ, 2013. 
CASTIEL, L. D.; GUILAM, M. C. R.; FERREIRA, M. S. Correndo o risco: uma introdução aos riscos em saúde. Rio de Janeiro: Editora Fiocruz, 2010.

DEBORD, G. Sociedade do espetáculo: comentários sobre a sociedade do espetáculo. Rio de Janeiro: Contraponto, 2003. Disponível em: http://www. ebookbrasil.org/eLibris/socespetaculo.html. Acesso em: 17 jul. 2015.

DOUGLAS, M.; ISHERWOOD, B. O mundo dos bens: para uma antropologia do consumo. Tradução de P. Dentzien. Rio de Janeiro: Editora UFRJ, 2013.

DURKHEIM, E. As formas elementares da vida religiosa: o sistema totêmico na Austrália. Tradução de Paulo Neves. São Paulo: Martins Fontes, 2003.

FEATHERSTONE, M. Cultura de consumo e pós-modernismo. Tradução de Julio Assis Simões. São Paulo: Studio Nobel, 1995.

FREITAS, R. F. Comunicação e espaços urbanos: relação essencial à contemporaneidade. Revista Logos, Rio de Janeiro, v. 3, n. 2, p. 3-4, 1996.

GORZ, A. O imaterial: conhecimento, valor e capital. Tradução de Celso Azzan Júnior. São Paulo: Annablume, 2005.

JENKINS, H. Convergence culture: where old and new media collide. Nova York: New York University Press: 2006.

MAFFESOLI, M. O imaginário é uma realidade. Revista FAMECOS: Mídia, Cultura e Tecnologia, Porto Alegre, v. 8, n. 15, p. 74-82, 2001.

MOSCOVICI, S. Representações sociais: investigações em psicologia social. Petrópolis: Vozes, 2009.

NEVES, A. S. et al. A nutrição na busca pela supernormalidade. In: PRADO, S. D. et al. (org.). Alimentação e consumo de tecnologias. Curitiba: CRV, 2015. p. 17-32.

OLIVEIRA, C.; VELLOSO, M. P.; LINS, V. O moderno em revistas: representações do Rio de Janeiro de 1890 a 1930. Rio de Janeiro: Garamond, 2010.

PESAVENTO, S. J. História \& história cultural. Belo Horizonte: Autêntica, 2003.

SACRAMENTO, I. Tornando a dor visível: o ethos terapêutico em narrativas testemunhais de celebridades sobre o câncer. Ciberlegenda, Rio de Janeiro, n. 32, p. 109-122, 2015. Disponível em: http://www.ciberlegenda. uff.br/index.php/revista/article/view/751/405. Acesso em: 13 jul. 2019.

VIDA SIMPLES. São Paulo: Caras, 2017. Edição especial. 


\section{Comida de rua corpo, emoções e etnocentrismo na cidade}

DENISE DA COSTA OLIVEIRA SIQUEIRA

\section{INTRODUÇÃO}

Fenômeno social e cultural, a produção jornalística contemporânea está inserida em um complexo de mediações que também contempla, entre diversos outros aspectos, regimes de afetos e de sentimentos, mas não menos o corpo e as corporeidades. A produção de matérias em torno de temas como culinária, gastronomia e comida, de um modo geral, seus efeitos sobre o corpo e as sensações que provocam, não escapa aos afetos.

Neste capítulo, promovemos uma discussão sobre a construção das emoções em materiais jornalísticos e a condição simbólica e midiática da comida de rua, reconhecendo-as como fenômenos localizados no bojo de processos sociais potencializados no espaço urbano. Para observar 
essas articulações, partimos de uma leitura do evento apelidado de Esfirraço, de apoio a um imigrante sírio-egípcio que sofreu um ataque de caráter xenofóbico em Copacabana, bairro carioca de características cosmopolitas e turísticas, no mês de julho de 2017.

Indignado com o incidente, por meio de uma rede social, um empresário brasileiro convidou pessoas para comer das esfirras de Mohamed em solidariedade ao estrangeiro. $\mathrm{O}$ evento em torno da comida de rua foi um sucesso midiático, com resposta de milhares de pessoas. Mas também gerou conflitos, como uma passeata de grupo contrário à presença de muçulmanos no Brasil, e desvelou a disputa por território para a venda de produtos nas calçadas de Copacabana. Buscaremos investigar a construção das emoções, os regimes de sentimentos e afetos em torno da figura de um estrangeiro e como o corpo e a comida foram fatores de aproximação e interação nesse processo.

Partimos da ideia de que, mais do que puramente alimento e nutrição para o corpo, a comida de rua produzida, comercializada e ingerida nos espaços urbanos é signo de cultura. É também elemento da interação social e, no caso estudado, marcador político e mídia. Em sua materialidade, as esfirras, quibes e outros pratos de origem árabe foram instrumentos do processo de interação social, de integração, contra o etnocentrismo e a xenofobia.

Para investigar essas articulações, estudamos matérias jornalísticas veiculadas em sites de publicações on-line, assim como no jornal carioca O Globo. Paralelamente, lemos comentários de leitores sobre o assunto publicados na página dedicada ao tema na rede social Facebook.

Fundamentamos teoricamente a investigação com uma abordagem da Antropologia das emoções (LE BRETON, 2009; MAUSS, 1969; REZENDE, 2002) para ler tanto o material jornalístico quanto os comentários dos usuários, compreendidos como expressão e parte de um fenômeno de ordenação da realidade social. Marcel Mauss (1974) e David Le Breton (2005) dão suporte à nossa leitura sobre corpo na cultura. Simmel (1973), Canclini (2007), Euler Siqueira e Denise Siqueira (2017) fornecem subsídios para um olhar sobre a cidade. 


\section{CORPO, CONSTRUÇÃO SOCIAL DA EMOÇÃO E JORNALISMO}

Assumindo o lugar de destaque em diversas culturas contemporâneas, a comunicação midiatizada divulga, amplia e explora afetos, emoções e sentimentos sob o formato de textos, imagens e sons. As redes sociais eletrônicas, mas não menos os espaços jornalísticos, mesclam informação, entretenimento e expressão de emoções.

Essa dimensão do sensível se expressa sobremaneira no corpo. Refletir sobre ela, sobre a construção social das emoções, sobre o que os gregos da Antiguidade chamaram de pathos e sobre o corpo possibilita questionar espaços, por vezes, relacionados predominantemente a racionalidades. Entre essas questões, interessa-nos, neste texto, refletir sobre relações sociais que se configuram partindo de uma articulação entre a mídia e os afetos e sobre o papel que o corpo ocupa em um contexto que envolve um estrangeiro, a comida relativa à sua cultura e um bairro emblemático como Copacabana.

Entendida como simbólica e, paralelamente, lugar de materialidades, a noção de comunicação se abre para abarcar o corpo e observá-lo como meio de expressão de valores, transgressões, sentimentos e emoções. Em uma perspectiva socioantropológica, essa comunicação também responde ao social, ao grupo e à cultura nos quais o sujeito e seu corpo estão inseridos.

Como escreveram Le Goff e Truong (2012, p. 10), “o corpo tem uma história”. Dito de outro modo, o corpo, que alguns pensaram natural, homogêneo e universal, durante a modernidade, é também o resultado de uma classificação social e simbólica. (LE BRETON, 2009; MAUSS, 1974) A própria noção de um corpo distinto da mente e inserido na natureza é uma construção cultural, ou, parafraseando o antropólogo Roy Wagner (2010), é uma invenção.

Nessa perspectiva, o conceito de técnicas corporais - chave nos estudos de corpo e sociedade, cunhado por Marcel Mauss - explica que atitudes tão naturalizadas como andar, correr e dar à luz são, na verdade, construções históricas e culturais que marcam o corpo. São 
cultura, que afeta o corpo, varia de acordo com o tempo e o lugar. Assim, tomando as técnicas corporais como aprendidas em sociedade (MAUSS, 1974), entendemos que os corpos que as praticam ocupam lugar cultural, deixam rastros que o analista social pode ler ao buscar compreender as histórias dos sujeitos e das sociedades em sua diversidade. O corpo é elemento fundamental na interação social.

O antropólogo francês David Le Breton, em seu livro As paixões ordinárias: antropologia das emoções, desenvolve um olhar sobre o corpo como espaço para a expressão das emoções. Para o autor, as emoções são emanações sociais ligadas a circunstâncias morais e à sensibilidade particular do indivíduo. Reforçando e atualizando o pensamento de sociólogos como Émile Durkheim (2007) e Marcel Mauss (1969), Le Breton (2009) entende que as emoções não são espontâneas, mas socialmente organizadas. Assim, "Reconhecidas em si e exibidas aos outros, elas mobilizam um vocabulário e discursos: elas provêm da comunicação social”. (LE BRETON, 2009, p. 120)

O corpo, assim como a emoção, é elemento constitutivo do processo midiático de construção de representações, de reforço de imaginários, de produção de sentidos. Nos noticiários, nas coberturas jornalísticas da TV aberta, nos informativos em plataformas digitais, no rádio e nos jornais - assim como nas artes da cena, no teatro e na dança -, surpresa, ansiedade, medo, alegria, decepção, nojo ocupam um lugar importante. Tal espaço ocupado pela expressão e representação das emoções se dá em grande parte por meio da exposição simbólica de corpos, suas técnicas corporais e de estratégias profissionais. Ou seja, na comunicação midiatizada, a expressão das emoções acontece, muitas vezes, como recurso estratégico, profissional. $\mathrm{O}$ apelo ao corpo e às emoções serve de recurso para divulgação de informações de um modo para além do verbal.

No campo jornalístico, nota-se que esse emprego de corpo e emoção em grande parte se dá em segundo plano, de forma a misturar-se com os discursos e a passar despercebido. Seu efeito é fundamental, mas deve ser velado, no sentido de que corpo e emoção são usados como elementos para reforçar alguma outra mensagem. Assim, pode-se dizer que 
Nos processos de comunicação, a emoção cumpre um papel fundamental porque reforça vínculos além de um modo estritamente racional/objetivo. E se a existência é afetiva, ela é, também, corporal. É o corpo, com seus gestos e palavras, que materializa a emoção. (SIQUEIRA, 2015, p. 10)

No campo das redes sociotecnológicas contemporâneas, há um outro vocabulário a dominar: o da expressão midiática. Aqui, sentir não é suficiente; é preciso expressar pelos meios de comunicação ou as redes sociais eletrônicas para parecer mais crível e gerar efervescência.

Émile Durkheim, na obra clássica As formas elementares da vida religiosa, destacou o conceito hoje importante para o entendimento do universo midiático contemporâneo: o de efervescência. As práticas religiosas em rituais contagiantes geram um desligar-se de si para participar de uma emoção coletiva. Essa abordagem encontra atualização em Maffesoli (2000) quando se refere a eventos que, na pós-modernidade agregam a capacidade de gerar efervescências, como shows musicais, eventos esportivos, campanhas caritativas midiatizadas.

Para Maffesoli (2012), a importância dos afetos reside justamente em constituir o "cimento" das sociedades pós-modernas na sua unicidade - aquilo que se compartilha além das divergências. Parafraseando outro autor, Miller (1997, p. 12), em seu estudo sobre o nojo, as emoções são humanas e humanizadoras e estão na base da estruturação do sujeito, das identidades.

A expressão das emoções surge em diferentes esferas da comunicação, mesmo as que assumem discursos mais objetivantes, como o jornalismo. Nele, a emoção parece ser, na realidade, uma condição necessária - não uma contradição, como se discute, por vezes, quando se estuda a linguagem jornalística.

Para o bem ou para o mal, o jornalismo pode recorrer aos efeitos da dramatização buscando tocar o receptor, provocar nele certo estado emocional favorável à recepção dos conteúdos e sentidos da notícia. Essa estratégia faz parte claramente das atividades publicitárias, de marketing e de relações públicas. No entanto, também surge em certos gêneros jornalísticos, como no jornalismo classificado como 
popular ou em veículos de características sensacionalistas, nos quais, por vezes, a criação das capas envolve, além de jornalistas, profissionais de outras formações.

Esse aspecto também fica claro no jornalismo esportivo e no cultural, assim como no político e no econômico - em tese, tido como menos afeito ao aspecto "entretenimento" da notícia, mas na prática tão sujeito a ele quanto os outros exemplos. A cobertura de política no Brasil em 2016 e 2017, cobertura do impeachment da presidente Dilma Rousseff, da Operação Lava-Jato e de outras da Polícia Federal são exemplos de temáticas do campo econômico-político brasileiro que mostram as tênues fronteiras entre jornalismo, informação, interesses e expressão de afetos e desafetos.

Ao promover a discussão sobre esse aspecto, uma questão se coloca: como retratar ou reportar o "real", os fatos, extraindo dele a emoção? A emoção faz parte do real, dos fatos. Excluir a emoção da perda, das tragédias, das dores do cotidiano duro seria negar uma parte do real, do fato social. Esse é um problema, talvez ontológico, da prática jornalística: porque ao assumir a emoção no texto, nas imagens, como acertar a medida sem recorrer ao contestável recurso de usar a emoção para "vender" notícia?

\section{CIDADE, ETNOCENTRISMO E COMIDA}

Corpos, emoções e as representações de ambos na comunicação midiatizada encontram espaço privilegiado para se difundir nas cidades. Metrópoles não se constituem somente como cenário no qual relações entre os sujeitos, interações acontecem. O espaço urbano é hoje experiência, processo construído no cotidiano. Assim, como escreveu Canclini (2007, p. 107), "Ante todo, debemos pensar en la ciudad a la vez como lugar para habitar y para ser imaginado".

As cidades constituem-se como produtoras de vivências, narrativas, subjetividades, emoções, corpos que se articulam. "Las ciudades se construyen con casa y parques, calles, autopistas y señales de tránsito. 
Pero las ciudades se configuran también con imágenes". (CANCLINI, 2007, p. 107) Nessa articulação, espaços simbólicos de poder, de público e de privado, exclusões e inclusões sociais, xenofobia e etnocentrismo também se constituem.

Lugar de comércio, de economias que se movem e atraem trabalhadores, "as grandes cidades, suas praças públicas e monumentos constituem espaços onde se exprimem e se confrontam múltiplas culturas contemporâneas". (SIQUEIRA, 2012, p. 51) A metrópole contemporânea é um carrefour, cruzamento de contradições, ideias e de corpos. E apesar de todos os ideais de descentralização que as redes informáticas permitem, a cidade ainda concentra os fatos e eventos que marcam a mídia, que constroem imaginários e estimulam o consumo. A cidade é o "centro do mundo" na medida em que estabelece com seus habitantes relações de socialidade, de interesse, de expectativa, de mobilidade social e econômica e de conflitos. (SIQUEIRA, 2012)

Desse modo, ao mesmo tempo em que abrigam a pluralidade, são local de intolerância e de disputas. Por isso, as cidades também abrigam reações ligadas ao estranhamento do outro, como a xenofobia e o etnocentrismo. Etnocentrismo é o que entendemos como uma relação hierarquizada e desigual entre dois ou mais grupos sociais. (ROCHA, 1984) "Consiste na centralidade que um grupo ou uma sociedade se atribui na comparação com outros”. (SIQUEIRA; SIQUEIRA, 2017, p. 104)

Como lugar privilegiado da produção material e simbólica, a cidade reflete a pluralidade da produção de sentidos. Essa pluralidade não "cabe" em sua totalidade nos meios de comunicação massiva. Os meios de comunicação tentam representá-la, mas na realidade selecionam alguns sentidos entre uma variedade quase infinita de significações presentes no espaço urbano. Dessa forma, a mídia oferece um ponto de vista, uma leitura - geralmente limitada ou "recortada"/editada para ser mais técnica - da cidade, de seus atores, de seus valores e suas referências.

Se os limites não são mais somente geográficos, eles nos fazem refletir que a cidade também pode estar nos corpos, na mídia, nos imaginários. Assim, a cidade é física à medida que compreende espaços e 
distâncias; ela é sociológica na medida em que compreende as relações sociais; é cultural porque construída e reconstruída por pessoas inseridas em culturas; e ainda, poderíamos dizer, é psicológica porque aproxima pessoas conhecidas e desconhecidas, o estranho, estrangeiro com todos os receios que ele provoca. A cidade é uma ideia.

Dessa maneira, a cidade é física, sociológica, cultural, psicológica, como um corpo. E ela afeta os corpos: o tempo nos meios de transporte cansa as pessoas; as grandes distâncias as obrigam a grandes deslocamentos e a ficar mais tempo fora de casa, o que supõe uma adaptação dos horários de alimentação, de repouso, de higiene pessoal.

Esses exemplos mostram que os cidadãos se disciplinam ou disciplinam seus corpos para viver nas cidades, mas que a cidade, por sua vez, também se molda por seus habitantes. Cidades, então, não são somente locais de mercado, de comércio, de trocas monetárias, de arquiteturas e planejamentos urbanos; são espaços de interações, de culturas, espaços onde a cultura se exprime em corpos.

\section{O ESFIRRAÇO DE COPACABANA}

A perspectiva socioantropológica que adotamos para analisar o corpo e as emoções fundamenta nosso olhar sobre a comida de rua. Assim, entendemos que o alimento não apenas nutre o corpo, mas situa-se também em uma esfera simbólica. A comida hierarquiza, distingue, reforça laços culturais, enfim, une ou separa sujeitos. Na situação que analisamos, os elementos de separação pelo etnocentrismo e de (re) união pelo evento chamado Esfirraço ficam claros. A construção das emoções em torno dos fatos narrados no jornalismo também é evidenciada.

Uma matéria publicada no site do jornal $O$ Globo sobre o evento teve início com o seguinte trecho: “'Posso te dar um abraço?' foi uma das perguntas mais ouvidas pelo refugiado sírio Mohamed Ali Abdelmoatty Ilenavvy, de 33 anos, neste sábado, em Copacabana". (RAMALHO, 2017) É com emoção, afeto e com referência a um gesto que une corpos que o texto jornalístico se inicia. A matéria segue explicando que 
o sírio-egípcio foi vítima de xenofobia e agressões verbais e que uma reunião aberta, festiva, na rua - realizada no sábado, dia 12 de agosto de 2017, às 9h, na Tenda Árabe, na esquina da Av. Nossa Senhora de Copacabana com Rua Santa Clara - recebeu apoio de pessoas da cidade e de seus arredores.

Duas semanas antes, o imigrante havia sofrido ameaças físicas e agressão verbal ao instalar sua barraca na importante avenida de Copacabana. O teor dos insultos proferidos referia-se à sua religião, ao fato de ser estrangeiro: "Sai do meu país! Eu sou brasileiro, nós somos brasileiros! Nosso país tá sendo invadido por esses homens-bomba, miseráveis, 'esquartejados', que mataram crianças, adolescentes. Justiça! São miseráveis", gritou um homem que o ameaçava com pedaços de pau, em vídeo que circulou pelas redes sociais ${ }^{1}$ e depois foi reproduzido em matérias na TV.

$\mathrm{Na}$ realidade, como outras reportagens divulgaram posteriormente, por trás da agressão estava o fato de as calçadas do bairro terem sido "loteadas" por grupos que cobram dos camelôs e vendedores ambulantes para que possam comercializar seus produtos. (WERNECK, 2017) Assim, o elemento inicial do conflito teria sido a recusa de pagamento dessa propina ou "pedágio". Uma razão econômica que levou à agressão e aos insultos de ordem etnocêntrica e xenofóbica. O estrangeiro aqui foi visto como ameaça (SCHÜTZ, 2003); foi estigmatizado. (GOFFMAN, 1980)

Diante desse quadro, promover o evento, comprar e consumir as esfirras e demais alimentos produzidos pelo imigrante foi, para um grupo de pessoas indignadas com a agressão, um modo criativo de apoiá-lo, de promover integração e reconhecimento. Os abraços, a aproximação física dos corpos para fotos selaram a aproximação. O evento gerou certa efervescência e um estar-junto (MAFFESOLI, 2000) em torno da comida. Pessoas se sensibilizaram, colocaram-se no lugar do estrangeiro e quiseram mostrar, para o olhar do outro, que brasileiros, cariocas, não se sentiam representados pelos agressores e suas ofensas.

1 Ver em: https://www.youtube.com/watch?v=f2tXhGWh1aU. 
Matéria do portal G1, publicada dois dias antes do evento, já tratava do Esfirraço. (MENDONÇA, 2017) Assim, a agressão, depois a convocação nas redes sociais e, finalmente, o evento propriamente dito foram tema de matérias - repercutindo as redes sociais que iniciaram a difusão do assunto. E, em setembro, quase dois meses depois dos xingamentos, outra matéria, no jornal O Globo, traria reportagem sobre o "loteamento" das calçadas de Copacabana. (WERNECK, 2017)

Mohamed foi fotografado junto às pessoas, abraçou, foi abraçado e beijado, apertou mãos de desconhecidos, apareceu em inúmeras selfies. Corpos e emoções em evidência selaram a paz entre as diferentes culturas. A compra e o consumo da comida de origem estrangeira marcaram o apoio. Segundo a matéria do site do jornal, o homem afirmou se sentir, naquele momento, "a pessoa mais feliz do mundo". (RAMALHO, 2017) Aqui, o papel das emoções extrapola a determinação de normas de comportamento social. Le Breton (2009) destaca o papel das emoções na construção das sociabilidades, representando a interpretação do aprendizado coletivo e da identificação do indivíduo com os outros.

A comida sírio-libanesa, ou parte dela, faz parte do que os brasileiros, habitantes de grandes cidades, como Rio de Janeiro, consomem. Nas festas infantis e em lanchonetes, esfirras e quibes fazem parte do cardápio em diversas versões e adaptações. O quibe, em especial, é comida de rua: é oferecido nos bares e botequins, é vendido nas feiras-livres nas barracas de pastel e caldo de cana, assim como o bolinho de aipim com carne - fritos indistintamente no mesmo tacho de óleo. Cadeias de fast-food como Habib's também exploram esse menu.

Partindo desse entendimento, o sucesso do evento não se deve somente ao cardápio oferecido - já amplamente conhecido. A que se deveu o sucesso do evento viabilizado pelas redes sociais? A uma empatia com alguém que foi vítima de uma injustiça, a alguém que está em uma situação de desigualdade social - por ser estrangeiro, estar deslocado, passar por dificuldades mesmo com o idioma -, pelos alimentos servidos serem já conhecidos e apreciados por uma parcela da população 
urbana. Pela oportunidade de estar-junto, de participar. Foi, provavelmente, o conjunto desses fatores que tornou o esfirraço um sucesso.

O êxito pôde ser acompanhado nas matérias publicadas nos diversos meios e veículos de comunicação, na discussão que se ampliou pelas diversas esferas da sociedade - mesmo a prefeitura, representando o Estado, se apressou para fornecer a documentação para a regularização da situação de trabalho do imigrante. Nas redes sociais, marcadamente no Facebook, os comentários dos leitores, usuários e respondentes ao apelo do evento são marca da discussão gerada. A imensa maioria dos comentários lidos diz respeito ao apoio ao vendedor, mas há também comentários contra mulçumanos, contra estrangeiros que tirariam o trabalho dos brasileiros, contra camelôs.

Na página do evento no Facebook, pode-se ler, por exemplo, um longo elogio ao evento e aos cariocas:

Que atitude bonita de vocês, cariocas. Na próxima visita ao Rio, irei degustar essa iguaria. Fiquei revoltado quando vi aquele ambulante com dois pedaços de pau nas mãos, proferindo insultos ao sírio. Instantaneamente surgiu uma empatia em relação à defesa do Mohamed. Naquele momento, desejei tanto estar na Cidade Maravilhosa, que me recebeu de braços abertos várias vezes, para me solidarizar e apoiar a permanência dele ALI, naquele local que ele escolheu para trabalhar. Benvindo ele sempre será... E que seja feliz em nosso país! Pelo que pude observar, a escolha dele em mudar de ponto foi muito melhor. Abraço forte a todos os cariocas e àqueles que agregaram esse sirio-brasileiro. Em homenagem a vcs cariocas sangue-bom, a música CARIOCAS, da gaúcha Adriana Calcanhoto. Quem ainda não a ouviu, é uma boa ideia. Começa assim: 'cariocas são bonitos, cariocas são bacanas.... (Marcílio Santiago, Ceará, 13 ago. 2017)

O autor do comentário se identifica como alguém do estado do Ceará, mas que em algum momento visitou o Rio. Seu ponto de vista é de fora, distante, contudo, de alguém que conheceu a cidade ou parte dela. O comentário mostra como, com as redes eletrônicas, o fato se ampliou para além dos limites de Copacabana e do Rio de Janeiro.

Além de comentários sobre a iniciativa de realização do evento, houve reações em relação à qualidade e ao preço dos alimentos produzidos pelo ofendido. Há elogios aos salgados oferecidos: "Gente, a esfiha dele 
é MARAVILHOSA. Massa que desmancha na boca e recheios muito bons!!! E muito barato. Uma cx com 8 custa 10,00. Vale muito". (Elizaida Diniz, 16 ago. 2017)

Contextualizando o evento e relacionando-o a outras datas importantes no calendário brasileiro, há também referências ao Dia dos Pais, celebrado no domingo seguinte ao esfirraço. Esse é um aspecto interessante, uma vez que o Dia dos Pais é uma data inventada - tanto no sentido antropológico quanto no sentido comercial -, sua comemoração não se dá na mesma data em diferentes países e nem é realizada em tantos países ocidentais ou ocidentalizados. Assim, quem deseja "feliz Dia dos Pais" para um estrangeiro, na realidade, o está inserindo, integrando ao calendário de efemérides brasileiro. De fato, este é o caso, uma vez que o usuário que faz o comentário o chama de "nosso egípcio-brasileiro": "Feliz Dia Dos Pais a todos, em especial o nosso egípcio brasileiro Mohamed Ali!". (Fabricio Rocha, 13 ago. 2017)

Se os comentários apontados até o momento mostram um ponto de vista pró-Mohamed - perspectiva reproduzida nas reportagens citadas -, essa não foi a única opinião sobre o fato. O evento e a situação do imigrante também geraram conflito e oposição. Algumas pessoas se manifestaram contra sua presença: "Absurdo, este cidadão esta ocupando as calçadas de Copacabana, fora ele e todos os outro camelos, que vendem mercadorias roubadas sem nenhuma comprovação de procedencia". (Guilherme Dias Carneiro, 13 ago. 2017)

Nesse comentário, o ponto de vista é contrário à presença de camelôs ocupando/privatizando as calçadas do bairro carioca - o que dificulta a passagem de pedestres, gera "desordem urbana", em certa perspectiva. O comentário acima gerou respostas contrárias à posição do autor:

E como vc sabe que as mercadorias são roubadas. Afff... a calçada de Copacabana não te pertence pelo q sabemos. (Fernanda Skm)

Quem disse que são mercadorias roubadas? Tem como provar? São pais de família que estão tentando ganhar a vida honestamente. Se não pode ajudar senhor Guilherme, melhor não atrapalhar quem já está sofrendo demais. Pro- 
cure um serviço voluntário pra fazer. Saia da sua zona de conforto e veja que os problemas são muito mais complexos do que imagina. (Cristina Moraes)

Depois dos comentários postados por diferentes usuários na página do Facebook, finalmente, ao final do dia, o interessado, Mohamed Ali, se posicionou sobre o evento e se expressou na rede social. O tom que adotou foi de expressão de reconhecimento, de agradecimento pela experiência vivenciada:

Boa noite para todos! Eu não consigo dormir de tão feliz!!!

O que aconteceu comigo hoje, vai ficar nas minhas lembranças pra sempre!

Com amor, nós podemos fazer esse mundo não ter guerra.

Não vou parar de ter esperanças. Sempre soube que nesse mundo, tem pessoas amáveis e carinhosas, mas não como os brasileiros

Amo todos vocês

Amo o Brasil!!!

(Mohamed Ali, 12 ago. 2019)

A manifestação pública das emoções do homenageado fazem retomar a formulação de Mauss (1969) a respeito da comunicabilidade coletiva das expressões afetivas: a pessoa faz mais do que manifestar seus sentimentos. Ela os manifesta para os outros, ou melhor, os manifesta para si mesmo exprimindo-os aos outros.

Nem todos os veículos de comunicação de caráter jornalístico abrem espaço para comentários de usuários - poderíamos fazer um paralelo entre os comentários e as antigas cartas dos leitores enviadas para as redações. Alguns veículos, no entanto, abrem esse espaço. $\mathrm{O}$ vídeo de uma matéria do programa da Rede Record de televisão Domingo espetacular, publicado no YouTube, gerou uma interessante reação. O usuário distribui a responsabilidade pelo conflito entre prefeitura e jornalistas: "O problema é que o prefeito dá licença de ambulante pra estrangeiro, mas não dá pra brasileiro. Esses jornalistas nunca dão a notícia por inteiro. cambada!". (Mario Rocha, ago. 2017)

Em todos esses comentários, desobrigados do valor informativo, as emoções ocupam espaço principal. Embora haja argumentos, são os sentimentos em relação ao fato social que prevalecem na interação. 
Finalmente, retomando os textos jornalísticos, a matéria do site de $O$ Globo, primeira citada neste artigo, termina como começou: com emoção. O texto apresenta uma fala do sírio-egípcio afirmando:

'Estou muito feliz. Muito mesmo. Sou a pessoa mais feliz do mundo hoje. E estou muito orgulhoso porque vivo no Brasil, amo todo mundo e fiquei muito surpreso com o movimento. Já perdoei aquele homem (o agressor)' - disse Mohamed, que não soube estimar quantos salgados vendeu neste sábado, mas afirmou que foi o dia mais lucrativo desde que chegou ao Rio, há três anos. (RAMALHO, 2017, grifo nosso)

A expressão das emoções resulta do modo como interpretamos fatos e situações e como reagimos. A reação deriva de um repertório ao qual o indivíduo foi exposto culturalmente ao longo da vida e cujos sentidos são reconhecidos e partilhados com o grupo social.

\section{CONSIDERAÇÕES FINAIS}

A difusão da notícia sobre a agressão ao vendedor ambulante estrangeiro de salgadinhos árabes, sua cobertura pela grande imprensa e propagação pelas redes sociais trouxe à tona o tema da comida de rua nas grandes cidades como uma possibilidade de abordagem interdisciplinar. Lidamos aqui com um fato social, um objeto do campo da Sociologia, da comunicação, dos estudos sobre cidade. Embora o cardápio possa parecer do campo da nutrição e da alimentação, ele expande-se para problemática de outras áreas também.

Como apontam o material jornalístico relativo à cobertura da situação estudada - os eventos de agressão, a campanha de solidariedade e a repercussão sobre um problema urbano, o loteamento ou privatização das calçadas de Copacabana por empresários informais e violentos - e os comentários dos usuários de redes sociais, as emoções ocuparam importante papel nas representações relacionadas ao caso do sírio. Defesa por parte da maioria que se expressou, ataque por parte de alguns usuários de redes sociais, abraços, beijos, selfies dos grupos são elementos que aparecem fartamente nos textos, fotos, comentários 
tornados públicos. São emoções expressas por meio do corpo: apertos de mão, abraços, beijos, aproximação corporal que dizem tanto culturalmente quanto as palavras.

As emoções aqui têm como atributo comunicar coletivamente a forma como interpretamos perdas, conquistas. Por isso, em uma perspectiva da Antropologia, nem sempre é possível traduzir o sentido de uma emoção ou sua expressão de um grupo social para outro que não domine o mesmo repertório cultural. (LE BRETON, 2009)

A situação estudada afirma, desse modo, nosso entendimento de precisarem o corpo, a alimentação e a cidade de múltiplas abordagens para uma análise mais complexa. O corpo e a alimentação, reafirmamos, são cultural e simbolicamente construídos. Imbricam-se com as questões das cidades porque são afetados por ela e as afetam. O que as pessoas comem nas cidades vai além da simples interpretação de uma escolha individual. As pessoas vão comer o que está disponível, o que elas podem pagar, o que podem transportar - e isso vai depender de quanto tempo precisam ficar fora de casa, quanto tempo gastam em transportes e deslocamentos diversos -, além do fator da oferta.

Muito antes do violento evento de rejeição ao vendedor sírio, salgadinhos de origem "árabe" já eram comercializados e apreciados em diversos espaços e situações no Rio de Janeiro. A agressão com termos xenofóbicos e fundamentada em disputa por território apenas ressaltou o preconceito de alguns em relação ao estrangeiro, ao "estranho", ao diferente, como Schütz aponta em seu livro Létranger. O evento organizado em uma rede social, sua divulgação pela mídia e a repercussão final mostraram que a metrópole é múltipla em suas opiniões e que a comida pode integrar, pode ser elemento de aproximação no espaço urbano.

Observa-se aqui, então, a emoção como uma categoria analítica que também pode dar conta do social: raiva gerou a agressão; solidariedade, afeto buscaram compensar a violência. Nesse caso, a expressão das emoções em torno do consumo efervescente e festivo de quibes e esfirras se mostrou uma rica forma de sociabilidade nas calçadas de Copacabana. 


\section{REFERÊNCIAS}

ATAQUE a refugiado sírio coloca em xeque a fama do brasileiro acolhedor. [S. l.: s. n.], 2017.1 vídeo (15 min. e 49 s.). Publicado pelo canal Domingo Espetacular. Disponível em: https://www.youtube.com/ watch?v=f2tXhGWh1aU. Acesso em: 17 nov. 2017.

BARBOSA, L. Feijão com arroz e arroz com feijão: o Brasil no prato dos brasileiros. Horizontes Antropológicos, Porto Alegre, v. 13, n. 28, p. 87-116, jul./dez. 2007.

CANCLINI, N. G. Imaginarios urbanos. 3. ed. Buenos Aires: Eudeba, 2007.

CASCUDO, L. C. História da alimentação no Brasil. 2. ed. Belo Horizonte: Itatiaia, 1983.

DURKHEIM, É. Les formes élémentaires de la vie religieuse: le système totémique en Australie. Paris: CNRS Editions, 2007.

GOFFMAN, E. Estigma: notas sobre a manipulação da identidade deteriorada. Rio de Janeiro: Jorje Jorge Zahar, 1980.

LE BRETON, D. Anthropologie du corps et modernité. 4. ed. Paris: PUF, 2005.

LE BRETON, D. As paixões ordinárias: antropologia das emoções.

Petrópolis: Vozes, 2009.

LE GOFF, J.; TRUONG, N. Uma história do corpo na Idade Média. 4. ed. Rio de Janeiro: Civilização Brasileira, 2012.

MAFFESOLI, M. Homo eroticus: des communions émotionnelles. Paris: CNRS Éditions, 2012.

MAFFESOLI, M. Le temps des tribus: le déclin de l'individualisme dans les sociétés postmodernes. 3. ed. Paris: La Table Ronde, 2000.

MAUSS, M. L'expression obligatoire des sentiments: rituels oraux funéraires australiens. In: MAUSS, M. Essais de sociologie. Paris: Ed. de Minuit, 1969. p. 81-88.

MAUSS, M. As técnicas corporais. In: MAUSS, M. Sociologia e antropologia. São Paulo: EDUSP, 1974. v. 2, p. 209-233.

MENDONÇA, A. V. Empresário faz vaquinha e convoca "esfihaço" em apoio a ambulante egípcio agredido em Copacabana. G1, Rio de Janeiro, 10 ago 2017. Disponível em: https://g1.globo.com/rio-de-janeiro/noticia/ empresario-faz-vaquinha-e-convoca-esfihaco-em-apoio-a-ambulanteegipcio-agredido-em-copacabana.ghtml. Acesso em: 14 nov. 2017. 
MILLER, W. I. The anatomy of disgust. Cambridge: Harvard University Press, 1997.

RAMALHO, G. Após "esfirraço", refugiado sírio pode ganhar food truck e fazer eventos fora do Rio. O Globo, Rio de Janeiro, 13 ago. 2017. Disponível em: https://oglobo.globo.com/rio/apos-esfirraco-refugiado-sirio-podeganhar-food-truck-fazer-eventos-fora-do-rio-21701207\#ixzz4v0Xs1dwe. Acesso em: 12 nov. 2017.

REZENDE, C. B. Mágoas de amizade: um ensaio em antropologia das emoções. Mana, Rio de Janeiro, v. 8, n. 2, p. 69-89, out. 2002.

ROCHA, E. P. G. O que é etnocentrismo? São Paulo: Brasiliense, 1984.

RODRIGUES, M. Cariocas fazem fila em "esfihaço" para apoiar refugiado sírio agredido em Copacabana. G1, Rio de Janeiro, 12 ago. 2017. Disponível em: https://g1.globo.com/rio-de-janeiro/noticia/cariocas-fazem-fila-emesfihaco-para-apoiar-refugiado-sirio-agredido-em-copacabana.ghtml. Acesso em: 12 nov. 2017.

SCHÜTZ, A. Létranger: un essai de psychologie sociale: suivi de L'homme qui rentre au pays. Paris: Allia, 2003.

SIMMEL, G. A metrópole e a vida mental. In: VELHO, O. G. (org.). O fenômeno urbano. 2. ed. Rio de Janeiro: Zahar, 1973. p. 11-25.

SIQUEIRA, D. C. O. Corpo, construção social das emoções e produção de sentidos na comunicação. In: SIQUEIRA, D. C. O. (org). A construção social das emoções: corpo e produção de sentidos na comunicação. Porto Alegre: Sulina, 2015. p. 15-36.

SIQUEIRA, D. C. O. Juventudes e cidades no videoclipe: o corpo como foco. Líbero, São Paulo, v. 15, n. 29, p. 51-58, jun. 2012.

SIQUEIRA, E. D.; SIQUEIRA, D. C. O. Destaque para a garota carioca: corpo, sociabilidade e comunicação na cidade. Porto Alegre: Sulina, 2017.

WAGNER, R. A invenção da cultura. São Paulo: Cosac Naif, 2010.

WERNECK, A. Os "donos" das calçadas: "Irmãos Metralha", suspeitos de agressão a sírio, controlam camelôs em Copacabana. O Globo, Rio de Janeiro, p. 9, 17 set. 2017. 



\section{Itinerarios alimentarios en contextos de precarización otras formas de comer, otras formas de vivir}

\section{INTRODUCCIÓN}

En el siglo XXI, la seguridad alimentaria continúa sin estar garantizada para ochocientos millones de personas en el mundo. (FAO; FIDA; PMA, 2015) En diversos países de África, Latinoamérica y Asia existen serias dificultades para alimentar a una parte de sus poblaciones, alentadas por la creciente inestabilidad de unos precios de los alimentos que son determinados por las corporaciones transnacionales y las reglas del comercio internacional, la falta de inversiones en los sistemas agrícolas locales o la destrucción de los mercados autóctonos. (GRACIA-ARNAIZ, 2012) 
Este fenómeno, con dimensiones y alcance muy distinto, también afecta a los denominados países del "primer mundo" en los que la pobreza alimentaria, como mostraremos aquí, no ha dejado de aumentar en la última década, favorecida por los efectos de la crisis económica global y la aplicación de políticas neoliberales que han puesto en jaque el estado de bienestar. (RICHES; SILVASTI, 2014) En España, dicha pobreza se ha afrontado mediante el soporte de diversas redes sociales, pero sobre todo por medio de una progresiva institucionalización y corporativización de la ayuda alimentaria (RICHES; SILVASTI, 2014) a través de los bancos de alimentos, los comedores populares o los supermercados sociales entre otros dispositivos, los cuales reproducen lógicas asistencialistas que si bien sirven para aliviar la falta de comida no resuelven el problema.

\section{LA PRECARIZACIÓN DE LA VIDA COTIDIANA}

En España, la "crisis" económica ${ }^{1}$ ha constituido un punto de inflexión que muestra no sólo las paradojas de unas políticas improvisadas, sino los límites de un estado de bienestar precario que ha dado al traste con derechos fundamentales considerados incuestionables. Ya no se puede o debe seguir hablando de las sociedades de la abundancia alimentaria en el mismo sentido que hasta hace poco lo han hecho sociólogos y antropólogos (POULAIN, 2002), ni afirmar sin relativizar que han disminuido las diferencias sociales en el consumo (PAKULSKI; WALTERS, 1996)

1 Una parte de las ideas aquí planteadas han sido previamente discutidas en Gracia-Arnaiz, M. (en prensa, 2017). "Otras formas de comer fuera de casa: itinerarios alimentarios en un contexto de creciente precarización". Este texto presenta una parte de los resultados de la investigación "Comer en tiempos de crisis: nuevos contextos alimentarios y de salud en España" (Plan Nacional I+D, CSO2012-31323, 2013-2015). De base etnográfica, el estudio incluyó tres niveles de análisis basados en la revisión bibliográfica, el tratamiento de fuentes documentales y estadísticas y el trabajo de campo de apoyo empírico en las principales ciudades de las comunidades de Cataluña y Murcia. Entrecomillamos el concepto de "crisis" porque el término ha sido utilizado con frecuencia para referirse a una situación de constreñimientos económicos sobrevenidos y pasajeros que una vez resueltos nos devolverán al punto de partida. Sin embargo, las particularidades de esta "crisis" hacen pensar que no estamos en un período de inestabilidad coyuntural producida por alteraciones socioeconómicas previsibles, sino ante un cambio estructural de tendencias dados los recortes aplicados por los gobiernos neoliberales en algunas sociedades europeas y sus consecuencias en la pérdida de derechos sociales y en el empeoramiento de las condiciones materiales de vida de millones de personas. 
particularmente en aquellos países cuyos sistemas productivos favorecen, cada vez más, el incremento de la disparidad entre ricos y pobres. El impacto de los recortes llevados a cabo ha hecho emerger las contradicciones y los límites de un sistema alimentario agroindustrial tan relativamente profuso en la producción de alimentos como cuestionable en su distribución y sostenibilidad, poniendo en evidencia la dualidad apuntada por Warde (1997), según la cual si bien, por un lado, es cierto que la oferta alimentaria es más flexible y particularizada que nunca, por otro, la clase social, cuyas fronteras son ahora más fluidas, continua siendo la principal variable explicativa de la heterogeneidad y desigualdad en el consumo de alimentos. Así pues, esta situación sugiere que los principales problemas de la "posmodernidad/posfordismo" no son únicamente los provocados por la abundante, diversa y no siempre nutritiva comida que el sistema agroalimentario actual produce, ni por la profusión discursiva-normativa o los múltiples particularismos alimentarios, sino también, en las sociedades industrializadas, los de garantizar el acceso regular a toda la población, pero especialmente a las clases populares, a alimentos saludables, culturalmente significativos y económicamente sostenibles. (GRACIA-ARNAIZ, 2014)

En 2014, una coalición formada por organizaciones civiles y grupos de investigación ${ }^{2}$ presentaron un informe en Naciones Unidas que ponía en tela de juicio que España estuviera cumpliendo con la obligación de dedicar el máximo de recursos disponibles para hacer efectivos los derechos sociales y garantizar la protección de los grupos de riesgo y exclusión mitigando así los impactos de la crisis económica, y recomendado, entre otras cosas, que el estado se abstuviese de favorecer medidas legislativas o de política pública que cuestionasen los derechos humanos y en particular el derecho de toda la población a una alimentación adecuada. En efecto, las razones que parecen estar cuestionando el derecho a la alimentación de un modo impensable hace apenas una década, tienen que

2 Información disponible en: http://observatoridesc.org/es/informe-vulneracion-del-derecho-alimentacion-espana-ante-naciones-unidas. 
ver con los cambios económicos, políticos y sociales promovidos por los gobiernos neoliberales (LAPARRA; PÉREZ, 2012) al poner en práctica "recetas" para reducir el gasto público, visto éste último como uno de los principales males de las economías capitalistas postindustriales. Afectada por las tensiones generadas por la economía mundial, entre 2008-2013 España se enfrentó a obstáculos singulares como la fragilidad del sistema bancario, el estallido de la burbuja inmobiliaria y la destrucción masiva de empleo, los cuáles debilitaron aún más su economía y pusieron en jaque a la administración del estado que optó por reforzar a la banca, reformar el mercado laboral, recortar derechos sociales y sanitarios, contener las pensiones y subir los impuestos directos e indirectos tales como el IRPF o el IVA. (NAVARRO, 2015)

La "crisis" ha afectado a toda la población pero los más pobres han perdido más que los más ricos, siendo las clases populares las que más han sufrido los efectos negativos de estas políticas. Entre 2008 y 2012, los ingresos medios de los hogares bajaron un $11 \%$, mientras que los sueldos más altos subieron en el mismo trienio un 2,4\%. (BOLAÑOS, 2014) Desde el punto de vista comparativo, la evolución de la pobreza y la exclusión social en España durante 2008-2014 ha sido más acentuada que el conjunto de la Unión Europea. (MSSI, 2014) Es el segundo país de la OCDE donde más ha descendido el salario mínimo en comparación con el salario medio (OCDE, 2014) y donde más ha crecido la desigualdad económica. Aunque las cifras macroeconómicas de 2015 han mejorado en algunos aspectos relativos a la tasa de desempleo, situándose en 20,90\% según la EPA, las condiciones de vida han empeorado para muchas personas. Los nuevos contratos han permitido bajar el número de parados, pero evidencian que el empleo continua siendo escaso, de peor calidad, con más temporalidad que antes, y lo que es más importante, con salarios que en muchas ocasiones no permiten salir de la pobreza. (AYLLÓN, 2015) En este sentido, estar empleado es compatible con ser pobre. De hecho, el $12 \%$ de personas con empleo están por debajo del umbral de la pobreza (CARITAS EUROPA, 2015), y aunque la tasa del desempleo ha disminuido en los dos últimos años, todavía hay más de 4 millones desempleados. 
(INE, 2016) En la UE, la tasa AROPE - que combina tres factores de desigualdad: renta, privación material severa y baja intensidad de trabajo en el hogar - era del 23,7\% en 2008, algo superior a la española, y si bien ha aumentado desde entonces, el incremento ha sido mucho más suave que el registrado en España (1,3 puntos porcentuales entre 2008-2012 frente a los 3,7 de España en el mismo período). Después de llevar dos años estancada en el 27\% (en 2011 y 2012), en 2014 la tasa aumentó dos puntos alcanzando el 29,2\%. Esto significa reconocer que más de 13 millones de personas en España son pobres, y entre ellas casi 3 millones son niños, de los cuales 840 mil son pobres crónicos.

Las nuevas formas de pobreza presentan realidades diversas: familias con los adultos desempleados, hogares unifamiliares con hijos menores, jubilados con pensiones reducidas o inmigrantes ilegales. Aparece un nuevo perfil de demandantes de ayuda compuesto por personas que procediendo con frecuencia de estratos medios o medios-bajos su vida cotidiana se ha fragilizado por la falta recurrente de recursos para subsistir. Ésta se corresponde con la noción de precarización ofrecida por Paugam (2000), la cual refleja una idea dinámica sobre aquello que, relacionado con la inestabilidad socioeconómica, se concibe como un proceso. No es necesario estar en la pobreza extrema para vivir la experiencia de la precarización. Un obrero o un pequeño comerciante pueden quedarse sin trabajo o perder la cartera de clientes y pasar por un periodo de inestabilidad económica y social. La precarización no remite solamente a un indicador monetario, sino también a los cambios producidos que suponen restricciones en el consumo, dificultades para pagar la vivienda, la hipoteca, los recibos de luz y gas, o para la adquisición de comida. Remite, en definitiva, a la idea de fragilización social, y es un continuum entre la integración y la exclusión. No obstante, también alude a la noción que defiende Lorey (2015), según la cual la precarización ya no es una situación excepcional. Ha sido instalada por el neoliberalismo y atraviesa la cotidianidad. Entraña dificultades, sí, pero también oportunidades para la búsqueda de nuevas formas de subsistencia que cuestionan la viabilidad del sistema. 


\section{CONTEXTOS DE CRISIS: LA POBREZA ALIMENTARIA}

El progresivo empobrecimiento provocado por las políticas económicas basadas en la austeridad ha tenido múltiples consecuencias en las maneras de vivir de los grupos más afectados y, en consecuencia, en sus maneras de comer. En términos de consumo, las personas con menos recursos disponen de menos oportunidades para adquirir alimentos variados y de calidad, y en menor frecuencia. Algunos autores señalan la pérdida del poder adquisitivo como la principal causa que explicaría la evolución del consumo de ciertos productos, especialmente los más baratos y menos saludables (ANTENTAS; VIVAS, 2014) y también del descenso del gasto de alimentación extradoméstico. Para Medina, Aguila y Fornons (2015), los datos ofrecidos por el Panel de Consumo Alimentario para Cataluña en el 2008, año en que se podría situar el inicio de la crisis, y comparándolos con los de 2012, ratifican la tendencia a la baja en el consumo de alimentos en general $(746,87 \mathrm{~kg}$ de alimentos per cápita en 2008 frente a 705,62 kg en 2012), con mayor afectación para el grupo de la leche (no así para los yogures y quesos, que bajan de manera moderada), las hortalizas y el pan, seguidos de la carne, las frutas, las patatas y el pescado. En sentido contrario, se observa un ligero aumento en el consumo de cerveza y de platos preparados. Con todo, hay que ser prudentes a la hora de interpretar los patrones dietéticos según esta fuente estadística, pues estos estudios sólo suelen mencionar la evolución del consumo per cápita de los grandes grupos de alimentos (por ejemplo, grasas y aceites), dentro de los cuales puede haber alimentos más o menos nutritivos o asequibles. Por otro lado, productos considerados altamente saludables, como las frutas y los vegetales, apenas han variado entre 2008-2014. (MARTIN, 2016)

Uno de los impactos más notables de la creciente precarización se concreta en las dificultades que las personas tienen que afrontar cuando tratan de cubrir las necesidades básicas, lo que se refleja en los indicadores recogidos en la Encuesta de Condiciones de Vida (2013): el $16,9 \%$ de los hogares manifiesta que es muy difícil llegar a final de mes, 
un 3,4\% más que en 2012 , mientras que en el $27 \%$ no se pueden permitir una comida a base de carne, pollo o pescado cada día. Por su parte, el último informe de FOESSA (FONAYET, ERASO, 2014), señala que el $16 \%$ de los españoles se vieron obligados a seguir una dieta inadecuada por falta de recursos económicos. Las personas que ven limitados sus recursos tratan de reducir gastos, y ello incluye la alimentación. Esta reducción del gasto puede alcanzarse minimizando las sobras, incrementando la compra de productos de marca blanca, o priorizando el precio como principal criterio para seleccionar y preparar las comidas. (GRACIA-ARNAIZ, 2014) Si con estas medidas no es suficiente, entonces buscan ayuda fuera de casa.

En relación con estas dificultades, las políticas gubernamentales de los últimos cinco años han sido contradictorias. Por un lado, han recortado prestaciones sociales que han aumentado la pobreza, y por otro han tenido que incrementar o idear dispositivos y programas para amortiguar la creciente inseguridad alimentaria. (KRAMER; GRACIA-ARNAIZ, 2015) Actualmente, el Plan de Ayuda Alimentaria de la Unión Europea (UE), co-financiado con fondos comunitarios y estatales, es el programa de mayor alcance que ofrece este tipo de ayuda en España. En 2015, a través de este plan se compraron 115 millones K/l. de alimentos como arroz, tarritos infantiles, cereales infantiles, leche de continuación en polvo, garbanzos, alubias, leche entera UHT, aceite de oliva, conservas de atún, espaguetis, tomate frito en conserva, crema de verduras deshidratada, galletas, judías verdes en conserva y fruta en conserva sin azúcar añadido. Estas acciones se acompañan del programa de retirada de fruta/verdura para ser distribuida gratuitamente. Si en 2010 el gobierno compró 63 millones k/l de alimentos, en 2015 la cifra casi se ha duplicado.

Las organizaciones caritativas y civiles han sido las principales gestoras de las ayudas alimentarias que han llegado a las personas en situación de precarización. Entidades de estructura supranacional como el Banco de Alimentos, Cruz Roja o Cáritas han acometido acciones de almacenamiento y distribución de productos básicos procedentes de excedentes del sector agroindustrial o donaciones particulares. Las dos últimas, en colaboración 
con las administraciones locales, han desarrollado también otros programas como los bonos sociales para la adquisición de alimentos o los comedores y supermercados sociales. Un ejemplo de estos dispositivos dispuestos en las principales ciudades son las tarjetas-monedero que permiten comprar los alimentos en supermercados y establecimientos comerciales sin visibilizar el perfil de demandante y evitar así su estigmatización:

dignificar la ayuda alimentaria, promover que las personas que se han empobrecido puedan seguir comprando en los establecimientos donde lo hacían normalmente y que sean ellas mismas las que decidan qué alimentos les hacen falta para que su alimentación sea equilibrada, suficiente y adaptada a sus necesidades. (CÁRITAS DIOCESANA DE BARCELONA, 2015)

La administración pública, por tanto, ha optado por afrontar el problema de pobreza alimentaria reforzando el papel de estas organizaciones, su institucionalización y corporativización. Según los datos proporcionados por la FESBAL (2014), la Federación Española de Banco de Alimentos, en 2014, recogió millones de kilos de alimentos; esta cifra supone un incremento del $50 \%$ con respecto a la pasada edición.

Se desconoce, sin embargo, las dimensiones sociales y sanitarias de este problema. Al margen de los numerosos monográficos sobre la pobreza y exclusión social que se han ido produciendo durante estos últimos años por diferentes organizaciones y observatorios (Fundación FOESSA, Cáritas, Cruz Roja...), en España no se ha elaborado ningún informe oficial o encuesta específica sobre el hambre, la inseguridad y ayuda alimentaria, como recientemente han hecho otros países europeos (Feeding Britain, 2015-2016 en Reino Unido o Etudes ABENA para Francia). Ni siquiera el "Barómetro de la Seguridad Alimentaria" llevado a cabo por la Agencia Catalana de Seguridad Alimentaria de Cataluña desde 2008 hasta 2015 ha incorporado nuevas variables que vayan más allá de recoger datos sobre conocimientos nutricionales, hábitos y percepción del riesgo. ${ }^{3}$ Desafortunadamente, no disponemos de

3 Disponible en: http://www.gencat.cat/salut/acsa/html/ca/dir3059/index.html. 
diagnósticos precisos sobre el alcance de este fenómeno porque en realidad no existe consenso sobre su naturaleza. Tampoco hay herramientas metodológicas que hagan mediciones directas de esta cuestión, y muchos de los datos disponibles proceden de fuentes secundarias.

Lo que han hecho algunas instituciones caritativas o humanitarias, como la Cruz Roja, es adoptar el término de "seguridad alimentaria" aceptado por la FAO y utilizado en la esfera de la cooperación al desarrollo y la emergencia humanitaria, entendiendo por seguridad alimentaria el derecho a la alimentación, es decir,

a tener acceso de forma individual y/o colectiva, de forma regular y permanente, a una alimentación adecuada y suficiente, y a los medios necesarios para producirla, de forma que se corresponda con las tradiciones culturales de cada población y garantice una vida física y psíquica satisfactoria y digna de las personas. (FAO, 2011)

Según esta institución, en la actualidad más de 2,5 millones de españoles dependen de los recursos sociales públicos y/o privados para poder comer diariamente. (CÁRITAS ESPAÑOLA, 2013) Un estudio realizado por Cruz Roja en Cataluña entre familias usuarias de programas contra la pobreza, muestra que el $29,5 \%$ de las personas con niños a cargo perciben que sufren inseguridad alimentaria leve, el 40,7\% moderada y el 21,7\% severa. (CREU ROJA, 2015) El 60,6\% de las familias no tienen una dieta óptima - el 54,4\% deberían mejorar su dieta y el 6,2\% de muy baja calidad -, y más de la mitad de las familias asegura que su alimentación proviene sobre todo de donaciones de entidades sociales y ayudas de familiares y amigos.

Estas ayudas alimentarias se han incorporado al conjunto de nuevas y viejas estrategias de abastecimiento, distribución y consumo entre las personas más empobrecidas (GRACIA-ARNAIZ, 2014), las cuales son muy semejantes a las llevadas a cabo en otros países europeos. (CAPLAN, 2016; SUTTON, 2014) Se trata de variaciones respecto a los lugares de compra, tipos y frecuencia de productos adquiridos o marcas elegidas buscando los más baratos para gastar menos; a la comensalidad, 
disminuyendo las comidas hechas en restaurantes o bares y las celebraciones en casa; a las formas de preparar los menús, evitando cocinar platos que requieren mucha energía y, particularmente, a la cantidad y tratamiento de las sobras, procurando un mayor ajuste entre lo comprado y consumido o minimizar el desperdicio o reciclar lo que se sobra. También se han cambiado las maneras de pensar la comida, entendiéndose como un bien de acceso limitado e incierto que hay que racionalizar, proteger y redistribuir. La necesidad ineludible - aunque flexible de comer para subsistir hace que se busquen todos los recursos posibles.

Aunque se trata de sujetos heterogéneos en origen, trayectorias y expectativas, nuestro estudio muestra cambios sustantivos en las prácticas alimentarias en general, aunque formas de abastecimiento constituyen el ámbito donde mejor se recogen las tensiones provocadas por las dificultades sobrevenidas. Al margen de lo que se puede adquirir en las tiendas, entre las personas con menos recursos, el abastecimiento de comida se produce a través de la asistencia social - comedores públicos, becas, tarjetas-monedero, despensas -, de recoger las sobras de restaurantes, supermercados o contenedores de basura, de recurrir a los repartos de alimentos en las calles, de cultivar huertos, de practicar la mendicidad e incluso al hurto en establecimientos o mercadillos. Por ejemplo, "comer en/de la calle", y en particular, de los restos/desperdicios constituye una práctica relacionada tanto con la precarización económica como con la toma de conciencia de que la comestibilidad puede ir más allá de los espacios convencionalmente "seguros" de los establecimientos que venden comida. (MONSERRAT, 2015)

\section{ITINERARIOS ALIMENTARIOS: COMER “FUERA DE CASA"}

Como hemos ilustrado en trabajos anteriores, la partida alimentaria es la más flexible del presupuesto personal familiar. (GRACIA-ARNAIZ, 1996) Ciertamente, las personas deben comer para subsistir, pero cómo lo consiguen, y cómo cubren esas necesidades depende, en buena medi$\mathrm{da}$, de las prioridades y dificultades que tienen que afrontar diariamente. 
Las personas que han vivido procesos rápidos de precarización han visto reducir su capacidad adquisitiva hasta el punto de que no pueden acceder a los bienes esenciales. El desempleo, el fin de las prestaciones sociales o el tener que hacer frente a un préstamo hipotecario suelen referirse como las principales causas que motivan a las personas a buscar soporte alimentario. (EGBE, 2015)

Si por un lado, los sentimientos de impotencia y vergüenza ante los apremios cotidianos han sido reiteradamente relatados por los informantes, por otro también han reconocido casi unánimemente que se consideran afortunados por haber encontrado soporte en diferentes lugares y personas:

Al principio no sabes a qué puerta llamar, pero una vez dejas la vergüenza en casa, te informas de las posibilidades que hay y empiezas a preguntar. Primero en el CAP buscas a la asistenta social, vas al Ayuntamiento y explicas tu caso. Te acercas a Cruz Roja, o la parroquia también, depende. Te pueden dar una despensa de emergencia, pero suelen analizar tu caso y luego te dicen a qué puedes optar, con quéfrecuencias, donde puedes ir a recoger producto, $y$ vas haciendo.... (María, 45 años)

En efecto, las diferentes administraciones han ido ampliando o desarrollando diferentes formas de ayuda que actúan como una especie de "válvula de seguridad moral" (POPPENDIECK, 1998), mediante las cuales se trataría de cubrir las necesidades nutricionales de los grupos más desfavorecidos, aliviando la presión social que genera al Estado y las administraciones publicas pensar que entre la ciudadanía hay gente hambrienta. Estas instituciones se plantean como un logro moral, pues ponen en funcionamiento los valores de solidaridad/altruismo de las miles de entidades donantes y distribuidoras de alimentos y de las personas voluntarias que participan. Se trataría, en cualquier caso, del triunfo de una caridad vertical y una solidaridad no-crítica, pues aquello que se dona o regala no pretende modificar las causas que producen la pobreza, sino aliviarla. Un ejemplo es el papel adquirido por los bancos de alimentos, que se abanderan como la institución capaz de hacer el mejor uso posible de los excedentes alimentarios, evitando el 
despilfarro, alimentando a los grupos más desfavorecidos y ayudando a las empresas a aumentar su responsabilidad social y marketing solidario. (MONTAGUT; GASCÓN, 2014)

Al margen de la capacidad que tienen esas instituciones de poner en circulación alimentos procedentes de la agroindustria y las donaciones privadas y hacerlos llegar a los más pobres, nos interesa enfatizar que éste es un recurso entre otros. Los itinerarios alimentarios no se acaban con los recursos caritativos, pues las personas tratan de resolver la falta de acceso regular a la comida recurriendo a diversos interlocutores y tácticas. Los informantes explican que unas de las primeras medidas adoptadas para gastar menos en comida ha sido, junto el aprovechamiento de las sobras, comprar productos de marcas blancas y evitar caprichos, y hacer platos sencillos y de cocción rápida. Pero sobre todo, dejar de salir a comer fuera. Llama la atención, al menos relativamente, la escasa comida que hay en las despensas de quienes reciben ayuda alimentaria $y$, por el contrario, la cantidad de veces que algunas personas salen del domicilio para comer. En los casos de precarización extrema, numerosas comidas no están resolviéndose en casa. En estos casos, se opta por estrategias que no siendo necesariamente nuevas o desconocidas sí que representan un modo muy distinto de "comer fuera", ya no como sinónimo de hacerlo por razones de trabajo o tiempo libre, sino porque fuera se encuentran diversos recursos que no requieren emplear sus cocinas, en algunos casos inservibles por falta de energía.

Una parte significativa de los informantes cuentan que desde que sus condiciones de vida han empeorado están comiendo menos en casa, y están cocinando poco. Explican que ya no gestionan su presupuesto familiar como solían hacerlo antes de que su vida se precarizara, cuando tenían uno o dos salarios estables y pleno empleo. Ninguno de ellos había pensado antes que iba a encontrarse en esa situación; ninguna madre pensó que tuviera que saltarse una o dos comidas al día para garantizar la alimentación de sus hijos, o comer menos por imposición: "reparto lo que hay, y voy de más a menos, primero mis hijos, después mi marido y yo la última. Si tengo hambre como más pan... y bebo más agua. Se hincha en el 
estómago y te calmas. (Carmen, 49 años) La falta de ingresos y recursos estables o muy bajos, las demandas de imponderables como pagar recibos de gas, luz o vivienda, les hace "improvisar" en muchos ámbitos, y también en el terreno alimentario:

yo fui a buscar allí donde creía que me podían ayudar, primero al ayuntamiento, pero la verdad no sabía por dónde empezar. Recuerdo la vergüenza que pasé con la recogida de la escuela, preguntándole a la maestra de mi hijo donde iban a parar esas bolsas de comida que se amontonaban cada día en la entrada y si yo podía conseguir alguna. (Rosa, 37 años)

Sus estrategias, en este sentido, se diversifican: no sólo consisten en buscar alimentos para llevar a casa, sino en comer donde sea posible. Además, estas estrategias son variables dependiendo de cada situación particular, en función de si las personas viven solas o hay niños pequeños, si son mayores, hombres o mujeres. Los grupos que han establecido itinerarios más complejos son las familias con menores a su cargo. Las responsables de la alimentación diaria, generalmente mujeres, dicen que los alimentos no perecederos que les dan a través de las asociaciones caritativas no cubren sus necesidades: "comemos muchos hidratos, pero poca proteína y vitaminas no sé, porque mucha fruta o legumbres que comemos son de lata". (Elisa, 32 años) Disponen de pasta y arroces de forma habitual, de leche y de atún, pero sin embargo, la fruta, la verdura, huevos y carnes los reciben con mucha menos frecuencia.

Los informantes que comen fuera de casa, lo hacen por diferentes motivos y de distinto modo. Una posibilidad es seguir comiendo en otros "hogares". Algunas familias han accedido a pisos gestionados por instituciones caritativas o habilitados por los ayuntamientos para que allí se pueda cocinar, e incluso comer. En estos hay un almacén con alimentos no perecederos (pasta, arroz...), y los usuarios llevan los perecederos, a veces comprados, otras obtenidos en bancos de alimentos o con los cheques de supermercado. Tienen tres horas asignadas a la semana, y se organizan para cocinar. Suelen hacer platos sencillos y así optimizar el poco tiempo disponible. Hacen lo más rápido, y varios platos a la vez: 
pasta con paté o atún; arroz blanco/a la cubana; sopas de verduras deshidratadas o de pasta/arroz en invierno. Las legumbres de latas se sofríen con ajos, o guisan con patatas u otras hortalizas si se tienen. En algunos casos, se puede comer ahí mismo, aunque la mayoría se lleva las fiambreras para casa. En uno de ellos, cada quince días se hacen talleres de cocina con cocineros voluntarios enviados desde el ayuntamiento. Estos les enseñan a hacer comidas sanas/baratas/buenas, parecidas a las del recetario publicado por la Cruz Roja en $2015^{4}$ donde aparecen propuestas de comidas de menos de 1 euro elaboradas por reconocidos chefs dispuestos también a compartir sus conocimientos con los pobres.

En el caso de que en el grupo doméstico haya hijos menores, la comida del mediodía que antes se hacía normalmente en casa, ahora, si se ha accedido a una subvención total o parcial del menú, se resuelve en el comedor escolar y, por tanto, fuera del hogar también. Hay niños que también realizan el desayuno y la merienda en la escuela. Este programa de ayuda se dirige a las familias con menos recursos y está organizado desde las AMPAS de algunos centros de los barrios populares. Las familias agradecen esta posibilidad porque dicen que así están seguras de que " $a l$ menos mis hijos hacen una buena comida al día”. (Fina, 31 años)

Otra forma de comer fuera de casa entre las personas emancipadas consiste en "regresar" al hogar de padres y madres. En España hay muchos jubilados acogiendo a sus hijos y nietos; cocinando con lo que sus hijos obtienen de donaciones (si las han pedido y no las consumen en su casa) o comprando comida con el dinero de sus pensiones: "y yo que me quejaba porque mi pensión no llegaba a los 800 euros, pues ahora con ella comemos todos, nosotros y mis hijos y nietos". (María, 72 años) Acudir a la casa natal para comer es percibida como una posibilidad menos vergonzante: "me evita la vergüenza de tener que pedir comida por ahí, lo prefiero mil veces antes que un comedor social”. (Marta, 41 años) Pero no solo se

4 En Cataluña, la Cruz Roja ha presentado el recetario de cocina "Para comer bien, bueno y barato" que cuenta con la colaboración de Nestlé, disponible en: http://www.creuroja.org/AP/ cm/4882P235L8/La-Creu-Roja-presenta-un-receptari-d-apats-saludables-a-menys-d-1-de-cuiners-catalans-de-gran-renom.aspx. 
trata de vergüenza. Reconocen que es más cómodo y emocionalmente, si no hay discusiones, más reconfortante. Además de no estar sujetos a horarios tan inflexibles, pueden comer platos familiares que además suelen responder a sus gustos: "mi madre siempre me pregunta ¿hoy que os hago?, y sabe lo que nos gusta a cada uno y lo que no. Pero su cocina no es un restaurante, está claro, así que nos adaptamos. El caso es comer caliente todos y con los tuyos". (Marta, 41 años)

Acudir a un comedor social es otra forma habitual de comer fuera, aunque no está al alcance de todos los informantes. A pesar de que su número ha aumentado desde 2009 en muchas ciudades, y se dan más servicios diarios, el acceso suele producirse por derivación de los servicios sociales. Hay informantes que lo consideran como una opción más entre otras posibilidades. Suele cubrir una misma comida, sea la del mediodía o el desayuno, aunque en Barcelona se ha abierto un comedor social en horario nocturno. Puede ser un recurso para toda la familia, pero en la mayoría de casos asisten parejas de personas mayores o en solitario. Los hay gestionados por las parroquias, las autoridades locales o las organizaciones civiles y cuentan con personal contratado y voluntariado. (KRAMER; GRACIA-ARNAIZ, 2015) El almuerzo prácticamente se prepara con los productos procedentes de donaciones del banco de alimentos y donaciones privadas. Además de mantener la estructura tripartita de la comida (primer plato, segundo y postres), se intenta combinar y preparar los alimentos mediante procesos que repliquen recetas más o menos habituales y culturalmente aceptables (fideos a la cazuela, paella, estofado de carne, cocido etc.). Esto no significa necesariamente que se cumplan las expectativas y deseos de los comensales. La acogida se percibe dialécticamente. Se mezclan las emociones de agradecimiento por el acogimiento y la posible comensalía "encontrada", junto con las de pérdida de autonomía sobre las decisiones alimentarias y satisfacción de gustos. De hecho, los comensales tienen poca (o ninguna) autonomía para decidir "qué", "cuanto", "dónde", "cuándo" y "con quién” comer.

Otras formas de comer fuera de casa consiste en acudir a los bares a desayunar o comer donde saben que hay un Café pendiente o una Comida 
pendiente, los cuales se identifican con logos específicos. El cliente paga uno o dos cafés o comida, además de lo que se toma. El usuario puede elegir café con leche, bocadillo, pasta, zumo. Entre nuestros informantes, sólo tres hombres reconocen utilizar este recurso y lo hacen esporádicamente, porque no siempre "alguien se acuerda de ti". (Luis, 53 años)

Finalmente, comer en todos estos espacios puede ser simultáneo con el consumo de alimentos recogidos en establecimientos destinados a la venta de comida u obtenidos en el reparto en la calle realizado por organizaciones humanitarias o agrupaciones vecinales en puntos concretos de los barrios de la ciudad. Con todo, se trata de prácticas que a veces han sido prohibidas por la administración local o regional al no contar con el suficiente control sanitario. Algunas de las personas que habitualmente recurren a estos dispositivos son aquellas que antes de la crisis ya no tenían un domicilio fijo, aunque cada vez más están siendo frecuentados por sujetos que nunca habían acudido con anterioridad. En general, pedir comida en los establecimientos o recoger la que se reparte en la calle es visto como una posibilidad más para incrementar sus escasos recursos. Los informantes se saben las horas/dias/lugares donde se distribuyen comidas, las cuales suelen repartirse por la noche o a primera hora de la mañana, coincidiendo con el desayuno. En Barcelona se ha editado una guía para informar sobre la localización de estos dispositivos, con mapas de ubicación, horarios y tipo de servicios ofrecidos. ${ }^{5}$ En estos lugares se reparten normalmente bocadillos de tortilla, queso o jamón, algunas frutas, sopas calientes o cafés con leche y pastas.

Paralelamente, mujeres y hombres también explican que visitan los bares, supermercados y tiendas de comida, pastelerías o cafeterías del barrio para recoger las posibles mermas o alimentos. Se trata de restos de pasteles o pan no vendidos, tapas, platos cocinados del menú o paquetes de alimentos cuyo envase se ha estropeado. Estos comercios suelen incluir la comida sobrante en bolsas o tuppers de plástico o cajas de cartón.

5 Es el caso de la guía publicada por parte de la Comunitat de Sant’Egidio para la ciudad de Barcelona, disponible en: http://www.santegidio.org/documenti/doc_1069/Guia_ON_2016_def.pdf. 
Otras veces, y cuando se trata de una práctica sistemática, son los informantes los que llevan sus propios receptáculos. Otras iniciativas relacionadas con la distribución gratuita de comida son las tiendas/bancos de alimentos organizados por comunidades de vecinos en los barrios más deprimidos de la ciudad. Las tiendas dicen que no dan abasto repartiendo alimentos entre religiosas, voluntarios de ONG y usuarios: " Aquí ya no se tira nada!". (vendedor de supermercado, 2A) En general, las personas pueden optar por comerse estos alimentos en la misma calle, "depende del hambre que tenga o del tiempo que haga" (Enric, 52 años), o a veces se los llevan a su casa para cocinarlos y/o compartirlos con otros miembros del grupo, o simplemente para consumirlos en otro momento del día.

En la calle se encuentran personas que recurren a las sobras por necesidad con aquellas otras que lo hacen por su ideología anticonsumista. Estas últimas son quienes, a su vez, acostumbran a estar en la organización de las disco soup, cuyo objetivo es apropiarse ocasionalmente del espacio público (plazas, mercados, hospitales) para hacer una gran comida reivindicando la reducción del despilfarro alimentario. Durante el trabajo de campo, asistimos en noviembre de 2014 al Gran Dinar Barcelona, organizada en el barrio de El Raval por la Plafatorma "Aprofitem els Aliments". Con la colaboración de más de 150 voluntarios se cocinó para 4 mil personas. Si bien es cierto que por su carácter esporádico no suponen una fuente regular de comida entre nuestros informantes, su participación es socialmente relevante. Se trata de comidas cuyo objetivo es mostrar que otras formas de comer más baratas, saludables y sostenibles son posibles. Suelen ser organizadas por gente muy crítica con el sistema agroindustrial global, especialmente en lo relativo al despilfarro y costes medioambientales. Coincidiendo con la crisis económica, estos activistas han incorporado en sus reflexiones los efectos de la progresiva precarización económica de la población. Defienden la democracia horizontal y la necesidad de buscar otras alternativas frente a la pobreza alimentaria que no reproduzcan las lógicas asistencialistas. Algunas de estas plataformas tienen como objetivo concienciar a las personas más vulnerabilizadas por el sistema de la necesidad de cambiar las reglas del juego invitándolas a participar 
activamente en proyectos generadores de recursos en sus comunidades, aprendiendo a producir alimentos (huertos sociales), o a rescatar y reutilizar alimentos producidos pero desconsiderados como comestibles. Se persigue, en cualquier caso, responder a las políticas económicas que están dificultando su derecho a la alimentación.

\section{CONCLUSIÓN}

Todas estas maneras de "comer fuera" (comedores sociales, casas de familiares, talleres culinarios, calle, cooperativas vecinales) constituyen ejemplos ilustrativos acerca de cómo las nuevas situaciones sociales condicionan las opciones alimentarias de los más pobres. Uno de los aspectos más importantes de esta crisis económica es precisamente la disminución de la capacidad de obtener alimentos de forma regular y autónoma entre personas en situación de precariedad económica, lo que ha llevado a reaparecer términos como "escasez", "comer lo que se puede" o "saltar comidas" en su lenguaje cotidiano. En el actual contexto de incertidumbre, evidencian que estas personas han de buscar recursos en diferentes lugares y gestionar el acceso a la comida interpelando a la ayuda de instituciones e interlocutores diversos. Con los alimentos que compran, se les da, o se encuentran de una u otra manera, tratan de crear o reproducir comidas que sean aceptables personal y socialmente. Algunas de estas soluciones evidencian experiencias de sufrimiento pues a menudo el pedir comida o buscarla entre las mermas se acompañan de sentimientos de vergüenza y culpa, pero otras implican una respuesta alternativa a las políticas económicas que están cuestionando el derecho a la alimentación como nunca antes se había hecho desde la transición democrática, pues superan las habituales formas de asistencia promovidas desde las entidades caritativas. Remiten, en su conjunto, a los modos en que este país ha institucionalizado/corporatizando las formas de seguridad alimentaria (solidaridad no-crítica), las cuales coexisten con otras redes sociales de soporte las cuales están asumiendo iniciativas de apoyo que deberían ser responsibilidad de los estados que sistematizan la precarización como forma de vida. 


\section{REFERENCIAS}

ANTENTAS, J. M.; VIVAS, E. Impacto de la crisis en el derecho a una alimentación sana y saludable. Gaceta Sanitaria, Barcelona, v. 28, p. 58-61, 2014. Suplemento 1.

AYLLÓN, S. Infancia, pobreza y crisis económica. Barcelona: Obra Social La Caixa, 2015. (Colección Estudios Sociales, n. 40).

BOLAÑOS, A. España sufre la crisis más desigual. El País, Madrid, 2014. Disponible en: https://elpais.com/economia/2014/06/19/ actualidad/1403175466_879515.html. Acceso en: 22 jan. 2015.

CAPLAN, P. Big society or broken society?: Food banks in the UK. Anthropology Today, Hoboken, v. 32, n. 1, p. 5-9, 2016.

CÁRITAS DIOCESANA DE BARCELONA. Cáritas implementará la tarjeta barcelona Solidaria para alimentos a las familias en toda la demarcación. Barcelona, 16 enero 2015. Disponible en: https://blog.caritas.barcelona/es/ ayuda-a-necesidades-basicas/caritas-implementara-la-tarjeta-barcelonasolidaria-para-alimentos-a-las-familias-en-toda-la-demarcacion/. Acceso en: 22 jan. 2015.

CÁRITAS ESPAÑOLA. VIII Informe del Observatorio de la Realidad Social. Madrid, 2013. Disponible en: http://www.caritas.es/publicaciones_ download.aspx?Id=4706. Acceso en: 22 jan. 2015.

CARITAS EUROPA. Poverty and Inequalities in the rise. Brussels, 2015. Disponible en: http://www.caritas.eu/sites/default/files/ caritascrisisreport_2015_en_final.pdf. Acceso en: 13 dez. 2015.

CREU ROJA. L'accès de la infància a l'alimentació saludable. Barcelona: Observatori de Vulnerabilitat, 2015.

EGBE, M. E. Human agency at work: the case of food insecurity in SubSahara African immigrant population in Tarragona. In: OBSERVATORIO DE LA ALIMENTACIÓN, 2015, Barcelona. Analess [...]. Barcelona, 2015. p. 408-501.

FAO. Una introducción a los conceptos básicos de la seguridad alimentaria. Roma, 2011. Disponible en: http://www.fao.org/3/al936s/a1936s00.pdf. Acceso en: 13 dez. 2015. 
FAO; FIDA; PMA. El estado de inseguridad alimentaria en el mundo:

cumplimiento de los objetivos internacionales para 2015 en relación con el hambre: balance de los desiguales progresos. Roma, 2015. Disponible en: http://www.fao.org/3/a-i4646s.pdf. Acceso en: 13 dez. 2015.

FESBAL. Gran recogida nacional de alimentos 2014: un éxito de la generosidad de los españoles. Madrid, 2014. Disponible en: https://www. fesbal.org/gran-recogida-nacional-de-alimentos-2014-un-exito-de-lagenerosidad-de-los-espanoles/. Acceso en: 19 jul. 2019.

FONAYET, F. V.; ERASO, A. B. La pobreza en España desde una perspectiva de género. Madrid: Fundación Foessa, 2014. Disponible en: http://www.foessa2014.es/informe/uploaded/documentos_ trabajo/15102014141447_8007.pdf. Acceso en: 3 mar. 2015.

GRACIA-ARNAIZ, M. Comer en tiempos de "crisis": nuevos contextos alimentarios y de salud en España. Salud Pública de México, Cuernavaca, v. 56, n. 6, p. 648-653, nov./dic. 2014.

GRACIA-ARNAIZ, M. La faim dans le monde. In: POULAIN, J. P. (dir.). Dictionnaire des cultures alimentaires. Paris: PUF, 2012.

GRACIA-ARNAIZ, M. Las paradojas de la alimentación contemporánea. Barcelona: Icaria, 1996.

INSTITUTO NACIONAL DE ESTADÍSTICA - INE. Encuesta de Condiciones de Vida (ECV): resultados definitivos: año 2013. Madrid, 2014. Disponible en: http://www.ine.es/prensa/np844.pdf. Acceso en: 13 dez. 2015.

INSTITUTO NACIONAL DE ESTADÍSTICA - INE. Encuesta Población Activa (EPA): cuarto trimestre de 2015. Madrid, 2016. Disponible en: http:// www.ine.es/daco/daco42/daco4211/epa0415.pdf. Acceso en: 13 dez. 2015.

KRAMER, F. B.; GRACIA-ARNAIZ, M. Alimentarse o nutrirse en un comedor social en España: reflexiones sobre la comensalidad. Demetra: Alimentação, Nutrição \& Saúde, Rio de Janeiro, v. 10, n. 3, p. 455-466, 2015.

LAPARRA, M.; PÉREZ, B. (coord.). Crisi i fractura social a Europa: causes i efectes a Espanya. Barcelona: La Caixa Obra Social, 2012.

LOREY, I. State of insecurity: government of the precarious. Londres: Versobooks, 2015.

MARTIN, V. Cincuenta años de alimentación en España: principales cambios en la demanda de alimentos y bebidas. Distribución y Consumo, Madrid, v. 3, p. 66-88, 2016. 
MEDINA, F.; AGUILAR, A.; FORNONS, D. Alimentación, cultura y economía social: los efectos de la crisis socioeconómica en la alimentación en Cataluña (España). Sociedade e Cultura, Goiânia, v. 18, n. 1, p. 55-64, 2015. MONSERRAT, M. A. Del junk food, al food from the junk: comer "de" y "en" la calle en tiempo de crisis. In: OBSERVATORIO DE LA ALIMENTACIÓN, 2015, Barcelona. Analess [...]. Barcelona, 2015. p. 1816-1834.

MONTAGUT, X.; GASCÓN, J. Alimentos desperdiciados: un análisis del derroche alimentario desde la soberanía alimentaria. Barcelona: Icaria, 2014. MSSI. Plan de Acción para la Inclusión Social 2013-2016. Madrid, 2014. Disponible en: http://www.msssi.gob.es/ssi/familiasInfancia/ inclusionSocial/docs/PlanNacionalAccionInclusionSocial_2013_2016.pdf. Acceso en: 3 mar. 2015.

NAVARRO, V. Ataque a la democracia y al bienestar: crítica al pensamiento económico dominante. Barcelona: Anagrama, 2015.

OCDE. Estudios económicos de la OCDE: España. Paris, 2014. Disponible en: http://www.oecd.org/economy/surveys/Spain-Overview-Spanish.pdf. Acceso en: 3 mar. 2015.

PAKULSKI, J.; WALTERS, M. The Death of Class. Londres: Sage Publications, 1996.

PAUGAM, S. La disqualification sociale: essai sur la nouvelle pauvreté. Paris: PUF, 2000.

POPPENDIECK, J. Sweet Charity?: emergency food and the end of entitlement. Londres: Penguin Books, 1998.

POULAIN, J. P. Manger Aujourd'hui: attitudes, normes et pratiques. Paris: Ed. Privat, 2002.

RICHES, G.; SILVASTI, T. (ed.). First world hunger revisited. Londres: Palgrave Macmillan, 2014.

SUTTON, D. Secrets from the Greek Kitchen: cooking, skill, and everyday life on an Aegean Island. California: University Of California Press, 2014.

WARDE, A. Consumption, food and taste: culinary anatomies and commodity culture. Londres: Sage Publications, 1997. 



\section{Sobre os autores}

\section{CHRISTIANE AYUMI KUWAE}

Doutora em Alimentação, Nutrição e Saúde e integrante do Núcleo de Estudos sobre Cultura e Alimentação (Nectar) do Instituto de Nutrição da Universidade do Estado do Rio de Janeiro (UERJ).

\section{DINA CZERESNIA}

Doutora em Saúde Pública. Professora titular no Departamento de Epidemiologia e Métodos Quantitativos em Saúde, Escola Nacional de Saúde Pública Sergio Arouca, Fundação Oswaldo Cruz (Fiocruz), Rio de Janeiro.

\section{DANIELA MENEZES NEIVA BARCELLOS}

Doutora em Alimentação, Nutrição e Saúde e integrante do Núcleo de Estudos sobre Cultura e Alimentação (Nectar) do Instituto de Nutrição 
da Universidade do Estado do Rio de Janeiro (UERJ) e pesquisadora do Laboratório Digital de Educação Escolar (LADIG'E) do Instituto de Nutrição Josué de Castro da Universidade Federal do Rio de Janeiro (UFRJ), Brasil.

\section{DENISE DA COSTA OLIVEIRA SIQUEIRA}

Doutora em Ciências da Comunicação pela Escola de Comunicações e Artes da Universidade de São Paulo (USP), com estágio pós-doutoral em Sociologia na Université Paris-Descartes. Professora titular do Programa de Pós-graduação em Comunicação e coordenadora do Laboratório de Pesquisa em Comunicação, Interação e Cultura (Lampe) da Faculdade de Comunicação Social da Universidade do Estado do Rio de Janeiro (UERJ).

\section{DIANA CRIS MACEDO RODRIGUES}

Mestre em Saúde Pública pela Universidade Federal do Ceará (UFC). Doutoranda em Alimentos, Nutrição e Saúde e integrante do Núcleo de Estudos e Pesquisas em Alimentação e Cultura (Nepac) da Universidade Federal da Bahia (UFBA).

\section{DIEGO MARINHO CALABRESE}

Mestrando em Alimentos, Nutrição e Saúde e integrante do Núcleo de Estudos e Pesquisas em Alimentação e Cultura (Nepac) da Universidade Federal da Bahia (UFBA).

\section{ELIANE PORTES VARGAS}

Doutora em Saúde Coletiva pelo Instituto de Medicina Social da Universidade do Estado do Rio de Janeiro (UERJ). Docente e pesquisadora titular do Programa de Pós-Graduação em Ensino em Biociências e Saúde do Instituto Oswaldo Cruz da Fundação Oswaldo Cruz (Fiocruz). Líder do grupo de pesquisa Estudos Socioculturais sobre Corpo, Gênero, 
Reprodução e Sexualidade (Corpus) da Universidade Federal Rural do Rio de Janeiro (UFRRJ) e pesquisadora do Núcleo de Estudos sobre Cultura e Alimentação (Nectar), do Instituto de Nutrição da UERJ.

\section{FRANCISCO ROMÃO FERREIRA}

Doutor em Ciências pela Escola Nacional de Saúde Pública, com pós-doutorado em Ensino de Biociências na Saúde pela Fundação Oswaldo Cruz (Fiocruz). Professor adjunto no Programa de Pós-Graduação em Alimentação, Nutrição e Saúde e integrante do Núcleo de Estudos sobre Cultura e Alimentação (Nectar) do Instituto de Nutrição da UERJ.

\section{IGOR SACRAMENTO}

Doutor em Comunicação e Cultura pela Universidade Federal do Rio de Janeiro (UFRJ). Pesquisador do Laboratório de Pesquisa em Comunicação e Saúde (Laces) do Instituto de Comunicação e Informação Científica e Tecnológica em Saúde da Fundação Oswaldo Cruz (Fiocruz) e docente do Programa de Pós-Graduação em Comunicação e Cultura da UFRJ.

\section{ISABELA MAGALHÃES BOSI}

Graduada em Comunicação Social (Jornalismo) pela Universidade Federal do Ceará (UFC) e mestre em Memória Social, na linha de pesquisa Memória e Linguagem, pela Universidade Federal do Estado do Rio de Janeiro (Unirio).

\section{JÁDER FERREIRA LEITE}

Doutor em Psicologia Social. Professor associado no Programa de Pós-Graduação e Psicologia da Universidade Federal do Rio Grande do Norte (UFRN). 


\section{LIGIA AMPARO-SANTOS}

Doutora em Ciências Sociais pela Pontifícia Universidade Católica de São Paulo (PUC-SP). Docente no Programa de Pós-Graduação em Alimentos, Nutrição e Saúde e coordenadora do Núcleo de Estudos sobre Cultura e Alimentação (Nectar) da Escola de Nutrição da Universidade Federal da Bahia (UFBA).

\section{LUIS ANTONIO DOS SANTOS BAPTISTA}

Doutor em Psicologia Escolar pela Universidade de São Paulo (USP) com pós-doutorado na Faculdade de Sociologia da Universidade de Roma La Sapienza. Professor titular do Instituto de Psicologia e do Programa de Pós-Graduação em Psicologia da Universidade Federal Fluminense (UFF). Professor do Programa de Pós-Graduação em Psicologia Social e Institucional da Universidade Federal do Espírito Santo (UFES).

\section{LUISA FERREIRA DA SILVA}

Doutora em Ciências Sociais na L'Ecole des Hautes Etudes en Sciences Sociales, Paris. Pesquisadora da linha de estudos Saúde, Comunicação e Cultura do Centro de Administração e Políticas Públicas do Instituto Superior de Ciências Sociais e Políticas da Universidade de Lisboa, Portugal.

\section{MABEL GRACIA-ARNAIZ}

Doutora em Geografia e História pela Universidade de Barcelona. Professora titular no Programa de Doutorado em Antropologia Social e pesquisadora do Medical Anthropology Research Center e do Departament d'Antropologia, Filosofia i Treball Social da Universitat Rovira i Virgili, Espanha. 


\section{MAGDA DIMENSTEIN}

Doutora em Saúde Mental pela Universidade Federal do Estado do Rio de Janeiro (Unirio), Professora titular no Programa de Pós-Graduação em Psicologia e líder do grupo de pesquisa Modos de subjetivação, Políticas Públicas e Contextos de Vulnerabilidades da Universidade Federal do Rio Grande do Norte (UFRN).

\section{MARIA CLÁUDIA DA VEIGA SOARES DE CARVALHO}

Doutora em Saúde Coletiva pelo Instituto de Medicina Social da Universidade do Estado do Rio de Janeiro (UERJ). Professora adjunta do Instituto Josué de Castro de Nutrição da Universidade Federal do Rio de Janeiro (UFRJ), docente do Programa de Pós-Graduação em Alimentação, Nutrição e Saúde e pesquisadora do Núcleo de Estudos sobre Cultura e Alimentação (Nectar) do Instituto de Nutrição da UERJ.

\section{MARIA DA GRAÇA COSTA}

Doutoranda em Psicologia e integrante do grupo de pesquisa Modos de Subjetivação, Políticas Públicas e Contextos de Vulnerabilidades da Universidade Federal do Rio Grande do Norte (UFRN).

\section{MARIA LUCIA MAGALHÃES BOSI}

Doutora em Saúde Pública pela Fundação Oswaldo Cruz (Fiocruz) com pós-doutorado na Universidade de Toronto. Professora titular no Programa de Pós-Graduação em Saúde Coletiva e pesquisadora líder do Laboratório de Avaliação e Pesquisa Qualitativa em Saúde (LAPQS) da Universidade Federal do Ceará (UFC). 


\section{MARIANNE CELKA}

Doutora em Sociologia, professora e pesquisadora no Instituto de Pesquisas Sociológicas e Antropológicas do Centro de Pesquisas Imaginárias da Universidade Paul-Valéry de Montpellier, França.

\section{TATIANA COURA OLIVEIRA}

Doutora em Ciências na área de Epidemiologia em Saúde Pública pela Escola Nacional de Saúde Pública Sérgio Arouca da Fundação Oswaldo Cruz (Fiocruz). Docente do Instituto de Ciências Biológicas e da Saúde da Universidade Federal de Viçosa (UFV).

\section{SHIRLEY DONIZETE PRADO}

Doutora em Saúde Coletiva pelo Instituto de Medicina Social da Universidade do Estado do Rio de Janeiro (UERJ). Professora titular no Programa de Pós-Graduação em Alimentação, Nutrição e Saúde e pesquisadora líder do Núcleo de Estudos sobre Cultura e Alimentação (Nectar), do Instituto de Nutrição da UERJ. 
$\mathrm{E}$

ste livro foi produzido em formato 170 x $240 \mathrm{~mm}$ e utiliza as tipografias FS Brabo e Poligon, com miolo com miolo impresso na Edufba, em papel Alta Alvura $75 \mathrm{~g} / \mathrm{m}^{2}$ e capa em Cartão Supremo $300 \mathrm{~g} / \mathrm{m}^{2}$, impressa na Gráfica 3.

Tiragem: 400 exemplares. 